JULIANA CAROLINE DE ALENCAR DA SILVA

RECUPERAÇÃO DE CÓRREGOS URBANOS ATRAVÉS DO CONTROLE DE CARGAS PONTUAIS E DIFUSAS. ESTUDO DE CASO: CÓRREGO IBIRAPORÃ E DO SAPÉ.

São Paulo

2014

Av. Prof. Almeida Prado, trav. 2, n 271 -Cidade Universitária - Butantã CEP. 05508-900 - São Paulo - Capital

Tel.: 3091-5444 Fax: 3091-5423 
JULIANA CAROLINE DE ALENCAR DA SILVA

\section{RECUPERAÇÃO DE CÓRREGOS URBANOS ATRAVÉS DO CONTROLE DE CARGAS PONTUAIS E DIFUSAS. ESTUDO DE CASO: CÓRREGO IBIRAPORÃ E DO SAPÉ.}

Dissertação de Mestrado apresentada à Escola Politécnica da Universidade de São Paulo para obtenção do título de Mestre em Engenharia Civil.

Área de Concentração: Engenharia Hidráulica e Sanitária

Orientadora: Prof ${ }^{\mathrm{a}}$ Titular $\mathrm{Dr}^{\mathrm{a}}$ Monica Ferreira do Amaral Porto.

São Paulo

2014 
Este exemplar foi revisado e alterado em relação à versão original, sob responsabilidade única do autor e com a anuência de seu orientador.

São Paulo 31 de janeiro de 2014

Assinatura do autor

Assinatura do orientador

FICHA CATALOGRÁFICA

Silva, Juliana Caroline de Alencar da

Recuperação de córregos urbanos através do controle de cargas pontuais e difusas - estudo de caso : córrego lbiraporã e do Sapé / J.C.A. da Silva. -- São Paulo, 2014.

$192 \mathrm{p}$.

Dissertação (Mestrado) - Escola Politécnica da Universidade de São Paulo. Departamento de Engenharia Hidráulica e Ambiental.

1. Hidrologia urbana 2. Córregos urbanos (Recuperação) I. Universidade de São Paulo. Escola Politécnica. Departamento de Engenharia Hidráulica e Ambiental II. t. 


\section{AGRADECIMENTOS}

Esta dissertação é o resultado de uma jornada de trabalho que só foi possível graças à colaboração direta e indireta de diversas pessoas, as quais merecem ser lembras aqui neste breve agradecimento.

Agradeço em primeiro lugar à minha orientadora Monica Porto que ao longo desta jornada contribui de inúmeras maneiras para meu amadurecimento acadêmico. Obrigada pelas conversas, pelos conhecimentos passados, pelo investimento e pela confiança. Sem dúvida é um orgulho ter tido a oportunidade de ser sua orientanda neste trabalho.

À professora Ana Lúcia Brandimarte que gentilmente me acolheu junto à sua equipe e disponibilizou-me um espaço no laboratório de ecologia aquática do Instituto de Biociências para que eu pudesse desenvolver a parte relativa a indicadores biológicos. No laboratório conheci profissionais extremamente competentes e prestativos (Daniel Bispo e Fernanda Lage) que me auxiliaram muito, tornando meu trabalho muito produtivo e agradável. Um agradecimento especial à Fernanda Lage pelos conhecimentos compartilhados e pela amizade construída ao longo da nossa jornada conjunta no laboratório.

À Andreia Sandrini, coordenadora do programa "Córrego Limpo" na zona oeste, que não poupou esforços para me munir dos dados necessários para embasar este estudo.

Ao professor Rodolfo Scarati que solicitamente me auxiliou na obtenção dos instrumentos necessários para realização das análises físico-químicas utilizadas neste estudo.

À minha mãe e irmãos que a cada olhar orgulhoso dos meus feitos me enchem de força para ir atrás de todos os meus sonhos. Com especial menção à minha irmãzinha Daniela que é meu orgulho... Ela me faz ter esperança em um futuro melhor.

E por fim ao meu marido Julio, que participou deste processo das mais diversas formas possíveis, seja me acompanhando e ajudando nas coletas ou sendo compreensível nos momentos em que deixei de estar com ele para me dedicar a esta pesquisa. Obrigada por compartilhar comigo mais essa conquista. Sem você nada faria sentido. 


\section{RESUMO}

Com a consolidação do saneamento em algumas bacias urbanas, um novo desafio surge: o da recuperação dos corpos d'água. $O$ que a principio parece ser uma consequência do processo, na realidade se mostra uma tarefa muito mais complexa e que envolve diversos fatores, tornando o processo de recuperação lento e dispendioso. Muito se diz a respeito da despoluição dos corpos d'água através da eliminação da carga pontual, mas o que se observa na prática é que, mesmo diante do controle das cargas pontuais, os corpos d'água continuam poluídos devido às cargas difusas. A preocupação com a poluição por carga difusa já é um assunto muito estudado em locais onde a poluição por cargas pontuais já possui um controle efetivo, mas este assunto ainda é um grande desafio em países como o Brasil, onde o controle da carga pontual ainda não constitui uma realidade palpável. Atualmente, na região metropolitana de São Paulo, há diversos programas atuando na despoluição de corpos d'água através do controle de cargas pontuais, dentre eles o programa "Córrego Limpo" se destaca por agir na otimização de sistemas de esgotamento sanitário, e apesar dos bons resultados obtidos, como o programa se baseia no controle de cargas pontuais, estas bacias não se encontram completamente despoluídas. Considerando o caso brasileiro, o programa é pioneiro no que se refere à adoção de medidas que integram a população no processo de recuperação, pois implanta em algumas de suas bacias um programa de governança colaborativa, que, através da mobilização da população, promove a integração desta com o corpo d'água. Diante deste panorama, o presente estudo, tem como intuito, através da análise de córregos de interesse do programa "Córrego Limpo", contribuir para a melhor compreensão dos desafios envolvidos no processo de recuperação de corpos d'água urbanos através do controle de cargas pontuais e difusas. No estudo empregou-se o método da Unidade de carga para quantificação da geração de cargas difusas nas bacias e identificação do seu potencial poluidor, resultando na criação de um índice de qualidade da superfície da bacia; Avaliou-se também a qualidade ambiental destes corpos d'água através de indicadores físicos, químicos e biológicos, o que revelou a importância do uso conjunto destes indicadores, já que obteve-se resultados distintos para cada um destes indicadores; com base nos resultados obtidos nestes estudos foi possível avaliar o quão complexo é o processo de recuperação de corpos d'água em áreas urbanas.

PALAVRAS-CHAVE: Recuperação de córregos urbanos, qualidade da água no meio urbano, poluição difusa, recursos hídricos, córregos urbanos. 


\begin{abstract}
With the consolidation of sanitation in some urban watersheds, a new challenge arises: the recovery of bodies of water. What at first appears to be a consequence of the process, in fact it shows to be a much more complex task and involves several facts, making the recovery process slow and costly. Much is said about the remediation of water bodies by removing point charge, but what we notice in practice is that even after controlling of point charge, they remain polluted because nonpoint pollution. The concern with nonpoint pollution is much studied in places where pollution by point charge already has an effective control, but this issue is still a challenge in countries like Brazil, where the control point charge does not constitutes a tangible reality. Currently, the São Paulo metropolitan area there are several programs working on recovering of water bodies through the control of point charge, including the "Córrego Limpo" that acts optimizing sewage systems, and is notorious the improvement in the quality of water bodies covered its actions. However, as the program based on controling of point charge, the streams are not completely unpolluted. Considering the Brazilian case, the program is a pioneer when it comes to the adoption of measures that integrate the population in the recovering process. It deploys in some watersheds a program of collaborative governance that, through the people mobilization, promotes the body of water, resulting in reduction of the potential pollution in the watersheds and rendering more effective the process. The present study has the intention, through the analysis of streams of interest to the program "Córrego Limpo", contribute to a better understanding of the challenges involved in the recovery process of urban water bodies through the control of the point and nonpoint pollution. In the study was used the method of unit load to quantify the generation of diffuse loads in basins and identification of their pollution potential, resulting in the creation of an index of quality of the surface of the basin, also evaluated the environmental quality of these bodies of water through physical, chemical and biological indicators, which revealed the importance of the combined use of these indicators, since we obtained different results for each of these indicators, the results of this study showed how complex is the recovery process of water bodies in urban areas.
\end{abstract}

KEYWORDS: Restoration of urban streams, water quality in urban watersheds, nonpoint pollution, water resources, urban streams. 


\section{LISTA DE ILUSTRAÇÕES}

Ilustração 01- População Rural e Urbana no Brasil. Fonte: Adaptado de ANA (2012).

llustração 02- Acesso à água potável na Etiópia, Jordânia, Nicarágua, Nigéria, e Tajiquistão, entre 2004 e 2005 e a previsão do acesso em 2015. Fonte: Adaptado de Bain et al. (2012).

llustração 03- Acesso à água potável no Brasil (Área urbana) em 1992 e 2007. Fonte: Elaborado pela autora a partir de IBGE (s/d).

Ilustração 04- Favela do Sapé - Saída das instalações prediais de esgotos sanitários das moradias localizadas nas margens do Córrego do Sapé. Fonte: Cortesia de Andréia Sandrini - Coordenadora das ações do programa "Córrego Limpo" na Zona Oeste.

llustração 05- Situação dos corpos d'água monitorados em 2010 - Fonte: Adaptado de ANA (2012).

llustração 06- Esquema mostrando o uso do Parque Linear como instrumento de prevenção a enchentes. Fonte: Elaborado pela autora.

Ilustração 07- Figura A: Vista Geral da área do Parque linear Várzeas do Tietê. Figura B: Núcleo Jd. Helena - São Paulo. Figura C: Núcleo Any Jaci - Guarulhos. Fonte: DAEE (s/d).

llustração 08- Figura A: Projeto Urbanístico de um dos trechos do canal. Figura B: Equipamentos públicos e calçadas permeáveis ao longo do canal. Fonte: PMSP $(\mathrm{s} / \mathrm{d})$.

llustração 09- Parque Linear Canivetes. Foto A: Vista antes das obras de intervenção. Foto $B, C$ e D: Evolução das obras de intervenção para criação do parque linear. Foto E: Parque linear Canivetes concluído - Fonte: Fotos A e B: http://www.znnalinha.com.br/brasilandia/html/linear.html; Fotos 9C e 9D: http://www. panoramio.com/photo/25257058; Foto E: ANMMA (2011). 
llustração 10- Córrego Carajás - Antes (Foto A) e Depois (Foto B) das obras de intervenção do programa "Córrego Limpo". Fonte: Cortesia de Gilmar Massone SABESP.

llustração 11- Evolução da DBO5-20 no Córrego Carajás. Fonte: Adaptado de Córrego Limpo (s/d). 39

llustração 12- Principais grupos taxonômicos do fitoplâncton encontrados em ambientes aquáticos continentais. Fonte: Adaptado de Esteves (1998).

llustração 13- Principais grupos taxonômicos do zooplâncton encontrados em ambientes aquáticos continentais. Fonte: Adaptado de Esteves (1998). 50

llustração 14- Principais grupos taxonômicos bentônicos encontrados em ambientes aquáticos continentais. Fonte: Adaptado de Esteves (1998).

llustração 15- Principais morfotipos da larva Chironomidae. Fonte: Strixino (2011).

llustração 16- Ciclo de vida da larva Chironomidae. Fonte: Strixino (2011). 54

Ilustração 17- Fontes de Poluição no Meio Urbano. Fonte: Elaborado pela autora a partir de WALESH (1989).

llustração 18- Medidas estruturais - Trincheiras de Infiltração: Foto A: Detalhe construtivo de uma trincheira de infiltração (Adaptado pela autora de SOUZA, 2002). Fotos B e C: Trincheiras de infiltração implantadas (UFSM, s/d).

Ilustração 19- Medidas estruturais - Filtro Grama e Wet Ponds: Foto A: Estruturas de retenção e detenção em um rio na zona agrícola de Ohio-EUA (MDA, s/d). Foto B: Filtro Grama (MDA, s/d). Foto C: Wet Ponds (DNREC, s/d). Foto D: Wet Ponds (Adaptado pela autora de USEPA, s/d).

Ilustração 20- Ilustração Simplificada do efeito de redução da carga de poluição no escoamento provocado pela varrição - Fonte: Adaptado de Novotny et al. (1985). . 63 
llustração 21- Metodologia de aplicação do método da Unidade de Carga. Fonte: Elaborado pela autora.

Ilustração 22- Córrego do Sapé e Córrego Ibiraporã - Localização e acesso. Fonte: Elaborado pela autora.

Ilustração 23- Córrego do Sapé: Bacia contribuinte. Fonte: Elaborado pela autora.

llustração 24- Nascente do Sapé: Detalhe do canal em 12/08/2008 (Foto A) e em 17/02/2012 (Foto B). Fonte: Cortesia de Andréia Sandrini - Coordenadora das ações do programa "Córrego Limpo" na Zona Oeste. 69

llustração 25- Nascente do Sapé: Detalhe da Seção do córrego antes e depois da canalização. Fonte: Elaborado pela autora.

llustração 26- Nascente do Sapé: Fotos A e B: Detalhe da desembocadura da travessia da Rodovia Raposo Tavares e detalhe da característica visual das águas da nascente em 13/08/2008. Fonte: Cortesia de Andréia Sandrini - Coordenadora das ações do programa "Córrego Limpo" na Zona Oeste. Fotos C, D e E: Detalhe da desembocadura da travessia da Rodovia Raposo Tavares e detalhe da característica visual das águas da nascente em 08/02/2012. Fonte: Fotos da autora. .70

llustração 27- Nascente do Sapé: Acumulo de resíduos sólidos no Canal antes (Foto A) e depois (Foto B) de um evento de chuva. Fonte: Fotos da autora. .71

llustração 28- Nascente do Sapé: Foto A: Detalhe da canaleta marginal ao canal. Foto B: Visão geral do canal. Foto C: Detalhe do Fundo do Canal em gabião. Fotos D: Detalhes dos lançamentos no canal de nascentes da região através de galerias de águas pluviais (GAP's). Fonte: Fotos da autora. 72

llustração 29- Nascente do Sapé: Foto A, B, C e D: Condição do canal em 06/06/2013 nas estacas 30, 27 e 28 e 26 respectivamente. Fonte: Fotos da autora.

llustração 30- Parque Linear 28 - Trecho 1: Sequência de fotos mostrando as obras do sistema de drenagem da bacia (Foto A) e as obras de implantação das áreas de 
lazer (Foto B, C e D). Fonte: Cortesia de Andréia Sandrini - Coordenadora das ações do programa "Córrego Limpo" na Zona Oeste.

llustração 31- Parque Linear 28 - Trecho 1: Sequência de fotos, obtidas em 06/06/2013, mostrando o parque linear atualmente. Fonte: Fotos da autora. 75

llustração 32- Parque Linear 28 - Trecho 2: Concepção do parque linear. Fonte: Elaborado pela autora.

llustração 33- Parque Linear 28 - Trecho 2: Sequência de fotos mostrando o canal antes das obras de intervenção (Fotos $A$ e B) e a evolução das primeiras intervenções para implantação do parque (Fotos $C$ e D). Fonte: Cortesia de Andréia Sandrini - Coordenadora das ações do programa "Córrego Limpo" na Zona Oeste.77 llustração 34- Parque Linear 28 - Trecho 2: Evolução das obras de canalização do córrego - Fotos A e B, obtidas em 27/10/2011 e 01/12/2011 respectivamente - Fonte: Cortesia de Andréia Sandrini - Coordenadora das ações do programa "Córrego Limpo" na Zona Oeste; e Foto C obtida em 04/01/2013 - Fonte: Foto da autora. ....78

llustração 35- Parque Linear 28 - Trecho 2: Conclusão das obras de canalização do córrego (Fotos A e B). Fonte: Fotos da autora.

llustração 36- Parque Linear 28 - Trecho 2: Evolução das obras para implantação dos conjuntos habitacionais - Foto A e B obtidas em 04/01/2013 e 06/06/2013 respectivamente na estaca 8 e Foto $C$ obtida em 06/06/2013 na estaca 20. Fonte: Fotos da autora. 79

Ilustração 37- Córrego Ibiraporã: Bacias Contribuintes. Fonte: Elaborado pela autora. .80

llustração 38- Córrego Ibiraporã: Estaca 8 - Antes (Foto A) e depois (Foto B) das intervenções do programa. Fonte: Cortesia de Andréia Sandrini - Coordenadora das ações do programa "Córrego Limpo" na Zona Oeste.

llustração 39- Córrego Ibiraporã: Estaca 13 - Antes (Foto A) e Estaca 9 - depois (Foto B) das intervenções do programa. Fonte: Cortesia de Andréia Sandrini Coordenadora das ações do programa "Córrego Limpo" na Zona Oeste. 
llustração 40- Córrego lbiraporã: Estaca 7 - Travessia da rede de esgotos pública sobre o canal (Foto A) e Estaca 6 - Lançamento irregular de esgotos (Foto B e C). Fonte: Fotos da autora.

Ilustração 41- Córrego Ibiraporã: Heterogeneidade do canal com relação ao tratamento de suas margens, fundo e a vegetação presente. Fonte: Fotos da autora.

llustração 42- Córrego Ibiraporã: Estaca 16 - Antes (Foto A) e depois (Foto B). Fonte: Fotos da autora.

llustração 43- Revestimentos flexíveis. Fonte: Adaptado de Brighetti et al.(1999).

llustração 44- Proteções rígidas. Fonte: Fonte: Adaptado de Brighetti et al.(1999).

llustração 45- Relação entre a Precipitação $(\mathrm{mm})$ e a Demanda Bioquímica de Oxigênio (DBO) no período de 01/01/2007 a 01/01/2012 nos córregos da Zona Oeste pertencentes ao programa "Córrego Limpo". Fonte: Elaborado pela autora a partir de Córrego Limpo (s/d) e SAISP (2012).

llustração 46- Relação entre a Precipitação $(\mathrm{mm})$ e a Demanda Bioquímica de Oxigênio (DBO) na Nascente do Sapé no período 01/01/2007 a 01/01/2012. Fonte: Elaborado pela autora a partir de Córrego Limpo (s/d) e SAISP (2012). .97

llustração 47- Relação entre a Precipitação $(\mathrm{mm})$ e a Demanda Bioquímica de Oxigênio (DBO) no Córrego Ibiraporã no período 01/01/2007 a 01/01/2012. Fonte: Elaborado pela autora a partir de Córrego Limpo (s/d) e SAISP (2012). .99 llustração 48- DBO do Rio Tietê no período de agosto de 2007 a dezembro de 2009. Fonte: Porto (s/d). 102

llustração 49- DBO do Rio Pinheiros no período de agosto de 2007 a dezembro de 2009. Fonte: Porto (s/d). 102

Ilustração 50- DBO do Córrego Ibiraporã em 2011. Fonte: Elaborado pela autora a partir de Córrego Limpo (s/d) e CONAMA 357 (2005). 
llustração 51- Nascente do Sapé: Pontos de coleta para avaliação física e química da qualidade da água. Fonte: Elaborado pela autora

Ilustração 52- Córrego Ibiraporã: Pontos de coleta para avaliação física e química da qualidade da água. Fonte: Elaborado pela autora

llustração 53- Córrego Ibiraporã: Coleta de amostras de água para análises físicas de químicas. Fonte: Fotos da autora.

llustração 54- Distribuição na bacia da Nascente do Sapé das classes de uso do solo do Corine Land Cover (CLC). Fonte: Elaborado pela autora.

llustração 55- Distribuição na bacia do Córrego Ibiraporã das classes de uso do solo do Corine Land Cover (CLC). Fonte: Elaborado pela autora.

llustração 56- Evolução da qualidade da superfície do solo em uma bacia hipotética. Fonte: Elaborado pela autora. 120

llustração 57- Utilização do amostrador tipo Surber (Foto A). Amostrador tipo Surber Comercial. (Foto B). Fonte: ASLO (s/d) por Ray Drenner. 122 Ilustração 58- Córrego Ibiraporã: Pontos de Coleta dos organismos bentônicos. Fonte: Elaborado pela autora. 123 Ilustração 59- Córrego Ibiraporã: Coleta das amostras. Fonte: Fotos da autora. 124

Ilustração 60- Córrego Ibiraporã: Preparo das amostras para triagem. Fonte: Fotos da autora. 125

llustração 61- Armadilhas com substrato para coleta de macroinvertebrados bentônicos - Foto A e B. Fonte: Fotos da autora. 126

llustração 62- Fotos A e B: Preparo das armadilhas biológicas. Foto C e D: Armadilhas biológicas instaladas na Nascente do Sapé. Fonte: Fotos da autora...127

llustração 63- Figura A: Esquema da vista dorsal de uma ninfa de Ephemeroptera Fonte: Modificada de Mariano/ Froehlich (2007) e Figura B: Foto de uma ninfa de Ephemeroptera - Fonte: Clickciência (2009). 
llustração 64- Figura A: Esquema Geral de uma ninfa de Plecoptera - Fonte: Modificada de Lecci et al. (2007) e Figura B: Ninfa de Plecoptera - Fonte: Böhringer, Friedrich.

llustração 65- Figura A: Esquema Geral de uma Larva de Trichoptera - Fonte: Modificada de Calor (2007) e Figura B: Foto de Larva de Trichoptera - Fonte: USEPA (s/d). 134 llustração 66- Organismos presentes nas amostras. Fonte: Fotos da autora. 138

llustração 67- DBO do Córrego Ibiraporã e sua classificação segundo "Córrego Limpo". Fonte: Elaborado pela autora. 141

Ilustração 68- DBO do Córrego Ibiraporã e sua classificação segundo Índice Biótico de Família de Hilsenhoff. Fonte: Elaborado pela autora. 141 


\section{LISTA DE TABELAS}

Tabela 01 -Evolução do programa "100 Parques". Fonte: Adaptado de ANMMA (2011).

Tabela 02 -Resumo das fases do programa "Córrego Limpo". Fonte: Elaborado pela autora a partir de informações cedidas pelo programa "Córrego Limpo". 40

Tabela 03 -Resumo das características das classes de qualidade das águas. Fonte: Elaborado pela autora a partir de CONAMA (2005).

Tabela 04 -Variáveis de qualidade das águas. Fonte: Elaborado pela autora a partir de CETESB (s/d).

Tabela 04 - Variáveis de qualidade das águas. Fonte: Elaborado pela autora a partir de CETESB (s/d). (Continuação).

Tabela 05 -Características das principais variáveis para a determinação da qualidade da água - Fonte: Adaptado de Nascimento (2011)

Tabela 06 -Matriz de coeficientes de exportação de cargas. Fonte: Adaptado de SMA/Prime Engenharia (1998). .64

Tabela 07 -Matriz de coeficientes de exportação de cargas difusas. Fonte: Adaptado de Steinke (2007). .65

Tabela 08 -Tratamento das margens e fundo dos corpos d'água em estudo. Fonte: Elaborado pela autora. 88

Tabela 09 -Caracterização dos Córregos em função da DBO. Fonte: Adaptado de Córrego Limpo (s/d).

Tabela 10 -Dados base para aplicação do teste $T$ para avaliação da eficiência do programa na redução da DBO nos corpos d'água em questão. Fonte: Elaborado pela autora 95

Tabela 11 -Coeficientes de relação de Pearson obtidos para os córregos da zona oeste. Fonte: Elaborado pela autora. 
Tabela 12 -Concentração média estimada de poluentes por tipologia - Fonte: Adaptado pela autora de Lima (1998) e Larentis (2004).

Tabela 13 -DBO5, 20 no período anterior às intervenções do programa e após a conclusão das intervenções do programa para os córregos Ibiraporã e Nascente do Sapé. Fonte: Elaborado pela autora. 100

Tabela 14 -Coeficientes de relação de Pearson obtidos para os córregos Ibiraporã e Nascente do Sapé da zona oeste. Fonte: Elaborado pela autora. 101

Tabela 15 -Concentração média estimada para poluição difusa (Adaptado de Larentis, 2004). Fonte: Elaborado pela autora. 103

Tabela 16 -DBO para diferentes classes de corpos d'água de água doce. Fonte: Elaborado pela autora a partir da CONAMA 357 (2005). 103

Tabela 17 -Nascente do Sapé: Variáveis físicas e químicas da água - Período chuvoso. Fonte: Elaborado pela autora. 107

Tabela 18 -Postos obtidos para as variáveis físicas e químicas - Nascente do Sapé. Fonte: Elaborado pela autora. 108

Tabela 19 -Teste de Friedman - Nascente do Sapé. Fonte: Elaborado pela autora. 108

Tabela 20 -Córrego Ibiraporã: Monitoramento das variáveis físicas e químicas da água. Fonte: Elaborado pela autora. 109

Tabela 20 - Córrego Ibiraporã: Monitoramento das variáveis físicas e químicas da água. Fonte: Elaborado pela autora. (Continuação)

Tabela 21 -Postos obtidos para as variáveis físicas e químicas da água- Córrego Ibiraporã. Fonte: Elaborado pela autora.

Tabela 22 -Teste de Friedman - Córrego Ibiraporã. Fonte: Elaborado pela autora.

Tabela 23 -Produção de carga difusa para classes de uso do solo do Corine Land Cover (CLC). Fonte: Adaptado de Cecchi et al. (2007) 
Tabela 24 -Produção de carga difusa para tecido urbano. Fonte: Adaptado de Steinke (2007).

Tabela 25 -Produção de Poluição Difusa para classes de uso do solo. Fonte: Elaborado pela autora.

Tabela 26 -Produção de carga difusa para as diferentes parcelas de classe de uso do solo na bacia da Nascente do Sapé, calculada pelo método da Unidade de Carga. Fonte: Elaborado pela autora.

Tabela 27 -Produção de carga difusa para as diferentes parcelas de classe de uso do solo na bacia do Córrego Ibiraporã, calculada pelo método da Unidade de Carga. Fonte: Elaborado pela autora.

Tabela 28 -Classificação das Chuvas. Fonte: Adaptado de Reichardt (1987).

Tabela 29 -Intensidade de chuva para remoção do material particulado depositado sobre superfícies impermeáveis. Fonte: Adaptado de USEPA (1986).

Tabela 30 -Acumulo de carga difusa na superfície da bacia - Nascente do Sapé. Fonte: Elaborado pela autora.

Tabela 31 -Acumulo de carga difusa na superfície da bacia - Córrego Ibiraporã. Fonte: Elaborado pela autora.

Tabela 32 -Índice de qualidade da superfície da bacia. Fonte: Elaborado pela autora.

Tabela 33 -Classificação de canais segundo Strahler (1952) e Horton (1945). Fonte: Adaptado de Strahler (1952) e Horton (1945). 122

Tabela 34 -Tolerância à poluição orgânica segundo o Índice Biótico de Famílias de Hilsenhoff. Fonte: Elaborado pela autora a partir de Ferreiro (2007). 130

Tabela 35 -Qualidade da água segundo o Índice Biótico de Famílias de Hilsenhoff. Fonte: Ferreiro (2007). 131 
Tabela 36 - Abundância dos organismos bentônicos - Inverno. Fonte: Elaborado pela autora. 136

Tabela 37 - Abundância dos organismos bentônicos - Verão. Fonte: Elaborado pela autora.

Tabela 38 -Resultados obtidos - Índices Biológicos: Córrego Ibiraporã. Fonte: Elaborado pela autora. 139

Tabela 39 -Resultados obtidos - Índice Biótico de Família de Hilsenhoff: Córrego Ibiraporã. Fonte: Elaborado pela autora. 140 


\section{LISTA DE ABREVIATURAS E SIGLAS}

ANA Agência Nacional de Águas

ANMMA Associação Nacional de Órgãos Municipais de Meio Ambiente

APP Área de Proteção Permanente

BMP Best Management Practices

CETESB Companhia de Tecnologia de Saneamento Ambiental

CME Concentração Média de Evento

CONAMA Conselho Nacional do Meio Ambiente

COV Compostos Orgânicos Voláteis

DAEE Departamento de Águas e Energia Elétrica

DBO Demanda Bioquímica de Oxigênio

H' Diversidade Biológica

D Dominância Biológica

DQO Demanda Química de Oxigênio

E Equitabilidade Biológica

EPT Ephemeroptera, Plecoptera e Trichoptera

IBGE Instituto Brasileiro de Geografia e Estatística

MNAC Modelo dos Níveis de Ação Colaborativa

OD Oxigênio Dissolvido

OMS Organização Mundial da Saúde

PMSP Prefeitura do Município de São Paulo

PNUD Programa das Nações Unidas para o Desenvolvimento

S Riqueza Biológica

SABESP Companhia de Saneamento Básico do Estado de São Paulo

SEHAB Secretaria de Habitação do Município de São Paulo

SDT Sólidos Dissolvidos Totais

$\mathrm{Tr} \quad$ Tempo ou Período de Retorno

UC Unidade de Carga

UNICEF Fundo das Nações Unidas para a Infância

USEPA United States Environmental Protection Agency 


\section{SUMÁRIO}

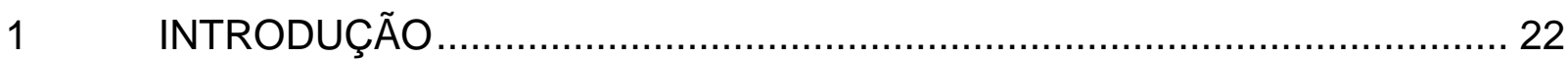

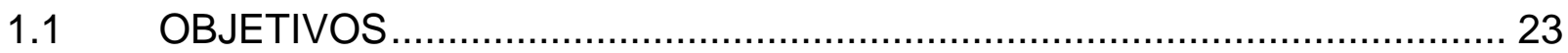

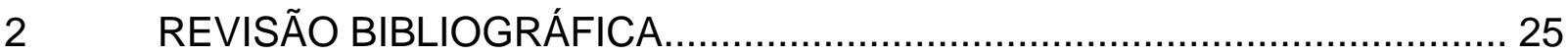

2.1 CRESCIMENTO POPULACIONAL E A OCUPAÇÃO DO SOLO ................. 25

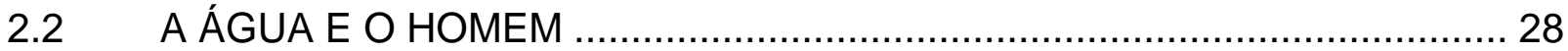

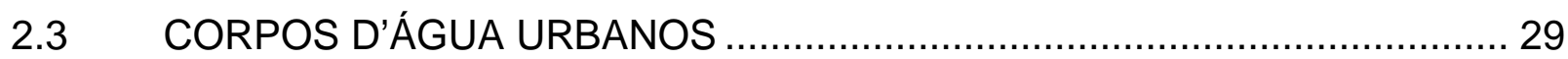

2.4 RECUPERAÇÃO DE CORPOS D’ÁGUA URBANOS ............................... 32

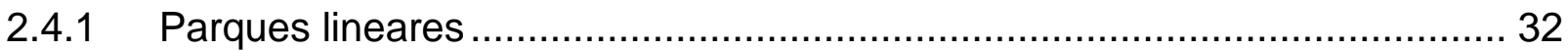

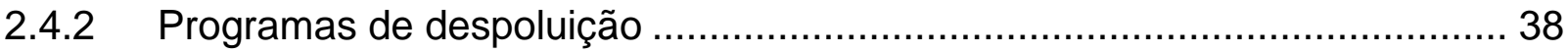

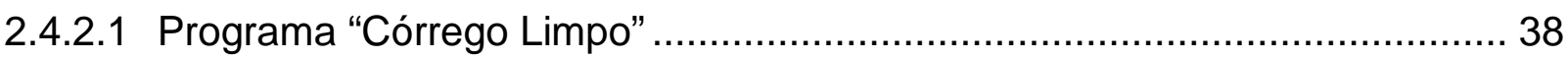

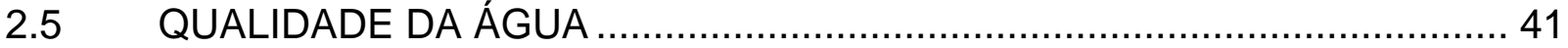

2.5.1 Avaliação da qualidade da água ........................................................ 44

2.5.1.1 Avaliação física e química............................................................ 46

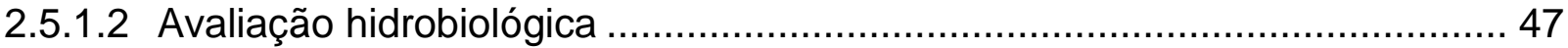

2.6 POLUIÇÃO DA ÁGUA EM ÁREAS URBANAS ..................................... 56

2.6.1 Poluição por carga pontual e difusa ................................................ 56

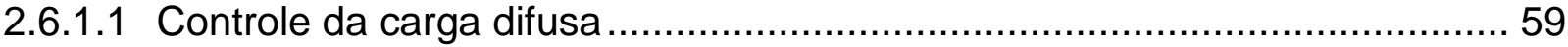

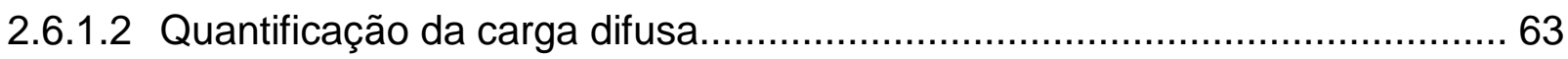

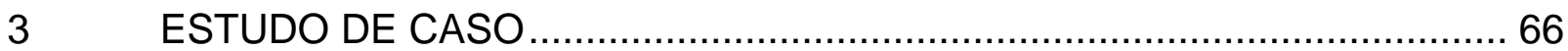

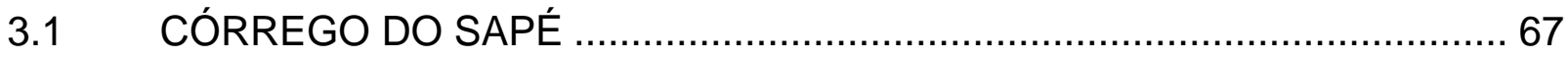

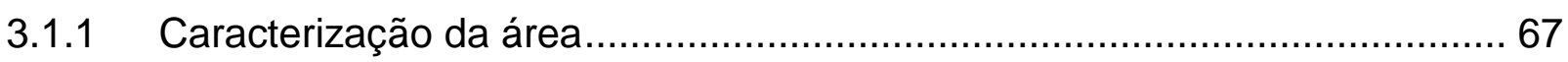

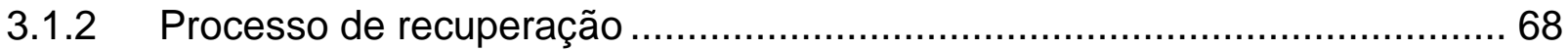

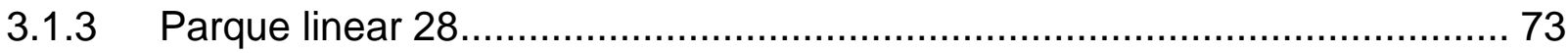

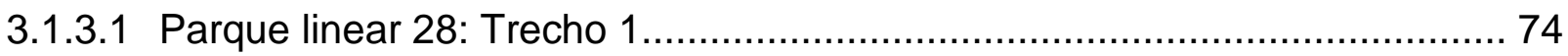

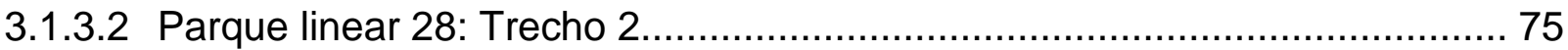

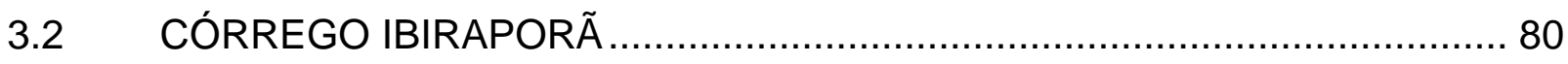

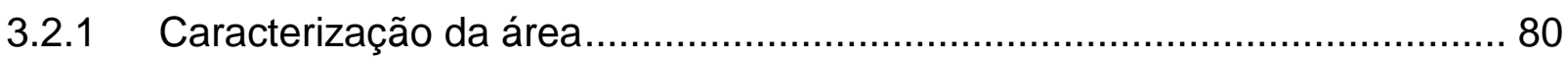

3.2.2 Programa de governança colaborativa ............................................... 80 


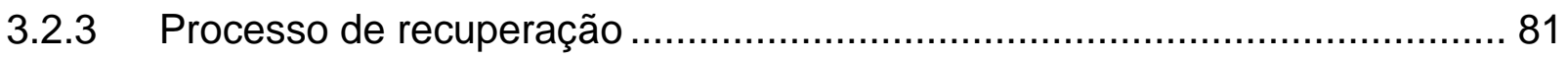

3.3 CANALIZAÇÃO DOS CORPOS D'ÁGUA EM ESTUDO …….....................8 86

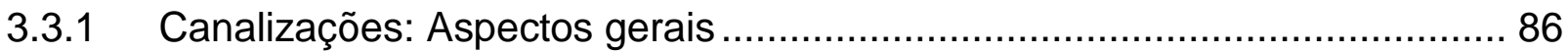

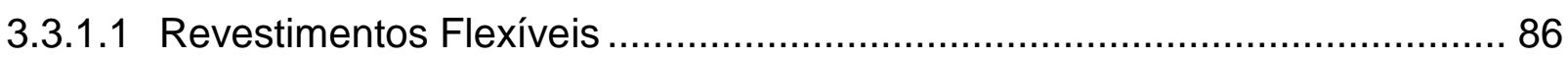

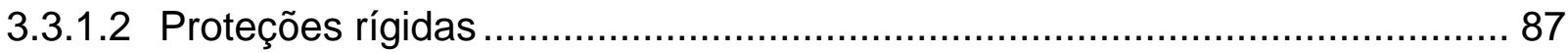

3.3.2 Canalização: Nascente do Sapé (Trecho 1 e 2) e Córrego lbiraporã ............ 88

4 METODOLOGIA, RESULTADOS E DISCUSSÕES ….............................. 90

4.1 Demanda bioquímica de oxigênio (DBO) ……........................................ 90

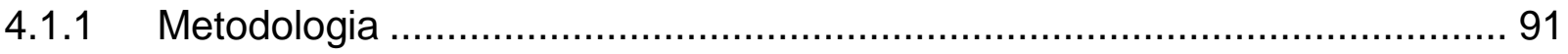

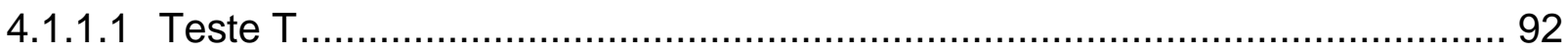

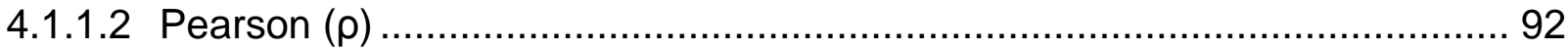

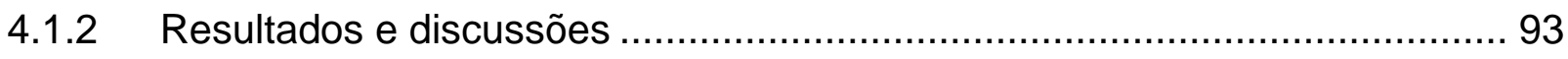

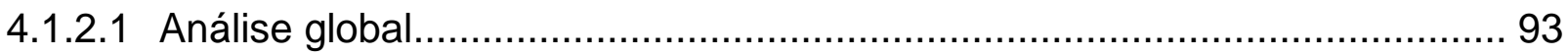

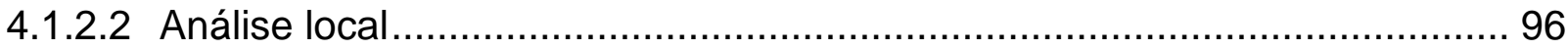

4.1.2.3 Recuperação dos corpos d'água em estudo ............................................ 103

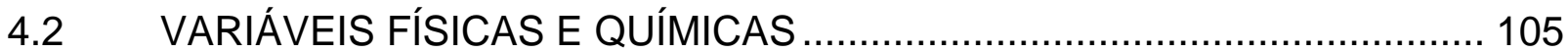

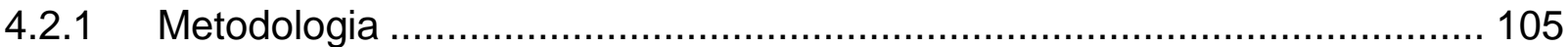

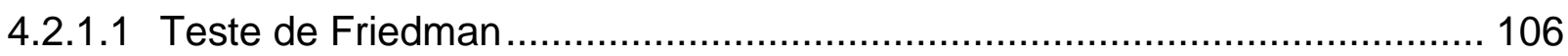

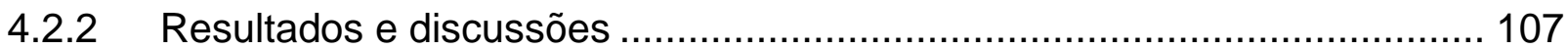

4.2.2.1 Variáveis físicas e químicas: Nascente do Sapé ..................................... 107

4.2.2.2 Variáveis físicas e químicas: Córrego Ibiraporã........................................ 109

4.3 UNIDADE DE CARGA (UC) ......................................................... 113

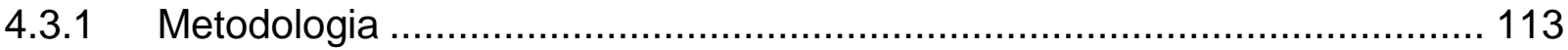

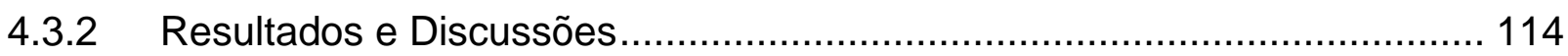

4.3.2.1 Unidade de carga (UC): Córrego Ibiraporã e Nascente do Sapé................. 114

4.3.2.2 Acumulo de carga difusa na superfície da bacia....................................... 116

4.4 COMUNIDADE BENTÔNICA......................................................... 121

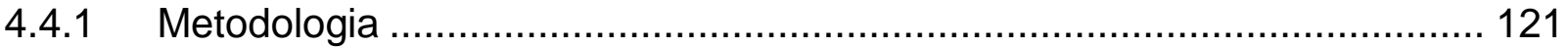

4.4.1.1 Coleta através de amostrador tipo Surber ............................................. 121 
4.4.1.2 Coleta através de instalação de armadilha com substrato. 123

4.4.1.3 Índices biológicos utilizados ............................................................... 128

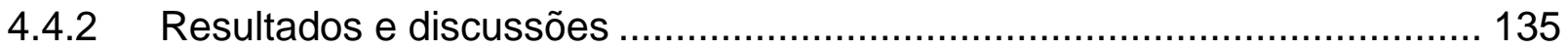

4.4.2.1 Comunidade bentônica: Nascente do Sapé ............................................. 126

4.4.2.2 Comunidade bentônica: Córrego Ibiraporã ............................................ 135

4.4.2.3 Evolução da qualidade de corpos d'água em áreas urbanas .................... 142

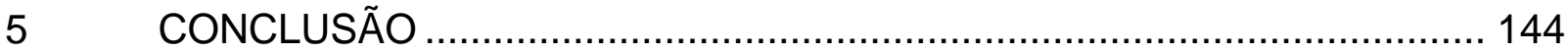

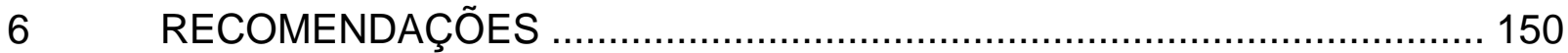

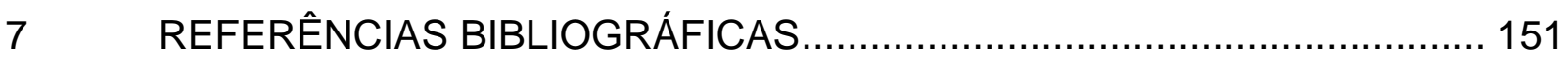

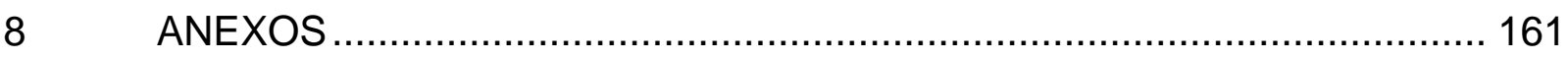




\section{INTRODUÇÃo}

Nos últimos séculos nossa sociedade passou por grandes mudanças, que foram marcadas pelo crescimento populacional acelerado e a inversão no estilo de vida do homem que passou a habitar os centros urbanos, o que levou a mudanças radicais no padrão de interação entre o homem e a paisagem e no padrão da sua demanda por recursos naturais, levando a um aumento do seu potencial de impacto sobre o meio ambiente. Toda essa mudança no estilo de vida da população traz consigo um grande risco à manutenção de um meio ambiente equilibrado, já que o crescente processo de urbanização não vem acompanhado por um sólido planejamento urbano. Como resultado deste processo não coordenado temos o desmatamento, a impermeabilização excessiva do solo, o adensamento, a ocupação de áreas de várzea, a poluição dos corpos d'água e inúmeros outros prejuízos para o meio ambiente. Deste modo, nossa sociedade enfrenta um grande desafio, que é o de melhor gerir sua relação com o ambiente, a fim de conter esta crise ambiental.

Em relação aos recursos hídricos, o processo acelerado de urbanização traz consigo impactos profundos nos corpos d'água em áreas urbanas e, em uma sociedade que demanda cada vez mais água, faz parte deste desafio conter a deteriorização deste recurso e a recuperação daqueles já comprometidos. Para tanto é necessário compreender os processos envolvidos na recuperação destes cursos d'água e desenvolver técnicas de manejo para que estes sejam reintegrados à paisagem. Além disso, a recuperação de corpos d'água em áreas urbanas é de grande importância para manutenção de um ambiente urbano saudável, de modo que à medida que estes corpos são reintegrados à paisagem urbana, eles passam a ser aceitos pela população que passa a enxergar o corpo d'água não só como fonte de problemas, mas sim como sinônimo de qualidade ambiental e de vida. Portanto esse processo de recuperação se torna palpável à medida que cresce a discussão em torno do assunto e também à medida que a população é envolvida no processo.

Atualmente há diversos programas de âmbito municipal, estadual e federal no Brasil que visam à recuperação de corpos d'água em áreas urbanas, mas que na grande maioria das vezes não alcançam sua máxima eficiência, por desprezar a importância da participação da população da bacia hidrográfica no processo, desta 
forma é preciso desenvolver ferramentas, a fim de garantir uma gestão integrada da bacia hidrográfica. Outro desafio enfrentado por estes programas de despoluição é a influência da carga difusa, que faz com que processos de despoluição baseados na remoção de cargas pontuais não sejam totalmente eficientes. É o caso dos córregos utilizados neste estudo, que mesmo tendo passado por um programa de controle de cargas pontuais, como é o caso do programa "Córrego Limpo", ainda assim não se encontram totalmente despoluídos devido à influência da carga difusa. Portanto, faz se necessário a elaboração de planos estratégicos que atuem em todos os aspectos envolvidos na recuperação dos corpos d'água, a fim de garantir resultados mais efetivos.

O programa "Córrego Limpo" implementa em algumas de suas bacias em processo de despoluição um programa piloto de gestão participativa, a fim de promover a consolidação do processo e tem obtido sucesso em seu propósito, uma vez que nestas bacias o programa tem resultado em uma despoluição mais efetiva. Uma destas bacias é a do Córrego Ibiraporã, compreendido neste estudo para avaliação do seu processo de recuperação que como veremos vem evoluindo devido à implementação desta gestão participativa.

Outro instrumento de manejo de águas urbanas é a implantação de parques lineares ao longo de corpos d'água a fim de proteger estes da influência direta da erosão, da carga difusa e de promover a qualidade ambiental e de vida da população que fará uso deste parque para recreação. O córrego do Sapé, compreendido neste estudo teve seu primeiro trecho despoluído na primeira etapa do programa e terá seu trecho final despoluído na terceira etapa do programa ao final de 2012, contando com a implementação do Parque linear 28 em suas margens. Os processos envolvidos na implementação deste parque linear serão avaliados neste estudo para melhor compreensão deste processo.

\subsection{OBJETIVOS}

O objetivo geral é, através do estudo de caso, auxiliar na compreensão dos desafios envolvidos no processo de recuperação de corpos d'água em áreas urbanas. Assim através da revisão bibliográfica será possível ajudar na compreensão de todas as etapas envolvidas no processo, bem como caracterizar os 
fenômenos físicos, químicos e biológicos desses microambientes. São objetivos específicos deste trabalho:

- Analisar a relevância da implantação de parques lineares como medida auxiliar à revitalização de corpos d'água;

- Analisar a eficiência do programa "Córrego Limpo" na despoluição dos córregos contemplados pelo programa;

- Análise da produção de carga difusa pelo método da UC (Unidade de Carga) das bacias dos córregos lbiraporã e Nascente do Sapé, tornando possível avaliar a influência do potencial poluidor de cada uma delas sobre seus respectivos corpos d'água;

- Análise das variáveis físicas e químicas de tempo seco e tempo chuvoso, para avaliação da influência da carga difusa e caracterização da qualidade da água dos corpos d'água em estudo;

- Análise da comunidade bentônica através da aplicação dos índices de avaliação biológica; e

- Analisar a importância da utilização de indicadores físicos, químicos e biológicos na avaliação da qualidade da água. 


\section{REVISÃO BIBLIOGRÁFICA}

\subsection{CRESCIMENTO POPULACIONAL E A OCUPAÇÃO DO SOLO}

Estima-se que, há cerca de 2000 anos, a população global era de aproximadamente 300 milhões de habitantes, e só após 1600 anos a população do mundo dobrou para 600 milhões, portanto, a humanidade levou dezenas de milhares de anos para alcançar o primeiro bilhão de habitantes, o que só aconteceu por volta de 1802. A partir deste ponto foram necessários somente mais 125 anos para dobrar a população, alcançando assim, por volta de 1927, dois bilhões de habitantes. O terceiro bilhão foi atingido 34 anos depois, em 1961 (PNUD, 2010). Em 31 de outubro de 2011 a população mundial atingiu a incrivel marca de 7 bilhões de habitantes. São muitas as consequências negativas desse crescimento acelerado como a questão da escassez de alimentos e o impacto que está população gera sobre o planeta.

O IBGE (2006) classifica o tipo de uso do solo em quatro tipos, áreas antrópicas não agrícolas, área antrópicas agrícolas, áreas de vegetação natural e águas. A distribuição destes usos se dá, ao longo do desenvolvimento da nossa sociedade, em função do estilo de vida do homem em períodos específicos que é influenciado fortemente pela matriz energética utilizada bem como dos tipos de processos produtivos utilizados.

Há pouco tempo, a maior parte da população tinha uma vida restrita ao ambiente rural ao passo que nos dias de hoje essa realidade mudou e uma parcela significativa da população passou a habitar os centros urbanos. Devido à concentração de infraestrutura, estes centros exerceram em maior escala no passado e continuam exercendo um grande poder atrativo para a população rural que migra em busca de oportunidades de trabalho e melhores condições de vida, mas muitas vezes esta mudança não é voluntária, sendo a população indireta e diretamente obrigada a migrar para os centros urbanos devido a mudanças na estrutura produtiva no campo que prioriza o grande produtor e exclui os pequenos do processo. No entanto, esse processo constante e acelerado faz com que as cidades não consigam suprir essa demanda e que esta população imigrante acabe sendo marginalizada e por falta de opção, acabem vivendo em moradias 
inadequadas e sem acesso a serviços básicos como educação, saneamento e saúde.

As áreas urbanas concentram aproximadamente $80 \%$ das moradias precárias, que segundo a Organização das Nações Unidas, são aquelas que têm adensamento excessivo, são feitas de materiais não duráveis e erigidas em áreas de mananciais ou de risco, o que é reflexo da concentração populacional nestas áreas e que por falta de planejamento, não suprem as necessidades dessa população, causando sua degradação social e consequentemente a degradação ambiental (PNUD, 2010).

Segundo o Relatório do Desenvolvimento Humano - PNUD (2010) calcula-se que atualmente aproximadamente metade da população mundial habite cidades e dessa população urbana, estima-se que uma proporção de três para vinte pessoas se encontra nas metrópoles e megalópoles, ou seja, cidades de grande porte, com alta concentração de infraestrutura e altos índices de adensamento humano. Tais características fazem com que estas cidades sejam conhecidas também por concentrarem diversos problemas de ordem social e ambiental.

O relatório do Fundo das Nações Unidas para a população - UNFAP apresenta dados alarmantes sobre o desenvolvimento das megalópoles, ou seja, cidades com mais de 10 milhões de habitantes. Em 1975 o mundo já contava com 5 delas, passando para 19 em 2000 e a previsão e de que atinjamos a incrível marca de 23 megalópoles até o ano de 2015, fenômeno mais marcante no hemisfério sul do planeta. Além disso, o relatório revela que a metade dos seres humanos vive somente com 2 dólares por dia; que a África apresenta o maior crescimento urbano do globo com uma taxa de aproximadamente 4\% ao ano; e que metade da população do planeta vive em áreas urbanas, áreas estas que representam cerca de $80 \%$ das emissões de carbono (DROBENKO, s/d).

No Brasil, a população urbana superou a população rural na década de 70 e hoje já conta com mais de $80 \%$ da sua população vivendo no ambiente urbano (ANA, 2012). Como resultado do quão acelerado e sem planejamento foi este processo de ocupação e expansão do espaço urbano, temos as mazelas da vida urbana nas grandes cidades brasileiras, como a criminalidade, desigualdade social, 
extinção das áreas verdes e a poluição da água, do solo e do ar. O Gráfico da llustração 01 a seguir mostra a evolução histórica da população rural e urbana no Brasil entre 1940 e 2010, demonstrando como o fenômeno da urbanização se deu no país.

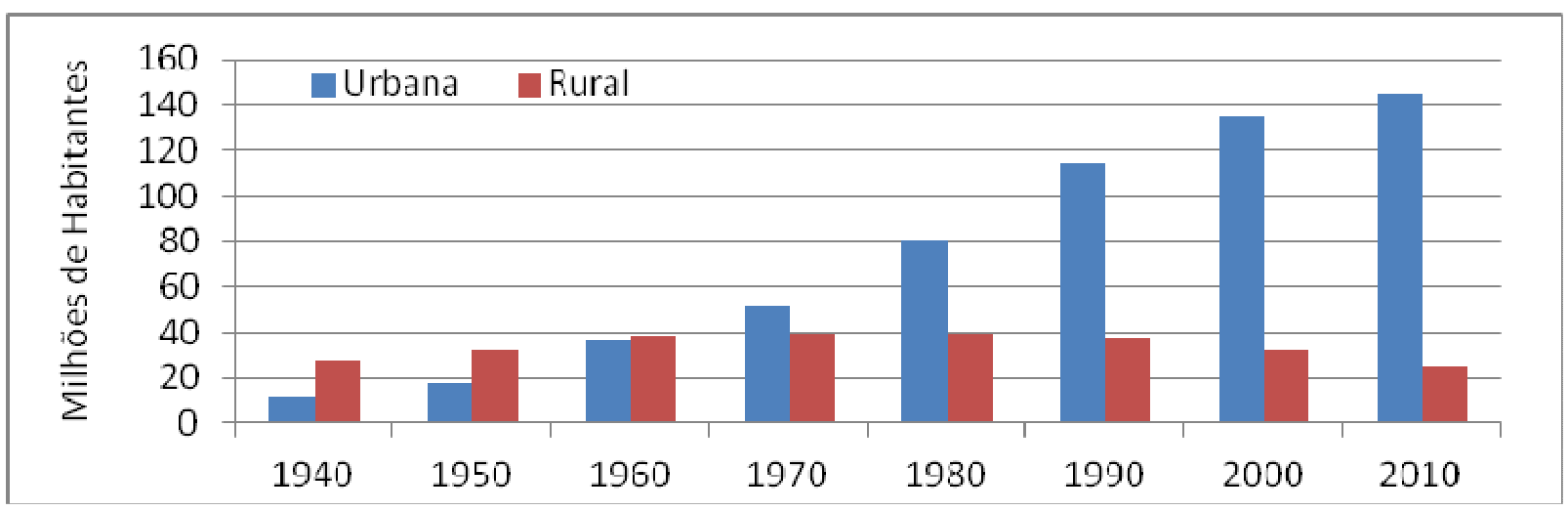

llustração 01 - População Rural e Urbana no Brasil. Fonte: Adaptado de ANA (2012).

Esse crescente processo de mudança nas características populacionais e de ocupação do solo tem trazido impactos principalmente sobre os recursos hídricos, já que, como o corpo d'água é reflexo dos fenômenos que ocorrem em sua bacia, devido à dinâmica do aporte de sedimentos, quando mudamos o tipo de uso do solo na bacia, também mudamos o corpo d'água ali presente, afetando diretamente a fauna e a flora presente neste ou dele dependente.

Os corpos d'água em áreas urbanas têm suas características alteradas principalmente devido às mudanças efetuadas na sua geometria natural e pela compactação e impermeabilização do solo na sua bacia contribuinte. Além disso, a qualidade de suas águas é comprometida devido ao lançamento de cargas pontuais, como esgotos domésticos e industriais, e devido à carga difusa. A diminuição da qualidade destes corpos d'água traz inúmeros e incalculáveis danos ao meio ambiente, uma vez que todo ser vivo depende de diversas formas da água para existir e particularmente à nossa sociedade que depende deste recurso para seu consumo direto e para viabilizar seus processos produtivos. Apesar do papel fundamental do recurso água para o homem, o que presenciamos é a poluição quase que total dos corpos d'água em áreas urbanas, comprometendo o seu aproveitamento até mesmo como elemento paisagístico. 


\subsection{A ÁGUA E O HOMEM}

A relação do homem com o recurso água é complexa, pois extrapola a dependência no nível da sobrevivência biológica, uma vez que a sociedade se moldou com base no uso deste recurso e depende dele também para a geração de energia, sua locomoção, seus processos produtivos e o lazer. Portanto a importância da manutenção da qualidade deste recurso é notória, mas infelizmente o que se vê na prática não traduz a dimensão desta importância e o acesso à água potável não é uma realidade unânime em todo o mundo.

Nos países desenvolvidos, onde o saneamento básico já está consolidado, a maior parte da população tem acesso à água potável, no entanto, esta realidade não é universal e muitos países em desenvolvimento encontram-se ainda longe de atingir tal realidade. O Gráfico da llustração 02 a seguir apresenta o resultado de pesquisas realizadas pela Organização Mundial de Saúde (OMS) em conjunto com o Fundo das Nações Unidas para a Infância (UNICEF) na Etiópia, Jordânia, Nicarágua, Nigéria, e Tajiquistão, entre 2004 e 2005 para avaliação da qualidade da água consumida por estes povos e a previsão de consumo para os próximos anos. (BAIN et al., 2012). Neste gráfico o país em situação mais crítica é a Etiópia que apresenta atualmente uma taxa de acesso à água potável de cerca de $30 \%$ e segundo a projeção realizada atingirá a taxa de atendimento de pouco mais que $50 \%$ em 2015 , ou seja, países com este perfil ainda enfrentarão um longo percurso até que toda a sua população tenha acesso a este recurso.

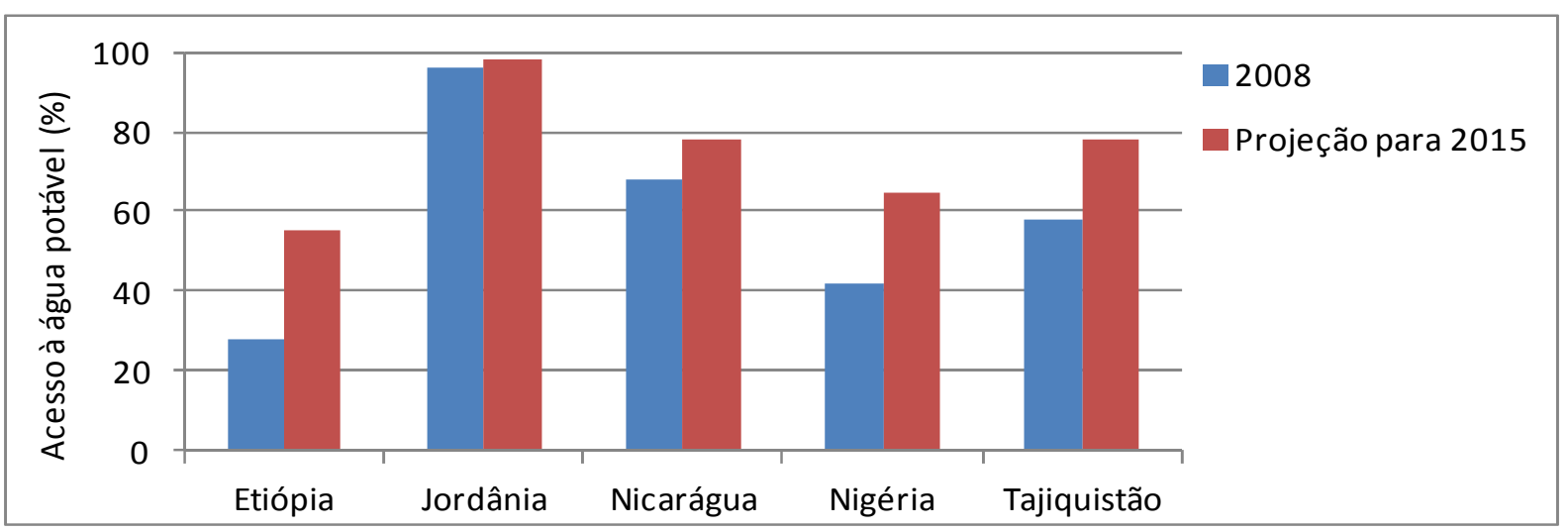

Ilustração 02 - Acesso à água potável na Etiópia, Jordânia, Nicarágua, Nigéria, e Tajiquistão, entre 2004 e 2005 e a previsão do acesso em 2015. Fonte: Adaptado de Bain et al. (2012). 
No Brasil, devido em partes às suas dimensões territoriais e à concentração de renda, temos uma situação irregular com relação ao acesso à água potável em cada região do país, sendo o acesso maior na região sul e sudeste e menor na região norte, como mostrado no Gráfico da llustração 03.

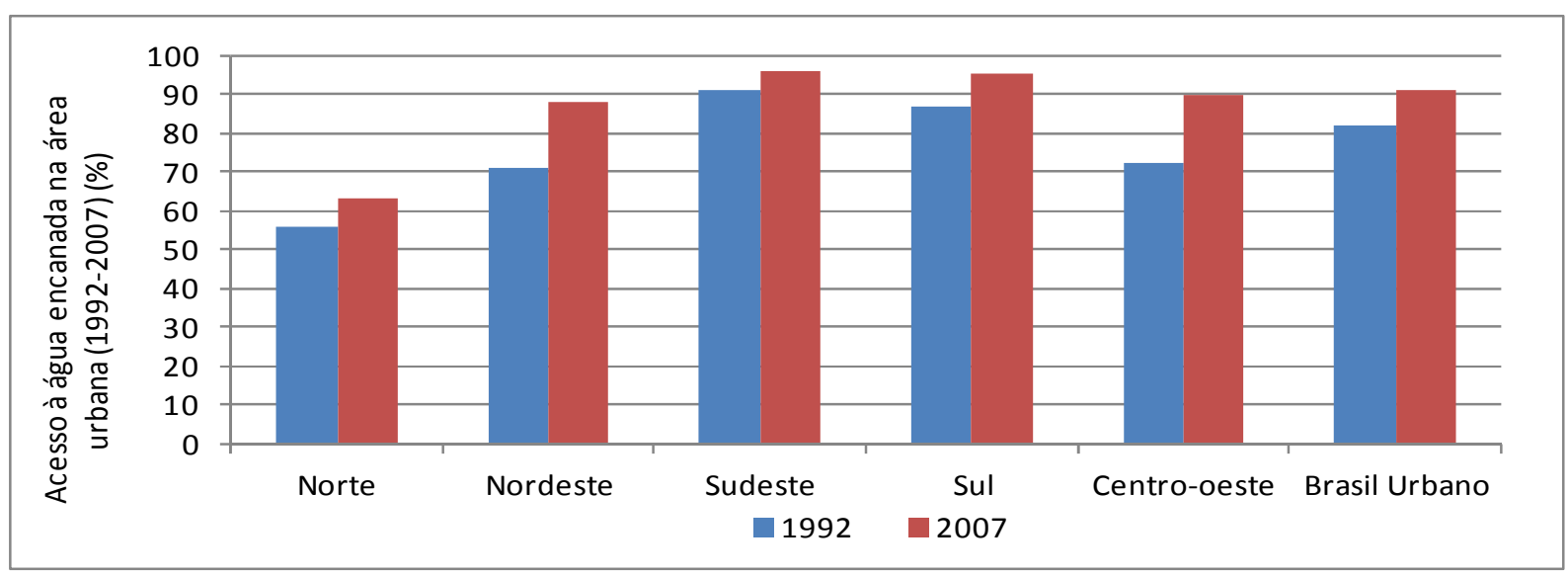

llustração 03 - Acesso à água potável no Brasil (Área urbana) em 1992 e 2007. Fonte: Elaborado pela autora a partir de IBGE (s/d).

A questão do acesso à água se agrava à medida que este recurso não é de fácil acesso para todas as regiões e muitas vezes quando disponível, a qualidade deste recurso é degradada, o que ocorre principalmente em regiões urbanas.

\subsection{CORPOS D'ÁGUA URBANOS}

Os corpos d'água desde o inicio da formação das grandes civilizações foram tidos como sinônimo de fartura, por serem eles os provedores dos recursos que permitiam o desenvolvimento destas, sendo essas sociedades chamadas apropriadamente de hidráulicas devido a essa relação direta com as águas. No entanto, nos dias de hoje os corpos d'água urbanos fazem parte de um contrassenso se considerada a sua importância no passado, pois para a maioria dos moradores das grandes cidades eles representam apenas fontes de problemas, que foram na verdade resultado da ocupação não planejada do espaço urbano.

Segundo Tucci (2008), a gestão das águas no meio urbano passou nos países mais desenvolvidos, por quatro fases, sendo elas:

- Primeira fase: pré-higienista, até o inicio do século XX, na qual o esgoto era lançado sem qualquer preocupação em fossas ou no corpo d'água mais próximo; 
- Segunda fase: Higienista, antes de 1970, na qual o conceito vigente era o de afastar os esgotos para longe da cidade através de coletores e a canalização dos corpos d'água a fim de externalizar o problema das inundações;

- Terceira fase: Corretiva, entre 1970 e 1990, na qual há a implantação de tratamento de esgotos domésticos e industriais e o surgimento de técnicas de amortecimento do escoamento;

- Quarta fase: por fim a fase atual do sistema, chamada de Desenvolvimento Sustentável, na qual há a preocupação em dar tratamento terciário aos esgotos e o surgimento de programas que visam à recuperação dos corpos d'água, através da despoluição e restituição da vegetação, e integração ao ambiente urbano, como a criação de parques lineares.

No Brasil temos uma situação não homogênea, reflexo da distribuição de renda no país e da heterogeneidade climática e hídrica, assim, podemos encontrar no país regiões enquadradas, com base nestes critérios, na primeira fase (Préhigienista), caso das periferias e áreas mais carentes; na segunda fase (Higienista), caso de centros urbanos que só fazem a coleta de seus esgotos como muitas cidades interioranas; na terceira fase (Corretiva), caso das grandes cidades como São Paulo-SP, Campinas-SP, Porto Alegre-RS e outras tantas que estão em fase de consolidação do saneamento; e na quarta fase (Desenvolvimento Sustentável) caso de bairros planejados.

O enquadramento nestas quatro fases de gestão das águas é complexo quando tratamos de megalópoles como São Paulo, uma vez que dentro da própria cidade há uma grande heterogeneidade na sua ocupação, onde podemos encontrar edifícios que fazem uso de sistemas modernos, como o de coleta à vácuo de esgotos, visando à máxima economia de água, e o tratamento avançado de seus efluentes, viabilizando o reaproveitamento desta água servida para usos menos nobres; mas também não é preciso percorrer grandes distâncias destes para encontrar moradias precárias localizadas às margens de corpos d'águas, lançando diretamente neles seus efluentes. Tal disparidade é fruto da desigualdade social típica dos núcleos urbanos. A llustração 04 , a seguir, demonstra a situação, mostrando a Favela do Sapé no bairro do Rio Pequeno localizado na região oeste de São Paulo, onde é possível visualizar as saídas das instalações prediais de 
esgotos sanitários das moradias nas margens do Córrego do Sapé, voltadas para o canal. Por outro lado, próximo a Favela, encontra-se o Centro Empresarial Raposo Tavares que faz uso de tratamento avançado para reuso da sua água servida.

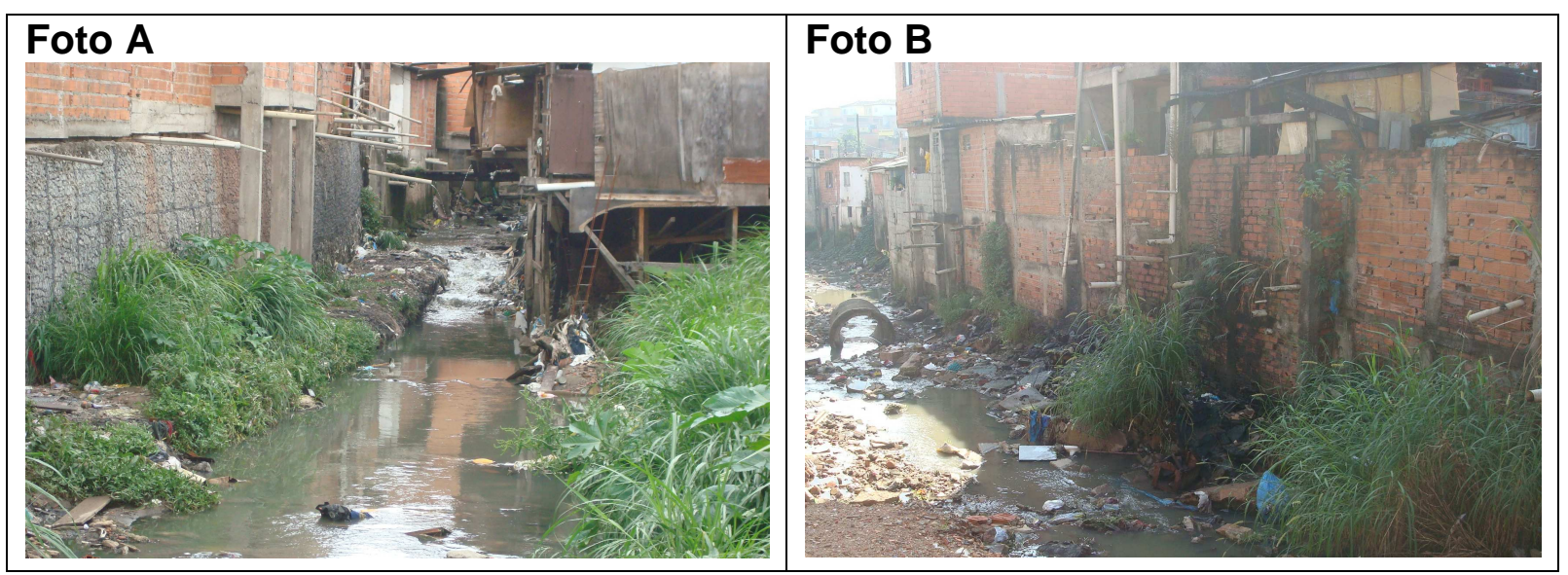

llustração 04 - Favela do Sapé - Saída das instalações prediais de esgotos sanitários das moradias localizadas nas margens do Córrego do Sapé. Fonte: Cortesia de Andréia Sandrini - Coordenadora das ações do programa "Córrego Limpo" na Zona Oeste.

Segundo o monitoramento realizado pela ANA em 2010 em corpos d'água em regiões urbanas no Brasil, $47 \%$ dos corpos d'água monitorados apresentaram índice de qualidade da água péssimo ou ruim, estando a maior parcela destes corpos d'água situados nas capitais do país como São Paulo, Curitiba, Belo Horizonte, Salvador, Goiânia e Vitória ou em cidades de médio e grande porte como Campinas e Juiz de Fora, como mostrado no Gráfico da llustração 05 (ANA, 2012).

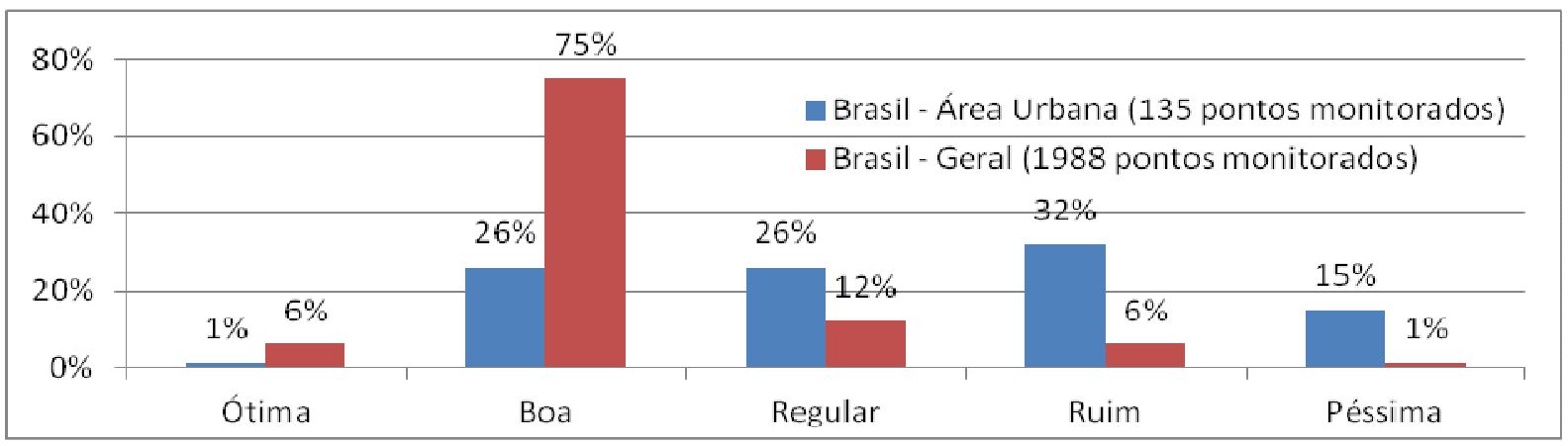

llustração 05 - Situação dos corpos d'água monitorados em 2010 - Fonte: Adaptado de ANA (2012).

O desenvolvimento das cidades se deu excluindo os corpos d'água de qualquer participação na vida urbana, os corpos foram engessados, tamponados e 
no melhor dos casos esse tamponamento deixou como resquício de que um dia tal lugar havia sido um vale, a presença de canteiros centrais com alguma área verde, como é o caso das Avenidas Nove de Julho, Pacaembu, Vinte e três de Maio e Sumaré no município de São Paulo. As gerações atuais que trafegam por estas Avenidas, muitas vezes nem imaginam que outrora tais lugares abrigavam rios e riachos (BARTALINI, 2004).

\subsection{RECUPERAÇÃO DE CORPOS D'ÁGUA URBANOS}

As primeiras ações voltadas para recuperação de corpos d'água urbanos se deram nos países desenvolvidos, que atingiram resultados eficientes na recuperação de seus corpos d'água através da implantação de programas que visam à eliminação da carga pontual e difusa, de parques lineares e programas de gestão participativa nas bacias hidrográficas, resultando na criação de leis que estabelecem as condições para conservação e recuperação de ambientes aquáticos nestes países, como o "Clean Water Act" nos Estados Unidos (1972), a "Directiva quadro da água" na União Europeia (2000) e a "Water Resources Act" na Austrália (2007) (MACEDO et al., 2011).

Como a preocupação com a recuperação dos corpos d'água é resultado quase que imediato da consolidação do saneamento básico, no Brasil, em regiões onde o saneamento encontra-se consolidado ou em processo de consolidação, surge a necessidade de compreender as técnicas de recuperação e as etapas envolvidas neste processo, para tanto diretrizes como as da "Clean Water Act" são utilizadas como referência. No entanto, no país ainda há regiões em que as condições sanitárias são precárias e a preocupação com a qualidade ambiental fica em segundo plano o que agrava ainda mais a consolidação do processo.

\subsubsection{Parques lineares}

O conceito de parques urbanos vem dos movimentos de parques, ocorridos entre o século XVIII e XIX, sendo representado na Inglaterra pelo Movimento dos parques ingleses; na França pelo movimento "Haussmanniano" (Cujo nome se deve ao modelo de reformulação urbana sugerida pelo Barão Haussmann em Paris); e nos Estados Unidos pelo movimento dos Parques Americanos. O que todos estes movimentos têm em comum é a ideia de usar a paisagem como instrumento 
paisagístico, a fim de eliminar as mazelas trazidas pelo adensamento populacional e a utilização deste recurso como instrumento de lazer propiciando o aumento da qualidade de vida da população urbana (FRIEDRICH, 2007)

Assim, como consequência do amadurecimento destes conceitos e do reconhecimento da importância das áreas verdes para o espaço urbano, segundo Friedrich (2007), em 1865 o arquiteto e paisagista norte-americano, Frederick Law Olmsted introduziu o conceito de Parkways, que seriam ligações diretas entre parques e outras área abertas, ficando famoso por ter concebido parques urbanos como o "Central Park" de Nova lorque e o parque "Mont-Royal" de Montreal.

No Brasil os urbanistas Saturnino de Brito, Ulhoa Cintra e Prestes Maia, sugeriram a implantação de áreas verdes ao longo de importantes cursos d'água de São Paulo, como os Rios Tietê, Pinheiros e Córregos Tatuapé, da Mooca e do Ipiranga, no intuito de integra-los no "circuito de Parkways", o que beneficiaria a cidade com uma extensa rede de parques lineares. No entanto, a visão de tais urbanistas era a Higienista, onde tais ares verdes funcionariam como uma barreira ao contato direto da população, as isolando das doenças de veiculação hídrica, de insetos - comuns em áreas alagadiças - e de outros vetores, evitando assim problemas de saúde pública. A ideia de criar parques nas margens dos rios brasileiros, a fim de manter um cinturão verde, foi proposta também pelo arquiteto e urbanista inglês Barry Parker, um dos precursores do conceito de "Cidades-jardins", em 1918. No entanto, tais ideias foram deixadas de lado em função de outras que privilegiavam o uso funcional do espaço urbano. (BARTALINE, 2004)

Além das notórias vantagens sociais, como a valorização paisagística, criação de áreas de lazer e aumento da qualidade de vida, os parques lineares tem importância significativa na redução do impacto das enchentes, já que a área do parque pode ser utilizada como uma ampliação da área do canal. Assim, na ocorrência de chuvas com elevados períodos de retorno (Tr) a inundação seria contida na área do parque, sem causar enchentes nas áreas residenciais. A llustração 06 mostra um esquema do uso de um parque linear típico na prevenção de enchentes. 


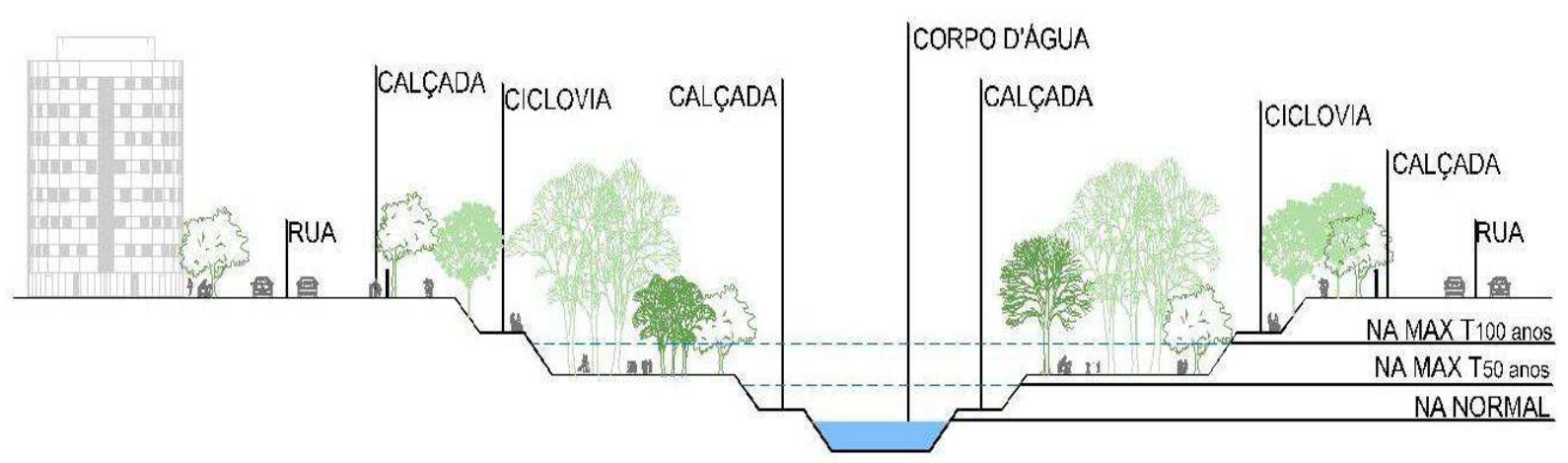

llustração 06 - Esquema mostrando o uso do Parque Linear como instrumento de prevenção a enchentes. Fonte: Elaborado pela autora.

O parque não possui controle sobre o material trazido pelo sistema de drenagem (Galerias), portanto é necessário que o sistema seja interceptado por estruturas que façam a remoção do material transportado.

Atualmente, no município de São Paulo, está em vigor o programa "100 Parques", no qual se insere o programa de parques lineares, que visa expandir as áreas verdes do município, além de promover a recuperação e garantir a proteção das áreas de preservação permanente (APP's). Até 2005 a cidade contava com 34 parques, com o programa houve a criação de mais 43 parques, totalizando 77 parques, dos quais 33 são parques Lineares. (ANMMA, 2011). A Tabela 01 mostra a evolução do programa para as quatro zonas da cidade.

Tabela 01 - Evolução do programa "100 Parques". Fonte: Adaptado de ANMMA (2011).

\begin{tabular}{|c|c|c|c|c|c|}
\cline { 2 - 6 } \multicolumn{1}{c|}{} & \multicolumn{5}{c|}{ Evolução do Programa 100 Parques } \\
\cline { 2 - 6 } \multicolumn{1}{c|}{} & Zona Norte & Zona Centro-Oeste & Zona Leste & Zona Sul & Total \\
\hline Total de Parques até 2005 & 7 & 10 & 7 & 10 & 34 \\
\hline Implantados a partir de 2005 & 6 & 10 & 19 & 8 & 43 \\
\hline $\mathbf{2 0 1 1}$ & 13 & 20 & 26 & 18 & 77 \\
\hline
\end{tabular}

Dentre os parques Lineares implantados e em implantação, um dos mais representativos, é o Parque Linear Várzeas do Tietê, pois seu projeto prevê que com seus $75 \mathrm{~km}$ de extensão e $102 \mathrm{~km}^{2}$ de área, ele seja o maior parque linear do mundo, possuindo ainda $230 \mathrm{~km}$ de ciclovias. O projeto foi dividido em três etapas. A primeira que teve início em 2011 e previsão para conclusão em 2016 contempla a implantação de $25 \mathrm{~km}$ entre o parque ecológico Tietê e o limite do Município de 
Itaquaquecetuba. A segunda que irá de 2016 a 2018, contemplará mais 11,3 km nos municípios de Itaquaquecetuba, Poá e Suzano. Por fim na terceira etapa, com previsão de conclusão para 2020 , serão implantados os $38,7 \mathrm{~km}$ restantes, prolongando o parque até a nascente no município de Salesópolis. (DAEE, s/d).

O parque representa um grande ganho ambiental para o Rio Tietê, que terá sua nascente e áreas de várzea protegidos pelo parque linear, além do ganho social trazido pelas diversas estruturas de lazer a serem implantadas que estão previstas no projeto. Estas áreas de lazer serão implantadas em diversos núcleos ao longo do parque linear que contarão com estruturas de lazer, como quadras, parques, museus e brinquedos recreativos que atenderão a comunidade. A llustração 07 mostra 0 traçado completo do parque linear Várzeas do Tietê desde sua nascente em Salesópolis (Figura A) e o esquema paisagístico da implantação de dois destes núcleos, o Núcleo Jd. Helena (Figura B) e o Núcleo Any Nanci (Figura C).
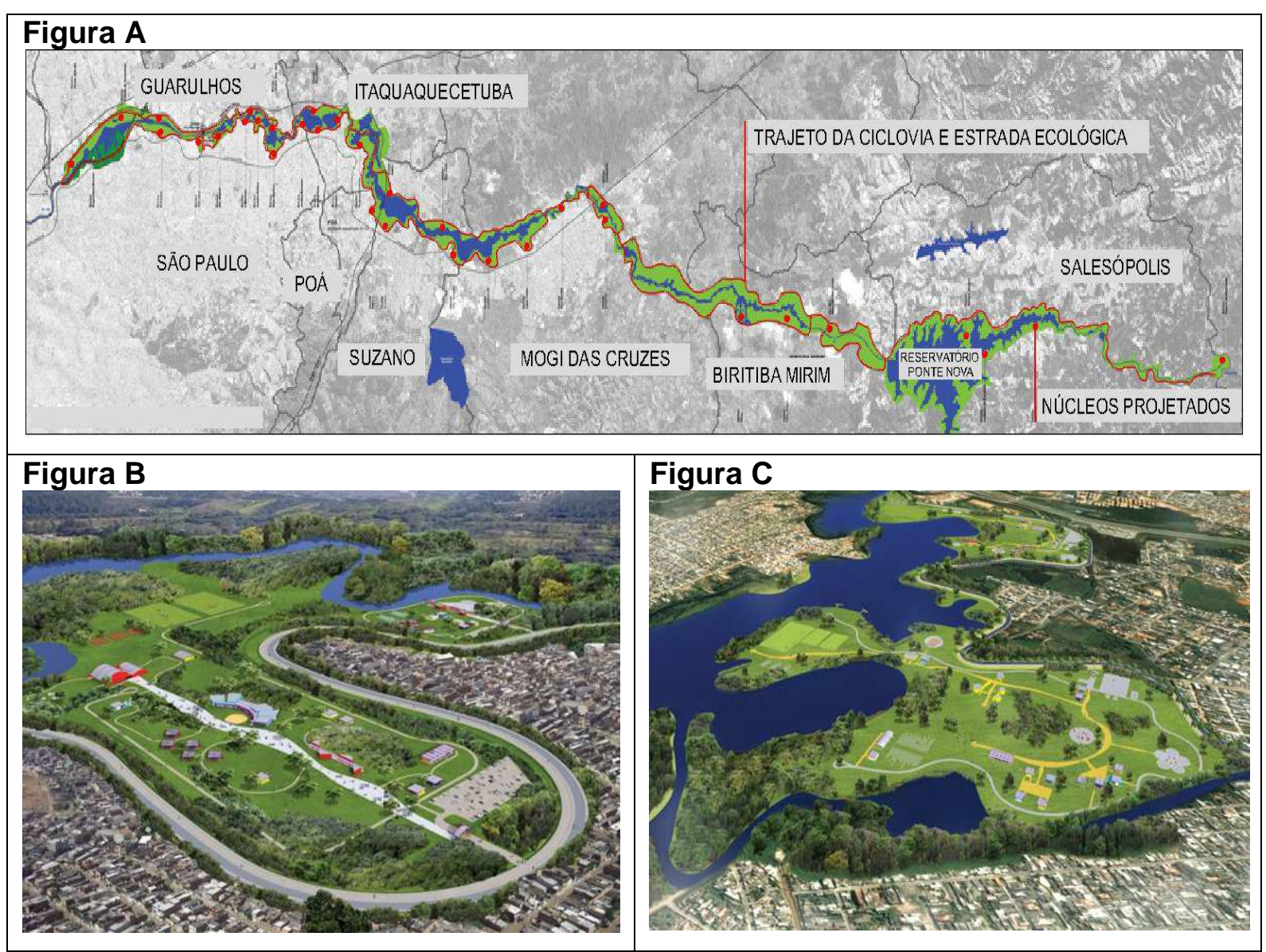

llustração 07 - Figura A: Vista Geral da área do Parque linear Várzeas do Tietê.

Figura B: Núcleo Jd. Helena - São Paulo. Figura C: Núcleo Any Jaci - Guarulhos. Fonte: DAEE (s/d). 
Há também projetos de parques lineares audaciosos que visam não só recuperar, mas também deixar a mostra riachos que há muito tempo estão fluindo em galerias enterradas, como é o caso do Parque Linear Córrego Verde situado na região da Vila Madalena, que para implantação de seu parque linear deixará a céu aberto novamente $1,6 \mathrm{~km}$ de extensão de canal. O projeto prevê ainda a implantação de um "piscinão" para combate a enchentes, a implantação de calçadas permeáveis e equipamentos de lazer (PMSP, s/d), como mostrado na llustração 08 a seguir.

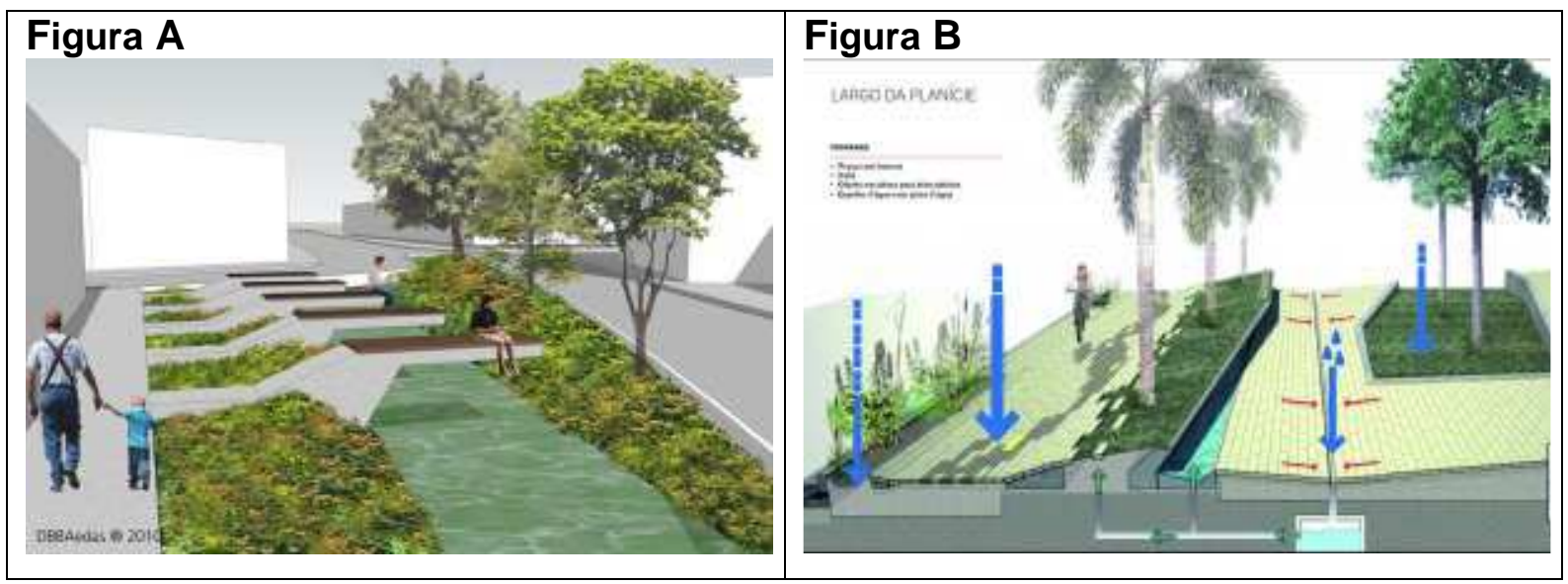

llustração 08 - Figura A: Projeto Urbanístico de um dos trechos do canal. Figura B: Equipamentos públicos e calçadas permeáveis ao longo do canal. Fonte: PMSP $(s / d)$.

Há ainda parques lineares menores que se baseiam na regularização de áreas ocupadas por moradias irregulares, mas nem por isso menos importantes, já que a implantação em menor escala enfrenta menos entraves se comparada à de parques como o Parque Linear Várzeas do Tietê. Um exemplo é o Parque Linear Canivete, localizado na zona norte do município de São Paulo, na Freguesia do Ó que teve, com a criação do parque linear, $1 \mathrm{~km}$ do córrego Canivete recuperado. (ANMMA, 2011). A sequência de fotos, a seguir, apresentadas na llustração 09, mostra a evolução da implantação do parque linear do córrego Canivetes. Na Foto $A$ vemos a área antes das ações de intervenção, onde é possível visualizar as moradias irregulares às margens do córrego Canivetes e o grau de deterioração do corpo d'água. Já na sequência de Fotos de $B$ a $D$ podemos ver a evolução das obras para implantação do parque que contemplaram a remoção das moradias precárias e remanejamento desta população para os conjuntos habitacionais 
implantados posteriormente na área, criação de áreas de lazer (Parquinhos, equipamentos de ginástica e quadras poliesportivas), regularização do canal e implantação de vegetação nas suas margens. É possível observar a consolidação de tais medidas na Foto E, onde temos o parque linear do córrego Canivetes concluído.
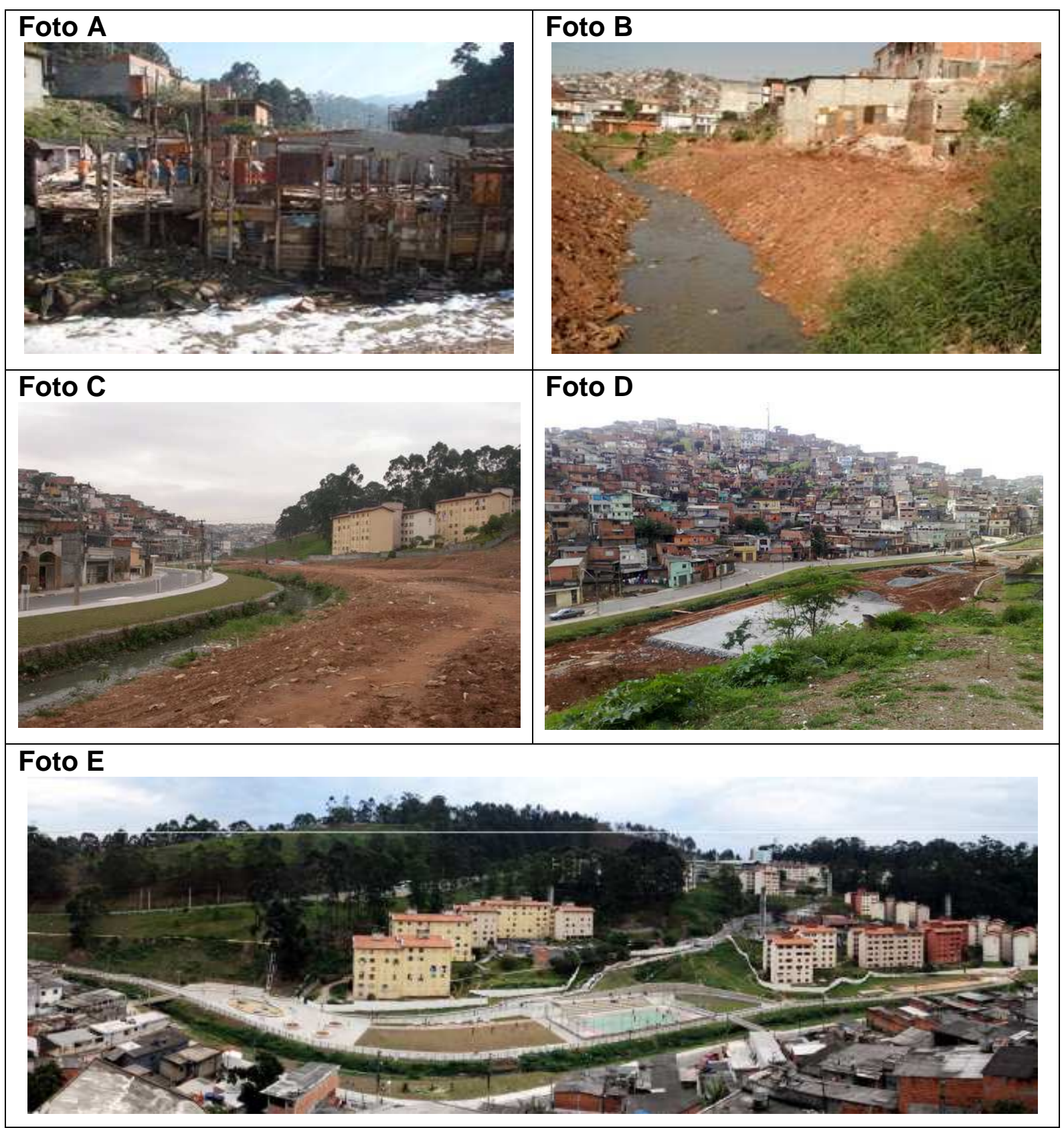

llustração 09 - Parque Linear Canivetes. Foto A: Vista antes das obras de intervenção. Foto $B, C$ e D: Evolução das obras de intervenção para criação do parque linear. Foto E: Parque linear Canivetes concluído - Fonte: Fotos A e B: http://www.znnalinha.com.br/brasilandia/html/linear.html; Fotos 9C e 9D: http://www. panoramio.com/photo/25257058; Foto E: ANMMA (2011). 


\subsubsection{Programas de despoluição}

Em conjunto com os programas de implantação de parques lineares, há também diversos programas em andamento atuando na despoluição de corpos d'água em zonas urbanas através da consolidação do saneamento básico, tais programas visam à eliminação de lançamentos de esgotos nestes corpos através da implantação de redes coletoras, coletores troncos, interceptores, estações elevatórias e estações de tratamento de esgotos. Na região metropolitana de São Paulo, atualmente estão em andamento importantes programas de despoluição, dentre eles destaca-se o "Programa Metropolitano de Mananciais", que inclui Programas de ação localizada, como o:

- Programa Guarapiranga e Billings / Mananciais, que prevê intervenções em áreas de favelas, com a implantação de infraestrutura urbana e obras de saneamento;

- Projeto Orla Guarapiranga, que prevê a execução de parques, ciclovias, calçadas permeáveis e gradis ao longo das margens da represa Guarapiranga, permitindo maior integração da população com a represa;

- Programa Pró-Billings - Programa Integrado de Melhoria Ambiental na Área de Mananciais da Represa Billings no Município de São Bernardo do Campo, que tem enfoque no controle da ocupação em áreas de interesse ambiental, e implantação de obras de saneamento;

- Programa "Córrego Limpo", que se destaca por ter suas ações concentradas em áreas urbanas já consolidadas, no intuito de corrigir as deficiências dos sistemas de esgotamento já implantados, garantindo que as vazões coletadas sejam em sua totalidade transportadas até suas respectivas estações de tratamento de esgotos.

Tais programas têm obtido eficientes resultados na eliminação de cargas pontuais e a atuação em áreas de favela, no intuito de urbanizá-las, tem garantido a oportunidade da criação de Parques Lineares ao longo desses trechos. No item seguinte será dado enfoque no programa "Córrego Limpo", objeto deste estudo.

\subsubsection{Programa "Córrego Limpo"}

A SABESP, em parceria com a prefeitura de São Paulo, iniciou em setembro de 2004 intervenções no sistema de coleta de esgotos da bacia do Córrego Carajás, 
situado na zona norte do município de São Paulo, a fim de aperfeiçoar o sistema, tais intervenções serviriam como projeto piloto para o estudo da viabilidade técnica e financeira da implantação do programa "Córrego Limpo". Na llustração 10, podemos ver a foto do córrego obtida antes do inicio das obras de intervenção, em setembro de 2004 (Foto A) e outra obtida após as intervenções em Dezembro de 2005 (Foto B), onde podemos observar a melhoria visual da qualidade do corpo d'água.
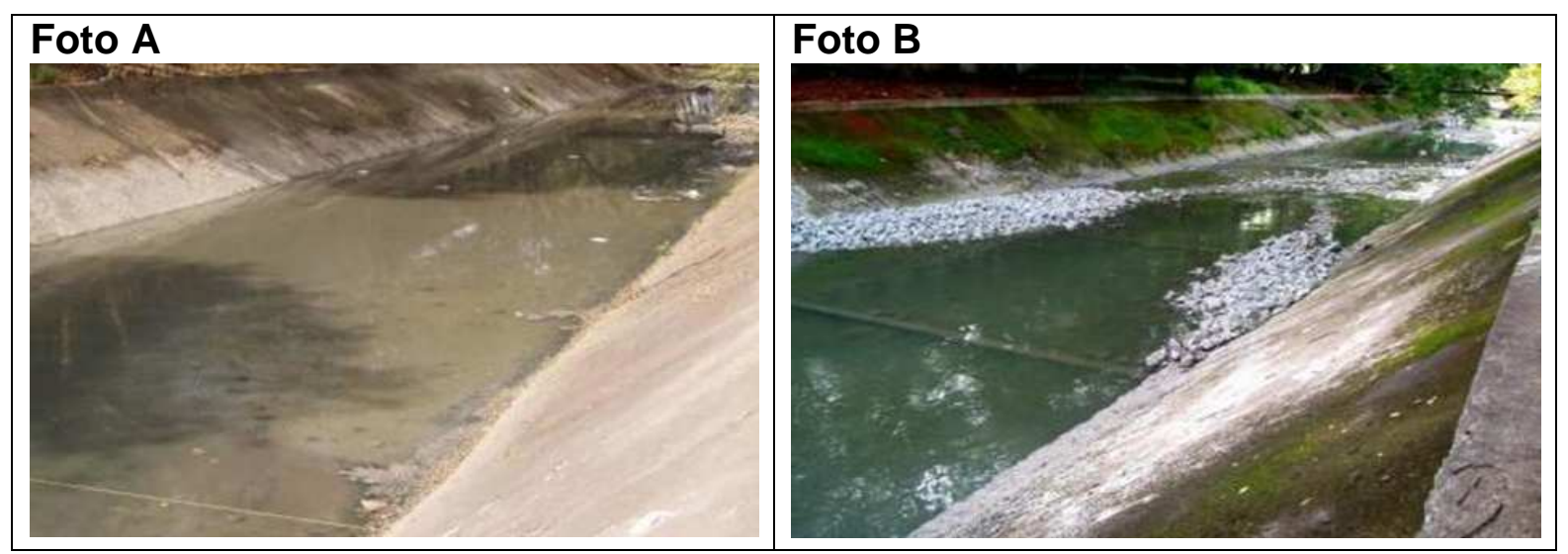

Ilustração 10 - Córrego Carajás - Antes (Foto A) e Depois (Foto B) das obras de intervenção do programa "Córrego Limpo". Fonte: Cortesia de Gilmar Massone SABESP.

No Gráfico da llustração 11, a seguir, pode ser observada a evolução histórica da $\mathrm{DBO}_{5-20}$ no Córrego dos Carajás, que no inicio do monitoramento permanecia acima de $70 \mathrm{mg} / \mathrm{L}$ e após a conclusão das obras de intervenção (Dez/2005) se manteve por volta de $25 \mathrm{mg} / \mathrm{L}$ (O outlier, ou seja, a discrepância apresentada em meados de novembro de 2005 se deve a um vazamento de esgotos ocorrido durante uma das obras de manutenção do sistema de coleta de esgotos).

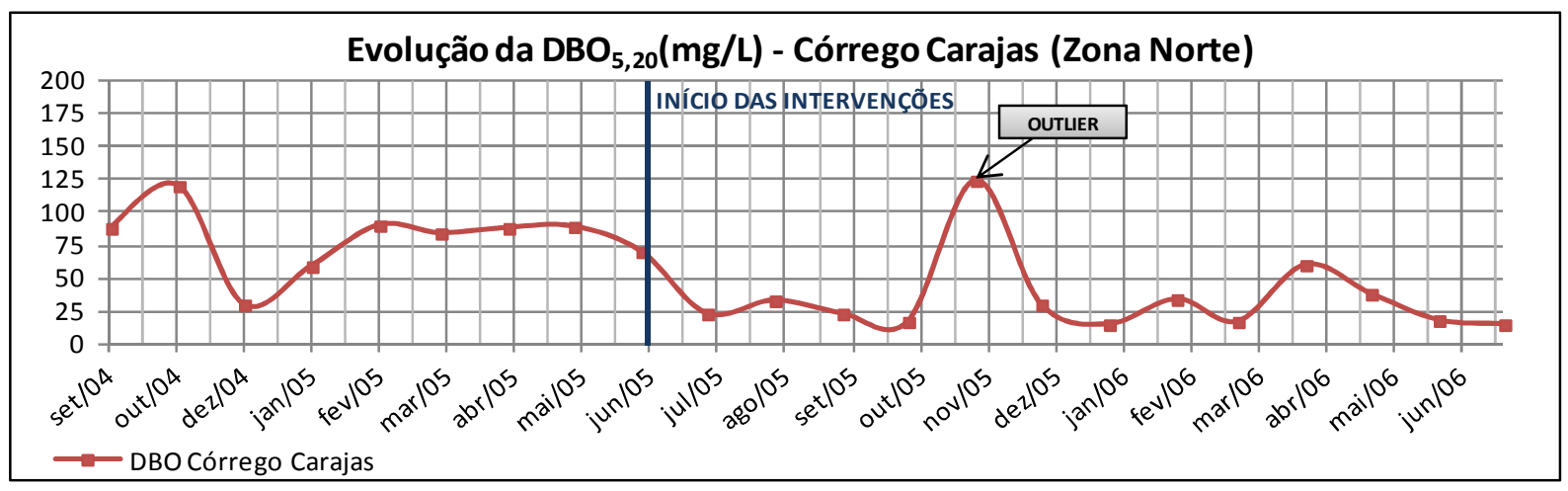

Ilustração 11 - Evolução da DBO5-20 no Córrego Carajás. Fonte: Adaptado de Córrego Limpo (s/d). 
Diante dos bons resultados de recuperação obtidos para o córrego Carajás, o programa "Córrego Limpo" foi iniciado em março de 2007, tendo sua primeira etapa concluída em março de 2009, nesta etapa houve a despoluição por remoção de cargas pontuais de 28 córregos e recuperação de trechos de outros 14 . O programa consiste na recuperação dos córregos através da ampliação das redes coletoras de esgoto e do seu tratamento, eliminação de ligações clandestinas e de lançamentos em galerias pluviais, o indicador de despoluição do programa é a queda no nível da $\mathrm{DBO}_{5-20}$ (CÓRREGO LIMPO, s/d). A Tabela 02 abaixo mostra o resumo das 3 fases do programa até o momento.

Tabela 02 - Resumo das fases do programa "Córrego Limpo". Fonte: Elaborado pela autora a partir de informações cedidas pelo programa "Córrego Limpo".

\begin{tabular}{|c|c|c|c|c|c|}
\hline \multicolumn{7}{|c|}{ Resumo das fases do programa "Córrego Limpo" } \\
\hline Fase & Período & $\begin{array}{c}\text { Número de } \\
\text { Córregos } \\
\text { despoluídos }\end{array}$ & $\begin{array}{c}\text { População } \\
\text { Beneficiada (valor } \\
\text { aproximado) }\end{array}$ & $\begin{array}{c}\text { Esgotos retirados } \\
\text { dos córregos (valor } \\
\text { aproximado) }\end{array}$ & $\begin{array}{c}\text { Investimento } \\
\text { (valor } \\
\text { aproximado) }\end{array}$ \\
\hline $\begin{array}{c}\text { Primeira } \\
\text { Etapa }\end{array}$ & $\begin{array}{c}\text { março/2007 a } \\
\text { março/2009 }\end{array}$ & 42 & 800.000 hab & 500 Litros & 140 milhões \\
\hline $\begin{array}{c}\text { Segunda } \\
\text { Etapa }\end{array}$ & $\begin{array}{c}\text { março/2009 a } \\
\text { Abril/2010 }\end{array}$ & 58 & 840.000 hab & 550Litros & 300 milhões \\
\hline $\begin{array}{c}\text { Terceira } \\
\text { Etapa }\end{array}$ & $\begin{array}{c}\text { Abril/2010 a } \\
\text { Dezembro/2012 }\end{array}$ & 50 & 700.000 hab & 700Litros & 750 milhões \\
\hline \multicolumn{7}{|c|}{ Total } & 150 & 2340000 hab & 1750Litros & 1,190 bilhões \\
\hline
\end{tabular}

Dentre os programas de despoluição, o programa "Córrego Limpo" se destaca, por agir na otimização dos sistemas de esgotamento sanitário que devido às ligações clandestinas no sistema de drenagem urbana, acaba perdendo parte da vazão que deveria ser conduzida pelo sistema ao tratamento, vazão está que acaba sendo lançada no corpo d'água receptor do sistema de drenagem.

Além dessas ações e dentro do conceito de Best Management Practices (Detalhado no item a seguir), o programa "Córrego Limpo" realiza a capacitação de técnicos que atuam em algumas bacias do programa, a fim de tornar efetivas as ações de recuperação do programa. Tal capacitação é feita através da implantação de estratégias de governança colaborativa inicialmente nas bacias de cinco córregos do programa, Córrego Cruzeiro do Sul, Córrego Charles Gaulle, Córrego Cipoaba, 
Córrego Itupu e o Córrego Ibiraporã que é objeto deste estudo. (CÓRREGO LIMPO, $\mathrm{s} / \mathrm{d})$.

A estratégia de governança colaborativa faz uso do "Modelo dos Níveis de Ação Colaborativa" (MNAC). O modelo proposto pelo professor Mark Imperial, da Universidade da Carolina do Norte, foi testado em bacias norte-americanas, que apesar de maiores, apresentavam os mesmos desafios, abordando a questão da colaboração em três níveis: operacional (Que trata de intervenções como implantação de infraestrutura, processos educativos, monitoramento e avaliação, portanto envolve, na maior parte, serviços governamentais.), de formulação de políticas (Que tem caráter orientador, incrementando a comunicação entre os atores, coordenando ações e integrando políticas para alavancar os objetivos coletivos) e institucional (Atividades que influenciam, restringem, incrementam e promovem as ações no nível operacional e formulação de política) (CÓRREGO LIMPO, s/d).

\subsection{QUALIDADE DA ÁGUA}

A disponibilidade da água na forma líquida é um dos fatores mais importantes a moldar os ecossistemas, esse recurso natural é essencial para a manutenção da vida e deve conter substâncias que a propiciem. A qualidade da água depende da capacidade desta de diluir e transportar substâncias benéficas e maléficas à vida (BRAGA, 2002).

A alteração da qualidade da água agrava o problema da escassez desse recurso, já que apesar de ser abundante, esta distribuída de forma irregular no planeta, além disso, outro problema a ser considerado como resultado da alteração da qualidade da água é o das doenças de veiculação hídrica. A Organização Mundial de Saúde (OMS) estima que 25 milhões de pessoas por ano no mundo morrem devido a doenças como cólera e diarreias, isso ocorre principalmente em países onde o acesso à água tratada e potável não é ainda uma realidade palpável (BRAGA, 2002).

A resolução CONAMA 357 de 17 de março de 2005, discorre sobre as diretrizes para o enquadramento de corpos d'água, bem como os padrões e condições de lançamento para preservação destes corpos e manutenção da sua classe de uso. As classes de qualidade segundo a resolução são o conjunto de 
condições e padrões necessários para atendimento dos usos preponderantes atuais ou futuros, ou seja, são determinados na qualidade da água a ser mantida pelos corpos d'água enquadrados para atendimento dos usos estipulados.

A resolução caracteriza três tipos de águas, segundo sua salinidade: 1) Águas doces: aquelas que apresentam salinidade igual ou inferior a 0,5\%०; 2) Águas salobras: aquelas que apresentam salinidade superior a 0,5\%o e inferior a 30\%o; e 3) Águas salinas: aquelas que apresentam salinidade superior a 30\%o. Além disso, classifica as águas segundo sua qualidade e seu uso, sendo as águas doces divididas nas seguintes classes: Classe especial, Classe I, Classe II, Classe III e Classe IV. A classificação de corpos d'água no Brasil encontra diversos entraves devido à generalidade da resolução CONAMA, necessitando ainda de revisões e de melhor detalhamento aplicado às características dos corpos d'água do país. A Tabela 03, a seguir, apresenta o resumo das características de cada classe.

Tabela 03 - Resumo das características das classes de qualidade das águas. Fonte: Elaborado pela autora a partir de CONAMA (2005).

\begin{tabular}{|c|c|c|}
\hline & $\stackrel{\mathscr{P}}{\supset}$ & $\begin{array}{l}\text { Abastecimento público (após tratamento simplificado); proteção das comunidades } \\
\text { aquáticas; recreação de contato primário; irrigação de hortalicias e frutas que tenham } \\
\text { contato direto com esta água; e proteção de comunidades aquaticas em terras indigenas. }\end{array}$ \\
\hline & 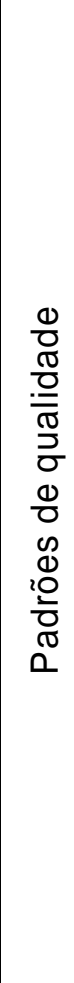 & $\begin{array}{l}\text { a) não verificação de efeito tóxico crônico a organismos, de acordo com os critérios } \\
\text { estabelecidos pelo órgão ambiental competente, ou, na sua ausência, por instituições } \\
\text { nacionais ou internacionais renomadas, comprovado pela realização de ensaio } \\
\text { ecotoxicológico padronizado ou outro método cientificamente reconhecido. } \\
\text { b) materiais flutuantes, inclusive espumas não naturais: virtualmente ausentes; } \\
\text { c) óleos e graxas: virtualmente ausentes; } \\
\text { d) substâncias que comuniquem gosto ou odor: virtualmente ausentes; } \\
\text { e) corantes provenientes de fontes antrópicas: virtualmente ausentes; } \\
\text { f) resíduos sólidos objetáveis: virtualmente ausentes; } \\
\text { g) coliformes termotolerantes: para o uso de recreação de contato primário deverão ser } \\
\text { obedecidos os padrões de qualidade de balneabilidade, previstos na Resolução } \\
\text { CONAMA no } 274, \text { de } 2000 \text {. Para os demais usos, não deverá ser excedido um limite de } \\
200 \text { coliformes termotolerantes por } 100 \text { mililitros em } 80 \% \text { ou mais, de pelo menos } 6 \\
\text { amostras, coletadas durante o período de um ano, com freqüência bimestral. A E. Coli } \\
\text { poderá ser determinada em substituição ao parâmetro coliformes termotolerantes de } \\
\text { acordo com limites estabelecidos pelo órgão ambiental competente; } \\
\text { h) DBO } 5 \text { dias a } 20^{\circ} \mathrm{C} \text { até } 3 \text { mg/L O2; } \\
\text { i) OD, em qualquer amostra, não inferior a } 6 \text { mg/L O2; } \\
\text { j) turbidez até } 40 \text { unidades nefelométrica de turbidez (UNT); } \\
\text { I) cor verdadeira: nível de cor natural do corpo de água em mg PtL; e } \\
\text { m) pH: } 6,0 \text { a } 9,0 \text {. }\end{array}$ \\
\hline
\end{tabular}


Tabela 03 - Resumo das características das classes de qualidade das águas. Fonte: Elaborado pela autora a partir de CONAMA (2005). (Continuação).

\begin{tabular}{|c|c|c|}
\hline \multirow[b]{2}{*}{$\begin{array}{l}= \\
= \\
= \\
\mathscr{D} \\
\frac{\mathbb{0}}{0} \\
0\end{array}$} & & $\begin{array}{l}\text { Abastecimento público (após tratamento convencional); proteção das comunidades } \\
\text { aquáticas; recreação de contato primário; irrigação de hortalicias e frutas que não tenham } \\
\text { contato direto com esta água; irrigação de áreas verdes públicas como praças cujo } \\
\text { público possa ter contato direto com esta água; aquicultura e atividade de pesca. }\end{array}$ \\
\hline & & $\begin{array}{l}\text { As mesmas condições e padrões da classe } 1 \text { à exceção do seguinte: } \\
\text { I - não será permitida a presença de corantes provenientes de fontes antrópicas que não } \\
\text { sejam removíveis por processo de coagulação, sedimentação e filtração convencionais; } \\
\text { II - coliformes termotolerantes: para uso de recreação de contato primário deverá ser } \\
\text { obedecida a Resolução CONAMA no } 274 \text {, de } 2000 \text {. Para os demais usos, não deverá ser } \\
\text { excedido um limite de } 1.000 \text { coliformes termotolerantes por } 100 \text { mililitros em } 80 \% \text { ou mais } \\
\text { de pelo menos } 6 \text { (seis) amostras coletadas durante o período de um ano, com freqüência } \\
\text { bimestral. A E. coli poderá ser determinada em substituição ao parâmetro coliformes } \\
\text { termotolerantes de acordo com limites estabelecidos pelo órgão ambiental competente; } \\
\text { III - cor verdadeira: até } 75 \mathrm{mg} \text { Pt/L; } \\
\text { IV - turbidez: até } 100 \text { UNT; } \\
\text { V - DBO } 5 \text { dias a } 20^{\circ} \mathrm{C} \text { até } 5 \mathrm{mg} / \mathrm{L} \text { O2; } \\
\text { VI - OD, em qualquer amostra, não inferior a } 5 \mathrm{mg} / \mathrm{L} \text { O2; } \\
\text { VII - clorofila a: até } 30 \mu \mathrm{Mg} / \mathrm{L} ; \\
\text { VIII - densidade de cianobactérias: até } 50000 \mathrm{cel} / \mathrm{mL} \text { ou } 5 \text { mm3/L; e, } \\
\text { IX - fósforo total: } \\
\text { a) até } 0,030 \mathrm{mg} / \mathrm{L} \text {, em ambientes lênticos; e, } \\
\text { b) até } 0,050 \mathrm{mg} / \mathrm{L} \text {, em ambientes intermediários, com tempo de residência entre } 2 \text { e } 40 \\
\text { dias, e tributários diretos de ambiente lêntico. }\end{array}$ \\
\hline & $\stackrel{\mathscr{D}}{\supset}$ & $\begin{array}{l}\text { Abastecimento público (após tratamento convencional ou avançado); recreação de } \\
\text { contato secundário; irrigação de culturas arbóreas, cerealíferas e forrageiras; pesca } \\
\text { amadora; e à dessedentação de animais. }\end{array}$ \\
\hline & & $\begin{array}{l}\text { a) não verificação de efeito tóxico agudo a organismos, de acordo com os critérios } \\
\text { estabelecidos pelo órgão ambiental competente, ou, na sua ausência, por instituições } \\
\text { nacionais ou internacionais renomadas, comprovado pela realização de ensaio } \\
\text { ecotoxicológico padronizado ou outro método cientificamente reconhecido; } \\
\text { b) materiais flutuantes, inclusive espumas não naturais: virtualmente ausentes; } \\
\text { c) óleos e graxas: virtualmente ausentes; } \\
\text { d) substâncias que comuniquem gosto ou odor: virtualmente ausentes; } \\
\text { e) não será permitida a presença de corantes provenientes de fontes antrópicas que não } \\
\text { sejam removíveis por processo de coagulação, sedimentação e filtração convencionais; } \\
\text { f) resíduos sólidos objetáveis: virtualmente ausentes; } \\
\text { g) coliformes termotolerantes: para o uso de recreação de contato secundário não deverá } \\
\text { ser excedido um limite de } 2500 \text { coliformes termotolerantes por } 100 \text { mililitros em } 80 \% \text { ou } \\
\text { mais de pelo menos } 6 \text { amostras, coletadas durante o período de um ano, com freqüência } \\
\text { bimestral. Para dessedentação de animais criados confinados não deverá ser excedido o } \\
\text { limite de } 1000 \text { coliformes termotolerantes por } 100 \text { mililitros em } 80 \% \text { ou mais de pelo } \\
\text { menos } 6 \text { amostras, coletadas durante o período de um ano, com freqüência bimestral. } \\
\text { Para os demais usos, não deverá ser excedido um limite de } 4000 \text { coliformes } \\
\text { termotolerantes por } 100 \text { mililitros em } 80 \% \text { ou mais de pelo menos } 6 \text { amostras coletadas } \\
\text { durante o período de um ano, com periodicidade bimestral. A E. Coli poderá ser } \\
\text { determinada em substituição ao parâmetro coliformes termotolerantes de acordo com } \\
\text { limites estabelecidos pelo órgão ambiental competente; } \\
\text { h) cianobactérias para dessedentação de animais: os valores de densidade de } \\
\text { cianobactérias não deverão exceder } 50.000 \text { cel/ml, ou } 5 \text { mm3/L; } \\
\text { i) DBO } 5 \text { dias a } 20^{\circ} \mathrm{C} \text { até } 10 \text { mg/L O2; } \\
\text { j) OD, em qualquer amostra, não inferior a } 4 \text { mg/L O2; } \\
\text { l) turbidez até } 100 \text { UNT; } \\
\text { m) cor verdadeira: até } 75 \text { mg Pt/L; e, } \\
\text { n) pH: } 6,0 \text { a } 9,0 .\end{array}$ \\
\hline
\end{tabular}


Tabela 03 - Resumo das características das classes de qualidade das águas. Fonte: Elaborado pela autora a partir de CONAMA (2005). (Continuação).

\begin{tabular}{|c|c|c|}
\hline & ڤ̊) & Navegação e harmonia paisagistica \\
\hline & $\begin{array}{l}\frac{0}{0} \\
\frac{\pi}{0} \\
\frac{0}{\pi} \\
\frac{0}{0} \\
0 \\
0 \\
0 \\
0 \\
0 \\
\frac{0}{0} \\
\frac{0}{0} \\
1\end{array}$ & $\begin{array}{l}\text { I - materiais flutuantes, inclusive espumas não naturais: virtualmente ausentes; } \\
\text { II - odor e aspecto: não objetáveis; } \\
\text { III - óleos e graxas: toleram-se iridescências; } \\
\text { IV - substâncias facilmente sedimentáveis que contribuam para o assoreamento de canais } \\
\text { de navegação: virtualmente ausentes; } \\
\text { V - fenóis totais (substâncias que reagem com } 4 \text { - aminoantipirina) até } 1,0 \mathrm{mg} / \mathrm{L} \text { de } \\
\text { C6H5OH; } \\
\mathrm{VI} \text { - OD, superior a } 2,0 \mathrm{mg} / \mathrm{L} \text { O2 em qualquer amostra; e, } \\
\mathrm{VII} \text { - pH: } 6,0 \text { a } 9,0 \text {. }\end{array}$ \\
\hline \multirow{2}{*}{ 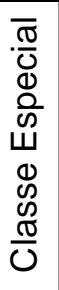 } & $\stackrel{\circ}{\supset}$ & $\begin{array}{l}\text { Abastecimento público (após desinfecção); preservação do equilibrio natural das } \\
\text { comunidades aquáticas; e unidades de concervação de proteção integral. }\end{array}$ \\
\hline & 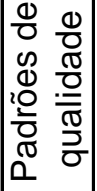 & Caracteristicas naturais \\
\hline
\end{tabular}

\subsubsection{Avaliação da qualidade da água}

A avaliação da qualidade da água pode ser realizada através do monitoramento de diversos componentes que compõe o ecossistema, podendo ser classificados em variáveis físicas, químicas, microbiológicas, hidrobiológicas, ecotoxicológicas (CETESB, s/d). A Tabela 04, a seguir, apresenta a descrição dos principais componentes de cada variável.

Tabela 04 - Variáveis de qualidade das águas. Fonte: Elaborado pela autora a partir de CETESB (s/d).

\begin{tabular}{|l|l|}
\hline Variáveis de qualidade das águas \\
\hline Variáveis físicas: & Variáveis hidrobiológicas: \\
\hline Cor & Clorofila a \\
\hline Série de sólidos & Comunidade fitoplanctônica \\
\hline Temperatura & Comunidade zooplanctônica \\
\hline Transparência & Comunidade bentônica \\
\hline Turbidez & \\
\hline Variáveis microbiológicas: & Variáveis toxicológicas e ecotoxicológicas: \\
\hline Coliformes termotolerantes & Ensaios ecotoxicológicos \\
\hline Enterococos & \\
\hline
\end{tabular}


Tabela 04 - Variáveis de qualidade das águas. Fonte: Elaborado pela autora a partir de CETESB (s/d). (Continuação).

\begin{tabular}{|c|c|c|c|}
\hline \multicolumn{4}{|c|}{ Variáveis de qualidade das águas } \\
\hline \multicolumn{4}{|c|}{ Variáveis químicas: } \\
\hline Alumínio & Cromo & Níquel & Potencial Redox (EH) \\
\hline Bário & Fenóis & Óleos e graxas & Sódio \\
\hline Cádmio & Ferro & Ortofosfato solúvel & Sulfato \\
\hline Chumbo & Fluoreto & Oxigênio Dissolvido (OD) & Surfactantes \\
\hline Cloreto & Fósforo total & Praguicidas organoclorados & \multirow[t]{3}{*}{ Zinco } \\
\hline Cobre & Manganês & Potencial Hidrogeniônico $(\mathrm{pH})$ & \\
\hline Condutividade & Mercúrio & Potássio & \\
\hline \multicolumn{4}{|c|}{ Potencial de formação de triahalometanos } \\
\hline \multicolumn{4}{|c|}{ Carbono orgânico dissolvido e Carbono Orgânico Total (COT) } \\
\hline \multicolumn{4}{|c|}{ Dicloro Difenil Tricloroetano (DDT) } \\
\hline \multicolumn{4}{|c|}{ Demanda Bioquímica de Oxigênio (DBO) } \\
\hline \multicolumn{4}{|c|}{ Demanda Química de Oxigênio (DQO) } \\
\hline \multicolumn{4}{|c|}{ Hidrocarbonetos Aromáticos Policíclios (HAP) } \\
\hline Série de nitrogê & ônia, nitrato, & t̂̂nin & \\
\hline
\end{tabular}

Podemos assim dividir a avaliação das águas de um corpo d’água em dois blocos, que apesar da divisão teórica estão intimamente relacionados, o componente físico e químico e o componente biológico, resultando em duas avaliações possíveis, a avaliação física e química e a avaliação biológica da qualidade das águas.

Segundo Mendes \& Oliveira (2004) durante muito tempo a avaliação física e química de um corpo d'água era a maneira mais rotineira de detecção de poluição, mas hoje com o avanço das técnicas para emprego de indicadores biológicos, houve uma mudança no padrão de monitoramento da qualidade da água, havendo uma integração maior entra as ciências exatas e biológicas no processo. A avaliação biológica de um corpo d'água é indispensável, uma vez que a biota consegue detectar e apresentar respostas mesmo sob influência de pequenas concentrações de poluentes, além disso, as avaliações físicas e químicas são um retrato da qualidade da água no ponto de amostragem e no instante da amostragem, enquanto a avaliação biológica faz um filme da situação do corpo d'água, já que a comunidade aquática é capaz de refletir no presente as alterações geradas em momentos anteriores, bem como acumular resposta de diversas alterações (CORTES et al., 2002). 


\subsubsection{Avaliação física e química}

Costumeiramente monitoramentos de qualidade da água, através de variáveis físicas e químicas, são feitos com base nas seguintes variáveis: $\mathrm{pH}$, turbidez, temperatura, DBO (demanda bioquímica de oxigênio), DQO (demanda química de oxigênio), oxigênio dissolvido, SDT (sólidos dissolvidos totais), presença de metais, óleos e graxas e COV (compostos orgânicos voláteis). As principais características, origem nas águas e os inconvenientes mais comuns destas variáveis estão apresentados na Tabela 05, a seguir.

Tabela 05 - Características das principais variáveis para a determinação da qualidade da água - Fonte: Adaptado de Nascimento (2011).

\begin{tabular}{|c|c|c|}
\hline \multirow{3}{*}{ 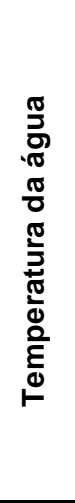 } & $\begin{array}{l}\text { Características } \\
\text { Gerais }\end{array}$ & $\begin{array}{c}\text { Influencia processos biológicos, reações químicas e bioquímicas, caracterizando outros } \\
\text { parâmetros como a densidade, viscosidade e pressão de vapor do meio líquido. É } \\
\text { inversamente proporcional à solubilidade de gases dissolvidos e diretamente } \\
\text { proporcional à solubilidade de sais minerais. }\end{array}$ \\
\hline & $\begin{array}{l}\text { Origem nas } \\
\text { Águas e Fatores } \\
\text { de Alteração }\end{array}$ & $\begin{array}{c}\text { Varia naturalmente nas águas de acordo com a temperatura do ar, apresentando no Brasi } \\
\text { valores entre } 12 \text { e } 30^{\circ} \mathrm{C} \text {. Aumentos significativos de temperatura nos corpos d'água são } \\
\text { geralmente decorrentes de despejos de origem industrial e descargas de usinas } \\
\text { termoelétricas. }\end{array}$ \\
\hline & Inconvenientes & $\begin{array}{c}\text { Variações súbitas de temperatura nas águas causam efeitos danosos aos ecossistemas } \\
\text { aquáticos que se adaptam apenas a pequenas variações. Aumentos de temperatura } \\
\text { resultam na redução do oxigênio dissolvido e no consumo de oxigênio devido à } \\
\text { estimulação das atividades biológicas. }\end{array}$ \\
\hline \multirow{3}{*}{ I } & $\begin{array}{l}\text { Características } \\
\text { Gerais }\end{array}$ & $\begin{array}{c}\text { É a relação numérica que expressa o equilíbrio entre íons }(\mathrm{H}+) \text { e }(\mathrm{OH}-) \text {. Apresenta } \\
\text { variação entre } 0 \text { e 14, sendo } 7,0 \text { o valor neutro. Águas com } \mathrm{pH}<7,0 \text { são consideradas } \\
\text { ácidas, e com } \mathrm{pH}>7,0 \text { básicas. }\end{array}$ \\
\hline & $\begin{array}{l}\text { Origem nas } \\
\text { Águas e Fatores } \\
\text { de Alteração }\end{array}$ & $\begin{array}{l}\text { Alterações naturais advêm da presença de ácidos carbônicos e húmicos dissolvidos. As } \\
\text { maiores alterações no pH são provocadas por despejos industriais e águas residuárias } \\
\text { de minas. }\end{array}$ \\
\hline & Inconvenientes & $\begin{array}{c}\text { Águas com pH baixo ou elevado são agressivas, podendo causar corrosão em } \\
\text { tubulações. Alterações bruscas de } \mathrm{pH} \text { podem causar o desaparecimento de espécies } \\
\text { aquáticas. }\end{array}$ \\
\hline \multirow{3}{*}{ 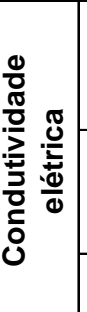 } & $\begin{array}{l}\text { Características } \\
\text { Gerais }\end{array}$ & $\begin{array}{c}\text { É a capacidade da água transmitir corrente elétrica. Apresenta relação proporcional à } \\
\text { concentração de substâncias iônicas dissolvidas. Em águas doces varia de } 30 \text { a } 2000 \\
\mu \mathrm{s} / \mathrm{cm} \text { a } 25^{\circ} \mathrm{C} \text {. }\end{array}$ \\
\hline & $\begin{array}{l}\text { Origem nas } \\
\text { Águas e Fatores } \\
\text { de Alteração }\end{array}$ & $\begin{array}{l}\text { É determinada pela presença de substâncias dissolvidas que se dissociam em ânions e } \\
\text { cátions. Grandes variações decorrem de lançamentos de despejos industriais e de } \\
\text { mineração e esgotos domésticos. }\end{array}$ \\
\hline & Inconvenientes & - \\
\hline \multirow{3}{*}{ 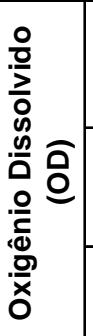 } & $\begin{array}{l}\text { Características } \\
\text { Gerais }\end{array}$ & $\begin{array}{c}\text { Fundamental para a manutenção das comunidades aquáticas aeróbicas. Provêm } \\
\text { naturalmente de processos cinéticos e fotossintéticos. Varia em função da temperatura } \\
\text { da água e pressão atmosférica. }\end{array}$ \\
\hline & $\begin{array}{l}\text { Origem nas } \\
\text { Águas e Fatores } \\
\text { de Alteração }\end{array}$ & $\begin{array}{c}\text { Reduções significativas nos teores de oxigênio dissolvido são provocadas por despejos } \\
\text { principalmente de origem orgânica. }\end{array}$ \\
\hline & Inconvenientes & $\begin{array}{l}\text { Apesar de essencial à vida aeróbica, o oxigênio é fator significante na corrosão de } \\
\text { tubulações de ferro e aço. }\end{array}$ \\
\hline
\end{tabular}


Tabela 05 - Características das principais variáveis para a determinação da qualidade da água - Fonte: Adaptado de Nascimento (2011). (Continuação).

\begin{tabular}{|c|c|c|}
\hline \multirow{3}{*}{$\frac{\mathfrak{d}}{\stackrel{N}{0}}$} & $\begin{array}{c}\text { Características } \\
\text { Gerais }\end{array}$ & $\begin{array}{l}\text { Mede a resistência da água à passagem da luz. É uma característica das águas } \\
\text { correntes, podendo aumentar nos períodos chuvosos. Em águas paradas, como em } \\
\text { lagos e reservatórios, apresenta geralmente valores baixos. }\end{array}$ \\
\hline & $\begin{array}{l}\text { Origem nas } \\
\text { Águas e Fatores } \\
\text { de Alteração }\end{array}$ & $\begin{array}{l}\text { Decorre naturalmente da presença de material em suspensão, plâncton, } \\
\text { microorganismos, argilas e siltes nas águas. Sua principal fonte é o aporte de partículas } \\
\text { de solos provenientes da superfície da bacia hidrográfica, em função de } \\
\text { desmatamentos, processos erosivos e atividades de mineração. Pode também advir do } \\
\text { lançamento de efluentes que contenham material fino. }\end{array}$ \\
\hline & Inconvenientes & $\begin{array}{l}\text { Afeta esteticamente os corpos d'água. Pode causar distúrbios aos ecossistemas } \\
\text { aquáticos devido à redução da penetração da luz. Aumenta os custos de processos de } \\
\text { tratamento para fins de abastecimento público e industrial. }\end{array}$ \\
\hline \multirow{3}{*}{ 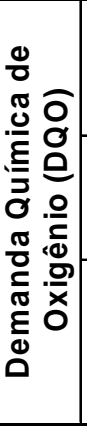 } & $\begin{array}{c}\text { Características } \\
\text { Gerais }\end{array}$ & $\begin{array}{l}\text { É a quantidade de oxigênio necessária para a oxidação da matéria orgânica através de } \\
\text { um agente químico. Parâmetro utilizado no monitoramento de sistemas de tratamento de } \\
\text { efluentes e na caracterização de efluentes industriais. }\end{array}$ \\
\hline & $\begin{array}{l}\text { Origem nas } \\
\text { Águas e Fatores } \\
\text { de Alteração }\end{array}$ & Aumentos de DQO decorrem principalmente de despejos de origem industrial. \\
\hline & Inconvenientes & $\begin{array}{c}\text { Altos índices podem gerar a diminuição e até a extinção do oxigênio presente nas águas; } \\
\text { nessas condições, os processos aeróbicos de degradação orgânica podem ser } \\
\text { substituídos por outros anaeróbicos, gerando alterações substanciais no ecossistema, } \\
\text { inclusive com a extinção das formas de vida oxigênio-dependentes. }\end{array}$ \\
\hline \multirow{3}{*}{ 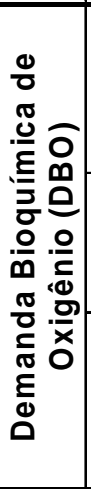 } & $\begin{array}{c}\text { Características } \\
\text { Gerais }\end{array}$ & $\begin{array}{l}\text { Corresponde à quantidade de oxigênio necessária para ocorrer a oxidação da matéria } \\
\text { orgânica biodegradável sob condições aeróbicas. Essa unidade de medida avalia a } \\
\text { quantidade de oxigênio dissolvido (OD) em miligramas (mg), equivalente à quantidade } \\
\text { que será consumida pelos organismos aeróbicos ao degradarem a matéria orgânica. }\end{array}$ \\
\hline & $\begin{array}{l}\text { Origem nas } \\
\text { Águas e Fatores } \\
\text { de Alteração }\end{array}$ & $\begin{array}{l}\text { Ocorre naturalmente nas águas em nível reduzido em função de da degradação de } \\
\text { matéria orgânica (folhas, animais mortos, fezes de animais). Aumentos de DBO são } \\
\text { provocados por despejos de origem predominantemente orgânica. }\end{array}$ \\
\hline & Inconvenientes & $\begin{array}{l}\text { Altos índices podem gerar a diminuição e até a extinção do oxigênio presente nas águas; } \\
\text { nessas condições, os processos aeróbicos de degradação orgânica podem ser } \\
\text { substituídos por outros anaeróbicos, gerando alterações substanciais no ecossistema, } \\
\text { inclusive com a extinção das formas de vida oxigênio-dependentes. }\end{array}$ \\
\hline \multirow{3}{*}{ 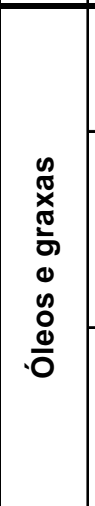 } & $\begin{array}{c}\text { Características } \\
\text { Gerais }\end{array}$ & $\begin{array}{l}\text { São substâncias orgânicas de origem mineral, vegetal ou animal, tais como ácidos } \\
\text { graxos, ceras, óleos, gorduras, sabões e graxas. São geralmente insolúveis em água, } \\
\text { podendo aparecer emulsionados por detergentes, álcalis ou outras substâncias }\end{array}$ \\
\hline & $\begin{array}{l}\text { Origem nas } \\
\text { Águas e Fatores } \\
\text { de Alteração }\end{array}$ & $\begin{array}{c}\text { Sua origem relaciona-se a atividades antropogênicas, uma vez que raramente são } \\
\text { encontrados em águas naturais.Normalmente advêm de despejos e resíduos industriais, } \\
\text { esgotos domésticos, efluentes de } \\
\text { oficinas mecânicas, postos de gasolina, resíduos de embarcações e dragas, estradas, } \\
\text { vias públicas urbanas e aeroportos. }\end{array}$ \\
\hline & Inconvenientes & $\begin{array}{l}\text { Modificam a tensão superficial das águas dificultando as trocas gasosas, sobretudo do } \\
\text { oxigênio, causando, portanto, alterações no ecossistema aquático e nas características } \\
\text { físicas, químicas e biológicas das águas. Em seu processo de decomposição provocam } \\
\text { a redução do OD e a elevação da DBO e DQO. Podem produzir dermatoses no homem. }\end{array}$ \\
\hline
\end{tabular}

\subsubsection{Avaliação hidrobiológica}

Os ecossistemas aquáticos continentais podem ser divididos em lênticos (Possui águas com baixo fluxo, como lagoas, lagos e reservatórios), lóticos (Corpos d'água de água corrente como rios e riachos) e zonas úmidas (Locais cuja principal 
característica é quase que ou permanente saturação do solo, ou seja, áreas inundadas todo ou a maior parte do ano, como brejos e várzeas). Possuem ecossistemas diversos e do ponto de vista da limnologia três comunidades assumem papel central, sendo elas: comunidade de macrófitas aquáticas, comunidade planctônica e comunidade bentônica (ESTEVES, 1998). Estas comunidades são descritas a seguir.

a) Comunidade de macrófitas aquáticas:

A definição mais aceita é de que as comunidades de macrófitas aquáticas são compostas por plantas herbáceas que crescem na água, em solos cobertos por água ou em solos saturados de água, ou seja, habitam desde brejos a ambientes verdadeiramente aquáticos. Macrófitas podem ser definidas como vegetais que retornaram ao ambiente aquático durante seu processo evolutivo, assim apesar de possuírem adaptações ao ambiente aquático, possuem estruturas típicas de plantas terrestres, como cutícula, embora fina, e estômatos que na maioria das espécies é não funcional. São capazes de habitar diferentes ambientes, como: fitotelmos (tanques biológicos vivos, como bromélias que acumulam água em suas bainhas), fontes termais, cachoeiras, lagos, lagoas, represas, brejos, rios, riachos, corredeiras, águas salobras e águas salgadas, demonstrando a grande capacidade de adaptação destes organismos (ESTEVES, 1998).

As macrófitas podem ser agrupadas segundo ao seu biótopo, ou seja, segundo à região ocupada no ecossistema aquático, formando os seguintes grupos: Macrófitas aquáticas emersas (Enraizadas no sedimentos e folhas fora da água), macrófitas aquáticas com folhas flutuantes (Enraizadas no sedimentos e folhas flutuando na superfície), macrófitas submersas enraizadas (Enraizadas no sedimento e totalmente submersas), macrófitas aquáticas submersas livres (Rizoides pouco desenvolvidos, assim ficam flutuando na água, mas totalmente submersas) e macrófitas aquáticas flutuantes (Flutuam na superfície da água) (ESTEVES, 1998).

b) Comunidade planctônica:

O plâncton é constituído pelo fitoplâncton (Algas e cianobactérias), zooplâncton (Pequenos animais) e bacterioplâncton, estes organismos são 
caracterizados por habitarem a coluna d'água e terem pouco ou nenhum poder de locomoção, dependendo muitas vezes da correnteza para se deslocar. A diversidade de fitoplâncton é maior em águas continentais, já a de zooplâncton é maior em ambientes marinhos (ESTEVES, 1998). A llustração 12 e a llustração 13, a seguir, mostram os principais organismos do fitoplâncton e zooplâncton encontrados em ambientes aquáticos continentais.

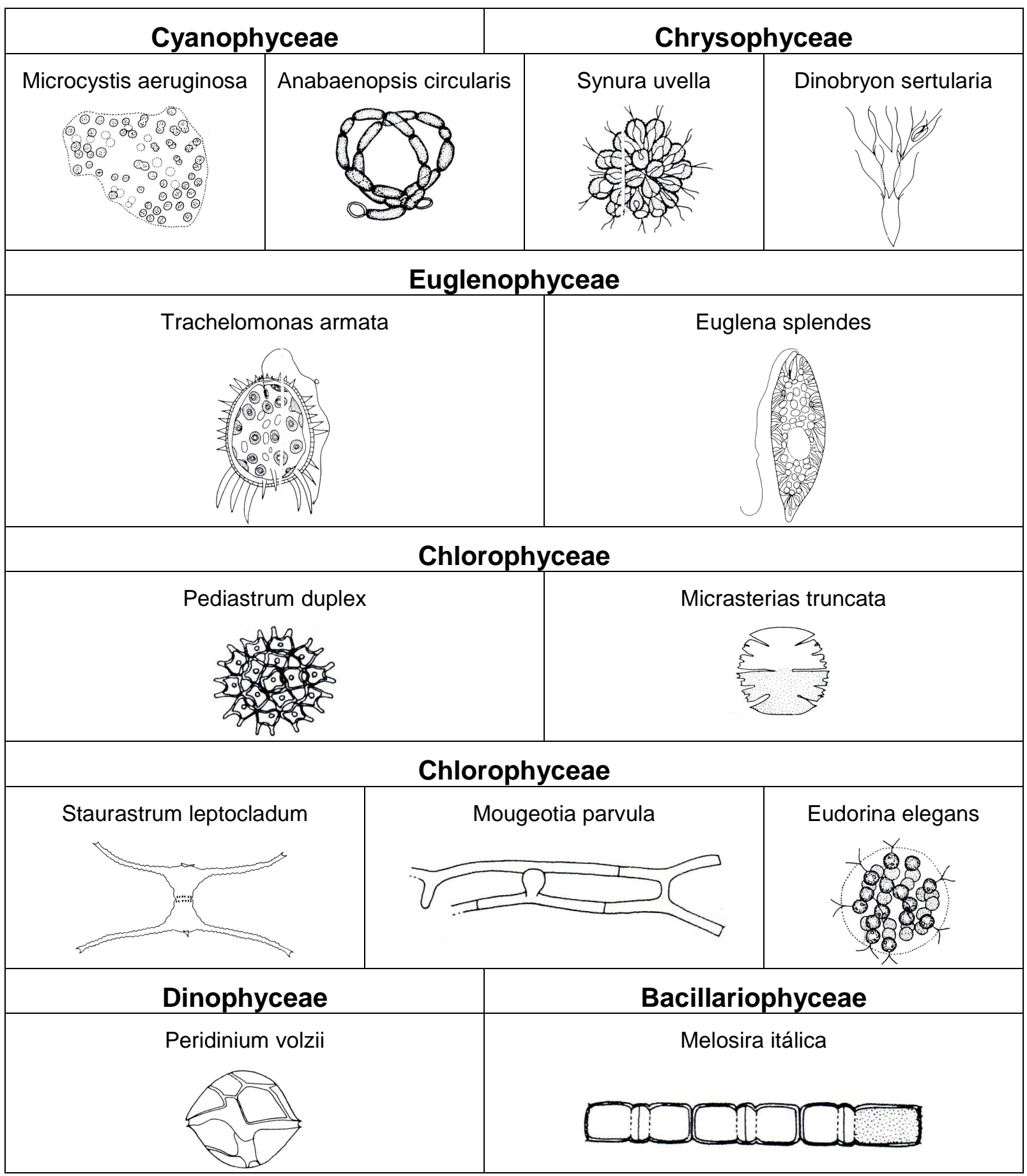

Ilustração 12 - Principais grupos taxonômicos do fitoplâncton encontrados em ambientes aquáticos continentais. Fonte: Adaptado de Esteves (1998). 


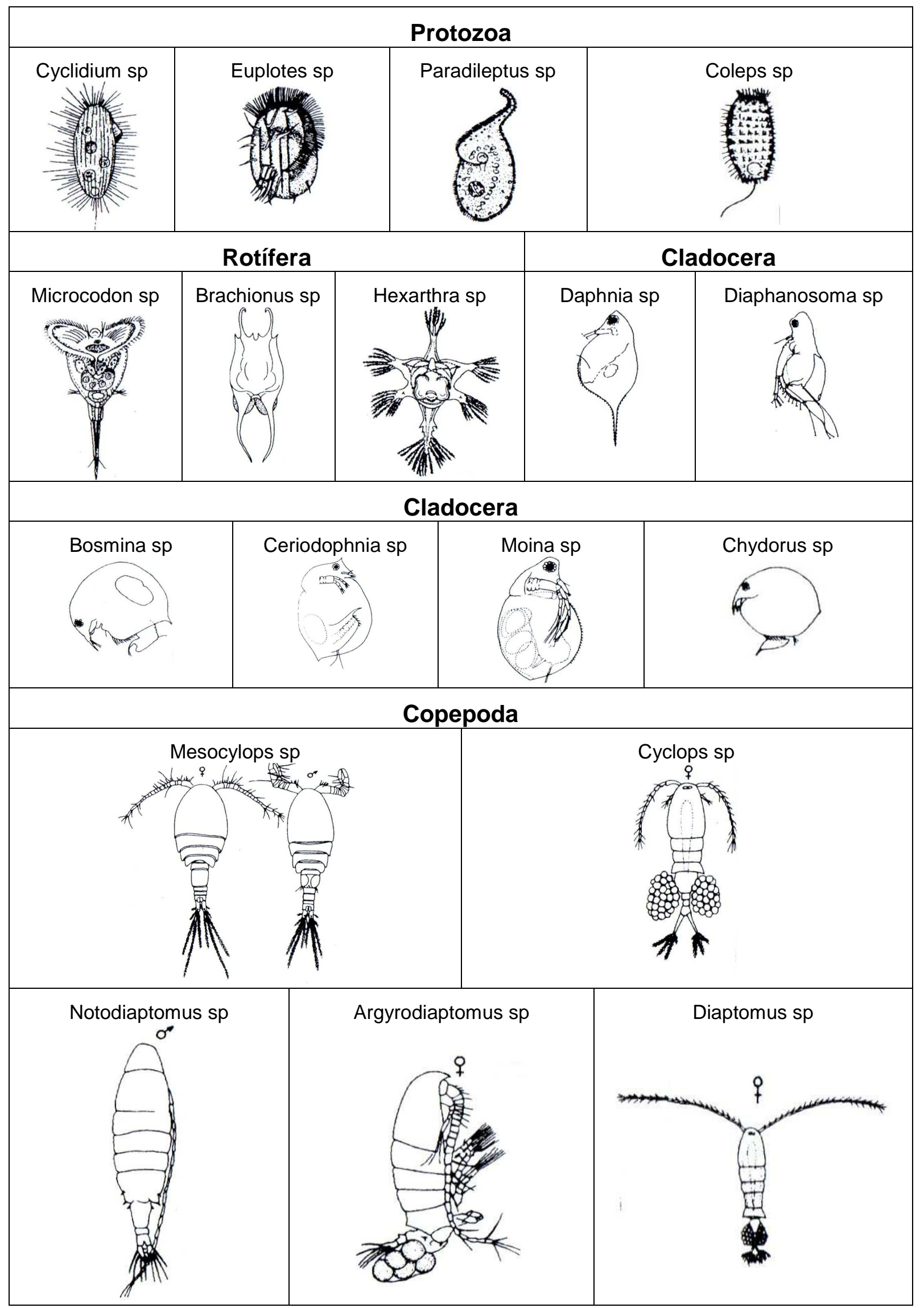

llustração 13 - Principais grupos taxonômicos do zooplâncton encontrados em ambientes aquáticos continentais. Fonte: Adaptado de Esteves (1998). 
c) Comunidade bentônica:

A comunidade bentônica é formada por animais (Zoobentos) e vegetais (Fitobentos), que habitam o sedimento aquático ou a superfície do sedimento. No caso do fitobentos, sua ocorrência fica limitada à ocorrência de luz para realização da fotossíntese, portanto, regiões mais profundas são mais pobres em fitobentos, bem como ambientes com elevada turbidez. Em ambientes aquáticos continentais a presença de materiais de origem vegetal no sedimento, como galhos e folhas são de grande importância como abrigo e fonte de alimento para organismos bentônicos (ESTEVES, 1998). A llustração 14, a seguir, mostra os principais organismos bentônicos encontrados em ambientes aquáticos continentais.

\begin{tabular}{|c|c|c|c|c|}
\hline \multicolumn{2}{|c|}{ Protozoa } & \multicolumn{2}{c|}{ Rotifera } \\
\hline Filo Ciliophora & Filo Sarcodina & Ordem Bdelloidea & Ordem Ploina \\
\hline Platyhelminthes & Nemathelminthes & \multicolumn{2}{c|}{ Annelida } & Crustacea \\
\hline Classe Turbellaria & & & & \\
\hline
\end{tabular}

llustração 14 - Principais grupos taxonômicos bentônicos encontrados em ambientes aquáticos continentais. Fonte: Adaptado de Esteves (1998). 


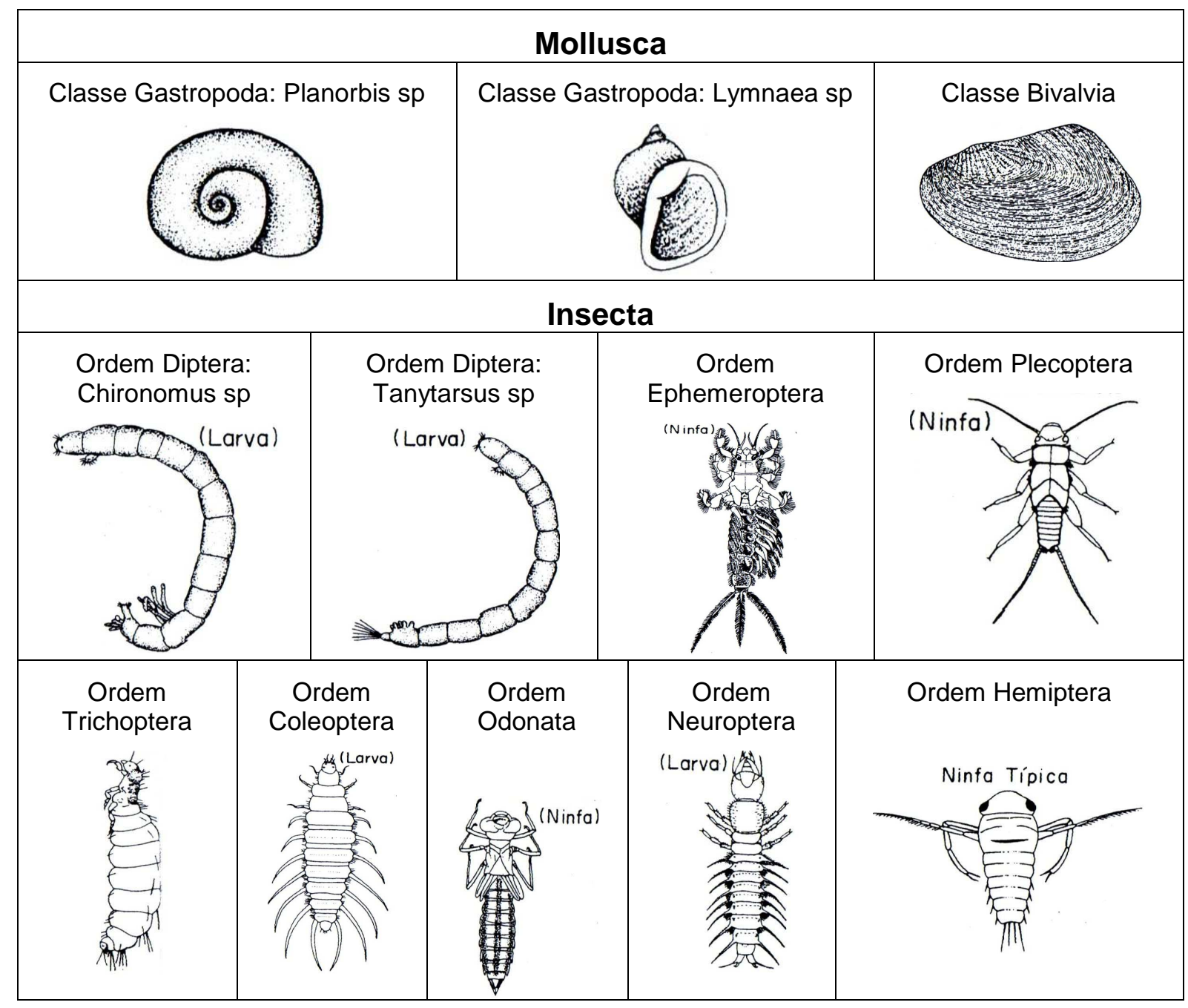

llustração 14 - Principais grupos taxonômicos bentônicos encontrados em ambientes aquáticos continentais. Fonte: Adaptado de Esteves (1998). (Continuação).

A Família Chironomidae da ordem Díptera merece atenção especial ao tratarmos de ambientes aquáticos, pois seus representantes tem participação significativa na composição destas comunidade, ocorrendo em elevada densidade no seu estágio larval, além disto, tal família é muito utilizada como bioindicadora, já que dentro dela há gêneros que são caracterizados por apresentarem elevada tolerância à poluição e outros por serem típicos de ambientes preservados. A elevada tolerância da larva Chironomidae às baixas taxas de oxigênio dissolvido na água, características comuns de corpos d'água impactados pelo lançamento de cargas orgânicas, devido ao aumento da atividade bacteriana que consome o oxigênio dissolvido rapidamente, se deve à presença de hemoglobina em alguns gêneros desta Família. A hemoglobina sintetizada por estes organismos tem alta 
afinidade por oxigênio, além da capacidade de armazenar oxigênio e o poupar para épocas de escassez, o que confere a estes organismos maior sucesso ecológico em condições de estresse ambiental ocasionada por alterações nas taxas de oxigênio do meio. Desta forma a identificação mais detalhada destes organismos permite um maior conhecimento a respeito da qualidade ambiental do ambiente em estudo (STRIXINO, 2011).

A llustração 15 mostra um esquema com dois morfotipos de larvas de Chironomidae. Neste esquema podemos observar a cabeça evidente, o corpo alongado e outros elementos característicos destes organismos.
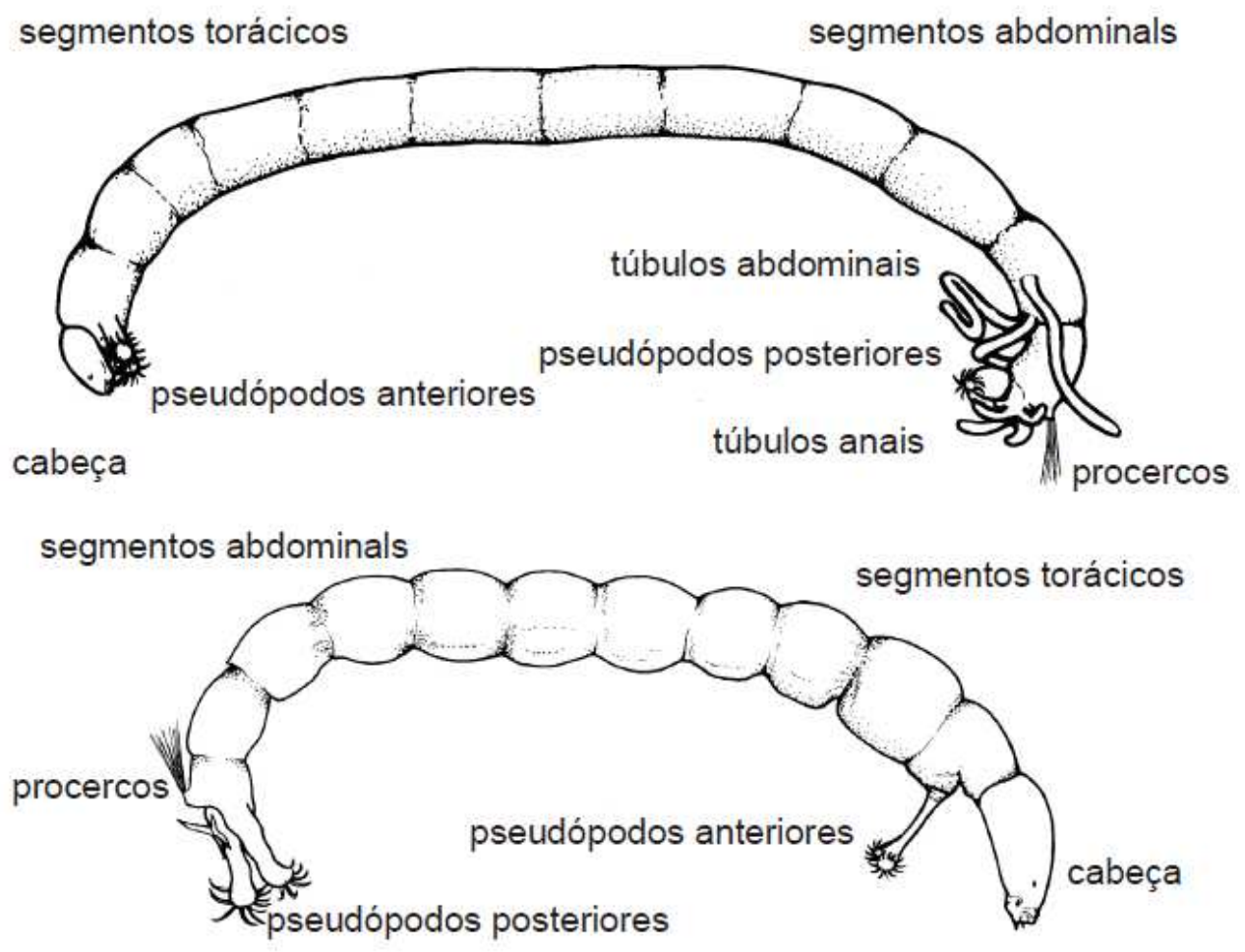

Ilustração 15 - Principais morfotipos da larva Chironomidae. Fonte: Strixino (2011).

Os principais representantes da família Chironomidae estão agrupados nas subfamílias Telmatogetoninae, Tanypodinae, Orthocladiinae e Chironominae, cujo grupo de maior interesse quando se trata de ambientes impactados é a tribo Chironomus, pois seus representantes possuem diversas especializações que conferem a eles maior resistência, como a presença de hemoglobina aumentando sua afinidade por oxigênio e permitindo seu armazenamento e túbulos anais alongados que aumentam sua capacidade de trocas gasosas e auxiliam na regulação osmótica (STRIXINO, 2011). 
A llustração 16 mostra um esquema com o ciclo de vida da família Chironomidae. No ambiente aquático este organismo habita o sedimento através da construção de galerias em "U" por onde secreta seus dejetos e captura seu alimento. Após completar sua metamorfose, passando pelo estágio de pupa, o organismo passa a habitar por um curto período de tempo o ambiente terrestre, onde se reproduz e deposita seus ovos através de uma massa ovígera no ambiente aquático, onde os indivíduos irão se desenvolver e retomar o ciclo (STRIXINO, 2011).

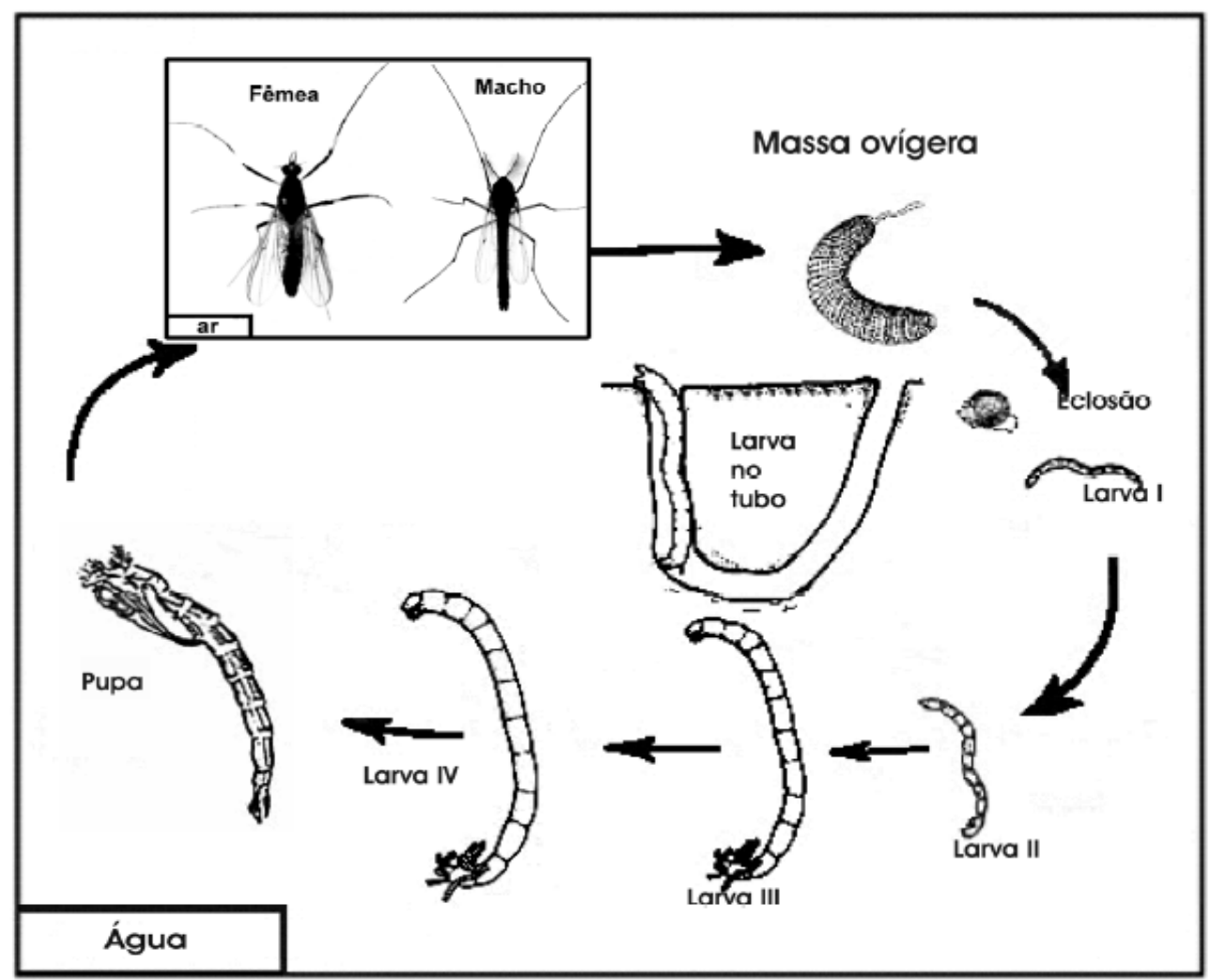

Ilustração 16 - Ciclo de vida da larva Chironomidae. Fonte: Strixino (2011).

\subsection{Indicadores biológicos}

Qualquer ecossistema tende a manter um equilíbrio através de relações ecológicas complexas, no entanto, tal equilíbrio não é estático e pode ser deslocado na ocorrência de mudanças nas características do meio, sejam elas causadas por agentes naturais ou pela ação antrópica. Quando tal equilíbrio é perturbado, o resultado é um reajuste na comunidade a fim de atingir um novo equilíbrio, tal ajuste gera uma mudança na dinâmica populacional, ou seja, há o beneficiamento dos organismos mais aptos à nova condição que se sobrepõe em número aos organismos menos aptos, além disso, pode haver a extinção local dos menos aptos 
ou não aptos. Tal mudança populacional no decorrer do tempo pode ser medida e utilizada como indicador biológico daquelas alterações.

Um dos principais elementos sensíveis à poluição dentro de um corpo d'água é sua biota, devido a isto é possível utilizá-la como indicador ambiental de poluição, já que uma mudança na dinâmica populacional de uma determinada espécie devido ao desequilíbrio ambiental pode refletir em como o ecossistema de modo geral se alterou (BRANCO, 1986). Para Rosenberg \& Resh (1993), um bom bioindicador deve:

- Ser sensível às alterações ambientais de maneira gradual e consiga expressar de maneiras detectáveis diferentes níveis de intensidade e magnitude deste impacto;

- Ser facilmente encontrado, facilmente identificado e existir em quantidade suficiente para viabilizar coletas;

- Apresentar baixo custo de processamento;

- Possuir ciclo de vida longo e responder espaço-temporalmente às alterações ambientais e

- Ser passível de uso em estudos ecotoxicológicos.

\subsection{Indicadores biológicos aplicados a ambientes aquáticos}

A adoção de uma única espécie como indicador biológico não é eficaz, já que a identificação no nível de espécie demanda tempo e a utilização de uma mesma espécie em duas áreas distintas nem sempre é possível, o que dificulta a comparação entre os dados obtidos. Deste modo torna-se mais vantajoso a aplicação de índices que avaliem a comunidade como um todo ou grupos de interesse (MAZZINI, 2007).

Para monitoramento de ecossistemas aquáticos vem sendo difundido o uso de macroinvertebrados bentônicos como bioindicadores (MORENO et al., 2009), já que sendo a grande maioria são filtradores ou predadores de filtradores, são eficientes no diagnóstico de alterações na qualidade da água. Além disso, estes organismos podem representar impactos ao longo de toda cadeia alimentar do sistema aquático, uma vez que eles são a principal fonte de alimento para a maior parte dos organismos deste ecossistema. Os índices de avaliação da qualidade do 
ambiente aquático são baseados em alguns conceitos ecológicos (BEGON et al., 2007), sendo eles:

- Riqueza: a abundância numérica de espécies de uma determinada comunidade ou região;

- Equitabilidade: o padrão de distribuição das espécies presentes em uma comunidade ou região;

- Diversidade: resultado da análise integrada da Riqueza e da Equitabilidade das espécies presentes em uma comunidade ou região; e

- Dominância: ocorrência da dominância numérica de uma espécie em uma comunidade ou região.

\subsection{POLUIÇÃO DA ÁGUA EM ÁREAS URBANAS}

A Lei Federal n.ํ 6.938/81 define poluição como sendo a degradação da qualidade ambiental resultante de atividades que direta ou indiretamente prejudiquem a saúde, a segurança e o bem-estar da população, além de serem ações que criem condições adversas às atividades sociais e econômicas, afetem desfavoravelmente a biota, afetem as condições estéticas ou sanitárias do meio ambiente e lancem matérias ou energia em desacordo com os padrões ambientais estabelecidos.

\subsubsection{Poluição por carga pontual e difusa}

A poluição que chega a um corpo d'água pode ser caracterizada em dois tipos: pontuais, que é o tipo de fonte passível de ser caracterizada e rastreada, como por exemplo, esgotos domésticos e efluentes industriais; e difusas, que são aquelas geradas de forma distribuída ao longo da bacia contribuinte, sendo elas produzidas por inúmeros agentes poluidores, que afluem aos corpos d'água preferencialmente por ocasião dos eventos de chuvas. A poluição difusa está diretamente relacionada com o tipo de uso e ocupação do solo, ou seja, à urbanização, práticas agrícolas, desmatamento e mineração. Em áreas rurais a carga de poluição difusa pode ser proveniente de atividades agrícolas; atividades pecuárias; silvicultura; chácaras de lazer e recreação. Já em áreas urbanas, ela pode ser gerada por residências, comércios, pólos industriais, complexos esportivos, parques, meios de transporte e 
resíduos atmosféricos (EIGER et al., 1999). Segundo Novotny (2003) os primeiros $40 \%$ de escoamento superficial podem conter $60 \%$ da carga poluidora.

Segundo Porto (1995) e Tomaz (2006) a poluição difusa é formada por diversas contribuições que são difíceis de detectar e quantificar, tais como freios de automóveis, resíduos de pneus, resíduos de pinturas em geral, fezes de animais, resíduos de ferro, zinco, cobre e alumínio de materiais de construção, deposição seca e úmida de particulados de hidrocarbonetos, restos de vegetação, derramamentos, erosão fuligem, poeira, enxofre, metais, pesticidas, nitritos e nitratos, cloretos, fluoretos silicatos, cinzas, compostos químicos e resíduos sólidos, entre outros. A llustração 17 apresenta as principais fontes poluidoras e tipos de poluentes gerados em áreas urbanas e seus arredores.

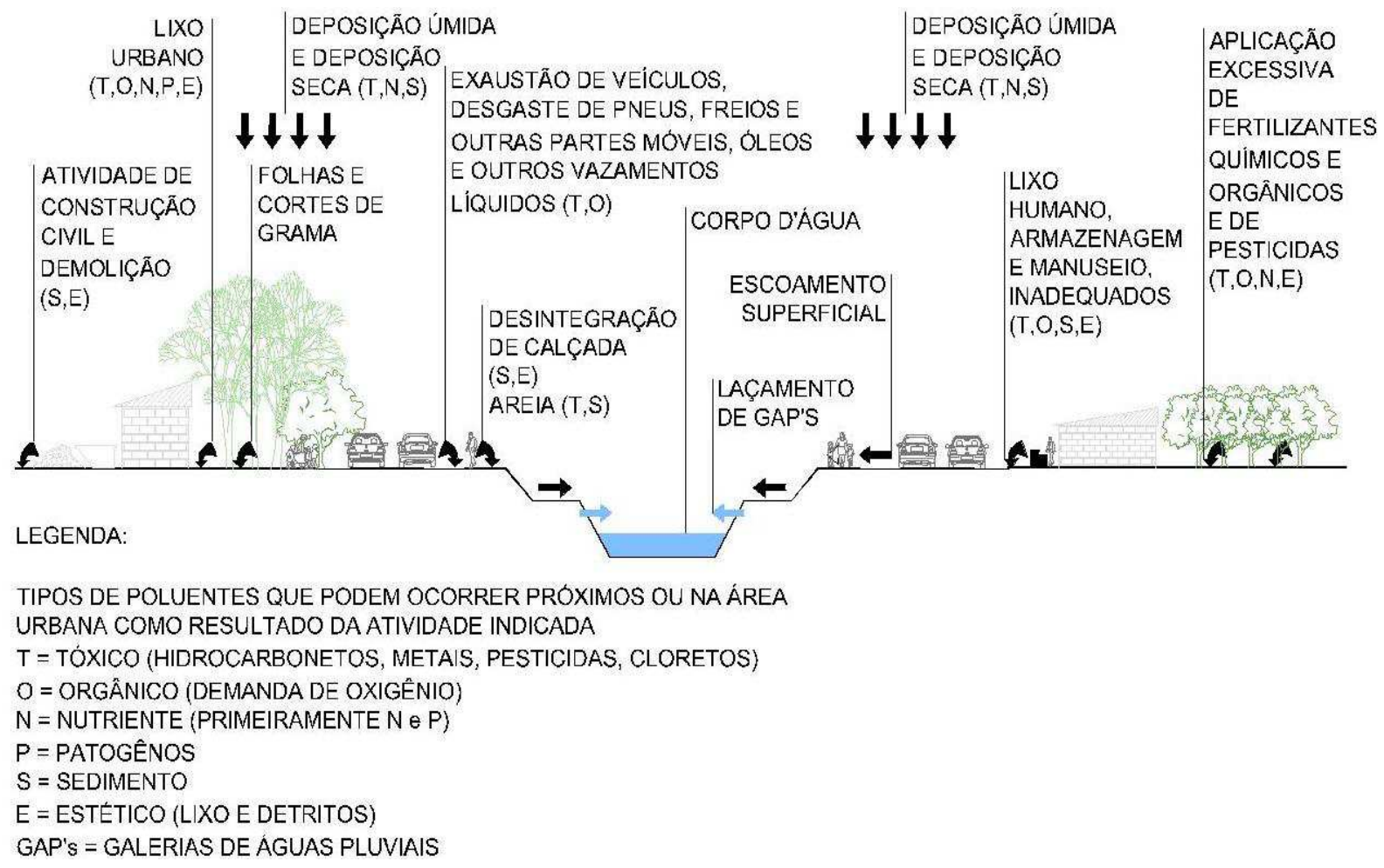

Ilustração 17 - Fontes de Poluição no Meio Urbano. Fonte: Elaborado pela autora a partir de WALESH (1989).

A poluição difusa está ligada diretamente ao tipo de ocupação do solo pelo homem, já que suas atividades geram poluição. A partir do momento em que o homem altera as características de uma bacia, a urbanizando, esta passa a contribuir para uma maior quantidade de sedimentos transportados para os corpos d'água. Uma das principais fontes de carga difusa é a atmosfera, já que nos 
primeiros instantes de precipitação há, grosso modo, a lavagem dos poluentes em suspensão na atmosfera, de modo que o destino final destes são os corpos d'água, tornando-se importante a observação desta fonte nas políticas de controle à poluição difusa; outro fator importante é o tipo de trafego viário presente nas vias da bacia, já que a frota viária é uma grande geradora de compostos orgânicos voláteis e de metais (NOVOTNY, 2003).

Os níveis de poluição difusa aumentam com a velocidade do escoamento, já que com o aumento da velocidade há também o aumento do potencial de arraste, portanto uma maior quantidade de poluentes será conduzida até os corpos d'água. O aumento da velocidade do escoamento em áreas urbanas é provocado principalmente pelo alto índice de impermeabilização do solo. Desta forma, a velocidade do escoamento superficial é maior que em condições de terreno natural, o que agrava o processo de arraste de partículas, fazendo com que mais resíduos sólidos cheguem aos corpos d'água e mais rapidamente (PORTO, 1995). Além disso, a velocidade do escoamento varia em função das características topográficas da bacia, deste modo bacias que apresentam altas declividades, a principio, apresentarão um maior potencial para geração de carga difusa do que bacias, que sobre as mesmas condições de ocupação e impermeabilização do solo, apresentem um terreno mais plano.

Em áreas urbanas a carga difusa tem papel significativo na poluição dos corpos d'água, de modo que estima-se que mesmo que $100 \%$ dos efluentes da região metropolitana de São Paulo fossem coletados e tratados, o rio Tietê ainda seria poluído em 25\% devido à poluição difusa proveniente do escoamento pluvial urbano. O fenômeno da poluição difusa é mais agravante em locais onde não há uma política efetiva de gestão de resíduos sólidos e onde a população desconhece a importância de gerenciar bem seus próprios resíduos sólidos, desta forma, fica evidente a importância da educação no processo e do interesse do poder público (TOMAZ, 2006).

Apesar da notória importância da influência da carga difusa, o problema da poluição dos corpos d'água sempre se popularizou em torno das fontes de poluição pontuais, o que localiza o problema e não exige um manejo integrado de toda a bacia hidrográfica, mas em locais onde a poluição por fontes pontuais já é uma 
realidade do passado a preocupação com a poluição difusa vem crescendo e demandando estudos para quantificá-la, avaliá-la e eliminá-la. É o caso dos EUA, que vem aprimorando seus esforços para o controle de cargas difusas com investimentos maciços nesse setor desde 1993 (PORTO, 2002).

O inicio da preocupação com a poluição difusa se dá com a institucionalização da Agência de Proteção Ambiental dos Estados Unidos (USEPA), na década 1970, quando surgem as primeiras pesquisas relacionadas com a poluição difusa urbana; porém este tema já vinha sendo estudado a partir do século XIX na Europa. Já no Brasil, a temática começou a ser abordada em algumas cidades brasileiras a partir da década de 1990 (PRODANOFF, 2005).

O controle da poluição difusa, apesar de mais notório em locais onde já há uma política efetiva de controle de cargas pontuais, deve ser implantado em qualquer área urbana, sendo importante que haja uma popularização do assunto para que não só o meio acadêmico tome conhecimento do tema, como também a sociedade como um todo, já que a história nos mostra que nem sempre o que achamos desnecessário o é de fato, e muitas vezes a realização de uma intervenção precoce evita transtornos maiores no futuro.

\subsubsection{Controle da carga difusa}

Segundo Novotny e Olem (1994) o controle da carga difusa pode ser realizado através de medidas não estruturais e estruturais. As medidas não estruturais, conhecidas como Best Management Practices - BMP's - são caracterizadas como sendo medidas de baixo custo, pois não exigem a implantação de estruturas físicas e localizadas, mas sim ações de gestão e gerenciamento por toda bacia. As principais medidas não estruturais são aquelas que visem organizar a participação da população da bacia, garantindo uma eficiente gestão de resíduos; controlem o uso e ocupação do solo, prevenindo a ocupação de áreas sensíveis; e que promovam a manutenção de áreas permeáveis, promovendo a infiltração e resultando na redução da vazão de pico.

As medidas estruturais demandam maior custo e estão ligadas a intervenções físicas, como exemplo: 
a) Pavimento drenante: Pavimento que promova a infiltração de parcela do escoamento superficial, como os modulares (Intertravados), porosos (Concreto ou asfalto sem agregados finos) e as britas;

b) Trincheiras de infiltração: Valas rasas, revestida por mata geo-têxtil e preenchidas com material granular que atuam como sistema de drenagem, fazendo com que a carga difusa fique retida no solo. A llustração 18 mostra o detalhe desta estrutura (SOUZA, 2000);

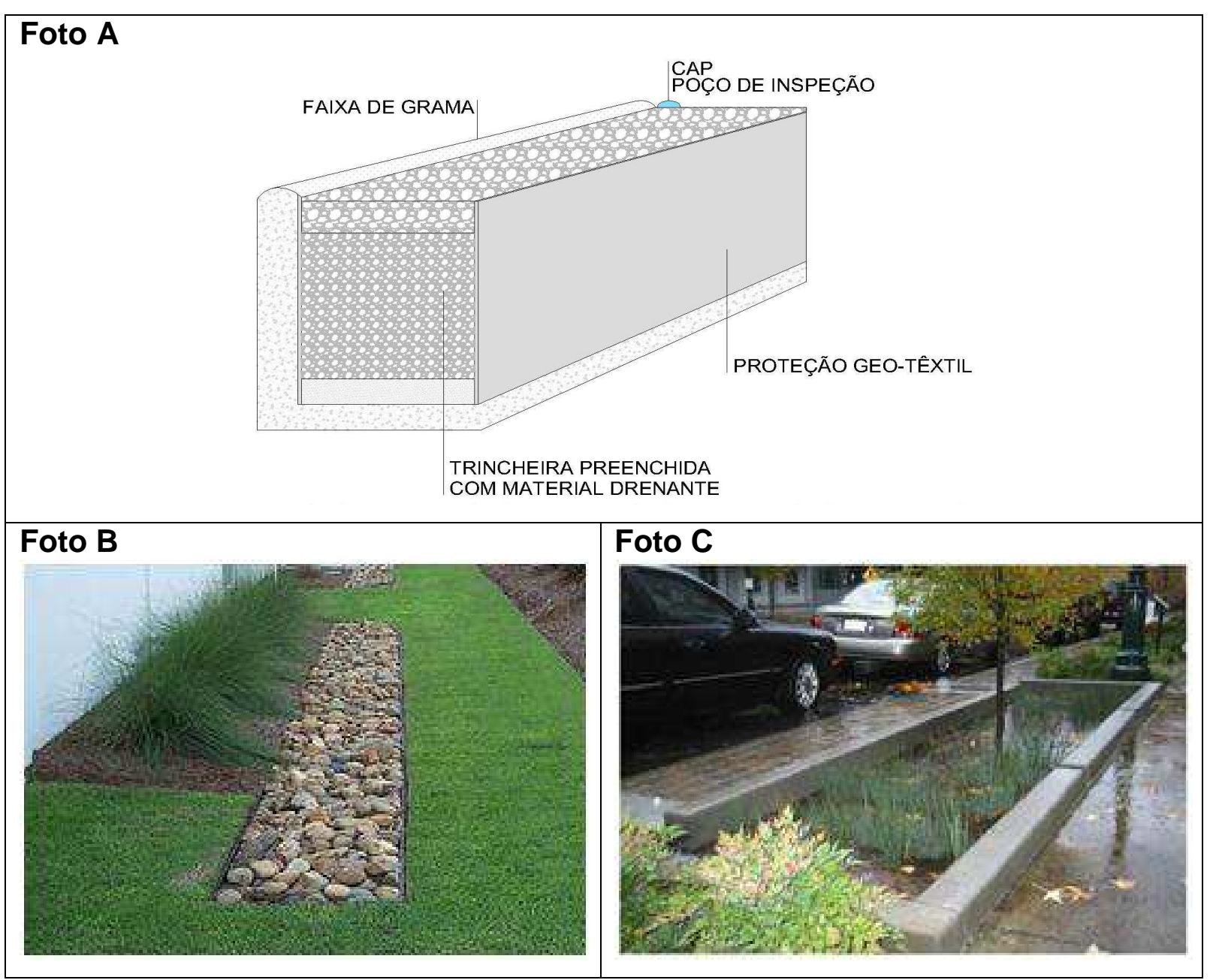

Ilustração 18 - Medidas estruturais - Trincheiras de Infiltração: Foto A: Detalhe construtivo de uma trincheira de infiltração (Adaptado pela autora de SOUZA, 2002). Fotos B e C: Trincheiras de infiltração implantadas (UFSM, s/d).

c) Filtro grama: Faixa de vegetação ao longo das margens dos canais da bacia a fim de promover a infiltração do escoamento superficial, filtração do material particulado e diminuição do runoff (TOMAZ, 2006); 
d) Bacias de retenção alagadas (wet ponds ou wet reservoir): Lagos permanentes, que retém a água das chuvas durante todo 0 ano a fim de promover 0 amortecimento das vazões de pico e a melhoria da qualidade da água através da remoção de poluentes por atividade biológica e por decantação no fundo do lago (USEPA, s/d);

A llustração 19 mostra a aplicação do Filtro Grama, na Foto A e B, e de Wet Ponds nas Fotos C e D.

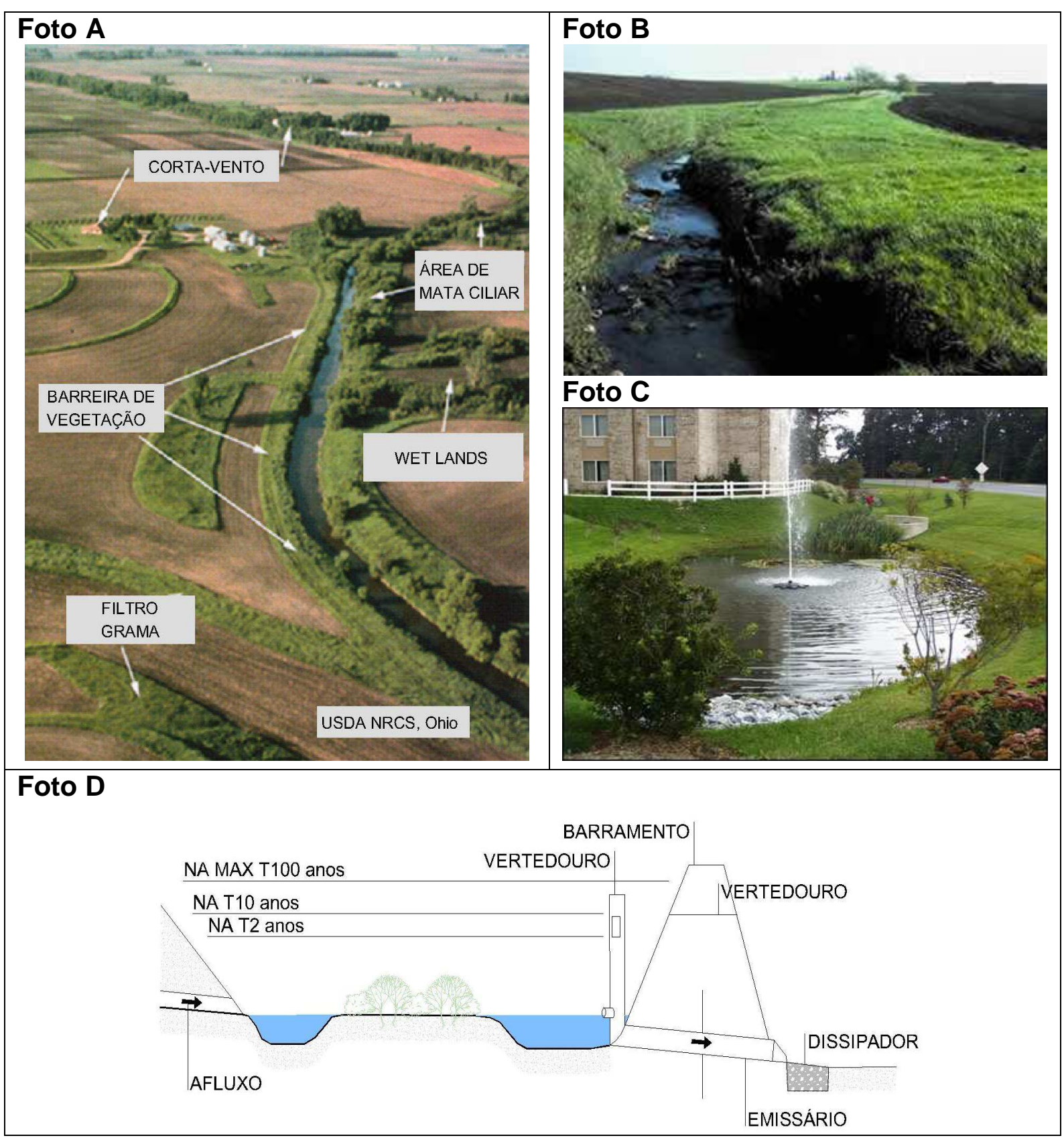

Ilustração 19 - Medidas estruturais - Filtro Grama e Wet Ponds: Foto A: Estruturas de retenção e detenção em um rio na zona agrícola de Ohio-EUA (MDA, s/d). Foto 
B: Filtro Grama (MDA, s/d). Foto C: Wet Ponds (DNREC, s/d). Foto D: Wet Ponds (Adaptado pela autora de USEPA, s/d).

e) Wetlands: São áreas que estão permanentemente alagadas, ou seja, saturadas. Podem ser naturais, como brejos, mangues, várzeas e pântanos; ou artificiais, construídas pelo homem com duas finalidades possíveis, a primeira aplicada ao tratamento secundário de esgotos; já a segunda aplicada no controle da carga difusa. Tal controle da carga difusa se dá através da ação física (Infiltração e decantação), químicos (Adsorção) e biológicos (Ação de microorganismos e da vegetação presente no microambiente) (TOMAZ, 2006).

f) Bacias de detenção: reservam a água por determinado período e a liberam logo após o evento de chuva. Um exemplo de aplicação destas estruturas são os piscinões brasileiros;

g) Filtros de areia de superfície: Destinado ao tratamento dos primeiros instantes de chuva, que carregam a maior parte da carga difusa, possuindo quatro elementos principais, um regulador de fluxo que conduz o fluxo para o sistema de tratamento; um sistema de pré-tratamento que retém folhas e material grosseiro, sedimentos, óleos e graxas; Tratamento do material fino; e uma estrutura para regulação da saída. Esta estrutura deve ser construída preferencialmente off-line, ou seja, sem conexão direta com o corpo d'água (TOMAZ, 2006).

Outra importante ferramenta de controle da carga difusa é a varrição de rua. No entanto, não é o bastante para a eliminação total da carga difusa, pois sua eficiência na eliminação da carga poluidora no escoamento superficial é pouco significativa à medida que esta remove principalmente os sólidos grosseiros. Uma varrição com alto rendimento reduz cerca de: $25 \%$ do material fino, $50 \%$ do mediano e $75 \%$ do grosseiro; resultando na redução de poluentes no escoamento superficial efetiva de apenas 15\%. (NOVOTNY et al. 1985). O Gráfico apresentado na llustração 20, a seguir, mostra o resultado de um modelo para avaliação da eficiência da varrição na eliminação de poluentes no escoamento. 


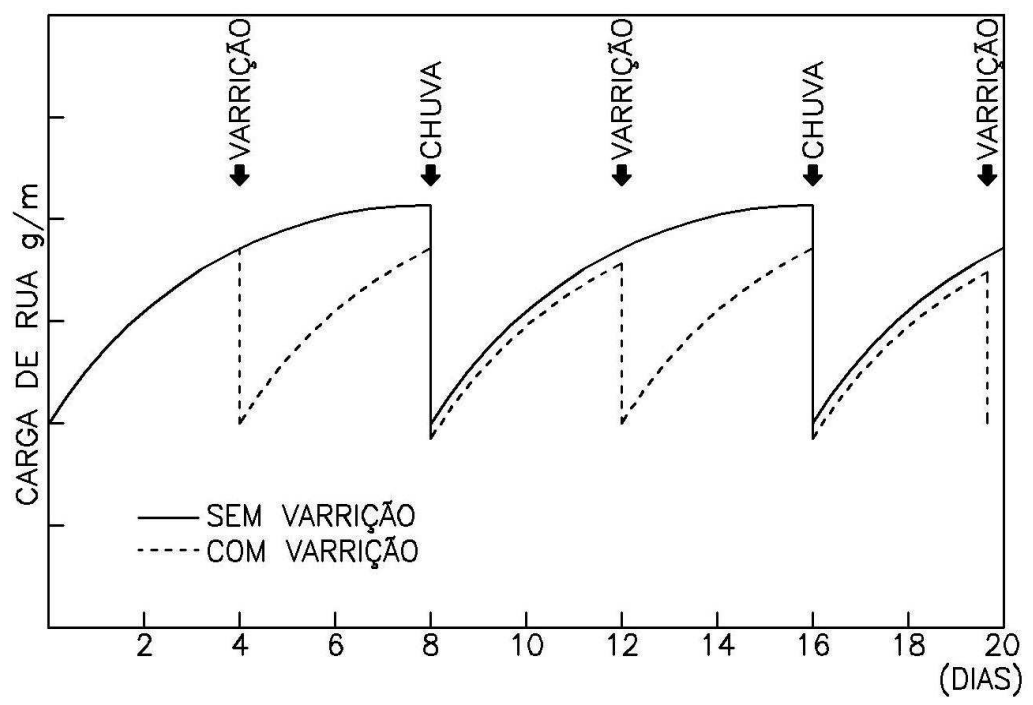

Ilustração 20 - Ilustração Simplificada do efeito de redução da carga de poluição no escoamento provocado pela varrição - Fonte: Adaptado de Novotny et al. (1985).

\subsubsection{Quantificação da carga difusa}

Existem diversas maneiras de quantificar cargas difusas, dentre elas Novotny (2003) destaca dois tipos, sendo eles: o método da Unidade de Carga (UC) e a da Concentração Média de Evento (CME). Com o método de Unidade de Carga, é possível determinar cargas diárias ou anuais de bacias com diferentes tipos de ocupação do solo, mas não considera os mecanismos de transporte da carga. Já o segundo método, da Concentração Média de Evento (CME), avalia os impactos causados pela carga difusa no corpo d’água pelo monitoramento das variáveis de qualidade de água do corpo. No item seguinte será descrito em detalhe a aplicação do método da Unidade de Carga, uma vez que este método será o aplicado no estudo de caso.

\subsection{Unidade de carga}

Carga poluente é a quantidade de poluente, em massa ou peso, transportada, em uma unidade de tempo, a partir da fonte poluente até o corpo d'água. A estimativa das cargas poluentes que chegam a um corpo d'água é um elemento crucial para o desenvolvimento de planos de gestão de bacias hidrográficas, pois com base nestas estimativas é possível estabelecer limites para estas cargas, como por exemplo, através da adoção de um programa de carga máxima diária total (CMDT) (USEPA, 2003). 
A unidade de carga representa a contribuição de poluentes por unidade de área e de tempo de cada tipo de ocupação do solo em uma determinada bacia hidrográfica. $\mathrm{O}$ método possui um grande ponto positivo no que se refere a facilidade na sua aplicação, no entanto existem desafios, pois nem sempre se dispõe de bons dados para realizar a alimentação do modelo (USEPA, 2003). O método consiste em atribuir pesos de produção de carga difusa para cada tipo de uso do solo, através da consulta a valores de referência obtidos através da análise da carga produzida pelo escoamento superficial.

O projeto Guarapiranga, estudo pioneiro no que se refere a cargas difusas no Brasil, realizado pela SMA de São Paulo e a empresa Prime Engenharia, contemplou a quantificação das cargas poluentes aportadas para o reservatório através da aplicação do modelo MQUAL (Modelo matemático de Correlação Uso do Solo x Qualidade da Água). O programa é alimentado por uma matriz de coeficientes de exportação de cargas para Fósforo total, Nitrogênio total, DBO, Sólidos em suspensão e Coliformes totais de diversos tipos de atividades, conforme mostrado na Tabela 06, a seguir (SMA/Prime Engenharia, 1998).

Tabela 06 - Matriz de coeficientes de exportação de cargas. Fonte: Adaptado de SMA/Prime Engenharia (1998).

\begin{tabular}{|c|c|c|c|c|c|c|c|}
\hline \multicolumn{8}{|c|}{ Matriz de coeficientes de exportação de cargas } \\
\hline Fonte & Unidade & $\begin{array}{l}\text { Fósforo } \\
\text { Total }\end{array}$ & $\begin{array}{c}\text { Nitrogênio } \\
\text { Total }\end{array}$ & DBOc & DBOn & $\begin{array}{l}\text { Sólidos em } \\
\text { Suspensão }\end{array}$ & $\begin{array}{c}\text { Coliformes } \\
\text { Totais }\end{array}$ \\
\hline Atividade Agrícola & $\mathrm{kg} / \mathrm{km}^{2}$. dia & 0,346 & 2,95 & 7,564 & 7,315 & 230 & $1,00 \mathrm{E}+11$ \\
\hline Reflorestamento & $\mathrm{kg} / \mathrm{km}^{2}$. dia & 0,039 & 0,6 & 1,302 & 1,197 & 20 & $1,00 \mathrm{E}+08$ \\
\hline Mata / Capoeirão & $\mathrm{kg} / \mathrm{km}^{2}$. dia & 0,039 & 0,6 & 1,302 & 1,197 & 20 & $1,00 \mathrm{E}+08$ \\
\hline Capoeira / Campo & $\mathrm{kg} / \mathrm{km}^{2}$. dia & 0,028 & 0,5 & 1,079 & 1,064 & 30 & $1,00 \mathrm{E}+08$ \\
\hline Chácaras & $\mathrm{kg} / \mathrm{km}^{2}$. dia & 0,05 & 0,9 & 2 & 2,25 & 40 & $1,00 \mathrm{E}+09$ \\
\hline Áreas Urbanas - Padrão Superior & $\mathrm{kg} / \mathrm{km}^{2} . \mathrm{dia}$ & 0,034 & 1,274 & 4 & 5,535 & 50 & $1,00 \mathrm{E}+09$ \\
\hline Áreas Urbanas - Padrão Inferior & $\mathrm{kg} / \mathrm{km}^{2}$. dia & 0,135 & 2,548 & 8 & 11,07 & 100 & $1,00 \mathrm{E}+09$ \\
\hline $\begin{array}{l}\text { Áreas de Uso Industrial e } \\
\text { Comercial }\end{array}$ & $\mathrm{kg} / \mathrm{km}^{2} \cdot \mathrm{dia}$ & 0,081 & 1,784 & 5,6 & 7,749 & 70 & $1,00 \mathrm{E}+09$ \\
\hline $\begin{array}{l}\text { População com lançamento direto } \\
\text { de esgotos nos corpos de água }\end{array}$ & kg/hab.dia & 0,00093 & 0,00775 & 0,0228 & 0,0354 & 0,0275 & $3,60 \mathrm{E}+10$ \\
\hline $\begin{array}{l}\text { População de áreas urbanizadas } \\
\text { com sistema individual de } \\
\text { diposição de esgotos - Alta } \\
\text { Densidade }\end{array}$ & kg/hab.dia & 0,00079 & 0,00659 & 0,0148 & 0,0337 & 0,01375 & $1,80 \mathrm{E}+10$ \\
\hline $\begin{array}{l}\text { População de áreas urbanizadas } \\
\text { com sistema individual de } \\
\text { diposição de esgotos - Baixa } \\
\text { Densidade }\end{array}$ & kg/hab.dia & 0,0006 & 0,00388 & 0,0057 & 0,0177 & 0 & $1,80 \mathrm{E}+09$ \\
\hline
\end{tabular}


Steinke (2007), com base na matriz de coeficientes de exportação de cargas do sistema MQUAL, calculou a carga difusa produzida por alguns tipos de uso do solo, apresentadas na Tabela 07, a seguir.

Tabela 07 - Matriz de coeficientes de exportação de cargas difusas. Fonte: Adaptado de Steinke (2007).

\begin{tabular}{|l|c|c|c|c|}
\hline \multicolumn{5}{|c|}{ Matriz de coeficientes de exportação de cargas difusas } \\
\hline \multicolumn{1}{|c|}{ Fonte } & Unidade & $\begin{array}{c}\text { Fósforo } \\
\text { Total }\end{array}$ & $\begin{array}{c}\text { Nitrogênio } \\
\text { Total }\end{array}$ & $\begin{array}{c}\text { Sólidos em } \\
\text { Suspensão }\end{array}$ \\
\hline Urbano & $\mathrm{kg} / \mathrm{km}^{2}$. dia & 0,034 & 1,274 & 50,000 \\
\hline Agricultura & $\mathrm{kg} / \mathrm{km}^{2}$. dia & 0,346 & 2,950 & 230,000 \\
\hline Campo & $\mathrm{kg} / \mathrm{km}^{2}$. dia & 0,028 & 0,500 & 30,000 \\
\hline Campo/Pastagem & $\mathrm{kg} / \mathrm{km}^{2}$. dia & 0,028 & 0,500 & 30,000 \\
\hline Campo/Mata & $\mathrm{kg} / \mathrm{km}^{2}$. dia & 0,039 & 0,600 & 20,000 \\
\hline Mata & $\mathrm{kg} / \mathrm{km}^{2}$. dia & 0,039 & 0,600 & 20,000 \\
\hline
\end{tabular}

Com base nos coeficientes definidos para calibração do método, o passo seguinte é a quantificação do uso do solo existente na bacia com base em imagens aéreas da bacia em escala adequada e visitas à área. Assim após a quantificação das áreas de cada tipo de uso do solo na bacia é possível obter a produção periódica de carga difusa. A llustração 21 demonstra a aplicação do método.

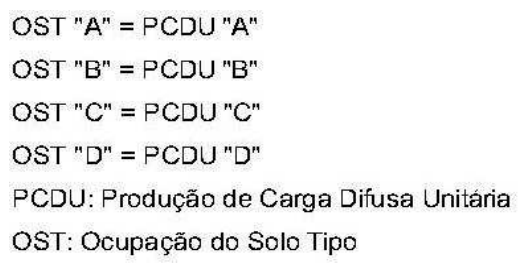

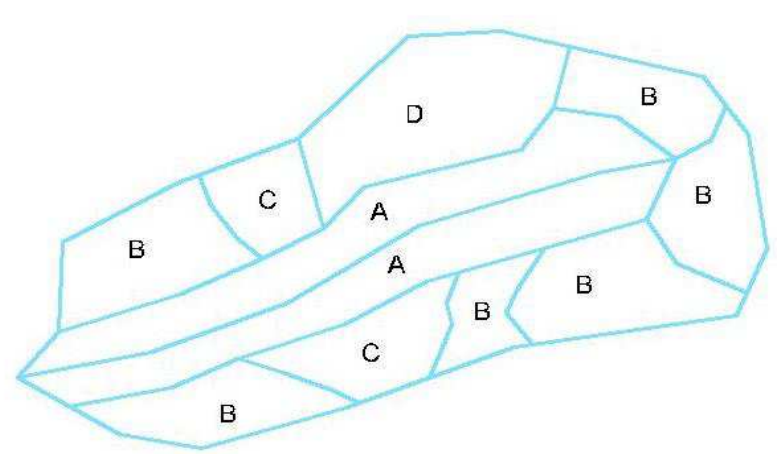

PRODUÇÃO TOTAL DE CARGA DIFUSA DO SOLO TIPO "A" DA BACIA = PCDU "A" $\times Y$ PRODUÇÃO TOTAL DE CARGA DIFUSA DO SOLO TIPO "B" DA BACIA = PCDU "B" $\times \mathrm{K}$ PRODUÇÃO TOTAL DE CARGA DIFUSA DO SOLO TIPO "C" DA BACIA $=$ PCDU "C" $\times Z$ PRODUÇÃO TOTAL DE CARGA DIFUSA DO SOLO TIPO "D" DA BACIA = PCDU "D" $\times$ W

EXEMPLO:

OST "TECIDO URBANO CONTINUO" $=51,31 \mathrm{Kg} / \mathrm{Km} 2 /$ dia

ÁREA TOTAL DA OCUPAÇÃO DO SOLO TIPO "TECIDO URBANO CONTINUO" $=1,0 \mathrm{Km} 2$

PRODUÇÃO TOTAL DE CARGA DIFUSA DO SOLO TIPO "TECIDO URBANO CONTINUO" DA BACIA $=51,31 \times 1,0=51,31 \mathrm{Kg} / \mathrm{dia}$

Ilustração 21 - Metodologia de aplicação do método da Unidade de Carga. Fonte: Elaborado pela autora. 


\section{ESTUDO DE CASO}

Para avaliação do processo de recuperação de corpos d'água e melhor entendimento da interferência no processo causada pela carga difusa, faz-se necessário a utilização de corpos d'água livres de cargas pontuais. Para tanto foram utilizados como objeto de estudo córregos de interesse do programa "Córrego Limpo". Foram selecionados dois corpos d'água do programa, cujas bacias possuem características semelhantes, sendo eles o Córrego lbiraporã e a Nascente do Córrego do Sapé, para quantificação da produção de carga difusa e comparação do processo de recuperação em cada um deles com base no histórico do monitoramento da $\mathrm{DBO}_{5,20}$ realizado pela SABESP. A llustração 22 mostra a localização das áreas de estudo, bem como os principais pontos de acesso a elas.

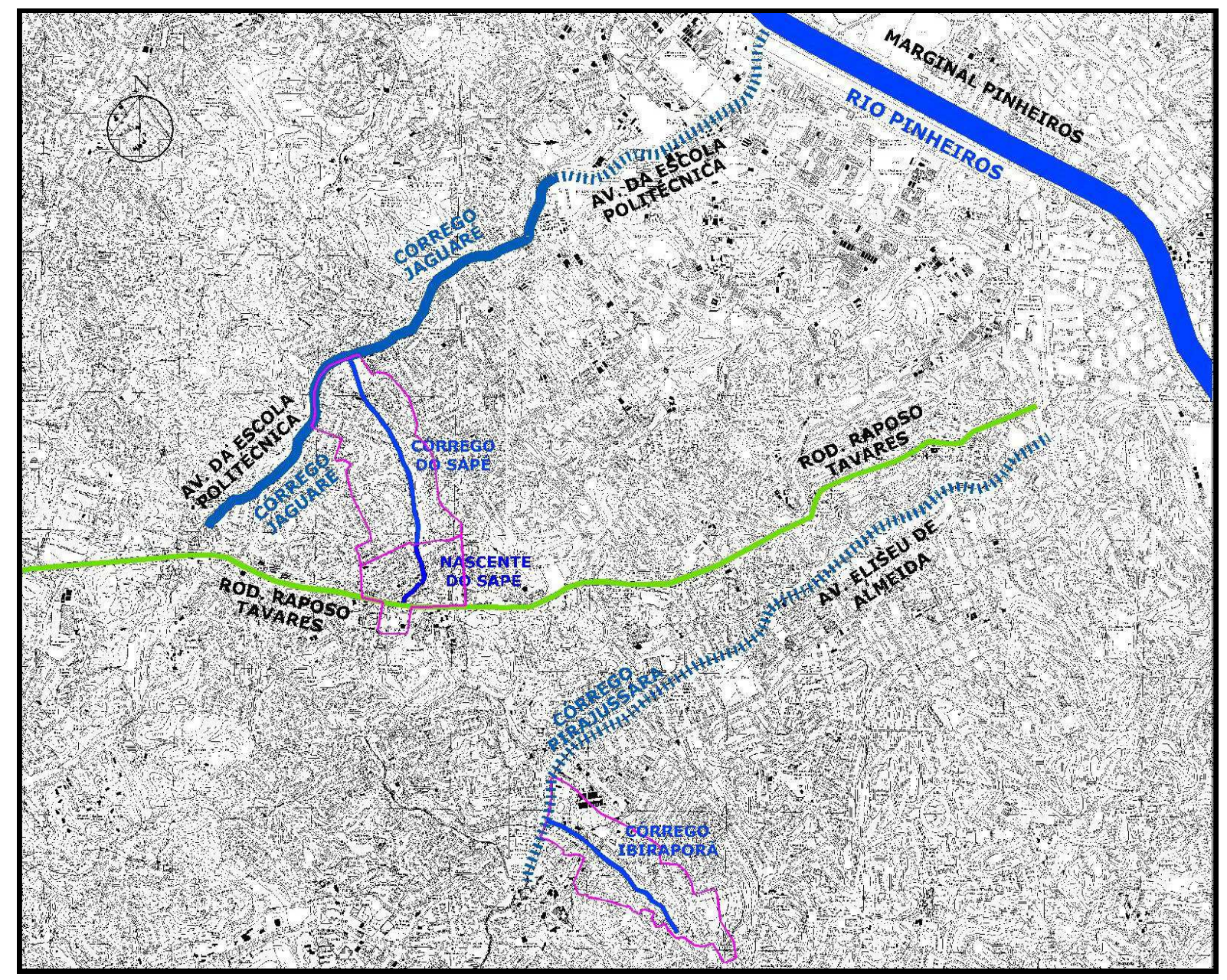

llustração 22 - Córrego do Sapé e Córrego Ibiraporã - Localização e acesso. Fonte: Elaborado pela autora. 
Além disso, os dois corpos d'água foram objeto de duas outras frentes investigativas. A primeira, com foco no Córrego do Sapé e no processo de reintegração do córrego à paisagem através da criação do parque linear em suas margens, analisando o processo de urbanização da favela presente em suas margens bem como as obras de canalização do canal; e a segunda, com foco no Córrego lbiraporã e na influência da carga difusa no processo de recuperação deste, avaliando também a influência do programa de gestão colaborativa na consolidação do processo de despoluição. No primeiro caso, para embasamento da discussão foram utilizadas analises do histórico fotográfico de todo o processo e informações obtidas junto à secretária da habitação de São Paulo - SEHAB - e à SABESP. No segundo caso, foi necessária a realização do monitoramento físico-químico no período seco e chuvoso e aplicação de indicadores biológicos para caracterização da qualidade das águas do corpo d'água nos dois momentos; Além disso, foram utilizadas informações obtidas junto à SABESP sobre o programa de governança colaborativa implantado em sua bacia. Os itens seguintes apresentam a caracterização detalhada das duas áreas em questão.

\subsection{CÓRREGO DO SAPÉ}

\subsubsection{Caracterização da área}

O córrego do Sapé pertencente à bacia do Jaguaré, localizado na subprefeitura do Butantã, tem como principais pontos de acesso à área a Avenida da Escola Politécnica, a Avenida do Rio Pequeno e a Rodovia Raposo Tavares. A nascente do córrego fez parte da primeira etapa do programa "Córrego Limpo" no ano de 2009, tal etapa contemplou a realização de $132 \mathrm{~m}$ de redes coletoras e 119 metros de travessia da Rodovia Raposo Tavares, o investimento feito para despoluição deste trecho foi de 250 mil reais e beneficiou uma população de cerca de $16 \mathrm{mil}$ habitantes. O trecho seguinte possui em suas margens a favela do Sapé, que atende hoje uma população de cerca de 10mil habitantes e atualmente está passando por diversas intervenções que resultarão na urbanização e regularização da área. A despoluição deste segundo trecho do córrego está prevista para a terceira etapa do programa no período de janeiro de 2012 a meados de 2013 (CÓRREGO LIMPO, s/d). As intervenções para urbanização e regularização da área em conjunto com as intervenções do programa "Córrego Limpo" resultarão na 
criação do Parque Linear do Sapé que será caracterizado em detalhe nos itens seguintes. A llustração 23 mostra a bacia do córrego do Sapé e a divisão em Trecho 1 e 2, além disso é possível visualizar o ponto de amostragem para analise da $\mathrm{DBO}_{5,20}$, no trecho já contemplado, realizada pela SABESP e o estaqueamento para localização do memorial fotográfico.

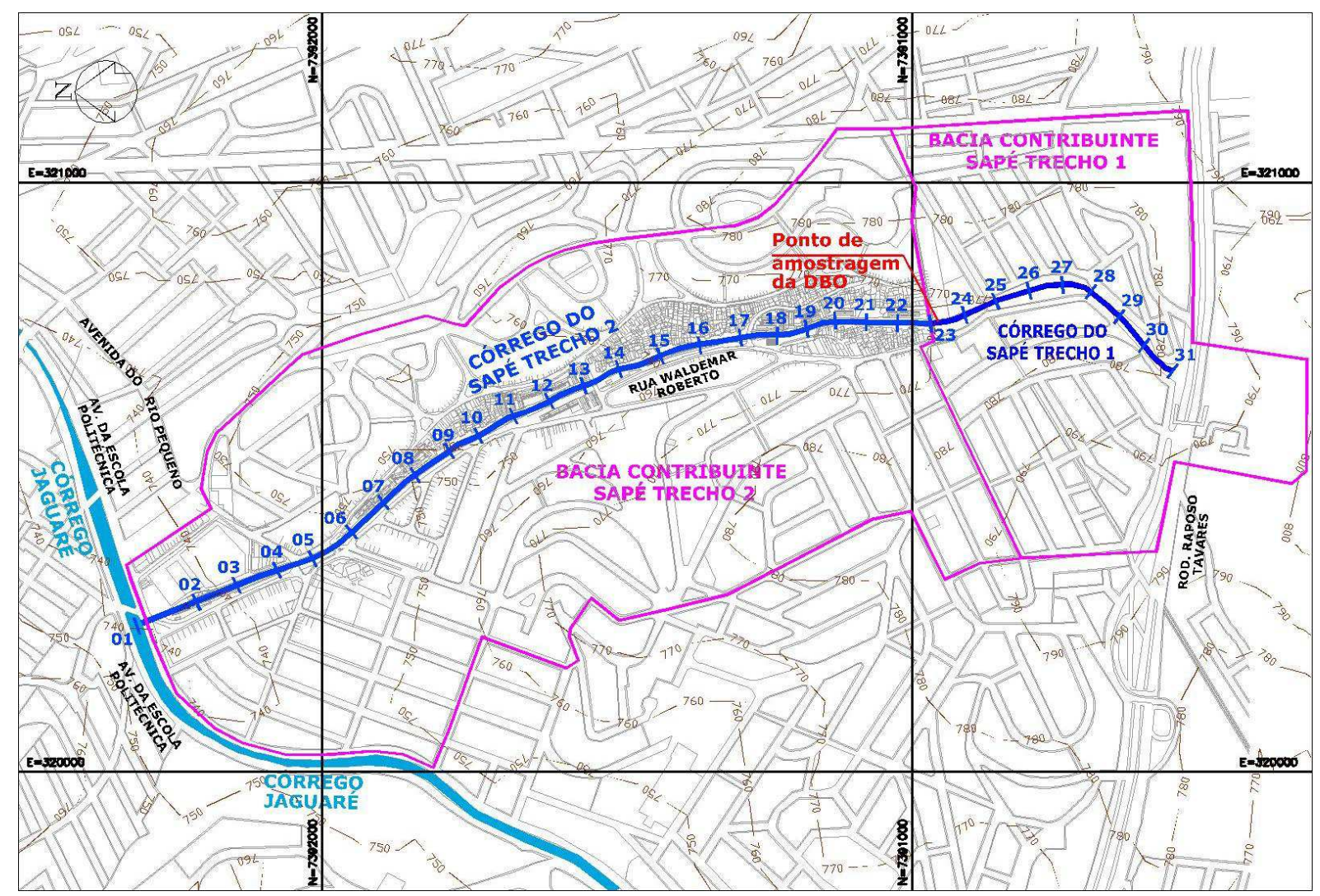

Ilustração 23 - Córrego do Sapé: Bacia contribuinte. Fonte: Elaborado pela autora.

\subsubsection{Processo de recuperação}

Através do registro fotográfico (Cortesia de Andréia Sandrini - Coordenadora das ações do Programa "Córrego Limpo" na Zona Oeste) realizado desde o inicio do processo foi possível realizar comparações visuais entre a situação antes e depois das intervenções do programa e das obras para implantação do parque linear no primeiro trecho do canal, além disso, foram realizadas visitas à área da nascente, onde foi possível constatar a situação atual do corpo d'água. A llustração 24 , a seguir, mostra um trecho do canal (Estaca 24 a 26) pertencente ao trecho 1, referente à nascente do Sapé, em 12/08/2008 antes (Foto A) e em 17/02/2012 depois da canalização proposta pelo projeto do parque linear implantado às margens deste primeiro trecho do canal e das intervenções do programa. 


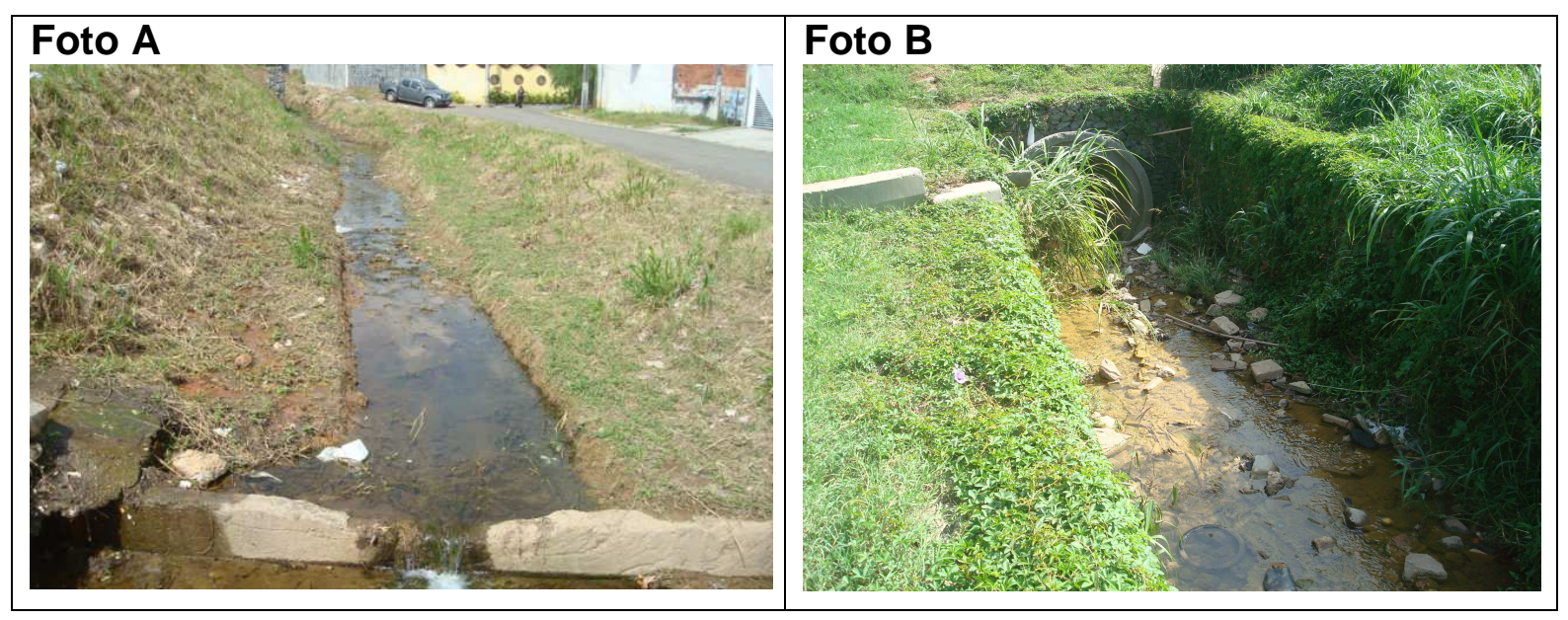

Ilustração 24 - Nascente do Sapé: Detalhe do canal em 12/08/2008 (Foto A) e em 17/02/2012 (Foto B). Fonte: Cortesia de Andréia Sandrini - Coordenadora das ações do programa "Córrego Limpo" na Zona Oeste.

Este tipo de regularização traz como beneficio imediato um aumento da segurança no que se refere ao risco de alagamentos de áreas marginais ocupadas provocados por enchentes, o aumento temporário do nível d'água do canal de ocorrência sazonal; ou inundações, o extravasamento do NA máximo do canal, que faz com que suas águas passem a ocupar áreas marginais, tal fenômeno tem menor frequência em ambientes naturais, mas em áreas urbanas tem essa frequência aumentada devido à fatores como a impermeabilização do solo (CANHOLI, 2005). A Ilustração 25 mostra duas seções do Córrego do Sapé na Estaca 25, antes e depois da canalização, onde podemos observar a maior suscetibilidade ao alagamento das áreas marginais antes da canalização.

Antes da Canalização:

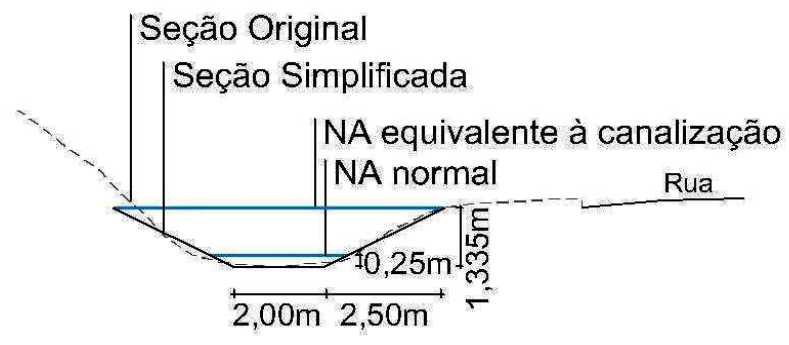

Seção Trapezoidal:

Área $=((B+b) / 2) \times h$

Área $=((2,00+7,00) / 2) \times 1,335=6,00 \mathrm{~m}^{2}$
Após a Canalização:

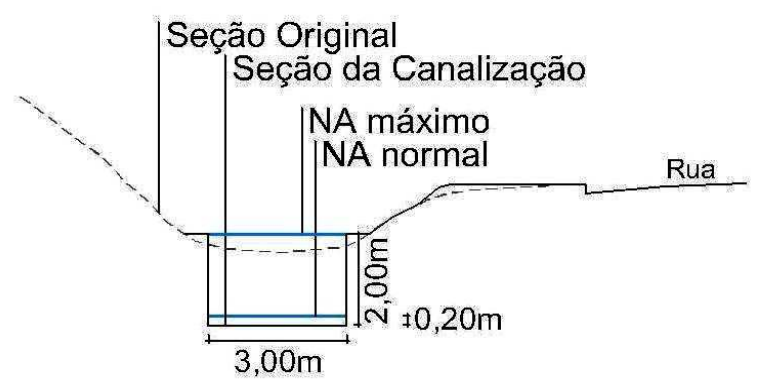

Seção Retangular:

Área $=\mathrm{b} \times \mathrm{h}$

Área $=3,00 \times 2,00=6,00 \mathrm{~m}^{2}$

Ilustração 25 - Nascente do Sapé: Detalhe da Seção do córrego antes e depois da canalização. Fonte: Elaborado pela autora. 
A llustração 26 mostra imagens da Nascente do Sapé na estaca 31, obtidas em 13/08/2008, onde por tratar-se de um período marcado pela baixa precipitação, pode-se notar pouco depósito de resíduos sólidos trazidos pelo escoamento superficial na nascente (Foto A), no entanto, a água do corpo apresentava cor e turbidez características de corpos d'água com alta concentração de matéria orgânica em decomposição, evidenciando a presença de efluentes sanitários (Foto B). Já as fotos C, D e E obtidas no mesmo ponto em 08/02/2012, nota-se, por se tratar de uma imagem obtida no período chuvoso, um considerável acúmulo de resíduos sólidos na nascente. Apesar das intervenções do programa já estarem concluídas neste segundo momento, o corpo d'água não apresenta visualmente um aspecto saudável e sua causa pode ser atribuída principalmente à ocorrência de lançamentos clandestinos ainda não identificados, provavelmente de origem industrial.

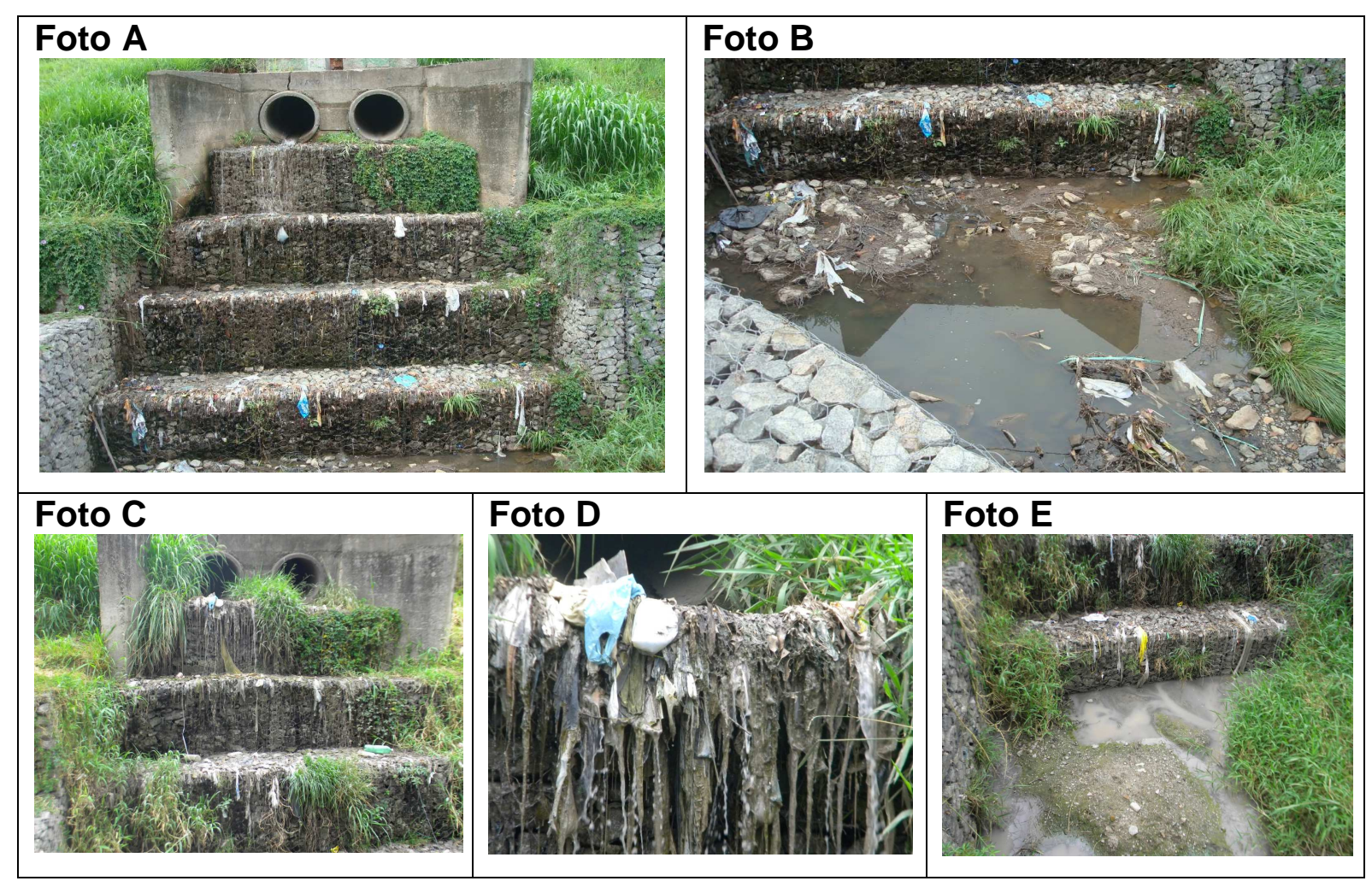

Ilustração 26 - Nascente do Sapé: Fotos A e B: Detalhe da desembocadura da travessia da Rodovia Raposo Tavares e detalhe da característica visual das águas da nascente em 13/08/2008. Fonte: Cortesia de Andréia Sandrini - Coordenadora das ações do programa "Córrego Limpo" na Zona Oeste. Fotos C, D e E: Detalhe da desembocadura da travessia da Rodovia Raposo Tavares e detalhe da característica visual das águas da nascente em 08/02/2012. Fonte: Fotos da autora. 
A llustração 27 mostra duas fotos do ponto situado na Estaca $29 \mathrm{em}$ instantes diferentes. A primeira (Foto A) foi obtida em visita ao canal, em 08/02/2012, onde não havia ocorrência de chuva nos últimos dias e havia agentes da prefeitura realizando a limpeza do canal, e a segunda (Foto B), foi obtida em 14/03/2012 horas depois de um evento de chuva. Pode se notar claramente a grande quantidade de resíduos sólidos no canal, trazidos pelo escoamento superficial, além da carga difusa poluidora que fica oculta pelo material grosseiro, como óleos, graxas, metais, etc., mostrando o quão óbvia é a influência da carga difusa em bacias urbanas.

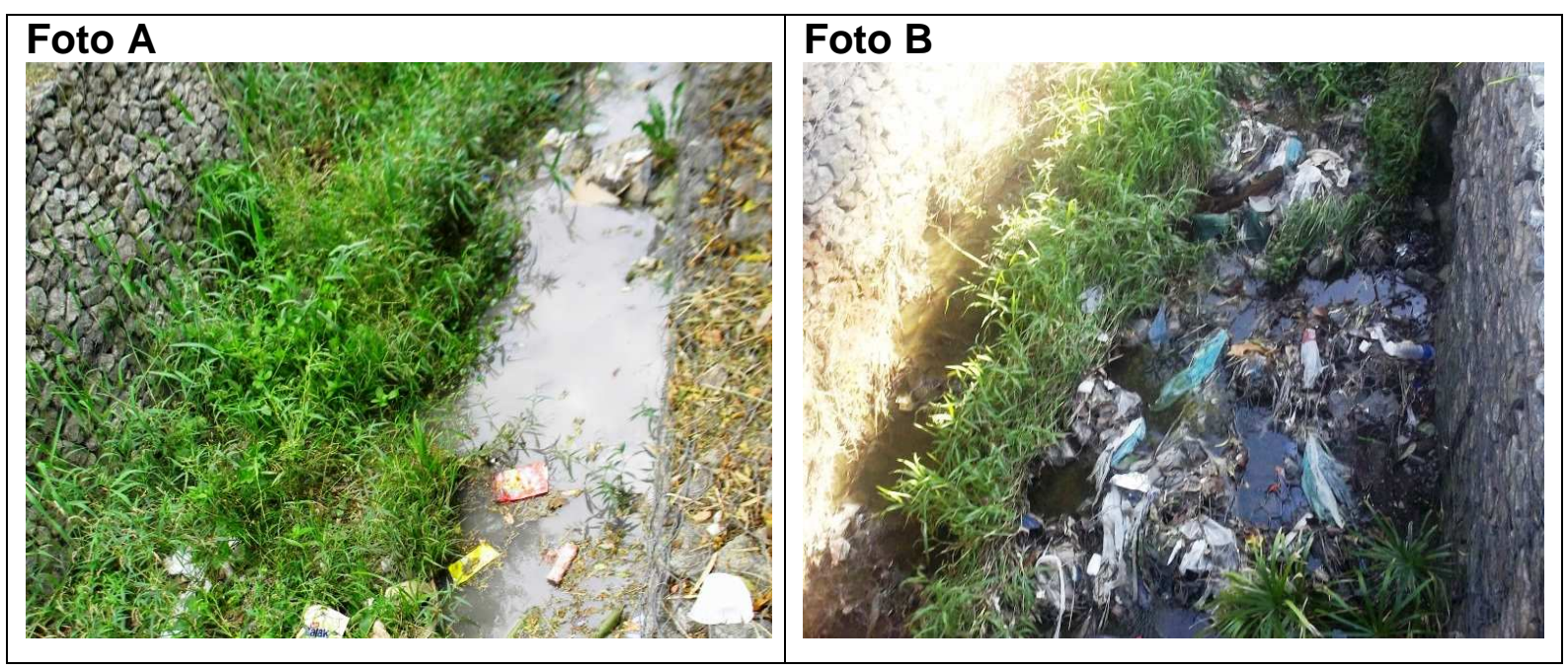

llustração 27 - Nascente do Sapé: Acumulo de resíduos sólidos no Canal antes (Foto $A$ ) e depois (Foto B) de um evento de chuva. Fonte: Fotos da autora.

A llustração 28 apresenta fotos obtidas em 08/02/2012, neste ponto do canal (Estaca 28 a 30), podemos observar o acumulo de resíduos sólidos trazidos pelo escoamento superficial nas canaletas marginais (Foto A) e uma visão geral do primeiro trecho aberto do canal (Foto B). A Foto $\mathrm{C}$ apresenta um detalhe do fundo do canal em gabião; a prefeitura relata dificuldades em trabalhar na limpeza de canalizações com este material, uma vez que o gabião retém os resíduos sólidos no fundo do canal e impossibilita o uso de algumas ferramentas utilizadas pelos operadores para limpeza. Na região há diversas nascentes que convergem para o trecho inicial do canal, é possível visualizar o lançamento de algumas delas no canal através de galerias de águas pluviais (GAP's) com água limpa corrente, mesmo na ausência de chuvas, como mostrado na Foto $D$. Além desses casos de deságue em GAP's, há outras nascentes na bacia que são usadas pela comunidade local para lavagem de automóveis e recreação, tornando-se pontos críticos por poderem ser 
possíveis focos de doenças de veiculação hídrica se não tomados os cuidados necessários pela população.

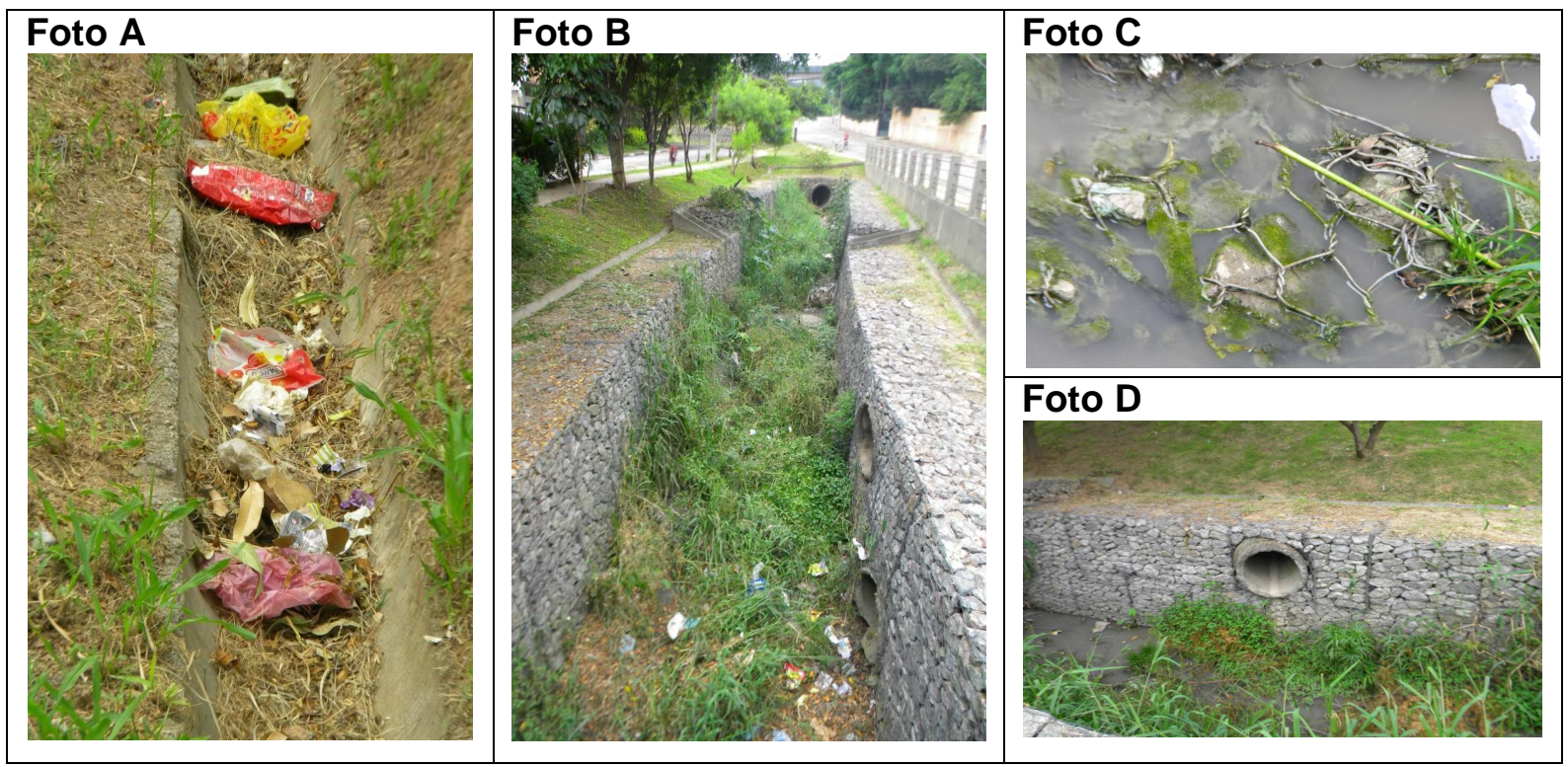

Ilustração 28 - Nascente do Sapé: Foto A: Detalhe da canaleta marginal ao canal. Foto B: Visão geral do canal. Foto C: Detalhe do Fundo do Canal em gabião. Fotos D: Detalhes dos lançamentos no canal de nascentes da região através de galerias de águas pluviais (GAP's). Fonte: Fotos da autora.

Com as ações de intervenção na bacia concluídas há a manutenção da limpeza do canal, que inclui a retirada de resíduos sólidos e poda da vegetação. Em visita ao canal em 06/06/2013 observou-se que o canal está novamente sobre forte influência de cargas pontuais, influência constatada pela coloração da água apresentada no instante. Novas ligações de esgoto clandestinas estão sendo efetuadas e se o processo se mantiver, rapidamente o canal voltará ao estagio de comprometimento anterior às intervenções. Fica claro o quão complexo é o processo de despoluição em bacias com alto potencial poluidor, como é o caso da Nascente do Sapé, ressaltando a importância das ações contínuas na bacia, pois não há como consolidar o processo sem acompanhamento constante. Além disso, é notória a importância da gestão participativa, pois a formação de gestores que atuem na bacia divide a responsabilidade e integra os usuários ao problema, tornando o processo de consolidação sustentável. As ações do programa são de extrema importância, mas sem o envolvimento da população residente no processo se torna insustentável e resulta no desperdício de boa parte dos recursos investidos. A sequência de Fotos da llustração 29, obtidas em 06/06/2013, mostram a situação atual do canal. 


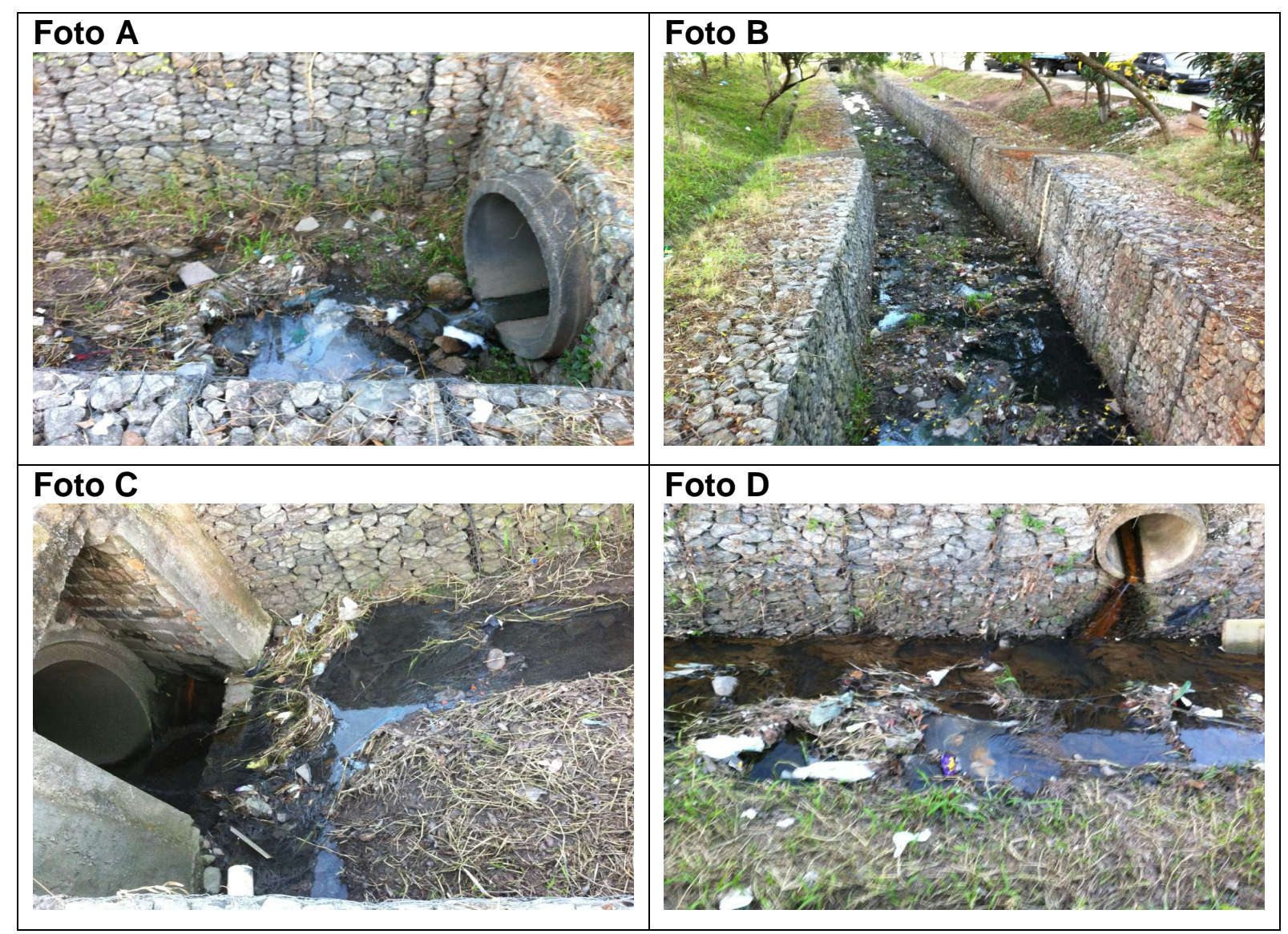

llustração 29 - Nascente do Sapé: Foto A, B, C e D: Condição do canal em 06/06/2013 nas estacas 30, 27 e 28 e 26 respectivamente. Fonte: Fotos da autora.

\subsubsection{Parque linear 28}

Com a criação da lei 13.430 em 2002, que instituiu Plano Diretor Estratégico do Município de São Paulo, houve a criação da proposta de parques lineares, como uma forma de recuperação ambiental de cursos d'água e aumentar a área permeável nas áreas urbanas. Com isso foi criado o Parque linear 28, no Córrego do Sapé (AKINAGA et al., 2007). A implantação do parque linear 28 no Córrego do Sapé foi dividida em duas etapas, cuja primeira (Trecho 1 do Córrego do Sapé, que contempla a Nascente), foi concluída ao final de 2009 e a conclusão da segunda (Trecho 2 do Córrego do Sapé, que contempla a área da Favela do Sapé) esta prevista inicialmente para meados de 2012, mas que devido a atrasos no cronograma inicial até hoje não encontra-se concluída. Portanto a urbanização da Favela e a despoluição dos dois trechos pelo programa resultarão na implantação completa do Parque Linear, no entanto, no que se refere à despoluição dos dois trechos, como já ressaltado, o processo é complexo e à medida que não são 
observadas algumas etapas importantes, como a conscientização da população, o processo se torna insustentável. Os itens seguintes detalham o processo de implantação dos dois trechos do parque linear e os principais aspectos e desafios envolvidos nas suas respectivas implantações.

\subsubsection{Parque linear 28: Trecho 1}

As obras do Trecho 1 do Parque linear 28, implantado no Córrego do Sapé na área de sua Nascente, tiveram inicio em 2007 e foram concluídas em 2009, o projeto deste trecho contemplou a execução da canalização deste trecho do canal, implantação de vegetação em suas margens, além de áreas de lazer com quadras, rampas de skate e equipamentos de ginástica. A sequência de fotos apresentadas na llustração 30 mostram imagens das obras executadas neste trecho, obtidas em 08/08/2012. A Foto A mostra uma vista da execução do sistema de drenagem e as Fotos $B, C$ e D mostram diferentes vistas da construção das áreas de lazer.
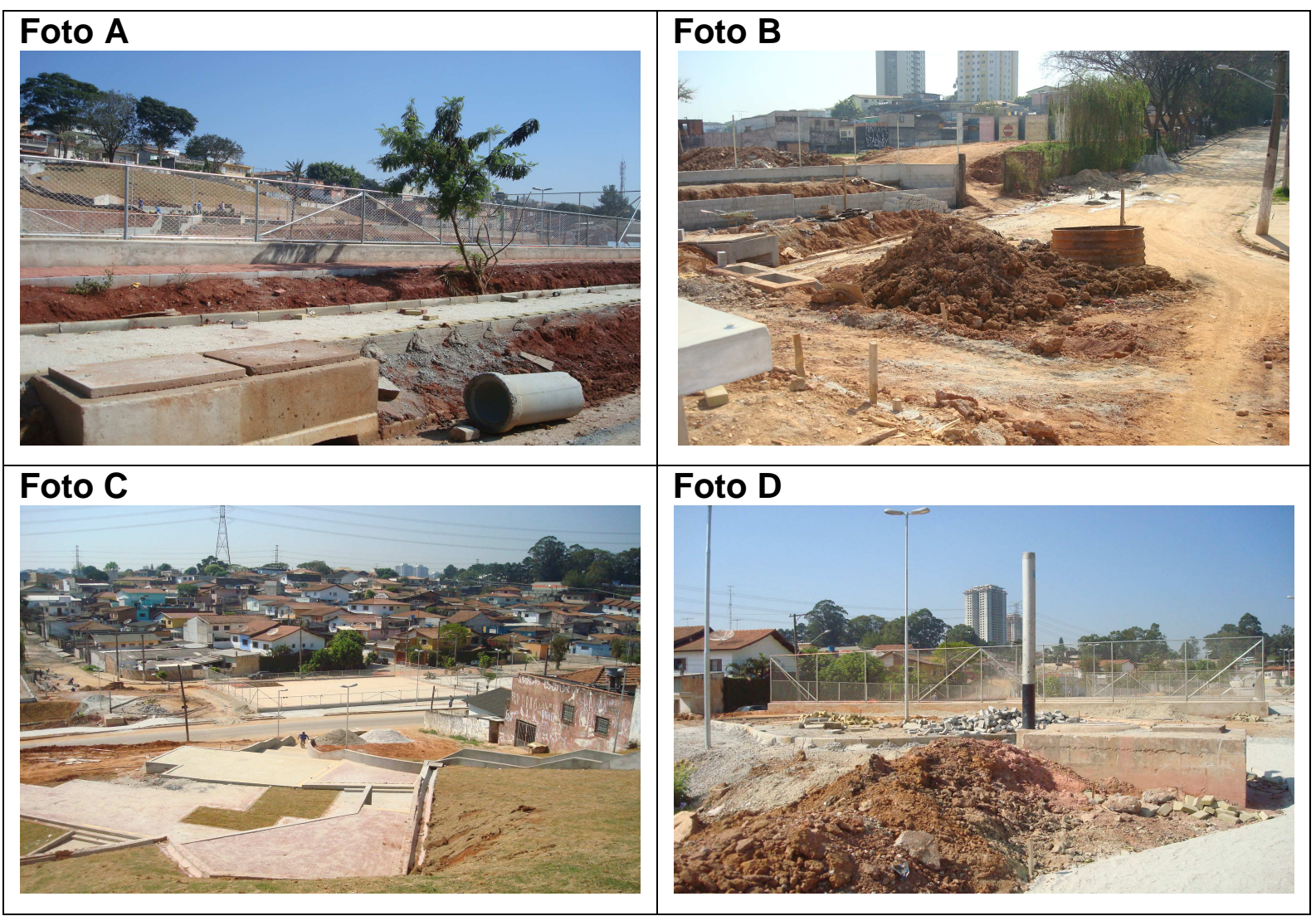

llustração 30 - Parque Linear 28 - Trecho 1: Sequência de fotos mostrando as obras do sistema de drenagem da bacia (Foto $A$ ) e as obras de implantação das áreas de lazer (Foto B, C e D). Fonte: Cortesia de Andréia Sandrini - Coordenadora das ações do programa "Córrego Limpo" na Zona Oeste. 
Atualmente este trecho do parque linear, devido às estruturas de lazer presentes, é amplamente utilizado pela população local, ficando clara a importância desses elementos para integração do corpo d'água à paisagem urbana e à população. A sequência de Fotos apresentadas na llustração 31 , obtidas em 06/06/2013, mostra o trecho 1 do Parque Linear 28 atualmente, mostrando na Foto $A$ e $B$ as estruturas de lazer, na Foto $C$ a área verde nas margens do canal e na Foto $\mathrm{D}$ a canalização concluída.

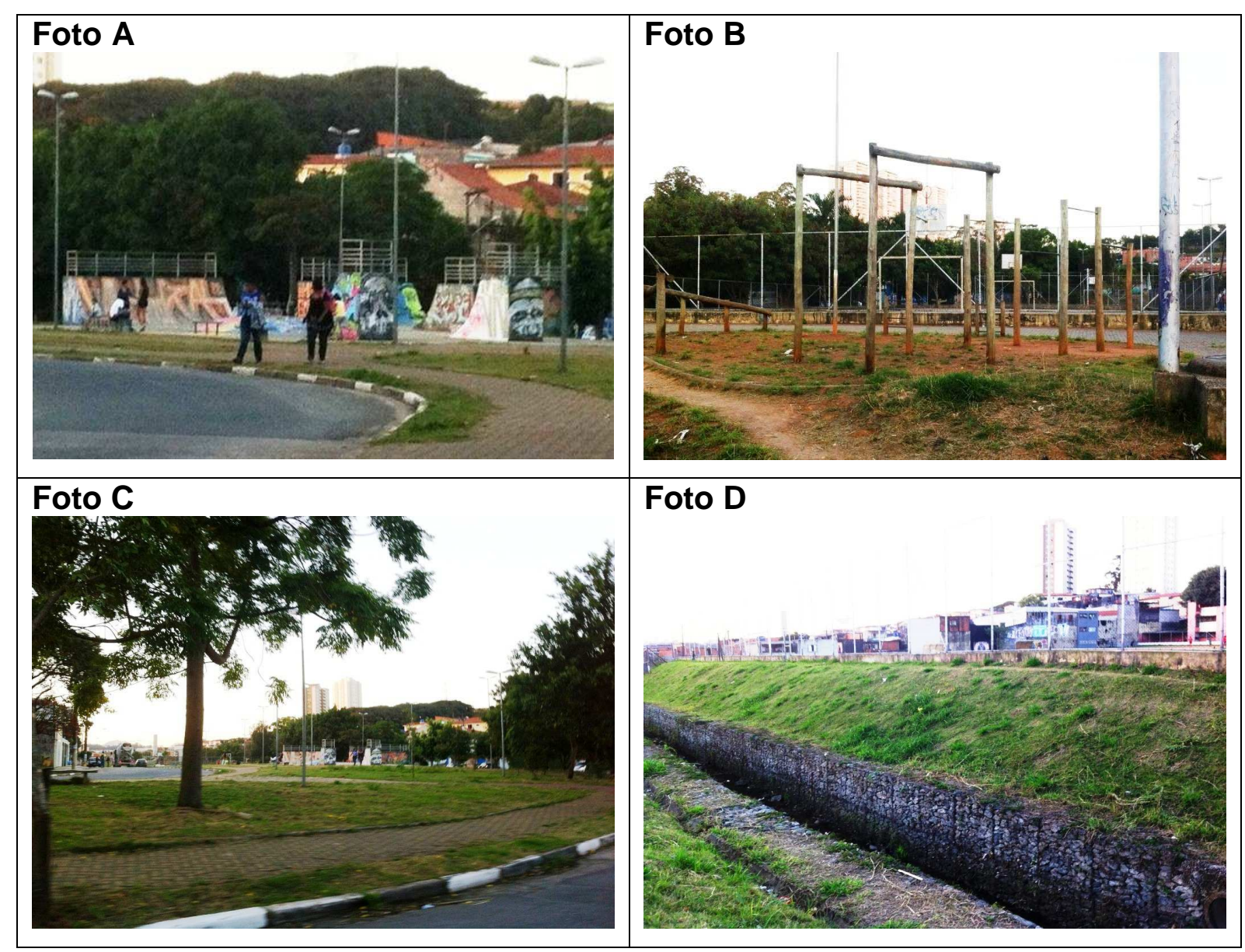

llustração 31 - Parque Linear 28 - Trecho 1: Sequência de fotos, obtidas em 06/06/2013, mostrando o parque linear atualmente. Fonte: Fotos da autora.

\subsubsection{Parque linear 28: Trecho 2}

As obras do Trecho 2 do Parque linear 28, implantado no Córrego do Sapé na área da Favela do Sapé, tiveram inicio em 2009 e a nova previsão de conclusão é ao final de 2013, o projeto deste trecho contempla a execução de obras para a canalização do córrego, implantação de áreas de lazer e de conjuntos habitacionais. A llustração 32 a seguir mostra a concepção prevista para o parque linear no trecho. 


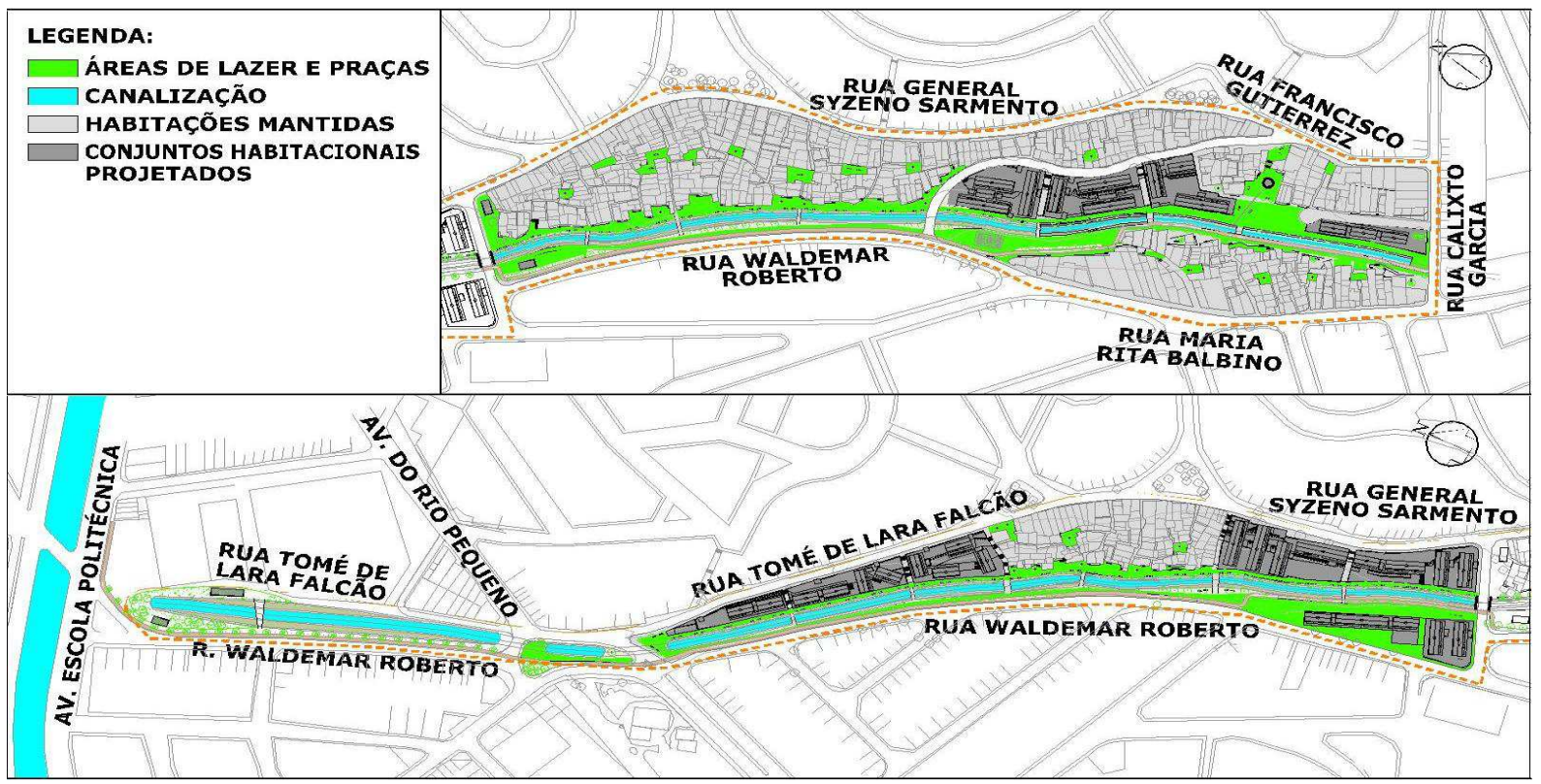

llustração 32 - Parque Linear 28 - Trecho 2: Concepção do parque linear. Fonte: Elaborado pela autora.

Para tanto foram necessárias diversas medidas para a remoção da população residente às margens do canal, trabalho este realizado por agentes sociais destinados pela Secretaria da Habitação do município de São Paulo (SEHAB), que através do fornecimento de auxílios aluguel conduzem o processo de remoção da população residente nas áreas consideradas críticas e de interesse para implantação das novas unidades habitacionais. Após a conclusão das intervenções na área essa população é realocada nos novos conjuntos habitacionais. Tal ação dos agentes sociais muitas vezes encontra alguns entraves, já que depende do consentimento da população residente. Portanto esta fase do processo pode demandar tempo e muitas vezes é responsável por atrasos no andamento de tais iniciativas. O processo de criação de parques lineares muitas vezes tende a esbarrar em questões como esta, uma vez que a maioria dos corpos d'água em áreas densamente urbanizada como São Paulo e que ainda não estão tamponados, abrigam favelas em suas margens, portanto a urbanização destas favelas torna-se nestes casos parte do processo. Portanto podemos considerar as seguintes etapas anteriores às obras civis, que fazem parte do processo de implantação de parques lineares em áreas urbanas tipicamente adensadas: 1 Etapa: Estudos populacionais e a identificação de áreas críticas; $2^{2}$ Etapa: Ação de agentes sociais junto à 
população, para auxilio no processo de remanejamento destas; e $3^{\text {a }}$ Etapa: Demolição e limpeza da área.

A llustração 33 mostra a sequência dos primeiros eventos do processo de urbanização da favela do sapé para criação do parque linear. As Fotos A e B foram obtidas em 27/04/2010, antes do inicio das obras de intervenção no segundo trecho, onde podemos notar a situação do córrego no trecho referente às estacas 15 a 16 . As Fotos C e D foram obtidas em 20/06/2011, durante o processo de demolição das moradias em áreas de risco ou em áreas de interesse para implantação dos conjuntos habitacionais e áreas de lazer, no trecho próximo às estacas 8 a 10 .

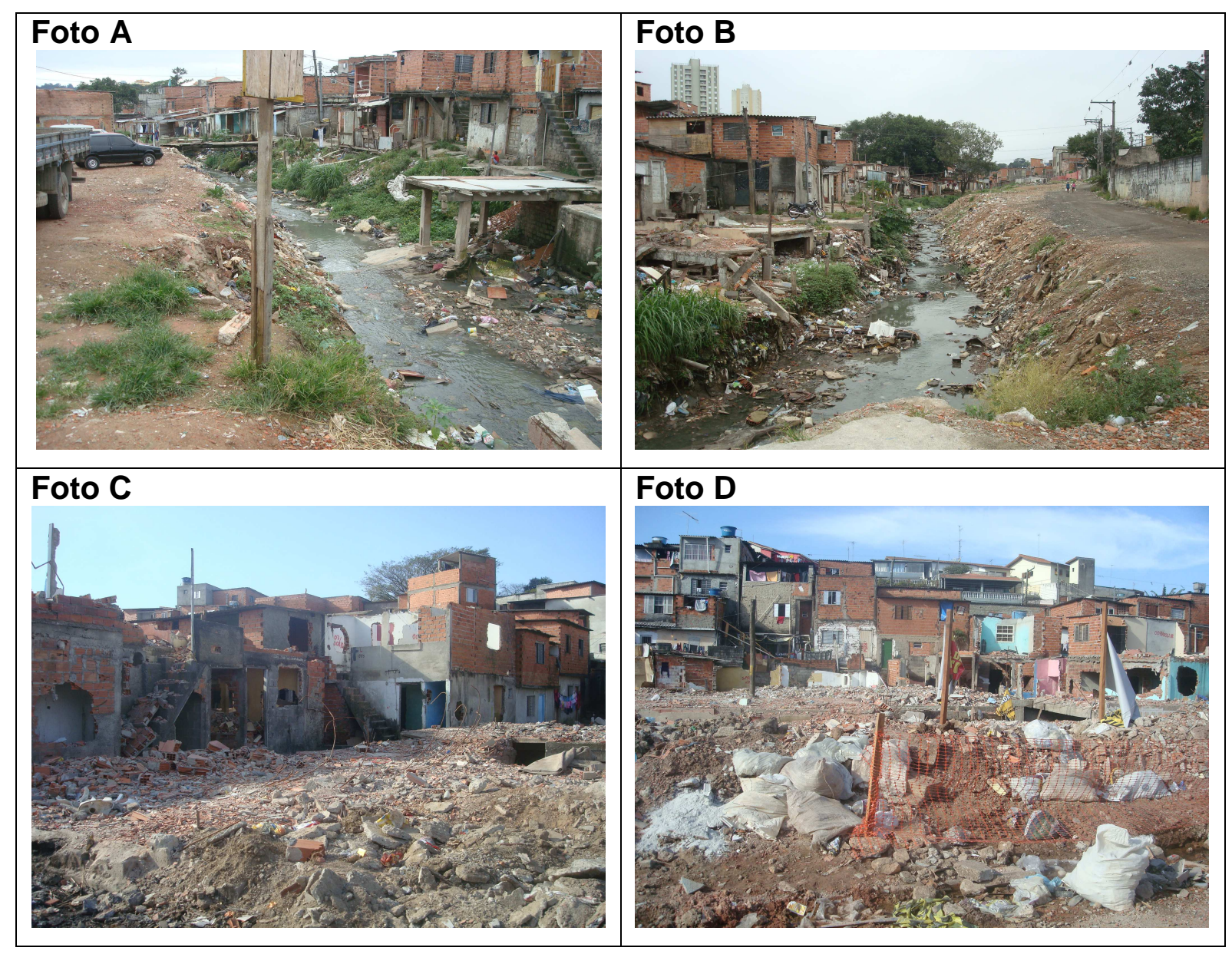

Ilustração 33 - Parque Linear 28 - Trecho 2: Sequência de fotos mostrando o canal antes das obras de intervenção (Fotos $A$ e B) e a evolução das primeiras intervenções para implantação do parque (Fotos $C$ e D). Fonte: Cortesia de Andréia Sandrini - Coordenadora das ações do programa "Córrego Limpo" na Zona Oeste.

A llustração 34 mostra fotos obtidas em 27/10/2011 (Foto A), em 01/12/2011 (Foto B) e em 04/01/2013 (Foto C), nas estacas 15, 16 e 5 respectivamente, durante 
a execução das obras de canalização do córrego. llustrando, portanto a evolução das obras de canalização do córrego.

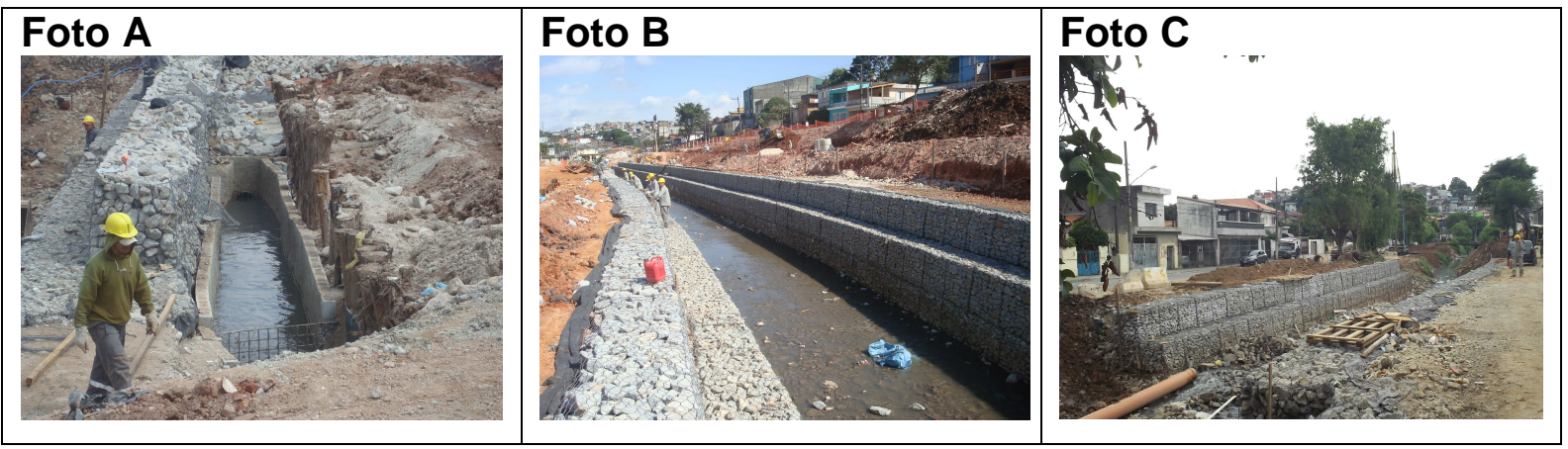

Ilustração 34 - Parque Linear 28 - Trecho 2: Evolução das obras de canalização do córrego - Fotos A e B, obtidas em 27/10/2011 e 01/12/2011 respectivamente - Fonte: Cortesia de Andréia Sandrini - Coordenadora das ações do programa "Córrego Limpo" na Zona Oeste; e Foto C obtida em 04/01/2013 - Fonte: Foto da autora.

A llustração 35 mostra fotos obtidas em 06/06/2013 nas estacas 11 e 5 respectivamente, mostrando a conclusão das obras referentes à canalização. A canalização foi realizada com a utilização de gabião caixa para a estabilização das margens e com a utilização de laje em concreto armado coberta com enrocamento natural para tratamento do fundo. No item 3.3 são descritos em detalhe os aspectos particulares das técnicas de tratamento das margens e fundo de canalizações.

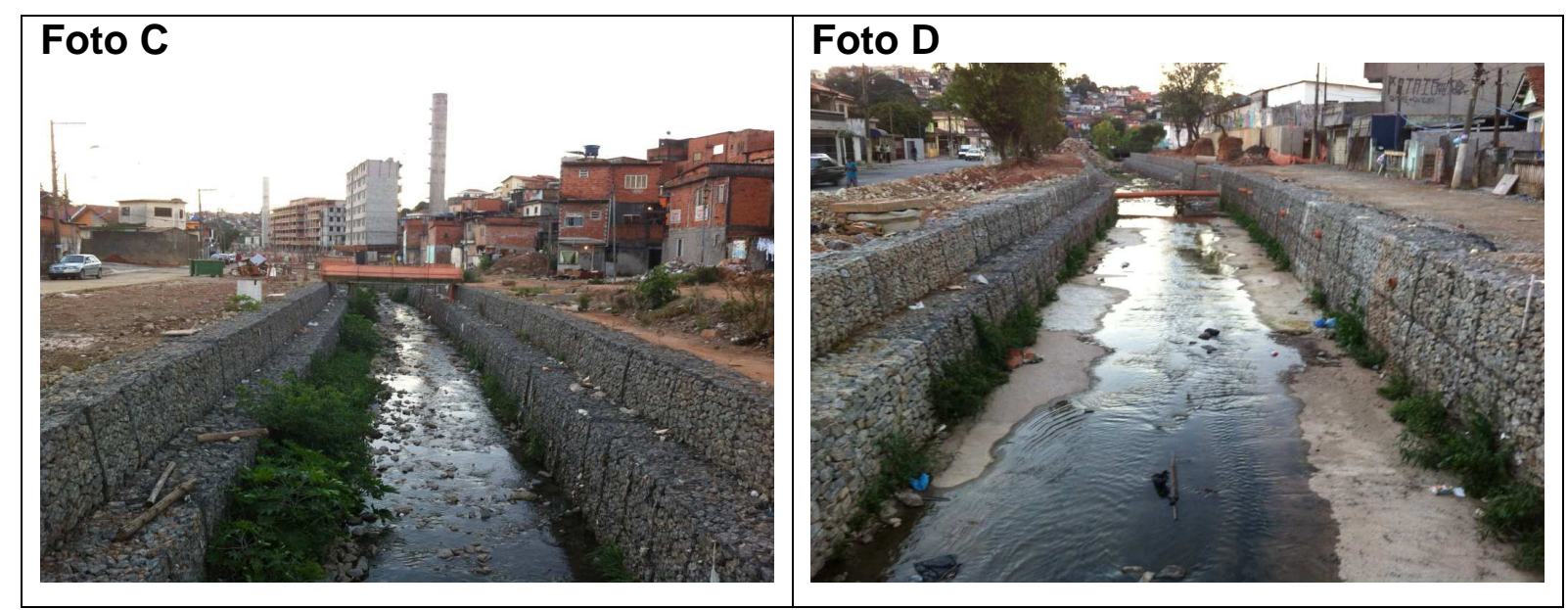

llustração 35 - Parque Linear 28 - Trecho 2: Conclusão das obras de canalização do córrego (Fotos A e B). Fonte: Fotos da autora.

A Ilustração 36 mostra fotos obtidas em 04/01/2013 (Foto A) e em 06/06/2013 (Foto B) na estaca 8 e obtida em 06/06/2013 na estaca 20, ilustrando a evolução da construção dos conjuntos habitacionais. 


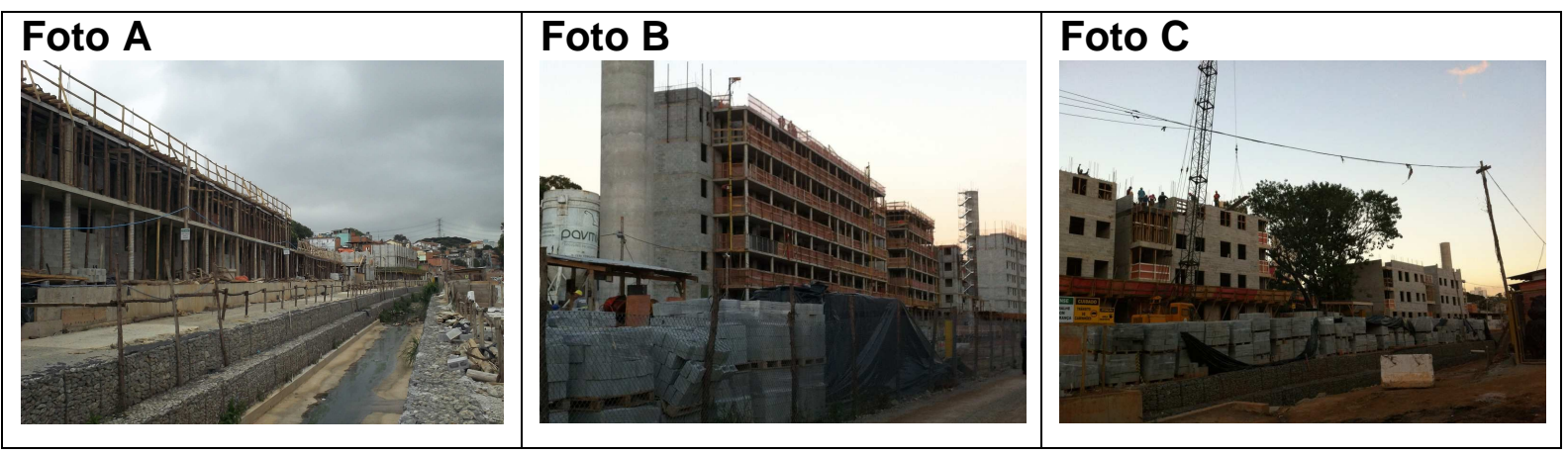

llustração 36 - Parque Linear 28 - Trecho 2: Evolução das obras para implantação dos conjuntos habitacionais - Foto A e B obtidas em 04/01/2013 e 06/06/2013 respectivamente na estaca 8 e Foto $C$ obtida em 06/06/2013 na estaca 20. Fonte: Fotos da autora.

O estudo do processo de implantação do parque linear deixa clara a importância de tais obras na integração do corpo d'água à paisagem urbana, uma vez que o resultado imediato desta implantação é a redução da ocorrência de enchentes, o corpo d'água passa a ser visto pela população de maneira distinta e a medida que a população passa a conviver com o corpo d'água através da utilização das áreas de lazer implantadas em suas margens, esta passa a se preocupar com a preservação deste. Antes da implantação do parque, o córrego do Sapé representava para a população do local, não um elemento natural, mas sim um elemento urbano que era um manancial de problemas, devido às constantes enchentes, aos esgotos e resíduos diversos nele presentes. No entanto, ao sanar tais problemas surge uma nova percepção sobre o corpo d'água que deve ser trabalhada para que a população relacione os impactos de suas ações sobre o corpo d'água. Portanto, vale salientar que é de extrema importância que a conclusão das obras civis venha acompanhada de um intenso trabalho de conscientização ambiental junto à população para auxilio na manutenção do parque linear, umas vez que diferente de populações ribeirinhas tradicionais, que tem uma forte relação com o corpo d'água e consciência da importância da manutenção da sua qualidade ambiental, já que este é provedor dos elementos para sua sobrevivência, populações "ribeirinhas" de córregos urbanos não possuem esta relação, pois muitas vezes sua relação temporal com o corpo d'água é curta, não dependem dele para seu sustento e por todas as mazelas trazidas por este em momentos passados. 


\subsection{CÓRREGO IBIRAPORÃ}

\subsubsection{Caracterização da área}

O Córrego Ibiraporã pertencente à bacia do Pirajussara, localizado na subprefeitura do Butantã, tem como principais pontos de acesso as Avenidas Eliseu de Almeida e Francisco Morato, a bacia de drenagem do córrego conta com uma população tipicamente residencial, com cerca de 9 mil habitantes (CÓRREGO LIMPO, s/d). A llustração 37 mostra a bacia de contribuição do Córrego Ibiraporã; além disso, é possível visualizar o ponto de amostragem para análise da $\mathrm{DBO}_{5,20}$ realizada pela SABESP e o estaqueamento para localização do memorial fotográfico.

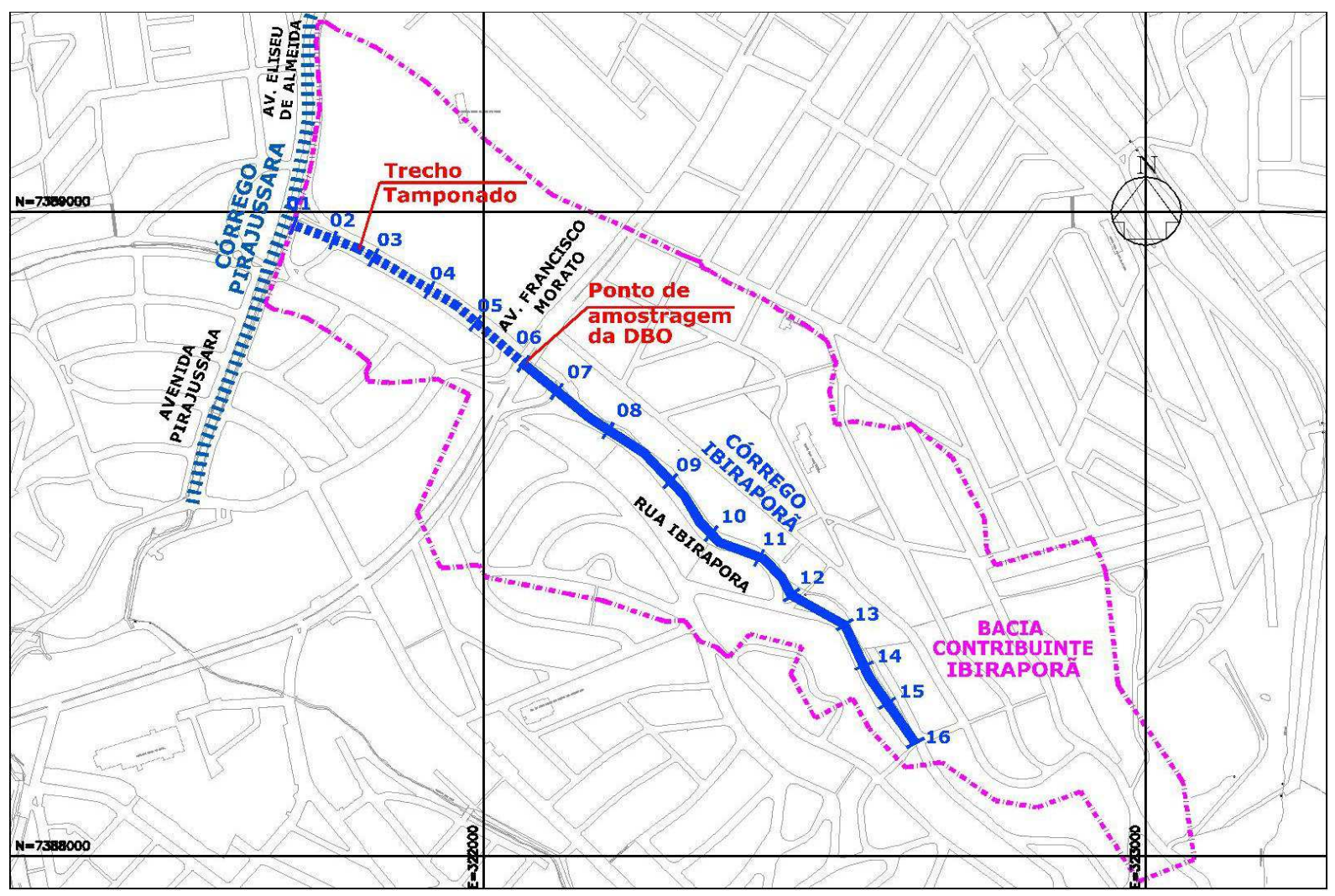

Ilustração 37 - Córrego Ibiraporã: Bacias Contribuintes. Fonte: Elaborado pela autora.

\subsubsection{Programa de governança colaborativa}

O Córrego lbiraporã é um dos córregos que fazem parte do programa de governança colaborativa, que através do envolvimento da população residente na 
bacia no processo de recuperação do córrego, tem apresentado resultados mais efetivos na sua despoluição (CÓRREGO LIMPO, s/d).

A participação da comunidade torna mais efetivo o processo de despoluição, pois integra a população no processo. Na bacia do Córrego Ibiraporã, graças ao programa de governança colaborativa, a população residente auxilia o programa gerindo melhor seus resíduos e também na fiscalização de eventuais anomalias no canal ocasionadas por lançamentos clandestinos ou despejo de resíduos sólidos nas proximidades do canal que porventura possam ser carreados pelo escoamento superficial, resultando na alteração imediata do aspecto visual das águas do córrego, indicativo de degradação da qualidade de suas águas. O programa cria um via de comunicação direta com a população da bacia, o que facilita as ações do programa e encoraja a participação da população.

Como parte das ações do programa de governança colaborativa, a SABESP em parceria com a Fundação SOS Mata Atlântica e o Centro Brasileiro de Análise e Planejamento - CEBRAP - em conjunto com as lideranças locais, realizou em 26/03/2012 uma "Ecomobilização" no Córrego Ibiraporã para envolver a comunidade no processo de manutenção da despoluição do córrego. Na "Ecomobilização" houve discussões sobre o papel da comunidade na despoluição do córrego, palestra sobre a preservação e educação ambiental, além de caminhada e mutirão de limpeza (CÓRREGO LIMPO, s/d).

\subsubsection{Processo de recuperação}

A Ilustração 38 mostra fotos obtidas próximo à Estaca 8, em instantes diferentes. A primeira foto (Foto A) foi obtida em 12/02/2009 no inicio das ações do programa no córrego, onde é possível observar que o córrego apresentava cor e turbidez características de corpos d'água com alta concentração de matéria orgânica em decomposição, evidenciando a presença de efluentes sanitários. Já na segunda foto (Foto B), obtida em 17/02/2011, após a conclusão das ações do programa, onde já é visível certa melhoria visual na qualidade da água do corpo d’água. 


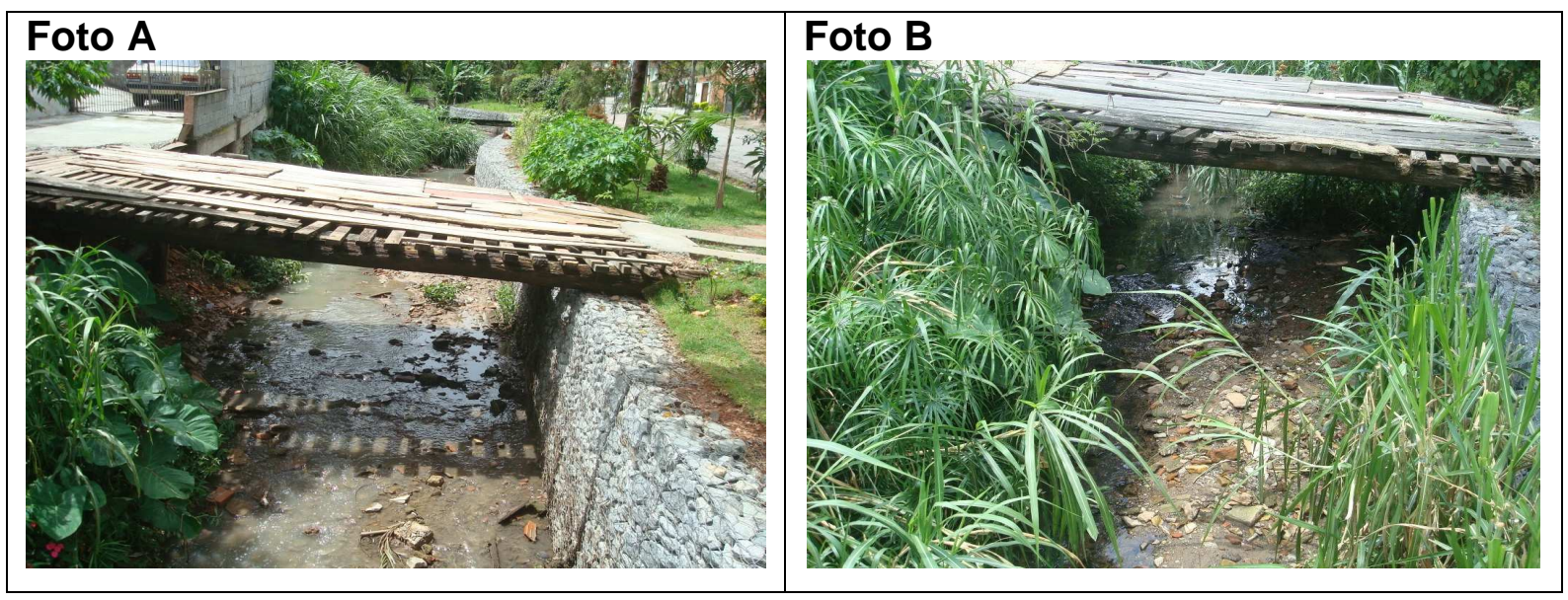

llustração 38 - Córrego lbiraporã: Estaca 8 - Antes (Foto A) e depois (Foto B) das intervenções do programa. Fonte: Cortesia de Andréia Sandrini - Coordenadora das ações do programa "Córrego Limpo" na Zona Oeste.

A llustração 39 mostra fotos obtidas próximo à Estaca 13 e 9 respectivamente, mas em instantes diferentes. A Foto A foi obtida em 02/04/2008 e a Foto $B$ em 17/02/2011. Antes e depois das intervenções do programa.

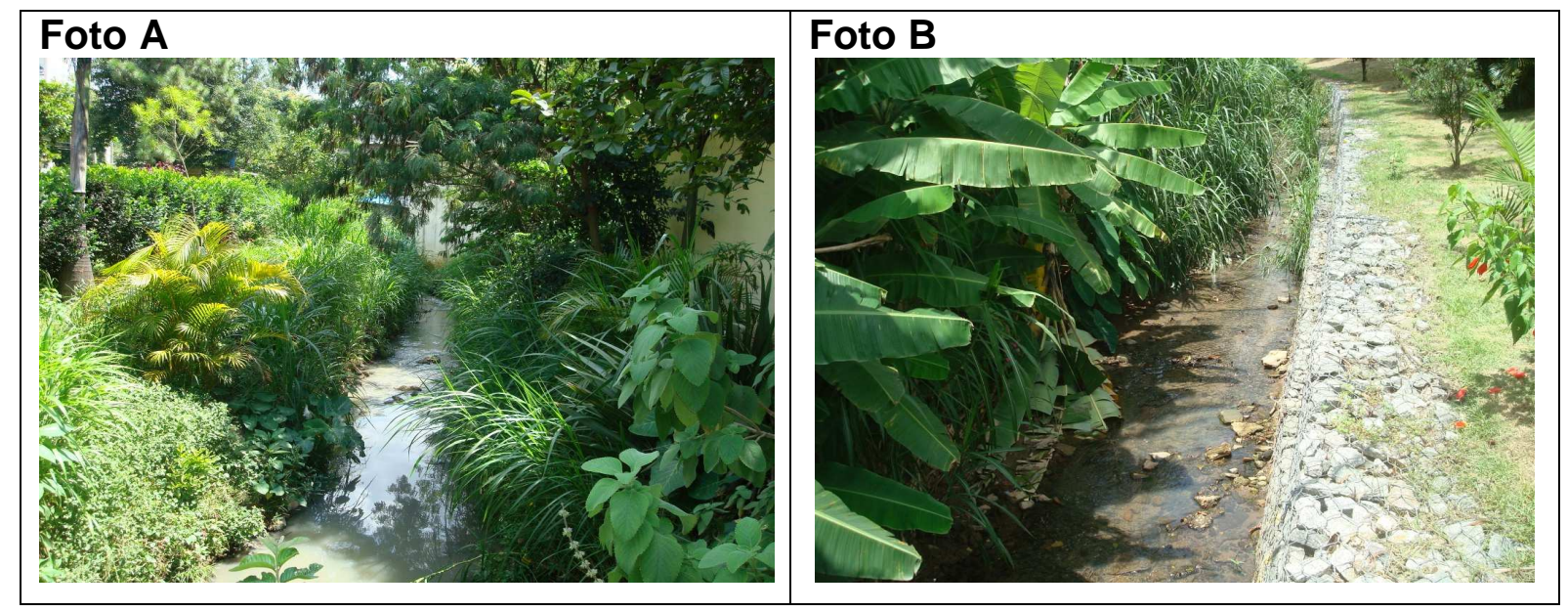

Ilustração 39 - Córrego Ibiraporã: Estaca 13 - Antes (Foto A) e Estaca 9 - depois (Foto B) das intervenções do programa. Fonte: Cortesia de Andréia Sandrini Coordenadora das ações do programa "Córrego Limpo" na Zona Oeste.

Um dos grandes desafios encontrados em sistemas de esgotamento sanitário é o esgotamento de fundos de vale, pois o escoamento utilizado em redes de esgotos públicas no Brasil se dá principalmente em condutos livres, ou seja, condutos que dependem da gravidade para escoar os fluidos transportados, portanto todo o esgotamento de uma bacia tende naturalmente a ser direcionado para o canal de drenagem da bacia. Habitações localizadas próximas ao canal, por tratar-se de 
soleiras negativas (Residências que tem sua instalação predial de esgotos orientada naturalmente para o fundo do lote), são de difícil esgotamento, pois demandam a implantação de coletores de fundo de vale que nem sempre são de fácil execução, e a ausência destes coletores muitas vezes resulta no lançamento dos esgotos das residências nesta situação diretamente no canal. Uma das ações do programa no Córrego Ibiraporã contemplou a execução de uma rede coletora às margens do canal, cuja travessia sobre este pode ser observada na Foto A da llustração 40 a seguir. Apesar da implantação desta rede, novas ligações clandestinas têm sido criadas no canal, como podemos ver nas Fotos B e C da mesma ilustração, representando um grande desafio no processo de consolidação da despoluição do córrego. Graças às denuncias da população local mais atuante, estas ligações são constantemente desativas pela SABESP, no entanto, mesmo que ativas por um pequeno período estas ligações comprometem e retardam a restauração da qualidade ambiental do corpo d'água. As fotos da llustração 40 foram obtidas em 09/10/2012.

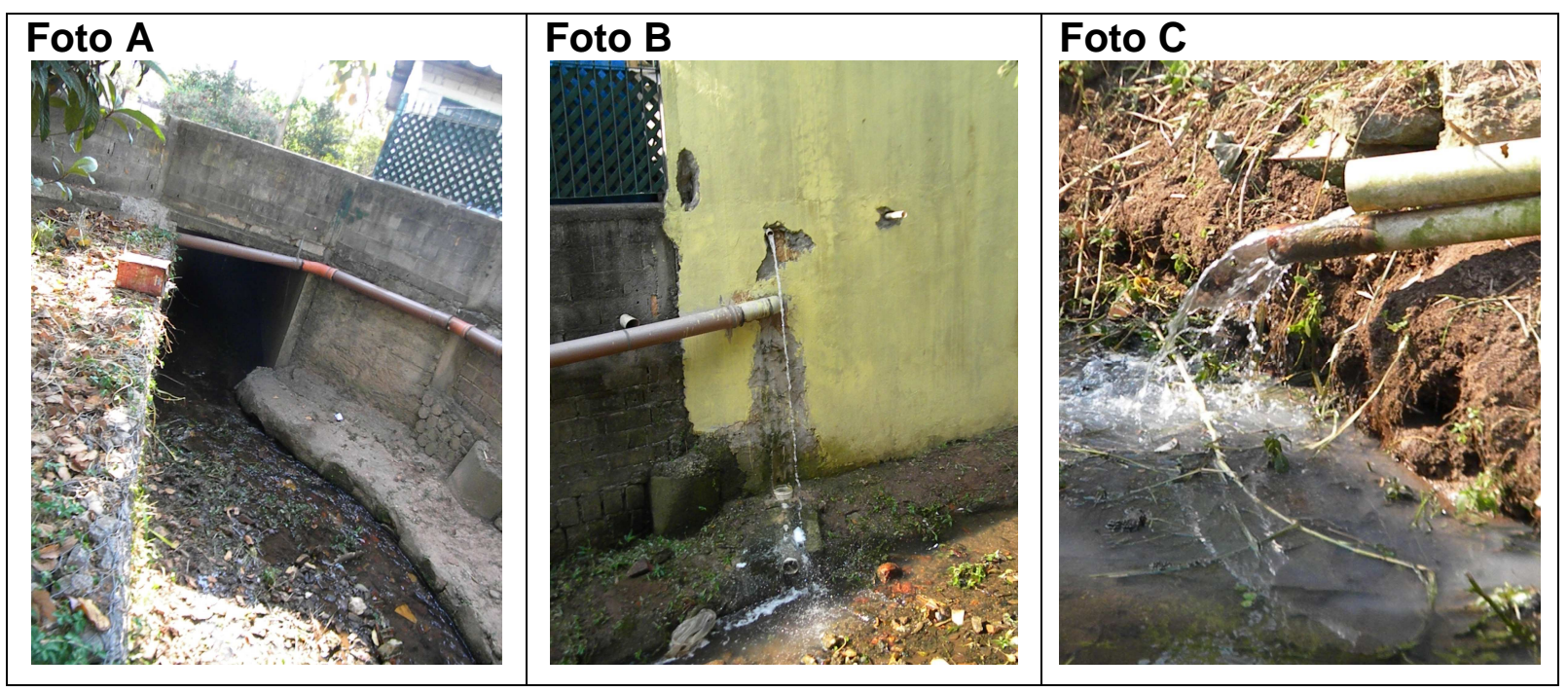

llustração 40 - Córrego Ibiraporã: Estaca 7 - Travessia da rede de esgotos pública sobre o canal (Foto A) e Estaca 6 - Lançamento irregular de esgotos (Foto B e C). Fonte: Fotos da autora.

A llustração 41 mostra imagens de alguns trechos do canal, ilustrando a heterogeneidade do canal com relação ao tratamento de suas margens, fundo e a vegetação presente. A Foto A mostra o trecho inicial do córrego, na Estaca 16, onde pode se observar chegadas de GAP's (Galerias de Águas Pluviais) e de outras galerias que conduzem águas de diversas nascentes da bacia a este trecho inicial. A 
Foto B mostra o trecho do canal entre as Estacas 12 a 13, onde tratar se de um trecho mais arborizado e às margens do canal podemos ver uma abundante vegetação. Além disso, neste trecho o canal não apresenta gabião em suas margens e fundo, o que propicia este aspecto mais natural. A Foto $\mathrm{C}$ mostra o canal entre as Estacas 12 a 11, onde temos as margens do canal mais expostas à luz e como resultado disto o predomínio de gramíneas. A Foto $D$ mostra o canal entre as Estacas 10 a 8, neste trecho podemos ver as margens do canal protegidas por gabião. Além disto, a llustração traz Fotos de E a G, obtidas em 09/10/2012, que mostram o fundo do canal que apresenta trechos com o fundo em cascalho e areia (Fotos $\mathrm{E}$ e $\mathrm{F}$ ) e trechos com gabião (Foto $\mathrm{G}$ ) onde é notável o acumulo de resíduos que ficam presos à tela.
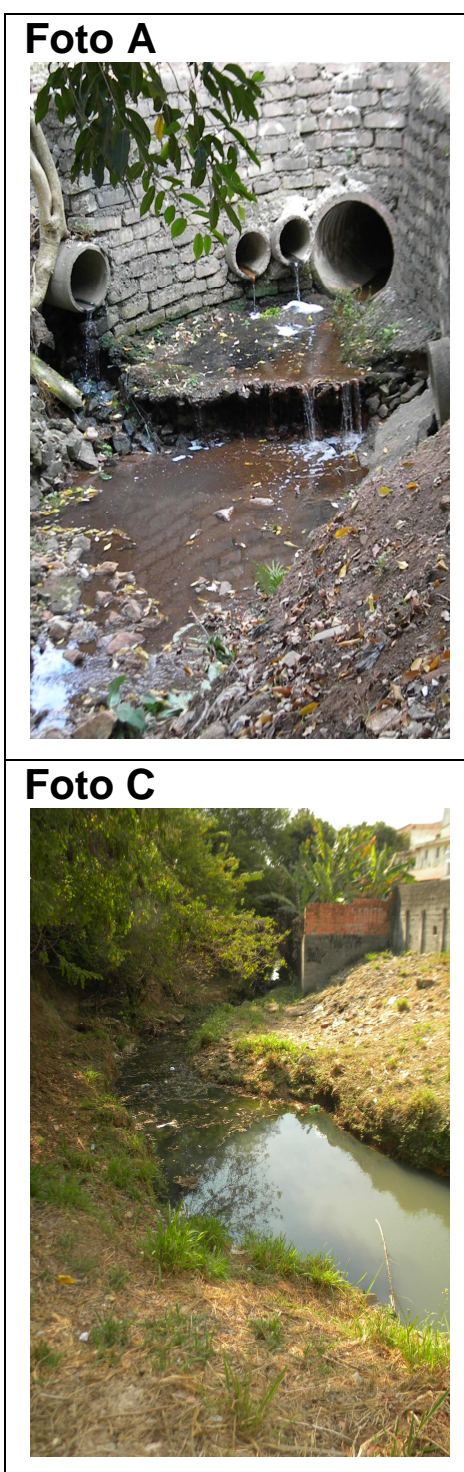

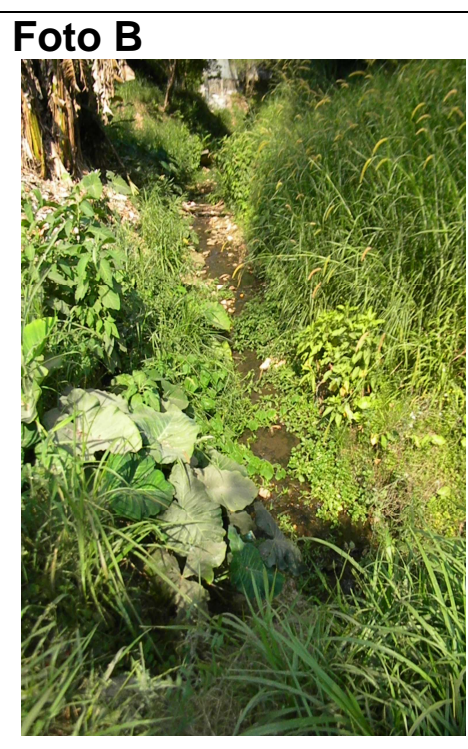

\section{Foto D}

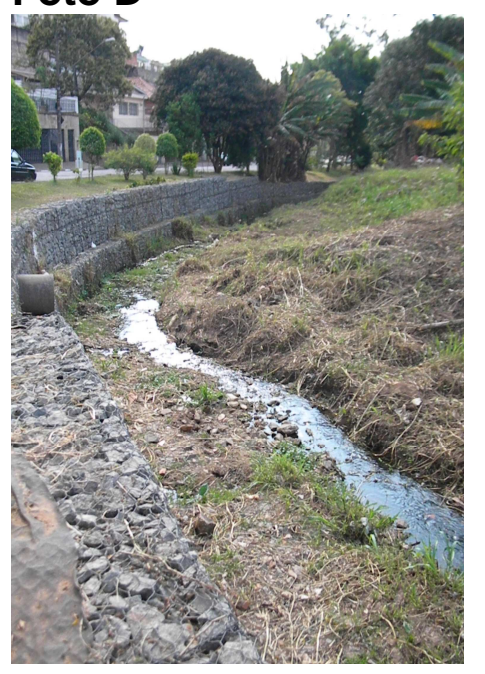

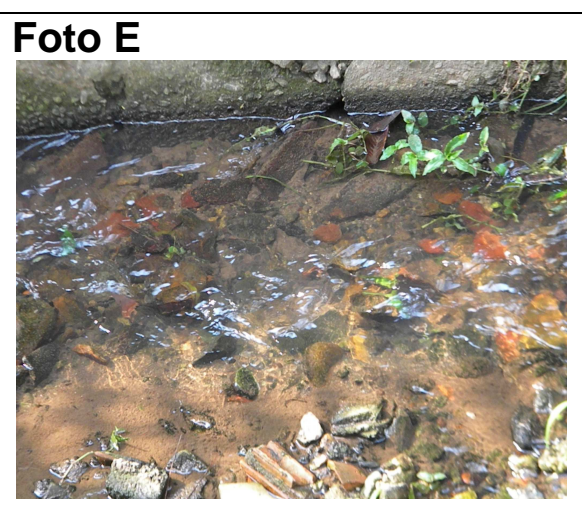
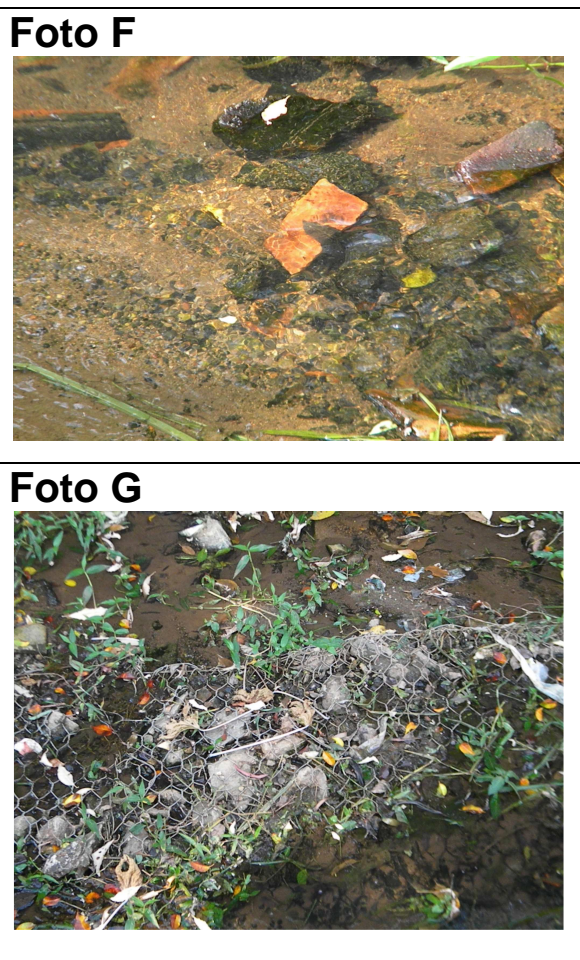

Ilustração 41 - Córrego Ibiraporã: Heterogeneidade do canal com relação ao tratamento de suas margens, fundo e a vegetação presente. Fonte: Fotos da autora. 
Em visita à área em 30/01/2013 observaram-se diversas novas ligações de esgoto no canal, que já apresentava uma regressão visual da qualidade de suas águas. Durante este registro fotográfico foi possível presenciar o lançamento de resíduos no córrego através de uma das GAP's que desemboca em sua nascente. Tal lançamento é de origem desconhecida, no entanto, pelo seu aspecto é possível intuir três fontes difusas prováveis: Primeira, pode-se supor que seja proveniente da lavagem de alguma residência na bacia que esteja passando por reformas que incluam pintura de sua alvenaria, cujos resíduos tenham sido lançados na sarjeta e que por consequência tenham sido direcionados ao córrego pelo sistema de drenagem; Segunda, pode-se atribuir a ocorrência também a uma ligação clandestina de esgoto na rede de drenagem pluvial; e Terceira, o lançamento direto em boca de lobo de resíduos de origem industrial ou comercial. A llustração 42 mostra duas fotos obtidas no mesmo local (Estaca 16) e no mesmo dia (30/01/2013), mas em um intervalo de poucos minutos; Na Foto B vemos o lançamento dos resíduos de origem desconhecida que poucos instantes antes não era observado, como se pode ver na Foto $A$.

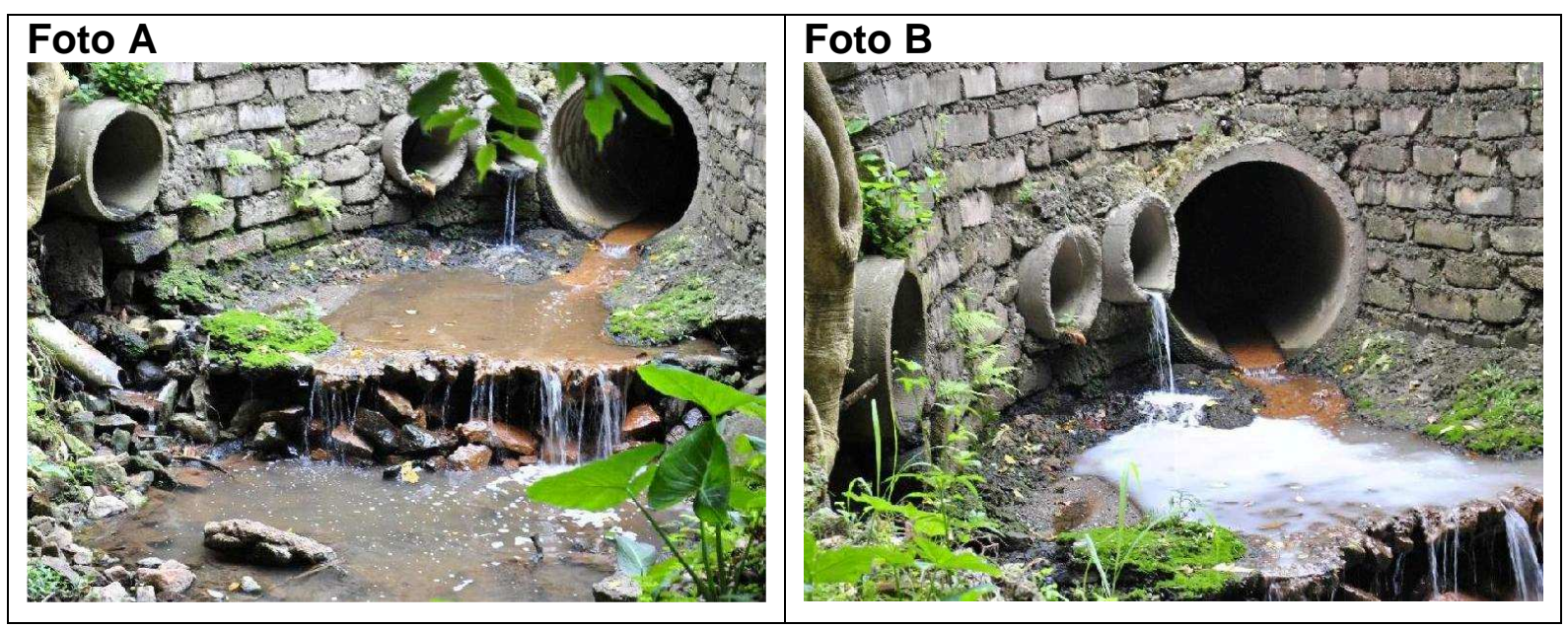

Ilustração 42 - Córrego Ibiraporã: Estaca 16 - Antes (Foto A) e depois (Foto B). Fonte: Fotos da autora.

Tal evento deixa clara a importância de ações em toda a bacia para manutenção do processo de recuperação do corpo d'água e ressalta ainda o quão complexo é o trabalho para controle da carga difusa. 


\subsection{CANALIZAÇÃO DOS CORPOS D'ÁGUA EM ESTUDO}

\subsubsection{Canalizações: Aspectos gerais}

Canalizações são intervenções feitas em corpos d'água, que podem contemplar a estabilização de suas margens e fundos, retificação de seu traçado, aumento das dimensões de suas seções bem como mudanças nas declividades de seus trechos. Tais intervenções devem estar de acordo com os critérios ambientais estabelecidos pela legislação e são autorizadas mediante concessão de uma outorga emitida pelo órgão competente. Neste item a discussão dará enfoque na estabilização de margens e fundos, uma vez que o objetivo é discutir sobre como o tratamento empregado afeta a qualidade ambiental do corpo d'água. Segundo Brighetti et al. (1999), para realizar a estabilização e proteção das margens e do fundo de canais pode se adotar duas alternativas, a utilização de revestimentos flexíveis ou proteções rígidas. A escolha destas duas alternativas se dá em função das características topográficas, do solo e da ocupação das margens do canal. Os itens seguintes descrevem brevemente cada metodologia.

\subsubsection{Revestimentos Flexíveis}

Revestimentos flexíveis são aqueles que se deformam sem perder suas características básicas. Os revestimentos flexíveis contemplam a utilização de proteção com enrocamentos, colchões, revestimentos vegetais naturais ou consolidados, gabiões de caixa e elementos do tipo saco de areia (BRIGHETTI et al., 1999). Geralmente são utilizados quando a faixa adjacente ao canal permite certo recalque, como por exemplo, faixas de solo com vegetação. A llustração 43 a seguir mostra fotos de canais tratados com os principais tipos de revestimentos flexíveis. 


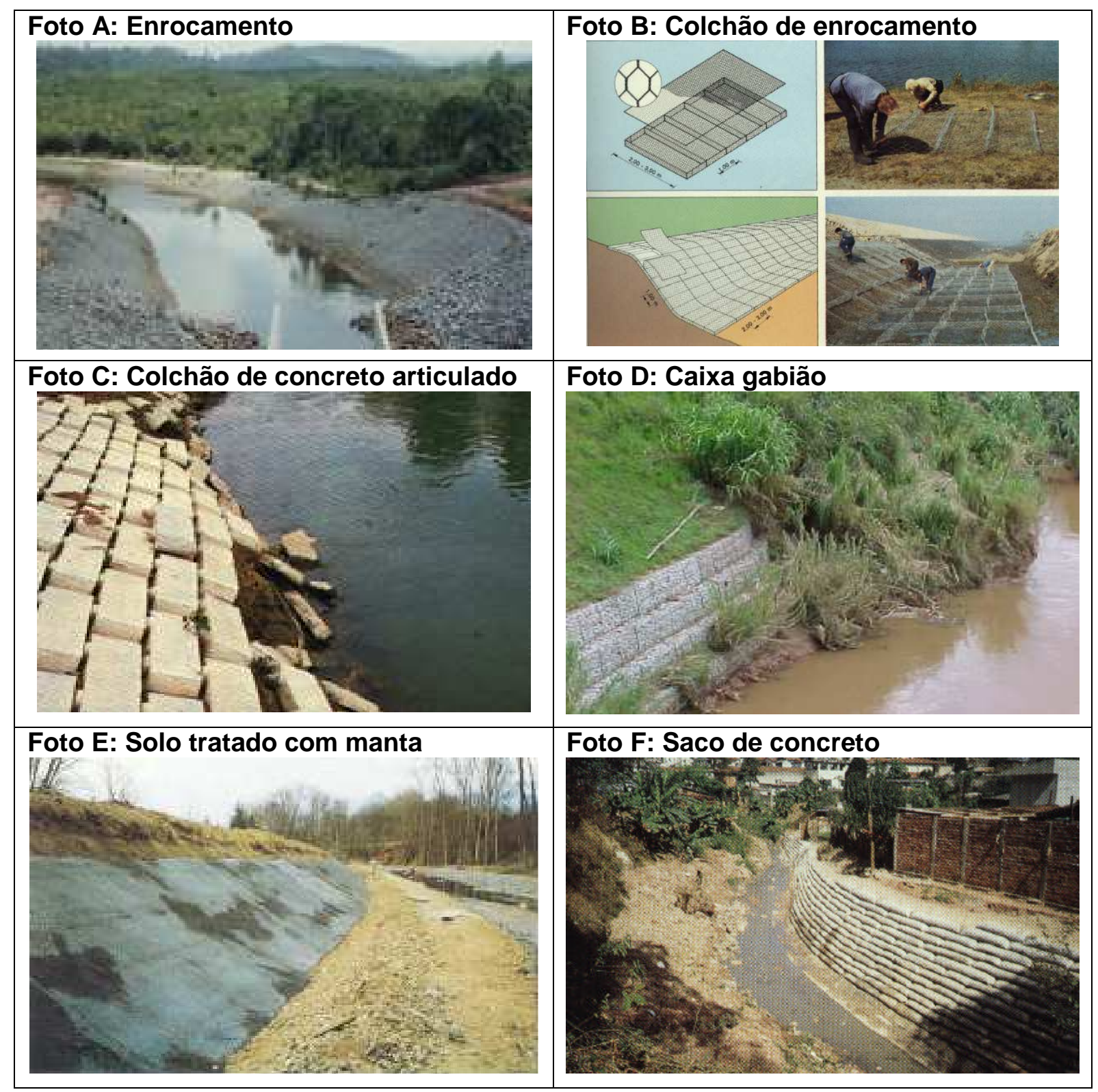

Ilustração 43 - Revestimentos flexíveis. Fonte: Adaptado de Brighetti et al.(1999).

\subsubsection{Proteções rígidas}

Proteções rígidas são aqueles que ao se deformarem tem suas características básicas alteradas. As proteções rígidas contemplam painéis de concreto armado, cortinas atirantadas, muros de gravidade e placas pré-moldadas de concreto (BRIGHETTI et al., 1999). Geralmente são utilizados quando a faixa adjacente ao canal não permite recalque do maciço contido, como por exemplo, quando o canal esta limitado diretamente por viário, cujo recalque resultaria em fraturas no pavimento. A llustração 44 a seguir a seguir mostra imagens dos principais tipos de proteções rígidas. 

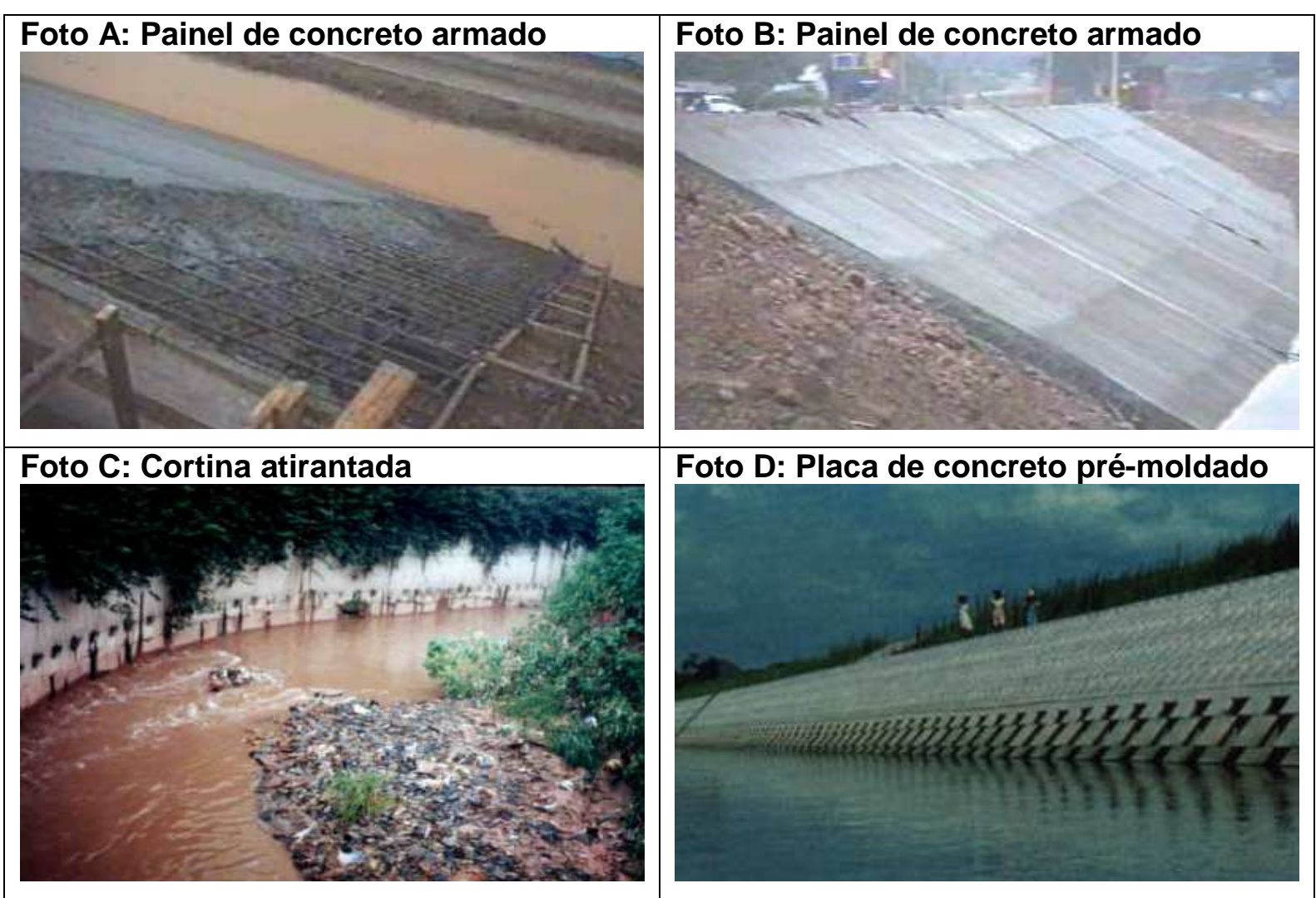

Ilustração 44 - Proteções rígidas. Fonte: Fonte: Adaptado de Brighetti et al.(1999).

\subsubsection{Canalização: Nascente do Sapé (Trecho 1 e 2) e Córrego Ibiraporã}

Os corpos d'água observados neste estudo possuem características distintas no que se refere ao tratamento de suas margens e fundos, o que merece atenção especial, uma vez que foram observados padrões distintos de qualidade ambiental decorrentes disso. Observou-se nos córregos em estudo os seguintes tipos de tratamento, apresentados na Tabela 08.

Tabela 08 - Tratamento das margens e fundo dos corpos d'água em estudo. Fonte: Elaborado pela autora.

\begin{tabular}{|c|c|c|c|}
\hline \multirow{2}{*}{ Corpo d'água } & \multicolumn{2}{|c|}{ Tratamento das margens } & \multirow{2}{*}{ Tratamento do fundo } \\
\hline & Direita & Esquerda & \\
\hline $\begin{array}{l}\text { Córrego lbiraporã - } \\
\text { Estaca } 16 \text { a } 12\end{array}$ & Solo tratado com manta & Solo tratado com manta & Enrocamento \\
\hline $\begin{array}{c}\text { Córrego lbiraporã - } \\
\text { Estaca } 12 \text { a } 06\end{array}$ & Solo tratado com manta & Caixa gabião & Colchão e enrocamento \\
\hline $\begin{array}{l}\text { Nascente do Sapé - } \\
\text { Estaca } 31 \text { a } 23\end{array}$ & Caixa gabião & Caixa gabião & Colchão \\
\hline $\begin{array}{l}\text { Córrego do Sapé - } \\
\text { Estaca } 23 \text { a } 12\end{array}$ & Caixa gabião & Caixa gabião & Enrocamento \\
\hline $\begin{array}{c}\text { Córrego do Sapé - } \\
\text { Estaca } 12 \text { a } 01\end{array}$ & Caixa gabião & Caixa gabião & Laje de concreto \\
\hline
\end{tabular}


Segundo agentes da prefeitura e do programa "Córrego Limpo", do ponto de vista da manutenção e limpeza, o pior tratamento do fundo de canais é o colchão, pois retém material grosseiro que fica preso às suas grades, impedindo também que os agentes de limpeza utilizem ferramentas auxiliares, limitando sua ação à limpeza manual. Com relação a isto, o tratamento mais indicado seria a laje de concreto, uma vez que permite a mecanização da limpeza. No entanto, do ponto de vista ambiental o resultados são diferentes, pois o uso da laje de concreto dificulta a manutenção de ecossistemas aquáticos diversos, uma vez que os organismos têm poucos lugares abrigados para colonizar. Já no caso do colchão, a grade acaba retendo resíduos, aumentando a matéria orgânica disponível, que acaba favorecendo a ação de organismos decompositores e diminuindo o oxigênio dissolvido disponível, que como já descrito é um fator limitante. Uma situação intermediária para os dois casos é o uso de enrocamento, pois permite maior versatilidade na manutenção e possibilita um ecossistema aquático mais diverso, uma vez que os organismos podem se abrigar no enrocamento. Portanto os melhores tratamentos do fundo do canal do ponto de vista ambiental e da manutenção e limpeza estão no Córrego Ibiraporã da Estaca 16 a 12 e no Córrego do Sapé da Estaca 23 a 12. 


\section{METODOLOGIA, RESULTADOS E DISCUSSÕES}

O estudo é composto por duas frentes investigativas, a fim de se avaliar a resposta dos corpos d'água em estudo frente à eliminação da carga pontual e a influência exercida pela carga difusa nestes corpos d'água em processo de recuperação. Desta forma, o estudo é composto pelas seguintes análises:

- Analisar a relevância da implantação de parques lineares como medida auxiliar à revitalização de corpos d'água;

- Analisar a eficiência do programa "Córrego Limpo" na despoluição dos córregos contemplados pelo programa;

- Análise da produção de carga difusa pelo método da UC (Unidade de Carga) das bacias dos córregos Ibiraporã e Nascente do Sapé, tornando possível avaliar a influência do potencial poluidor de cada uma delas sobre seus respectivos corpos d'água;

- Análise das variáveis físicas e químicas de tempo seco e tempo úmido, para avaliação da influência da carga difusa e caracterização da qualidade da água dos corpos d'água em estudo;

- Análise da comunidade bentônica através da aplicação dos índices de avaliação biológica; e

- Analisar a importância da utilização de indicadores físicos, químicos e biológicos na avaliação da qualidade da água.

Os itens a seguir descrevem a metodologia empregada em cada uma destas análises, bem como os resultados obtidos e as discussões pertinentes.

\subsection{DEMANDA BIOQUÍMICA DE OXIGÊNIO (DBO)}

Segundo o manual de procedimentos e técnicas laboratoriais do Laboratório de Saneamento da Escola Politécnica da Universidade de São Paulo (2004) a Demanda Bioquímica de Oxigênio (DBO) consiste em um teste empírico através de procedimentos padronizados, no qual é possível determinar a quantidade de oxigênio consumido em um determinado período de tempo em uma determinada amostra. Tal parâmetro pode ser utilizado para avaliar cargas poluidoras em corpos d'água, já que o oxigênio é item essencial para manutenção da vida. O método parte 
do principio simples de que todos os organismos vivos dependem do oxigênio direta ou indiretamente, desta forma, como toda matéria orgânica presente em um corpo d'água tende a ser mineralizada por organismos aeróbios, neste processo o oxigênio dissolvido no corpo d'água é absorvido, assim é possível quantificar através da DBO a quantidade de matéria orgânica presente na amostra. O método mais empregado para determinação da DBO é o da diluição, incubação em uma solução nutritiva e uma solução tampão para garantir o pH por volta de 6,5 a 7,5 por um período de 5 dias na ausência de luz a $20^{\circ} \mathrm{C}$, assim pode-se determinar os níveis iniciais e finais de oxigênio.

\subsubsection{Metodologia}

O monitoramento da DBO é realizado mensalmente pela SABESP, cuja análise é realizada em laboratório próprio e os resultados repassados para as respectivas unidades de negócio. O programa "Córrego Limpo" utiliza a DBO como indicador de qualidade da água nos corpos d'água pertencentes ao programa, desta forma eles são classificados de "condições naturais" a "poluídos" conforme a DBO apresentada, a Tabela 09 apresenta a caracterização utilizada pelo programa “Córrego Limpo", para classificar estes corpos d’água.

Tabela 09 - Caracterização dos Córregos em função da DBO. Fonte: Adaptado de Córrego Limpo (s/d).

\begin{tabular}{|c|l|}
\hline \multicolumn{2}{|c|}{ Caracterização dos Córregos em função da DBO Demanda Bioquímica de Oxigênio } \\
\hline $\mathbf{0}$ a $\mathbf{5} \mathbf{~ m g / l i t r o ~}$ & $\begin{array}{l}\text { Condições naturais, permite o contato primário das pessoas e a rega de } \\
\text { hortaliças }\end{array}$ \\
\hline $\mathbf{5}$ a $\mathbf{1 0} \mathbf{~ m g / l i t r o}$ & $\begin{array}{l}\text { Condições boas, já não se recomenda o contato primário nem a rega de } \\
\text { hortaliças, mas possibilita a existência de peixes, o uso da água para animais } \\
\text { e o tratamento convencional da água. }\end{array}$ \\
\hline $\mathbf{1 0}$ a $\mathbf{3 0} \mathrm{mg} /$ /litro & $\begin{array}{l}\text { Condições boas, aspecto estético bom, permite a existência de peixes, não } \\
\text { exala odores e possibilita o tratamento convencional da água. }\end{array}$ \\
\hline $\mathbf{3 0}$ a $\mathbf{7 0} \mathbf{~ m g / l i t r o ~}$ & $\begin{array}{l}\text { Condição estética ainda boa, porém com restrições a existência de peixes e } \\
\text { exalação de odores em determinadas épocas do ano (verão seco, } \\
\text { principalmente); tratamento de água com consumo alto de produtos químicos. }\end{array}$ \\
\hline$>\mathbf{7 0} \mathbf{~ m g / l i t r o ~}$ & Poluído. \\
\hline
\end{tabular}

O estudo do histórico do monitoramento da DBO fornecido pela SABESP permitiu avaliar a evolução da qualidade dos corpos d'água participantes do programa e o quão efetiva é a recuperação de corpos d'água através da eliminação de cargas pontuais. Neste estudo foi utilizado o histórico do monitoramento dos 
córregos pertencentes à zona oeste do município de São Paulo, devido à maior riqueza de dados obtidos junto à SABESP, sendo dado a esta análise dois enfoques:

a) Primeiro enfoque: Análise global, considerando o histórico de monitoramento de todos os córregos do programa pertencentes à zona oeste, tornando possível avaliar a eficiência do programa na remoção de cargas pontuais.

b) Segundo enfoque: Análise local, através da comparação entre o histórico de monitoramento da DBO da Nascente do Sapé e do Córrego Ibiraporã, permitindo a análise da relação desta variável com a produção de carga difusa nas bacias destes córregos. Além disto, tal análise possibilitou a avaliação da influência do programa de governança colaborativa na consolidação do processo de recuperação do Córrego Ibiraporã.

\subsubsection{Teste T}

Para avaliação da evolução da DBO nos córregos do programa foi utilizado o Teste T (Paramétrico) para dados pareados (antes e depois), que avalia a diferença entre as médias dos dados amostrais, ou seja, quanto maior o grau da diferença entre as médias, maior a significância das intervenções do programa. O teste pode ser aplicado através da Equação 1 a seguir.

$$
t=\frac{\bar{d}-\mu_{0}}{S_{d} / \sqrt{n}}
$$

(Equação 1 - ZAR, 1996)

Onde t é dado pela diferença entre as médias amostrais, menos a média das diferenças, dividido pelo desvio padrão da diferença entre as amostras, que por sua vez é dividido pela raiz quadrada no número de amostras da população amostral.

\subsubsection{Pearson ( $\rho)$}

Para testar a correlação linear entre duas variáveis é possível utilizar o coeficiente de relação de Pearson ( $\rho$ ) que mede o grau de relação entre duas variáveis e a direção dessa correlação (Positiva ou negativa), podendo resultar em valores entre -1 e 1 , onde se: $\rho=1$; há correção perfeita e positiva entre as duas 
variáveis; $\rho=-1$; há correção perfeita e negativa entre as duas variáveis, ou seja, à medida que uma diminui a outra aumenta; e $\rho=0$; não há correlação linear entre as duas variáveis, mas pode haver uma dependência não linear. O coeficiente de relação de Pearson ( $\rho$ ) é calculado pela Equação 2 apresentada a seguir.

$$
\rho=\frac{\sum_{i=1}^{n}\left(x_{i}-\bar{x}\right)\left(y_{i}-\bar{y}\right)}{\sqrt{\sum_{i=1}^{n}\left(x_{i}-\bar{x}\right)^{2}} \cdot \sqrt{\sum_{i=1}^{n}\left(y_{i}-\bar{y}\right)^{2}}}=\frac{\operatorname{cov}(X, Y)}{\sqrt{\operatorname{var}(X) \cdot \operatorname{var}(Y)}}
$$

(Equação 2 - ZAR, 1996)

Considerando que a precipitação tem o poder de diluir a matéria orgânica presente no corpo d'água e por consequência reduzir a DBO deste, é relevante testar a correlação entre a Precipitação e a DBO e esperas-e, portanto que haja uma correlação linear negativa entre estas variáveis, sendo esta correlação negativa mais pronunciada em corpos d'água que estejam sobre forte influência de cargas pontuais (Principal provedora de matéria orgânica para um corpo d'água em áreas urbanas) e menos significativa em corpos d'água sobre baixa influência, como naqueles que já foram atendidos pelo programa.

\subsubsection{Resultados e discussões}

\subsubsection{Análise global}

\subsection{Evolução da DBO nos córregos do programa}

Para avaliação global da evolução da DBO nos córregos do programa "Córrego Limpo" foi utilizado o histórico do monitoramento da DBO, fornecido pela SABESP, dos córregos pertencentes à primeira, segunda e terceira etapa do programa, localizados na zona oeste do município de São Paulo. Desta forma, os dados foram divididos em dois grupos:

- Primeiro grupo: constituído com os dados dos córregos do programa cujas ações estão em estado inicial, ou seja, ainda aqueles sob influência de cargas pontuais, sendo eles: Córrego Antonico, Córrego Esmeralda, Córrego Itapaiúna e Córrego Ribeirão dos Pires; e

- Segundo grupo: constituído por aqueles cujas ações de despoluição, ou seja, o processo para eliminação das cargas pontuais foi concluído, sendo eles: 
Nascente do Sapé, Córrego José de Araújo, Córrego Caxingui, Córrego Corveta e Córrego Ibiraporã.

O Gráfico da llustração 45 mostra a relação entre a precipitação e a DBO média para os dois grupos. Neste Gráfico pode-se observar a redução significativa da DBO nos córregos onde as intervenções do programa foram concluídas, além disso, é perceptível a variação da DBO ao longo do ano em função das mudanças no regime das precipitações principalmente nos córregos sob ainda forte influência de cargas pontuais.

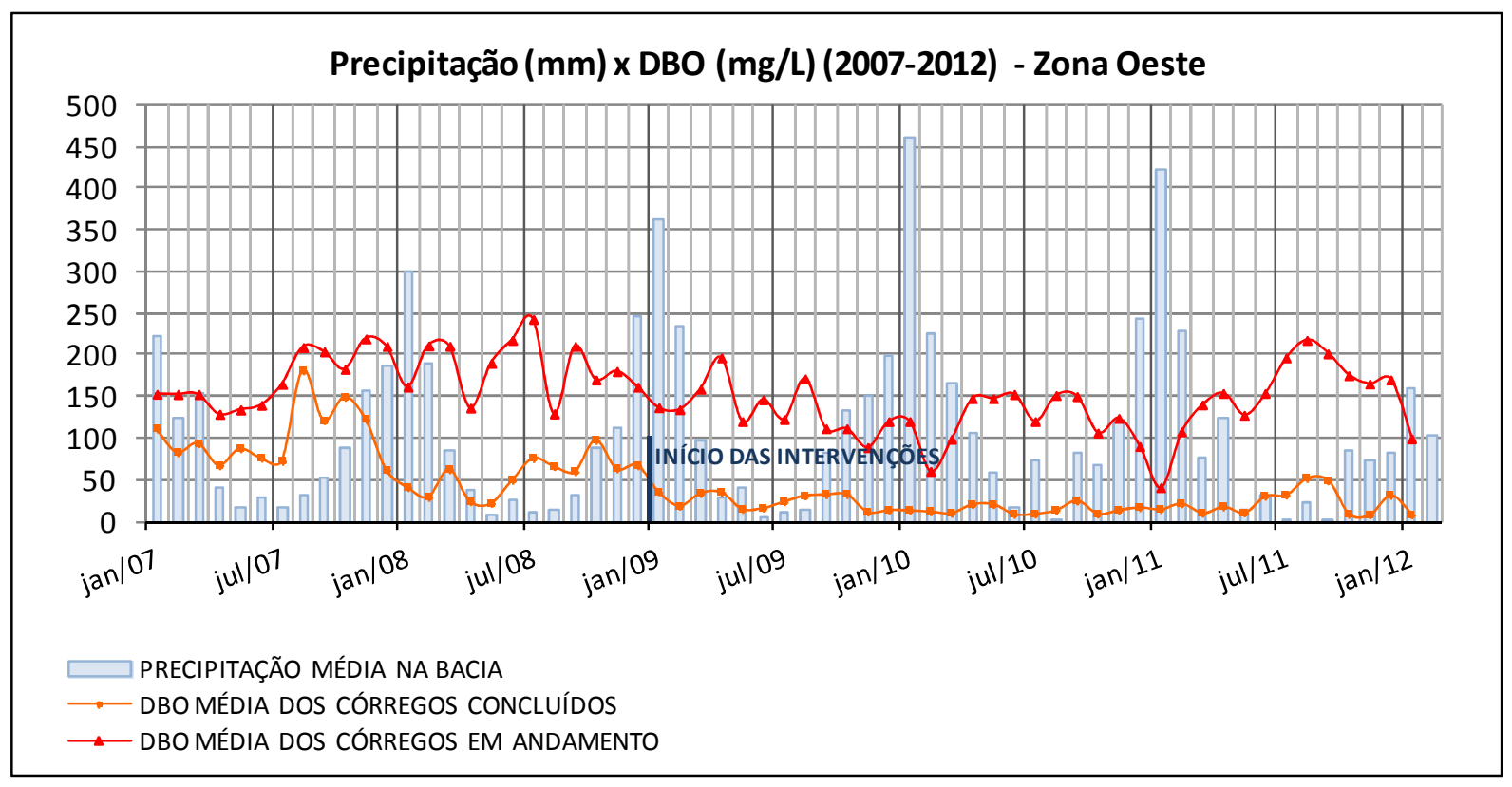

llustração 45 - Relação entre a Precipitação $(\mathrm{mm})$ e a Demanda Bioquímica de Oxigênio (DBO) no período de 01/01/2007 a 01/01/2012 nos córregos da Zona Oeste pertencentes ao programa "Córrego Limpo". Fonte: Elaborado pela autora a partir de Córrego Limpo (s/d) e SAISP (2012).

\subsection{Eficiência do programa na redução da DBO: Teste T}

É possível avaliar a eficiência da recuperação dos corpos d'água do programa através da comparação entre a DBO no período anterior às intervenções do programa e após as intervenções nos corpos d'água, tomando como base os córregos já atendidos pelo programa.

Para realizar tal comparação é possível utilizar o teste $T$, que calcula o grau de diferença entre as médias obtidas nos dois períodos. Utilizou-se para tal avaliação o histórico da DBO dos seguintes corpos d'água: Nascente do Sapé, 
Córrego José de Araújo, Córrego Caxingui, Córrego Corveta e Córrego Ibiraporã. Desta forma foram utilizados dois grupos de dados, sendo o primeiro constituído pelas as médias da DBO no período anterior às intervenções do programa, (Jan/2007 a Dez/2008); e o segundo pelas médias da DBO após a conclusão das intervenções do programa, (Jan/2010 a Dez/2011). Excluíram-se, portanto, as medições feitas durante a execução das obras de intervenção (Jan/2009 a Dez/2009), considerando somente a situação antes e depois do processo de despoluição. A Tabela 10, a seguir, mostra as DBO's médias mensais bem como as diferenças calculadas para os dois períodos.

Tabela 10 - Dados base para aplicação do teste T para avaliação da eficiência do programa na redução da DBO nos corpos d'água em questão. Fonte: Elaborado pela autora.

\begin{tabular}{|c|c|c|c|c|c|c|c|c|c|c|c|c|}
\hline \multirow{2}{*}{$\begin{array}{c}\text { ANTES: DBO } \\
(\mathrm{mg} / \mathrm{L})\end{array}$} & - -07 & $v-07$ & ar-07 & abr-07 & & jun-07 & jul-07 & ago-07 & set-07 & out -07 & nov-07 & ez-07 \\
\hline & & & & & & & & & & & & \\
\hline \multirow{2}{*}{$\begin{array}{c}\text { DEPOIS: } \\
\text { DBO (mg/L) }\end{array}$} & jan-10 & $2 v-10$ & ar-10 & abr-10 & $\mathrm{i}-10$ & jun-10 & $1-10$ & & & & & \\
\hline & 13,00 &, 50 & & 20,25 &, 25 & 8,50 & 9,00 & 13,25 & & 0 & 50 & 16,50 \\
\hline DIFERENÇAS & 97,75 &, 00 & 3,75 & 46,75 & 66,75 & 67,25 & 63,00 & 167,25 & 96,00 & 139,75 & 108,75 & 45,00 \\
\hline \multirow{2}{*}{$\begin{array}{c}\text { ANTES: DBO } \\
(\mathrm{mg} / \mathrm{L})\end{array}$} & jan-08 & fev-08 & mar-08 & $a b r-08$ & mai-08 & jun-08 & jul-08 & ago-08 & set-08 & out-08 & nov-08 & dez-0 \\
\hline & 40,75 & 00 & 23 & 23,50 &, 50 & 49,00 & 75,50 & 65,75 & 59,50 & 97,25 & 62,75 & 67,00 \\
\hline \multirow{2}{*}{$\begin{array}{c}\text { DEPOIS: } \\
\text { DBO (mg/L) }\end{array}$} & jan-11 & fev-11 & mar-11 & $a b r-11$ & ai-11 & jun-11 & jul-11 & ago-11 & set-11 & out-11 & nov-11 & dez-11 \\
\hline & 14,25 & & & & & 30,00 & 31,50 & 51,75 & 48,75 & & & 1,25 \\
\hline DIFERENÇAS & 26,50 & 7,75 & 52,48 & 6,00 & 11,25 & 19,00 & 44,00 & 14,00 & 10,75 & 88,75 & 54,75 & 35,75 \\
\hline
\end{tabular}

Adota-se como Hipótese para 0 teste $T$ paramétrico o seguinte: $\mathrm{H}_{0}=$ as intervenções não surtiram efeito sobre a DBO. Aplicando então o teste temos os seguintes resultados: média entre as diferenças entre o grupo antes e depois de 65,86; erro padrão de 9,63; e valor obtido para $T$ de 6,84. Assim para o nível de significância 0,05 e grau de liberdade 23, pela Tabela de T crítico de Student (ZAR,1996), obtemos o $T$ crítico de 1,714. Portanto, rejeita-se a hipótese $H_{0}$ adotada, ou seja, sendo o $\mathrm{T}$ obtido 6,84 e o $\mathrm{T}$ crítico 1,714 há efeito considerável das intervenções do programa sobre a DBO dos córregos em questão atendidos pelo programa. Portanto podemos concluir que as ações do programa são de extrema importância para o processo de recuperação destes corpos d'água, considerando os impactos causados pelo excesso de matéria orgânica nestes. 


\subsection{Correlação linear entre a DBO e a precipitação}

Foram utilizados para esta avaliação a DBO média dos corpos d'água cujas ações do programa ainda estão em andamento e a DBO média dos corpos d'água cujas ações do programa já foram concluídas. Assim, aplicando o coeficiente de relação de Pearson ( $\rho$ ) para as variáveis "Precipitação" e "DBO", obtemos os seguintes resultados, apresentados na Tabela 11.

Tabela 11 - Coeficientes de relação de Pearson obtidos para os córregos da zona oeste. Fonte: Elaborado pela autora.

\begin{tabular}{|l|c|}
\hline \multicolumn{2}{|c|}{ Coeficiente de relação de Pearson $(\boldsymbol{\rho})$} \\
\hline$P \times$ DBO Média dos Concluidos & $-0,21$ \\
\hline$P \times$ DBO Média dos em andamento & $-0,42$ \\
\hline
\end{tabular}

Como era esperado, há uma correlação linear negativa entre as duas variáveis, ou seja, com o aumento da precipitação há a diminuição da DBO, bem como há seu aumento com a redução da precipitação. Além disso, confirmou-se a hipótese de que a correlação linear negativa nos córregos sobre influência de cargas pontuais (Em andamento) seria mais elevada do que nos corpos d'água sobre baixa influência de cargas pontais (Concluídos).

\subsubsection{Análise local}

Para uma análise mais detalhada do processo de eliminação da carga pontual nos córregos do programa foi realizada uma análise local utilizando o histórico do monitoramento da DBO do Córrego lbiraporã e da Nascente do Sapé. Tal análise é descrita nos itens seguintes.

\subsection{Evolução da DBO: Nascente do Sapé}

Apesar da redução significativa na DBO do corpo d'água, devido à ausência de gestão participativa na bacia, a bacia possui um alto potencial poluidor, o que faz com que haja maior oscilação nos valores da DBO da Nascente, mesmo depois das ações do programa. Há relatos por parte dos moradores das áreas próximas ao canal de despejos clandestinos, provavelmente de origem industrial, que fazem com que em determinados dias haja mudança brusca na qualidade da água do córrego (Mudança de cor, turbidez e temperatura). Analisando o histórico do monitoramento 
da DBO do corpo d'água podemos observar um outlier nos meses de agosto e setembro de 2011, a SABESP informou que essa mudança brusca na DBO se deveu a um vazamento de esgotos domésticos durante a realização de uma de suas intervenções na área, nestes meses a DBO da nascente chegou a atingir $170 \mathrm{mg} / \mathrm{L}$, devido a elevada presença de matéria orgânica, característica do esgoto doméstico. O Gráfico da llustração 46 mostra a evolução da DBO na Nascente do Sapé, onde podemos notar a redução significativa da DBO após a conclusão das intervenções do programa ao final de 2009.

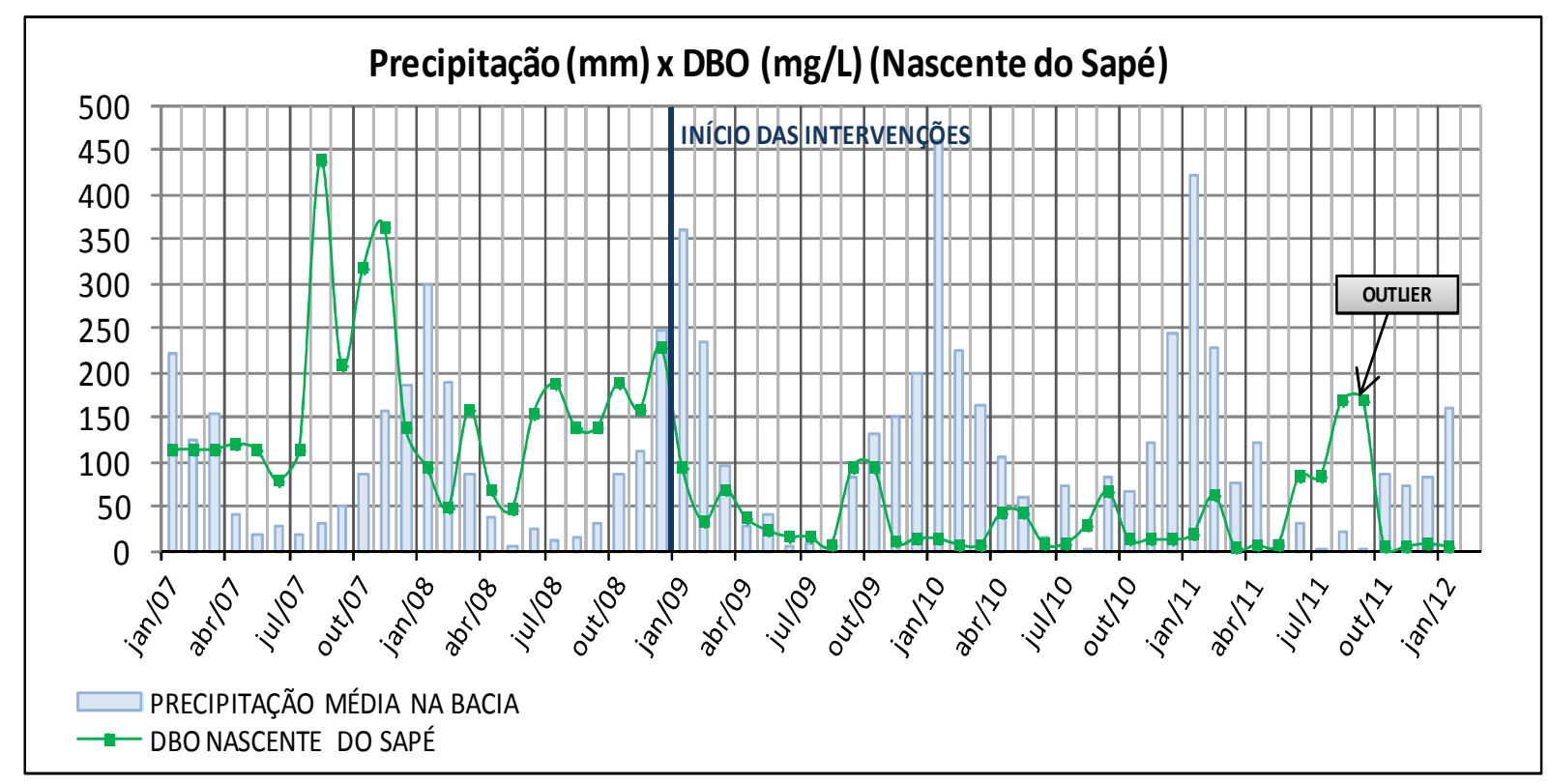

llustração 46 - Relação entre a Precipitação $(\mathrm{mm})$ e a Demanda Bioquímica de Oxigênio (DBO) na Nascente do Sapé no período 01/01/2007 a 01/01/2012. Fonte: Elaborado pela autora a partir de Córrego Limpo (s/d) e SAISP (2012).

É possível então realizar um estudo mais detalhado a fim de identificar a origem das discrepâncias apresentada pela DBO no período monitorado. Para tanto é possível utilizar valores de referencia para a DBO de diferentes tipologias, como os apresentados na Tabela 12, que mostra valores característicos para concentração média de poluentes segundo Lima (1998) e Larentis (2004) para diferentes tipologias. 
Tabela 12 - Concentração média estimada de poluentes por tipologia - Fonte: Adaptado pela autora de Lima (1998) e Larentis (2004).

\begin{tabular}{|l|c|c|c|c|}
\hline \multicolumn{5}{|c|}{ Concentração Média de poluentes (mg/L) por tipologia } \\
\hline Tipo & DBO & $\begin{array}{c}\text { Nitrogênio } \\
\text { Total }\end{array}$ & Fósforo Total & $\begin{array}{c}\text { Coliformes } \\
\text { Fecais }\end{array}$ \\
\hline Couros & 210 & 3,3 & 2 & 1 \\
\hline Bebidas & 350 & 10 & 1 & 0,2 \\
\hline Têxtil & 22 & 27,5 & 1,2 & 8 \\
\hline Alimentos & 260 & 30 & 5 & 7 \\
\hline Química & 146 & 27,5 & 1,1 & 0,001 \\
\hline Metal & 10 & 2,6 & 0,6 & 0,001 \\
\hline Papel & 250 & 10 & 1,2 & 0,001 \\
\hline Esgoto Doméstico & 350 & 25 & 9 & \\
\hline Utilidade Pública & 300 & 30 & 10 & 7 \\
\hline
\end{tabular}

Nesta tabela podemos verificar que esgotos domésticos podem atingir DBO's médias elevadas de até $300 \mathrm{mg} / \mathrm{L}$, valor condizente com a DBO obtida no córrego no período em que este estava sobre influência do vazamento mencionado pela concessionária. Além disso, através desta tabela é possível verificar o possível tipo de interferência que estaria afetando a DBO da Nascente do Sapé nos demais momentos em que o valor obtido para a DBO fica acima do esperado, pois depois das ações do programa a DBO da nascente ficou controlada apresentando valores menores que $15 \mathrm{mg} / \mathrm{L}$, exceto nestes períodos específicos, onde a DBO atingiu valores de 24 a 95mg/L evidenciando uma possível irregularidade. Podemos atribuir tal discrepância a lançamentos clandestinos de origem industrial, baseando se em duas premissas: primeira, a tabela mostra que efluentes de indústrias apresentam DBO média semelhante aos valores obtidos; e segundo, a bacia situa-se em uma região caracterizada pela elevada concentração de unidades industriais devido à proximidade com a Rodovia Raposo Tavares.

Ressalta-se então a importância do controle da carga pontual, não só como um elemento de melhoria na qualidade ambiental urbana, mas também uma ferramenta para gestão de recursos hídricos, uma vez que esta facilita a detecção de lançamentos de esgotos in natura de diversas origens nos corpos d'água, tornando possível inclusive intuir o tipo de tipologia que o gerou, como foi feito para a Nascente do Sapé neste item. O lançamento de esgotos in natura em um corpo d'água constitui crime ambiental e a prática é passível de sanções legais, mas 
muitas vezes tais lançamentos ficam ocultos sobre a predominância da influência dos esgotos domésticos, portanto o programa atua indiretamente na inibição de tal prática.

\subsection{Evolução da DBO: Córrego lbiraporã}

O Córrego lbiraporã, graças ao programa de governança colaborativa, tem seu processo de despoluição mais consolidado, uma vez que o potencial poluidor da bacia encontra-se minimizado pela implementação das ações do programa. $O$ Gráfico da llustração 47 mostra a evolução da DBO no Córrego lbiraporã, onde se pode observar a redução significativa na DBO e a estabilidade no monitoramento da mesma. Podemos observar, assim como no histórico da Nascente do Sapé, um outlier em julho de 2011, segundo informações da SABESP, também é resultado de um vazamento de esgotos sanitário durante a execução de intervenções na área.

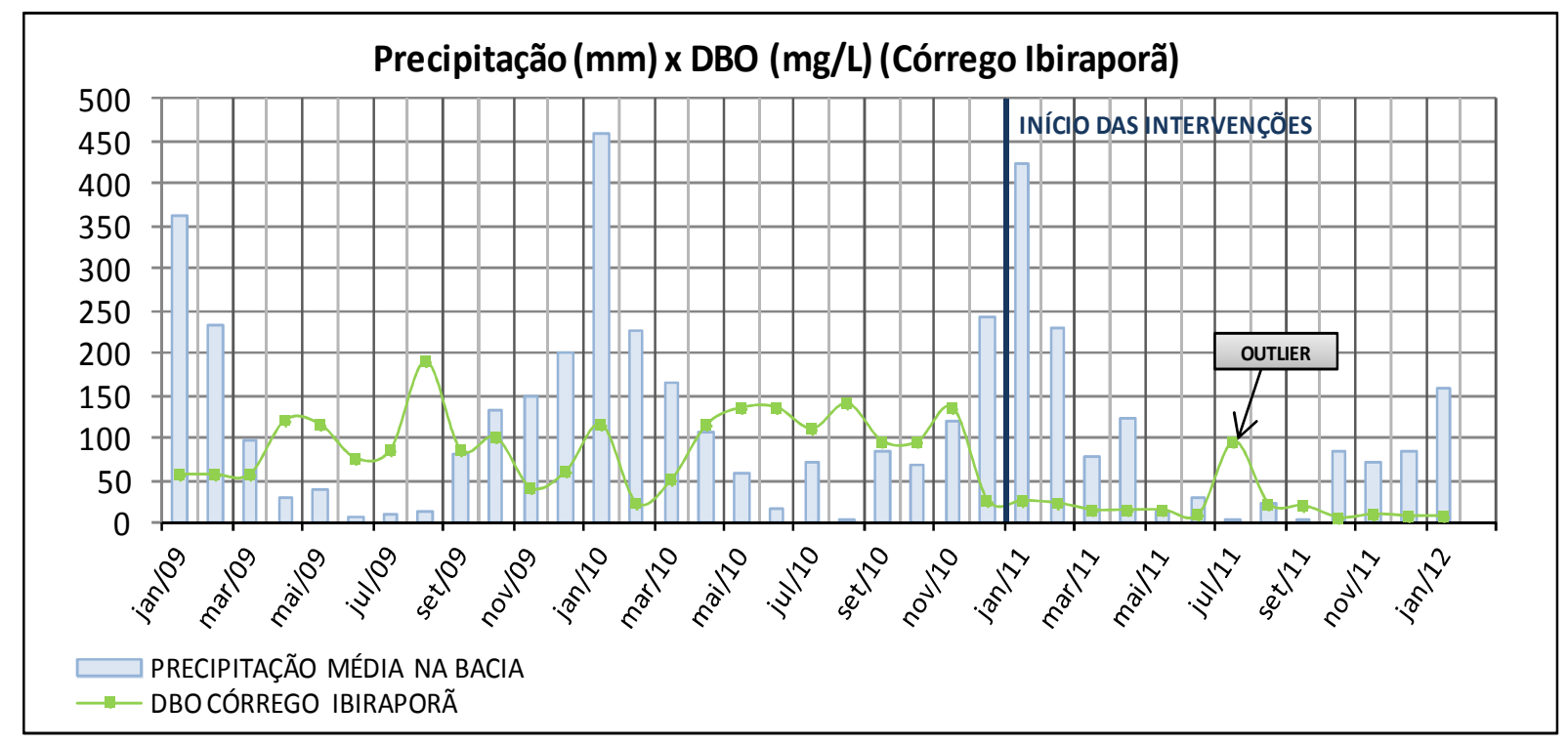

llustração 47 - Relação entre a Precipitação $(\mathrm{mm})$ e a Demanda Bioquímica de Oxigênio (DBO) no Córrego Ibiraporã no período 01/01/2007 a 01/01/2012. Fonte: Elaborado pela autora a partir de Córrego Limpo (s/d) e SAISP (2012).

Comparando a DBO do período pós-intervenção dos dois corpos d'água foco do estudo, Nascente do Sapé e Córrego Ibiraporã, é possível observar as flutuações na DBO monitorada nas duas áreas, ficando clara a maior estabilidade apresentada no monitoramento do Córrego Ibiraporã. 


\subsection{Teste T: Nascente do Sapé e Córrego Ibiraporã}

Para avaliação da eficiência da remoção da DBO para o Córrego Ibiraporã e a Nascente do Sapé, foi aplicado o teste $T$, onde primeiramente foi determinada a diferença entre a população amostral da DBO antes e depois das intervenções do programa. Sendo para o Córrego Ibiraporã antes das intervenções o período de Jan/2009 a Dez/2009 e depois o período de Jan/2011 a Dez/2011. Já para a Nascente do Sapé antes das intervenções compreendeu o período de Jan/2008 a Dez/2008 e depois o período de Jan/2010 a Dez/2010. Portanto para este teste estatístico, também foi desconsiderado o monitoramento da DBO no período de execução das obras e ações do programa, sendo considerados para ambos os casos doze meses antes das intervenções e doze meses após as intervenções. $\mathrm{Na}$ Tabela 13 são mostradas as diferenças calculadas, bem como a DBO obtida nos períodos em questão.

Tabela 13 - DBO5, 20 no período anterior às intervenções do programa e após a conclusão das intervenções do programa para os córregos Ibiraporã e Nascente do Sapé. Fonte: Elaborado pela autora.

\begin{tabular}{|c|c|c|c|c|c|c|c|c|c|c|c|c|}
\hline \multicolumn{10}{|c|}{ Córrego lbiraporã } \\
\hline Antes (2009) & 56 & 56 & 56 & 120 & 115 & 75 & 85 & 190 & 85 & 100 & 40 & 60 \\
\hline Depois (2011) & 25 & 22 & 14 & 14 & 14 & 9 & 95 & 21 & 19 & 5 & 9 & 7 \\
\hline Diferença & 31 & 34 & 42 & 106 & 101 & 66 & -10 & 169 & 66 & 95 & 31 & 53 \\
\hline \multicolumn{10}{|c|}{ Nascente do Sapé } \\
\hline Antes (2008) & 95 & 50 & 160 & 70 & 48 & 155 & 189 & 140 & 140 & 190 & 160 & 230 \\
\hline Depois (2010) & 15 & 8 & 8 & 44 & 44 & 9 & 9 & 30 & 68 & 14 & 14 & 14 \\
\hline Diferença & 80 & 42 & 152 & 26 & 4 & 146 & 180 & 110 & 72 & 176 & 146 & 216 \\
\hline
\end{tabular}

Adota-se como Hipótese para o teste $T$ paramétrico o seguinte: $\mathrm{H}_{0}=$ as intervenções não surtiram efeito sobre a DBO. Para os dois casos os resultados foram: $T$ para o Córrego Ibiraporã $=4,819$ e $T$ para a Nascente do Sapé $=5,778$. Assim para o nível de significância 0,05 e grau de liberdade 23, pela tabela de T crítico de Student (ZAR,1996), obtemos o T crítico de 1,714. Portanto, rejeita-se a hipótese $\mathrm{H}_{0}$ adotada para os dois casos, ou seja, sendo o T obtido 4,819 e 5,778 e o T crítico 1,714 , há efeito considerável das intervenções do programa sobre a DBO dos dois córregos em questão, no entanto, com magnitude distintas. Avaliando os T's obtidos para os dois casos, podemos concluir que o T obtido para a Nascente do 
Sapé foi maior devido ao elevado potencial poluidor da bacia, uma vez que antes do programa o corpo d'água encontrava-se mais impactado que o Córrego do lbiraporã em período semelhante, portanto as ações do programa surtiram um efeito mais considerável. Já o Córrego Ibiraporã, devido ao menor potencial poluidor de sua bacia, encontrava-se em melhores condições mesmo antes das intervenções, portanto as intervenções do programa tiverem um impacto na DBO menor se comparado à Nascente do Sapé.

\subsection{Correlação linear entre a DBO e a precipitação}

Foram utilizados para esta avaliação a DBO média dos dois corpos d'água. Assim, aplicando o coeficiente de relação de Pearson ( $\rho)$ para as variáveis Precipitação e DBO, obtemos os seguintes resultados, apresentados na Tabela 14.

Tabela 14 - Coeficientes de relação de Pearson obtidos para os córregos lbiraporã e Nascente do Sapé da zona oeste. Fonte: Elaborado pela autora.

\begin{tabular}{|l|l|}
\hline Coeficiente de relação de Pearson $(\boldsymbol{\rho})$ \\
\hline x DBO Sapé & $-0,34$ \\
\hline P D DBO Ibiraporã & $-0,11$ \\
\hline
\end{tabular}

Como era esperado, há uma correlação linear negativa entre as duas variáveis para os dois casos. Além disso, mais uma vez confirmou-se a hipótese de que a correlação linear negativa nos córregos sobre maior influência de cargas pontuais, caso da Nascente do Sapé, é mais elevada do que nos corpos d'água sobre menor influência de cargas pontuais, caso do Córrego lbiraporã.

Podemos visualizar essa correlação linear negativa muito marcante em corpos d'água de ordens elevadas, como é o caso do rio Tietê e Pinheiros no município de São Paulo. Os Gráficos na llustração 48 e na llustração 49, a seguir, mostram a evolução da DBO nos Rios Tietê e Pinheiros ao longo de períodos secos e chuvosos de agosto de 2007 a janeiro de 2010, onde podemos observar 0 comportamento sazonal da DBO, sendo mais alta no período seco e mais baixa no período chuvoso. Tal processo se deve à diluição da carga poluidora pela precipitação. 


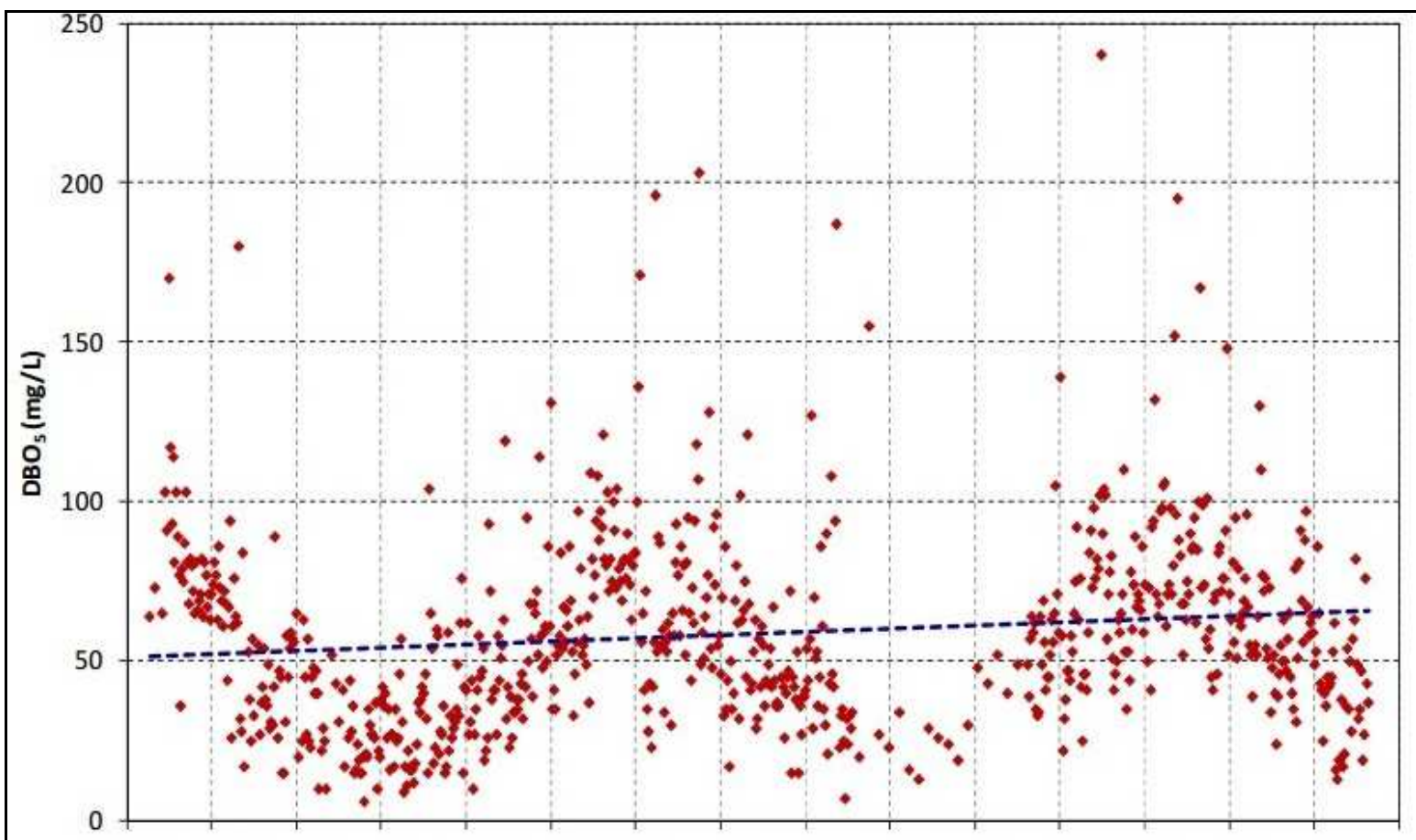

ago/07 out/07 dez/07 fev/08 abr/08 jun/08 jul/08 set/08 nov/08 jan/09 mar/09 mai/09 jul/09 set/09 nov/09 jan/10

Mês/ano

llustração 48 - DBO do Rio Tietê no período de agosto de 2007 a dezembro de 2009. Fonte: Porto (s/d).

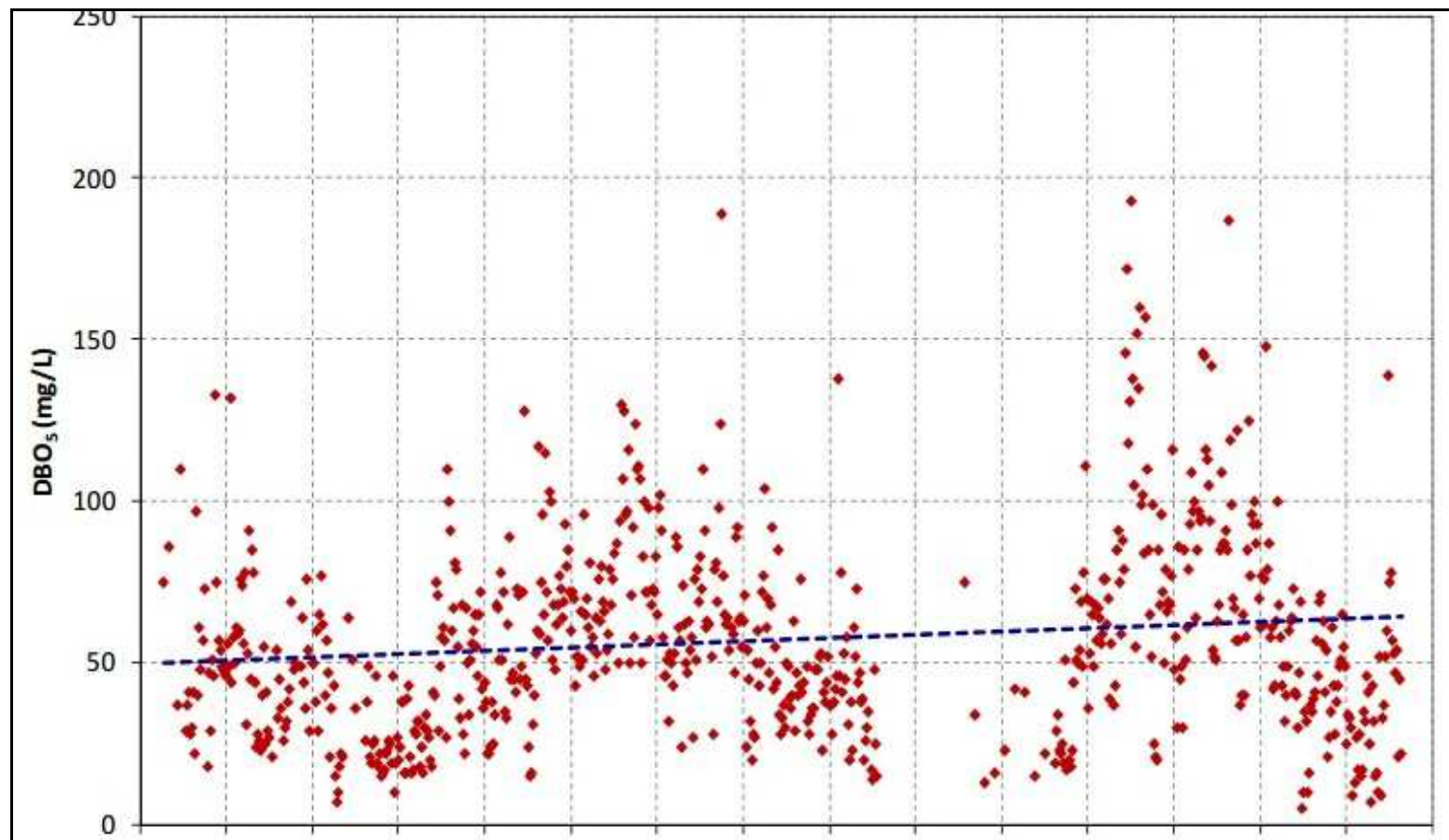

ago/07 out/07 dez/07 fev/08 abr/08 jun/08 jul/08 set/08 nov/08 jan/09 mar/09 mai/09 jul/09 set/09 nov/09 jan/10 Mês/ano

llustração 49 - DBO do Rio Pinheiros no período de agosto de 2007 a dezembro de 2009. Fonte: Porto (s/d). 


\subsubsection{Recuperação dos corpos d'água em estudo}

Através da média aparada (Importante no caso do Córrego lbiraporã devido à discrepância apresentada no mês de julho, já que elimina outliers - valores discrepantes) tem-se para o Córrego lbiraporã a DBO média de $14 \mathrm{mg} / \mathrm{L}$ no ano de 2011. Tem-se ainda que, segundo Larentis (2004), o valor da DBO para carga difusa no ambiente urbano é por volta de $12 \mathrm{mg} / \mathrm{L}$, como mostrado na Tabela 15 , a seguir. Fazendo assim a comparação entre a DBO média observada no Córrego lbiraporã e a monitorada por Larentis (2004), podemos concluir que a DBO apresentada pode ser atribuída em grande parte à carga difusa trazida pelo escoamento superficial da bacia, confirmando a eficiência do programa na remoção das cargas pontuais.

Tabela 15 - Concentração média estimada para poluição difusa (Adaptado de Larentis, 2004). Fonte: Elaborado pela autora.

\begin{tabular}{|l|c|c|c|}
\hline \multicolumn{4}{|c|}{ Concentração Média estimada para poluição difusa (mg/L) } \\
\hline \multicolumn{1}{|c|}{ Tipo } & DBO $_{5}$ & Nitrogênio Total & Fósforo Total \\
\hline Urbano & 12 & 2,2 & 0,7 \\
\hline Agrícola & 6 & 0,8 & 0,15 \\
\hline Pastagem & 3 & 0,8 & 0,1 \\
\hline Floresta & 1 & 0,8 & 0,1 \\
\hline Água & 0 & 0 & 0 \\
\hline
\end{tabular}

A resolução CONAMA 357 (2005), que dispõe sobre a classificação de corpos d'água e diretrizes ambientais para enquadramento, prevê no caso de corpos d'água de água doce as seguintes condições de DBO para cada classe, apresentadas na Tabela 16, a seguir.

Tabela 16 - DBO para diferentes classes de corpos d'água de água doce. Fonte: Elaborado pela autora a partir da CONAMA 357 (2005).

\begin{tabular}{|l|c|}
\hline \multicolumn{2}{|c|}{ DBO para diferentes classes (mg/L) } \\
\hline Classe Especial & Condições Naturais \\
\hline Classe I & 3,00 \\
\hline Classe II & 5,00 \\
\hline Classe III & 10,00 \\
\hline
\end{tabular}

Portanto, o efetivo controle das cargas pontuais em corpos d'água urbanos, como no caso do Córrego lbiraporã, pode resultar no atendimento do padrão de DBO estabelecido pela CONAMA 357 para a classe II, como podemos ver através do gráfico da llustração 50. Considerando ainda que em média aproximadamente 
$12 \mathrm{mg} / \mathrm{L}$ desta DBO seja proveniente da carga difusa, como vimos na Tabela 15, o controle desta carga poderia resultar no atendimento do padrão de DBO estabelecido para a classe I em alguns meses do ano, evidenciando assim a importância do controle deste tipo de poluição no meio urbano.

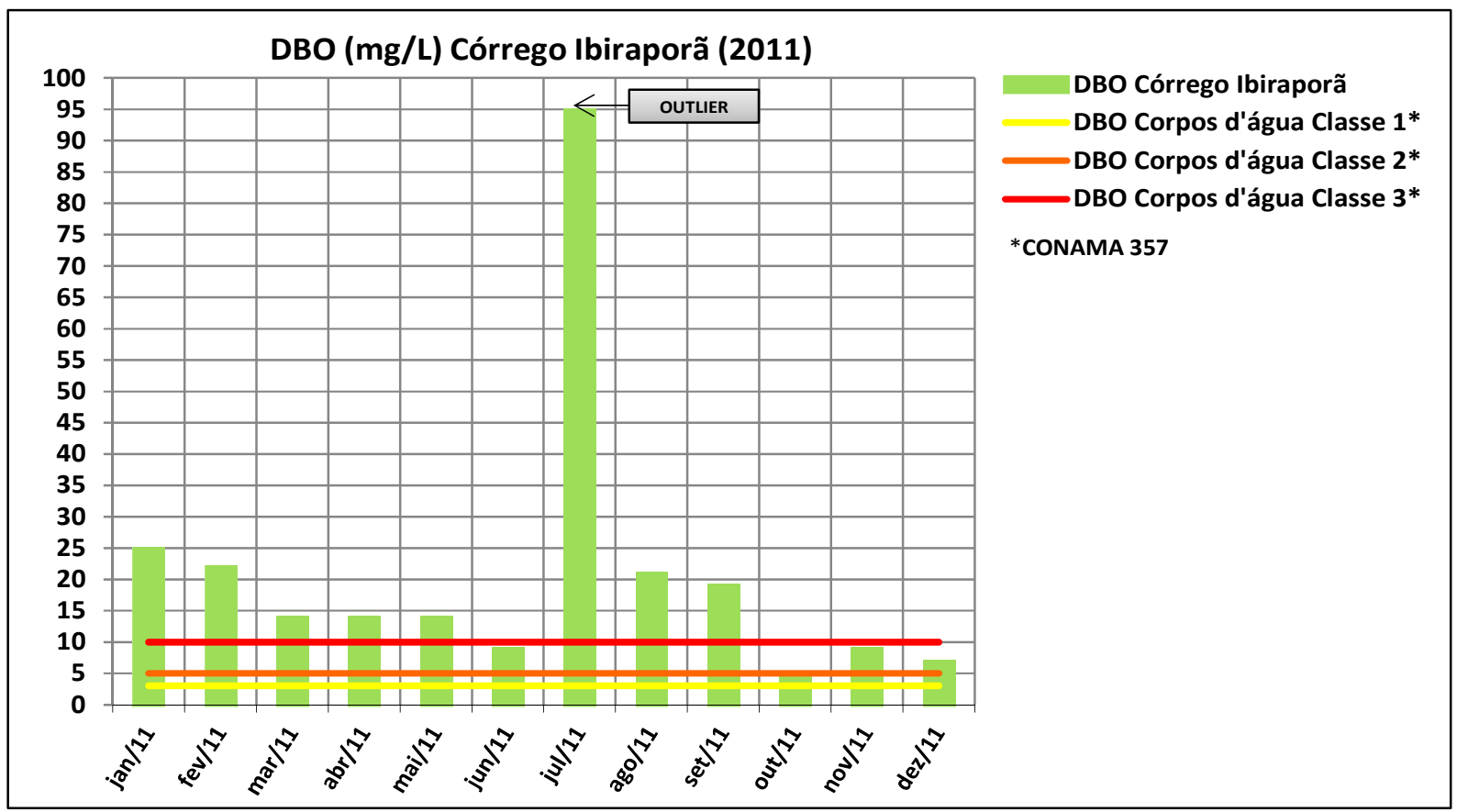

Ilustração 50 - DBO do Córrego Ibiraporã em 2011. Fonte: Elaborado pela autora a partir de Córrego Limpo (s/d) e CONAMA 357 (2005). 


\subsection{VARIÁVEIS FÍSICAS E QUÍMICAS}

\subsubsection{Metodologia}

Foram realizadas analises referentes às variáveis físicas e químicas para avaliação da qualidade da água dos dois córregos em estudo. Na Nascente do Sapé foram realizadas coletas em três pontos do canal (Estacas 31, 28 e 25), no final do período chuvoso, em 14/03/2013, para avaliação da qualidade da água, tais amostras foram analisadas no laboratório de saneamento da escola politécnica. A Ilustração 51, a seguir, mostra os três pontos onde foram realizadas as coletas na Nascente do Sapé.

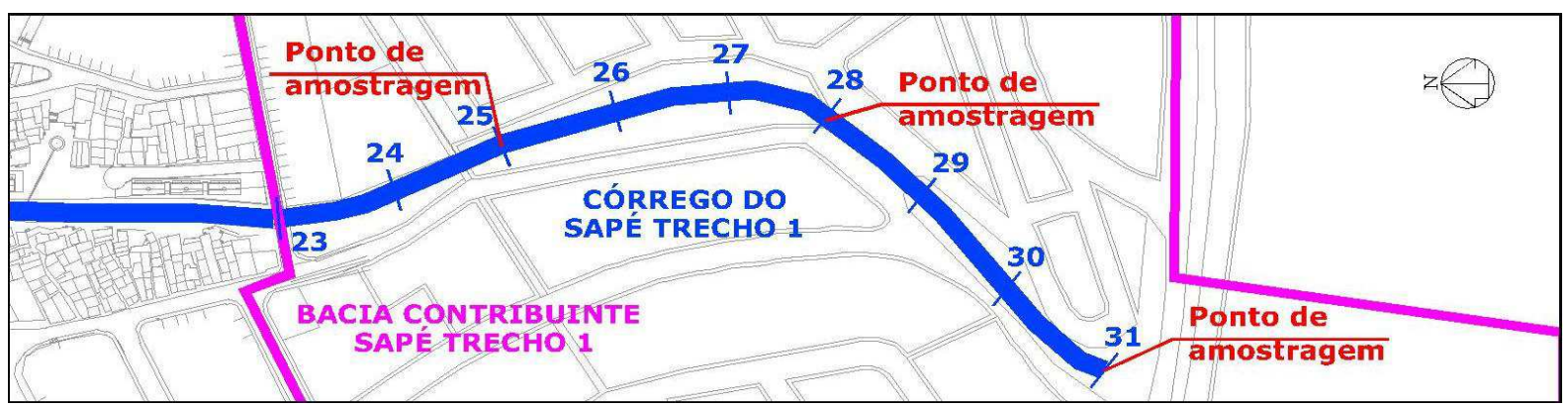

Ilustração 51 - Nascente do Sapé: Pontos de coleta para avaliação física e química da qualidade da água. Fonte: Elaborado pela autora.

Já no Córrego lbiraporã foram realizadas duas coletas, uma no período seco e outra no período chuvoso, para comparação dos resultados obtidos nos dois períodos e identificação de padrões decorrentes da influência da carga difusa. A primeira coleta foi realizada em 11/09/2012 (Período seco) e a segunda em 30/01/2013 (Período chuvoso) e em dois pontos do canal, próximo à estaca 9 e à estaca 16 como mostrado na llustração 52 , a seguir.

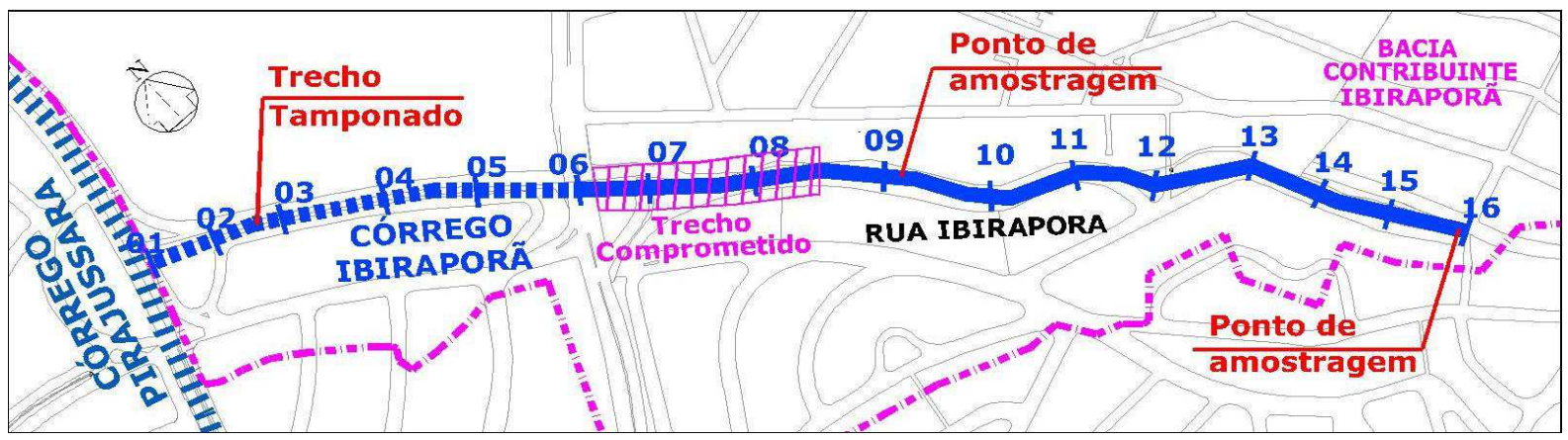

Ilustração 52 - Córrego Ibiraporã: Pontos de coleta para avaliação física e química da qualidade da água. Fonte: Elaborado pela autora. 
As análises das amostras coletadas no Córrego Ibiraporã foram realizadas pelo laboratório "Operator Meio Ambiente". Os laudos emitidos pelo laboratório, apresentados no Item 7 denominado Anexos, foram utilizados para embasamento dos estudos apresentados nos itens seguintes. A llustração 53 mostra o material utilizado nas coletas pelo laboratório "Operator Meio Ambiente".

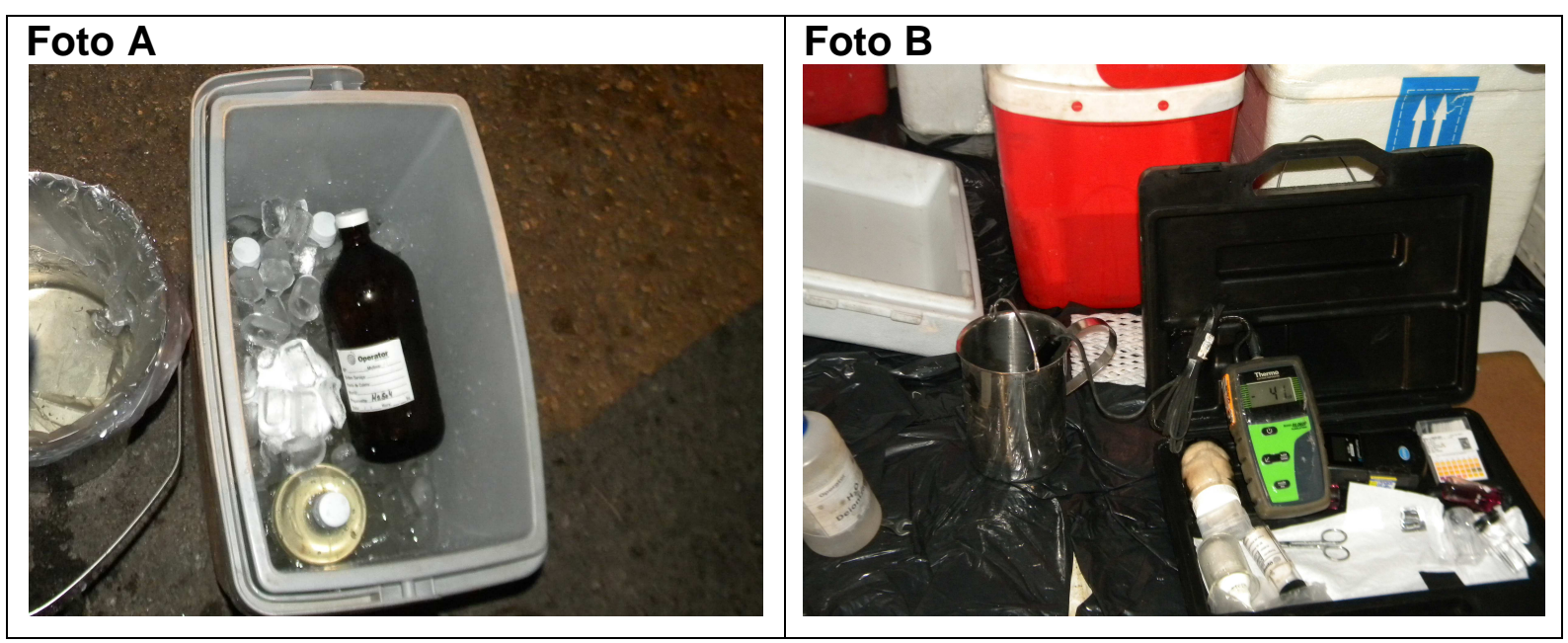

Ilustração 53 - Córrego Ibiraporã: Coleta de amostras de água para análises físicas de químicas. Fonte: Fotos da autora.

\subsubsection{Teste de Friedman}

Quando uma série de dados não segue uma distribuição que obedece aos critérios para aplicação de uma análise paramétrica, pode-se aplicar ao conjunto de dados um analise não paramétrica. No caso dos valores obtidos para as variáveis físicas e químicas temos uma série de dados que pode ser analisada pela análise não paramétrica e para tanto foi utilizado o Teste de Friedman. Este teste, que é indicado para casos que contenham 3 ou mais grupos amostrais, consiste em ordenar os grupos amostrais em postos, realizar a verificação da igualdade da soma dos postos de cada grupo e por fim realiza-se o cálculo da estatística de teste de Friedman, dada pela Equação 3 apresentada a seguir (POCINHO, 2010).

$$
\mathrm{X}^{2}=\frac{12}{b \cdot k \cdot(k+1)} \sum_{i=1}^{k} R_{i}^{2}-3 \cdot b \cdot(k+1)
$$

(Equação 3 - POCINHO, 2010)

Onde: $b$ = número de blocos (neste caso o número de variáveis analisadas), $k=$ número de tratamentos e $\mathrm{R}=$ somatória dos postos. 


\subsubsection{Resultados e discussões}

\subsubsection{Variáveis físicas e químicas: Nascente do Sapé}

Os resultados obtidos para as análises realizadas nas amostras da Nascente do Sapé coletadas nas estacas 31, 28 e 25 (llustração 51) são apresentados na Tabela 17, a seguir.

Tabela 17 - Nascente do Sapé: Variáveis físicas e químicas da água - Período chuvoso. Fonte: Elaborado pela autora.

\begin{tabular}{|l|c|c|c|}
\hline \multicolumn{4}{|l|}{ Nascente do Sapé: Variáveis Fisícas e Químicas da Água (14/03/2012) } \\
\hline Variável / Ponto & Estaca 31 & Estaca 28 & Estaca 25 \\
\hline pH & 6,90 & 6,60 & 6,80 \\
\hline Alcalinidade (mg/L) & 700,00 & 600,00 & 590,00 \\
\hline N amoniacal (mg/L) & 25,76 & 14,00 & 11,20 \\
\hline Nitrato (mg/L) & 0,15 & 0,03 & 0,13 \\
\hline NKT (mg/L) & 29,12 & 11,20 & 9,52 \\
\hline Turbidez (UNT) & 33,70 & 15,80 & 26,10 \\
\hline Temperatura ( ${ }^{\circ}$ C) & 20,90 & 21,00 & 20,70 \\
\hline OD (mg/L) & 7,38 & 7,17 & 6,99 \\
\hline DBO (mg/L) & 43,00 & 25,00 & 35,00 \\
\hline DQO (mg/L) & 64,80 & 51,60 & 54,80 \\
\hline Fósforo total (mg/L) & 0,70 & 0,20 & 0,20 \\
\hline
\end{tabular}

Comparando os pontos monitorados (llustração 51) podemos observar que a DBO do corpo d'água encontra-se acima do esperado para um corpo d'água livre de cargas pontuais. Observa-se a DBO e o fósforo total mais acentuado na Estaca 31 que corresponde ao ponto inicial do canal, este ponto possui declividade reduzida o que gera um acumulo de água no local, portanto cria-se um ponto de retenção também de matéria orgânica, o que em parte explica estes valores acentuados. $O$ segundo ponto, Estaca 28, corresponde a um trecho com maior velocidade e possivelmente devido a isso a qualidade deste ponto é ligeiramente melhor que a dos demais pontos. Já o terceiro ponto, Estaca 25, está sobre maior influência dos lançamentos cumulativos de cargas pontuais ainda existentes e também das cargas difusas se comparado ao ponto 2 e portanto apresenta qualidade pior do que este ponto. Além da avaliação qualitativa, pode-se ainda realizar uma análise estatística na série de dados para obter o grau de diferença entre os grupos amostrais. Por tratar-se de um conjunto de dados que não obedece aos critérios para uma análise 
parametrizada, deve utilizar uma análise não paramétrica e neste caso a que melhor se enquadra é a obtida através do Teste de Friedman, como já descrito na sessão anterior. Os resultados obtidos com a aplicação deste teste são apresentados no item seguinte.

\subsection{Teste de Friedman: Nascente do Sapé}

Para aplicação do Teste de Friedman aos dados obtidos para a Nascente do Sapé considerou-se as variáveis físicas e químicas que apresentavam alterações quantitativas, ou seja, aquelas que poderiam expressar mudanças qualitativas. A Tabela 18 apresenta os postos obtidos para as variáveis consideradas nesta análise, sendo o $\mathrm{P} 1$ relativo à coleta na Estaca $31, \mathrm{o} P 2$ à estaca 28 e $\mathrm{P} 3$ relativo à estaca 25 (llustração 51). Já a Tabela 19 apresenta o resultado obtido com a aplicação do Teste.

Tabela 18 - Postos obtidos para as variáveis físicas e químicas - Nascente do Sapé. Fonte: Elaborado pela autora.

\begin{tabular}{|l|c|c|c|c|c|c|}
\hline \multicolumn{6}{|c|}{ Postos obtidos para as Variáveis Físicas e Químicas da Água - Nascente do Sapé } \\
\hline Variáveis & P1 & P1: Postos & P2 & $\begin{array}{c}\text { P2: } \\
\text { Postos }\end{array}$ & P3 & $\begin{array}{c}\text { P3: } \\
\text { Postos }\end{array}$ \\
\hline pH & 6,900 & 3 & 6,600 & 1 & 6,800 & 2 \\
\hline Alcalinidade (mg/L) & 700,000 & 3 & 600,000 & 2 & 590,000 & 1 \\
\hline N amoniacal (mg/L) & 25,760 & 3 & 14,000 & 2 & 11,200 & 1 \\
\hline Nitrato (mg/L) & 0,147 & 3 & 0,027 & 1 & 0,132 & 2 \\
\hline NKT (mg/L) & 29,120 & 3 & 11,200 & 2 & 9,520 & 1 \\
\hline Turbidez (UNT) & 33,700 & 3 & 15,800 & 1 & 26,100 & 2 \\
\hline Temperatura (') & 20,900 & 2 & 21,000 & 3 & 20,700 & 1 \\
\hline OD (mg/L) & 7,380 & 3 & 7,170 & 2 & 6,990 & 1 \\
\hline DBO (mg/L) & 43,000 & 3 & 25,000 & 1 & 35,000 & 2 \\
\hline DQO (mg/L) & 64,80 & 3 & 51,60 & 1 & 54,80 & 2 \\
\hline Fósforo total (mg/L) & 0,70 & 3 & 0,21 & 1,5 & 0,20 & 1,5 \\
\hline R & & 32,0 & & 17,5 & & 16,5 \\
\hline
\end{tabular}

Tabela 19 - Teste de Friedman - Nascente do Sapé. Fonte: Elaborado pela autora.

\begin{tabular}{|c|c|}
\hline \multicolumn{2}{|c|}{ Teste de Friedman } \\
\hline $\mathbf{x}^{2}$ & 13,6818 \\
\hline
\end{tabular}

Para um nível de significância $\alpha=5 \%$ e grau de liberdade igual a 2, o valor crítico da distribuição $X^{2}$ obtido é 5,991 (GUIMARÃES, 2008); como o valor obtido com o cálculo do Teste de Friedman foi 13,6818 rejeita-se a hipótese nula. Ou seja, há diferença significativa entre os valores obtidos e o esperado se as amostras 
fossem iguais. No entanto, cabe realizar ainda uma segunda análise, uma vez que os valores $R$ obtidos podem ainda serem interpretados relacionando a qualidade da água no ponto, uma vez que os postos foram ordenados no sentido crescente da influência negativa da variável analisada, por exemplo, quanto mais oxigênio dissolvido na água melhor a saúde do corpo d'água (Considerando um corpo d'água característico da mata atlântica, como é o caso do corpo d'água em questão na sua condição natural), portanto a maior taxa de oxigênio recebeu o posto 4 e a menor o posto 1. O mesmo foi feito para as demais variáveis. Concluímos então que quanto maior o valor de $\mathrm{R}$ obtido, pior o estado do corpo d'água.

Partindo destas premissas, é possível analisar detalhadamente os resultados obtidos. Os valores "R" obtidos para os três pontos analisados é condizente com a avaliação qualitativa, ou seja, a nascente $(R=32,0)$ apresenta qualidade pior que os demais pontos, possivelmente pelos motivos já expostos. Já no que se refere ao ponto 2 e 3 , os valores "R" obtidos (Ponto 2, $R=17,5$ e ponto $3, R=16,5$ ) foram próximos, mostrando que a qualidade da água nos dois pontos é semelhante.

\subsubsection{Variáveis físicas e químicas: Córrego lbiraporã}

Os resultados obtidos para as análises realizadas nas amostras do Córrego Ibiraporã são apresentados na Tabela 20, a seguir, sendo P1TS relativo à coleta na estaca 16 no período seco, P2TS à estaca 9 no período seco, P1TC à estaca 16 no período chuvoso e P2TC à estaca 9 no período chuvoso (Ilustração 52).

Tabela 20 - Córrego Ibiraporã: Monitoramento das variáveis físicas e químicas da água. Fonte: Elaborado pela autora.

\begin{tabular}{|l|c|c|c|c|}
\hline \multicolumn{5}{|c|}{ Monitoramento das Variáveis Físicas e Químicas da Água } \\
\hline Variáveis & P1TS & P2TS & P1TC & P2TC \\
\hline DBO (mg/L) & 4,000 & 5,000 & 15,000 & 9,000 \\
\hline DQO (mg/L) & 27,000 & 22,000 & 38,000 & 22,000 \\
\hline OD (mg/L) & 5,190 & 2,320 & 4,800 & 3,900 \\
\hline Temperatura ${ }^{\circ} \mathbf{C}$ & 21,900 & 22,700 & 23,100 & 24,400 \\
\hline Turbidez & 1,540 & 1,070 & 9,430 & 10,800 \\
\hline pH & 7,420 & 7,570 & 7,300 & 7,470 \\
\hline Alcalinidade Total (mg/L) & 67,000 & 87,000 & 56,000 & 72,000 \\
\hline Sólidos Dis. Totais (mg/L) & 209,000 & 218,000 & 43,000 & 214,000 \\
\hline Óleos e Graxas (mg/L) & $<5$ & $<5$ & 11,000 & 8,000 \\
\hline Fósforo Total (mg/L) & 0,178 & 0,324 & $<3,6000$ & $<3,6000$ \\
\hline Itrio (\%) & 90,00 & 87,00 & 76,30 & 81,80 \\
\hline
\end{tabular}


Tabela 20 - Córrego Ibiraporã: Monitoramento das variáveis físicas e químicas da água. Fonte: Elaborado pela autora. (Continuação)

\begin{tabular}{|c|c|c|c|c|}
\hline \multicolumn{5}{|c|}{ Série de Nitrogênio } \\
\hline Variáveis & P1TS & P2TS & P1TC & P2TC \\
\hline Nitrato (mg/L) & 5,810 & 0,780 & 1,780 & 1,750 \\
\hline Nitrogênio Amoniacal (mg/L) & 4,270 & 7,290 & $<0,08$ & 1,420 \\
\hline Nitrogênio Kjedahl Total (mg/L) & 4,950 & 8,460 & - & - \\
\hline \multicolumn{5}{|c|}{ Série de Cloro } \\
\hline Variáveis & P1TS & P2TS & P1TC & P2TC \\
\hline 2-Clorofenol (mg/L) & $<0,010$ & $<2,00$ & $<0,010$ & $<0,010$ \\
\hline 1,2-Dicloroetano (mg/L) & $<2,00$ & $<2,00$ & $<2,00$ & $<2,00$ \\
\hline 1,1-Dicloroeteno (mg/L) & $<2,00$ & $<0,010$ & $<2,00$ & $<2,00$ \\
\hline Diclorometano $(\mu \mathrm{g} / \mathrm{L})$ & $<2,00$ & $<2,00$ & $<2,00$ & $<2,00$ \\
\hline Tetracloreto de Carbono ( $\mu \mathrm{g} / \mathrm{L})$ & $<1,00$ & $<1,00$ & $<2,00$ & $<2,00$ \\
\hline Tetracloroeteno $(\mu \mathrm{g} / \mathrm{L})$ & $<2,00$ & $<2,00$ & $<2,00$ & $<2,00$ \\
\hline Triclorobenzenos ( $\mu \mathrm{g} / \mathrm{L}$ ) & $<0,07$ & $<0,07$ & $<2,00$ & $<2,00$ \\
\hline Tricloroeteno $(\mu \mathrm{g} / \mathrm{L})$ & $<0,10$ & $<0,10$ & $<2,00$ & $<2,00$ \\
\hline \multicolumn{5}{|c|}{ Série de Derivados de Petróleo } \\
\hline Variáveis & P1TS & P2TS & P1TC & P2TC \\
\hline Benzeno ( $\mu \mathrm{g} / \mathrm{L}$ ) & $<2,00$ & $<2,00$ & $<2,00$ & $<2,00$ \\
\hline Etilbenzeno $(\mu \mathrm{g} / \mathrm{L})$ & $<2,00$ & $<2,00$ & $<2,00$ & $<2,00$ \\
\hline Tolueno $(\mu \mathrm{g} / \mathrm{L})$ & $<2,00$ & $<2,00$ & $<2,00$ & $<2,00$ \\
\hline Estireno $(\mu \mathrm{g} / \mathrm{L})$ & $<2,00$ & $<2,00$ & $<2,00$ & $<2,00$ \\
\hline Xilenos ( $\mu \mathrm{g} / \mathrm{L})$ & $<2,00$ & $<2,00$ & $<2,00$ & $<2,00$ \\
\hline p-Bromofluorbenzeno (\%) & 90,52 & 104,41 & 109,73 & 111,52 \\
\hline Tolueno-d8 (\%) & 83,31 & 89,83 & 105,21 & 88,60 \\
\hline 2-Fluorobifenil (\%) & 87,13 & 102,56 & 79,00 & 77,87 \\
\hline p-Terfenil d14 (\%) & 99,69 & 89,99 & 78,78 & 92,73 \\
\hline \multicolumn{5}{|c|}{ Série de Metais } \\
\hline Variáveis & P1TS & P2TS & P1TC & P2TC \\
\hline Alumínio Dissolvido (mg/L) & 0,098 & 0,194 & 0,027 & 0,015 \\
\hline Cobre Dissolvido (mg/L) & 0,011 & 0,003 & $<0,0017$ & 0,002 \\
\hline Ferro Dissolvido (mg/L) & 0,092 & 0,704 & 0,206 & 0,126 \\
\hline Mercúrio Total (mg/L) & $<0,00010$ & $<0,00010$ & $<0,00010$ & $<0,00010$ \\
\hline Antimônio (mg/L) & 0,004 & $<0,0020$ & $<0,002$ & $<0,002$ \\
\hline Arsênio Total (mg/L) & $<0,0020$ & $<0,0020$ & $<0,002$ & $<0,002$ \\
\hline Bário Total (mg/L) & 0,066 & 0,087 & 0,063 & 0,081 \\
\hline Berílio Total $(\mathrm{mg} / \mathrm{L})$ & $<0,0060$ & $<0,0060$ & $<0,006$ & $<0,006$ \\
\hline Boro Total (mg/L) & 0,054 & $<0,0520$ & $<0,052$ & $<0,052$ \\
\hline Cádmio Total (mg/L) & $<0,0017$ & $<0,0017$ & $<0,0017$ & $<0,0017$ \\
\hline Chumbo Total (mg/L) & $<0,0020$ & $<0,0020$ & 0,006 & 0,003 \\
\hline Cobalto Total (mg/L) & $<0,0020$ & $<0,0020$ & 0,016 & $<0,002$ \\
\hline Cromo Total (mg/L) & 0,007 & $<0,0060$ & $<0,006$ & $<0,006$ \\
\hline Lítio Total (mg/L) & $<0,0270$ & $<0,0270$ & $<0,027$ & $<0,027$ \\
\hline Manganês Total (mg/L) & 0,424 & 0,303 & 0,254 & 0,145 \\
\hline Níquel Total (mg/L) & $<0,0017$ & 0,003 & $<0,0017$ & $<0,0017$ \\
\hline Prata Total (mg/L) & $<0,0001$ & 0,004 & $<0,00010$ & $<0,00010$ \\
\hline Selênio Total (mg/L) & 0,005 & 0,004 & $<0,003$ & $<0,003$ \\
\hline Vanádio Total (mg/L) & $<0,0040$ & $<0,0040$ & $<0,004$ & $<0,004$ \\
\hline Zinco Total (mg/L) & 0,013 & 0,058 & 0,034 & 0,018 \\
\hline Metais Totais (mg/L) & 0,774 & 1,360 & 0,606 & 0,389 \\
\hline
\end{tabular}


Através da análise qualitativa dos dados podemos concluir que há um aumento significativo na concentração de poluentes no corpo d'água durante 0 inverno devido à ausência do fenômeno da diluição que ocorre no verão, resultado do aumento da precipitação sobre a bacia e consequente aumento da vazão do corpo d'água. Vemos também aparecer no verão o aumento de variáveis características do componente carga difusa, como óleos e graxa, alguns metais como Chumbo e compostos derivados de Petróleo. Para este caso, assim como o da Nascente do Sapé, além da avaliação qualitativa, pode-se ainda realizar uma análise estatística na série de dados para obter o grau de diferença entre os grupos amostrais. Por tratar-se também de um conjunto de dados que não obedece aos critérios para uma análise parametrizada, deve utilizar uma análise não paramétrica através do Teste de Friedman. Os resultados obtidos com a aplicação deste teste são apresentados no item seguinte.

\subsection{Teste de Friedman: Córrego Ibiraporã}

No caso do Córrego Ibiraporã, para aplicação do Teste de Friedman considerou-se também as variáveis físicas e químicas que apresentavam alterações quantitativas, ou seja, aquelas que poderiam expressar mudanças qualitativas. A Tabela 21 apresenta os postos obtidos e a Tabela 22 o resultado obtido para o teste.

Tabela 21 - Postos obtidos para as variáveis físicas e químicas da água- Córrego Ibiraporã. Fonte: Elaborado pela autora.

\begin{tabular}{|c|c|c|c|c|c|c|c|c|}
\hline \multicolumn{9}{|c|}{ Postos obtidos para as Variáveis Físicas e Químicas da Água - Córrego lbiraporã } \\
\hline Variáveis & P1TS & $\begin{array}{c}\text { P1TS: } \\
\text { Postos }\end{array}$ & P2TS & $\begin{array}{l}\text { P2TS: } \\
\text { Postos }\end{array}$ & P1TC & $\begin{array}{l}\text { P1TC: } \\
\text { Postos }\end{array}$ & P2TC & $\begin{array}{l}\text { P2TC: } \\
\text { Postos }\end{array}$ \\
\hline DBO (mg/L) & 4,000 & 1 & 5,000 & 2 & 15,000 & 4 & 9,000 & 3 \\
\hline DQO (mg/L) & 27,000 & 3 & 22,000 & 1,5 & 38,000 & 4 & 22,000 & 1,5 \\
\hline$O D(\mathrm{mg} / \mathrm{L})$ & 5,190 & 1 & 2,320 & 4 & 4,800 & 2 & 3,900 & 3 \\
\hline Temperatura ${ }^{\circ} \mathrm{C}$ & 21,900 & 1 & 22,700 & 2 & 23,100 & 3 & 24,400 & 4 \\
\hline Turbidez & 1,540 & 2 & 1,070 & 1 & 9,430 & 3 & 10,800 & 4 \\
\hline pH & 7,420 & 2 & 7,570 & 4 & 7,300 & 1 & 7,470 & 3 \\
\hline Alcalinidade Total $(\mathrm{mg} / \mathrm{L})$ & 67,000 & 2 & 87,000 & 4 & 56,000 & 1 & 72,000 & 3 \\
\hline Sólidos Dis. Totais (mg/L) & 209,000 & 2 & 218,000 & 4 & 43,000 & 1 & 214,000 & 3 \\
\hline Óleos e Graxas (mg/L) & $<5$ & 1,5 & $<5$ & 1,5 & 11,000 & 4 & 8,000 & 3 \\
\hline Itrio (\%) & 90,00 & 4 & 87,00 & 3 & 76,30 & 1 & 81,80 & 2 \\
\hline p-Bromofluorbenzeno (\%) & 90,52 & 1 & 104,41 & 2 & 109,73 & 3 & 111,52 & 4 \\
\hline Tolueno-d8 (\%) & 83,31 & 1 & 89,83 & 3 & 105,21 & 4 & 88,60 & 2 \\
\hline 2-Fluorobifenil (\%) & 87,13 & 3 & 102,56 & 4 & 79,00 & 2 & 77,87 & 1 \\
\hline p-Terfenil d14 (\%) & 99,69 & 4 & 89,99 & 2 & 78,78 & 1 & 92,73 & 3 \\
\hline Nitrato (mg/L) & 5,810 & 4 & 0,780 & 1 & 1,780 & 3 & 1,750 & 2 \\
\hline Metais Totais (mg/L) & 0,774 & 3 & 1,360 & 4 & 0,606 & 2 & 0,389 & 1 \\
\hline $\mathbf{R}$ & & 35,5 & & 43,0 & & 39,0 & & 42,5 \\
\hline
\end{tabular}


Tabela 22 - Teste de Friedman - Córrego Ibiraporã. Fonte: Elaborado pela autora.

\begin{tabular}{|c|c|}
\hline \multicolumn{2}{|c|}{ Teste de Friedman } \\
\hline $\mathbf{X}^{2}$ & 1,3687 \\
\hline
\end{tabular}

Para um nível de significância $\alpha=5 \%$ e grau de liberdade igual a 3, o valor crítico da distribuição $X^{2}$ obtido é 7,815 (GUIMARÃES, 2008); como o valor obtido com o cálculo do Teste de Friedman foi 1,3687 não podemos rejeitar a hipótese nula. Ou seja, não há diferença significativa entre os valores obtidos e o esperado se as amostras fossem iguais. No entanto, cabe neste caso também realizar uma segunda análise, com base nos valores de "R" obtidos, partindo das mesmas premissas adotadas para o caso da Nascente do Sapé, ou seja, quanto maior o valor de $\mathrm{R}$ obtido, pior o estado do corpo d'água. Partindo destas premissas, é possível analisar detalhadamente os resultados obtidos.

O ponto 1 trata-se da nascente do canal, portanto no inverno como há menos diluição da carga contida no canal, o valor $R$ obtido no inverno $(R=35,5)$ foi menor do que o valor obtido no verão $(R=39,0)$ quando o canal apresenta uma maior diluição de sua carga devido ao regime de chuvas; podemos associar a isto o fato da nascente estar sobre menor influência de cargas pontuais e difusas, uma vez que trata-se do trecho inicial do canal. Já o ponto 2 , mais à jusante apresentou valores $\mathrm{R}$ muito parecidos para os dois períodos (Inverno, $R=43,0$ e verão, $R=42,5$ ) o que podemos interpretar como sendo resultado da carga difusa trazida pelo escoamento superficial, pois do contrário o corpo d'água deveria apresentar uma melhoria na qualidade de suas águas no verão devido ao efeito da diluição dos poluentes pelas chuvas constantes. Portanto, se por um lado o fator diluição é adicionado ao processo, por outro se adiciona também o fator carga difusa, desta forma tem-se a qualidade global do corpo d'água constante nos dois períodos. 


\subsection{UNIDADE DE CARGA (UC)}

\subsubsection{Metodologia}

O método da Unidade de Carga consiste em aplicar índices de geração de carga difusa para diferentes tipos de uso de solo existentes na bacia em estudo. $O$ método não faz correlação com a hidrologia e a morfologia da bacia, mas tem como vantagem ser de fácil aplicação e apresentar resultados eficientes, podendo ser aplicado em bacias com diferentes tipos de uso do solo (NOVOTNY, 2003).

Para obter a geração média de carga difusa para cada classe de uso do solo, a fim de calibrar o modelo e obter a geração total de carga difusa para cada bacia, foi elaborado um método que relaciona os valores de produção de carga difusa para cada tipo de uso do solo do Corine Land Cover (CLC) e a produção de carga difusa para o tecido urbano continuo monitorada por Steinke (2007). A sequência de tabelas a seguir apresenta os valores utilizados. A Tabela 23 apresenta os valores de contribuição por tipo de uso do solo elaborado pelo Corine Land Cover (CLC) que possui uma variação de 0 a 10. A Tabela 24 apresenta os valores calculados por Steinke (2007), com base no sistema MQUAL, para produção de carga difusa para tecido Urbano. Desta forma, com base nas proporções obtidas pelo Corine Land Cover (CLC) e no valor fornecido por Steinke (2007) foi produzida a Tabela 25, que será usada como referência para o cálculo da produção de carga difusa nas bacias em estudo. O método da Unidade de Carga foi empregado neste estudo para calcular a geração de carga difusa nas bacias da Nascente do Sapé e do Córrego Ibiraporã e os resultados obtidos são apresentados no item seguinte.

Tabela 23 - Produção de carga difusa para classes de uso do solo do Corine Land Cover (CLC). Fonte: Adaptado de Cecchi et al. (2007).

\begin{tabular}{|c|c|c|}
\hline \multicolumn{3}{|l|}{ Classes de Uso de Solo do CLC } \\
\hline \multicolumn{2}{|l|}{ 1. Tecidos Artificializados } & $(0-10)$ \\
\hline \multirow[t]{2}{*}{ 1.1. Tecido Urbano } & 1.1.1. Tecido Urbano Contínuo & 8,22 \\
\hline & 1.1.2. Tecido Urbano Descontínuo & 6,89 \\
\hline \multirow{2}{*}{$\begin{array}{l}\text { 1.2. Indústria, Comércio e } \\
\text { Transporte }\end{array}$} & 1.2.1. Indústria, Comércio e Equipamentos Gerais & 7,78 \\
\hline & 1.2.2. Redes Viárias e Ferroviárias e espaços associados & 5,67 \\
\hline \multirow[t]{2}{*}{ 1.3. Zonas Verdes Orientadas } & 1.3.1. Espaços Verdes Urbanos & 2,33 \\
\hline & 1.3.2. Equipamentos desportivos e de lazer & 3,00 \\
\hline
\end{tabular}


Tabela 24 - Produção de carga difusa para tecido urbano. Fonte: Adaptado de Steinke (2007).

\begin{tabular}{|l|c|c|c|c|}
\hline Produção de Carga Difusa (Kg/Km $/ \mathrm{dia})$ & N total & P total & Ss Total & TOTAL \\
\hline Tipo de cobertura & 1,274 & 0,034 & 50,000 & 51,308 \\
\hline Tecido Urbano Contínuo &
\end{tabular}

Tabela 25 - Produção de Poluição Difusa para classes de uso do solo. Fonte: Elaborado pela autora.

\begin{tabular}{|c|c|c|c|c|c|}
\hline \multicolumn{6}{|c|}{ Produção de Carga Difusa por Tipo de Uso do Solo ( $\left.\mathrm{Kg} / \mathrm{Km}^{2} / \mathrm{dia}\right)$} \\
\hline \multicolumn{2}{|c|}{ 1. Tecidos Artificializados } & $\mathrm{N}$ total & P total & Ss Total & TOTAL \\
\hline \multirow[t]{2}{*}{ 1.1. Tecido Urbano } & 1.1.1. Tecido Urbano Contínuo & 1,274 & 0,034 & 50,000 & 51,308 \\
\hline & 1.1.2. Tecido Urbano Descontínuo & 1,068 & 0,028 & 41,910 & 43,006 \\
\hline \multirow{2}{*}{$\begin{array}{l}\text { 1.2. Indústria, Comércio } \\
\text { e Transporte }\end{array}$} & 1.2.1. Indústria, Comércio e Equipamentos Gerais & 1,206 & 0,032 & 47,324 & 48,562 \\
\hline & 1.2.2. Redes Viárias, Ferroviárias e espaços associados & 0,879 & 0,023 & 34,489 & 35,391 \\
\hline \multirow{2}{*}{$\begin{array}{l}\text { 1.3. Zonas Verdes } \\
\text { Orientadas }\end{array}$} & 1.3.1. Espaços Verdes Urbanos & 0,361 & 0,010 & 14,173 & 14,544 \\
\hline & 1.3.2. Equipamentos desportivos e de lazer & 0,465 & 0,012 & 18,248 & 18,726 \\
\hline
\end{tabular}

\subsubsection{Resultados e Discussões}

\subsubsection{Unidade de carga (UC): Córrego Ibiraporã e Nascente do Sapé}

Através de imagens aerofotogramétricas e de visitas às áreas de estudo, foi possível elaborar o mapa com a classe de uso do solo para a bacia da Nascente do Sapé e para a bacia do Córrego lbiraporã. A llustração 54 e a llustração 55 mostram a divisão de classes de uso para as áreas de estudo.

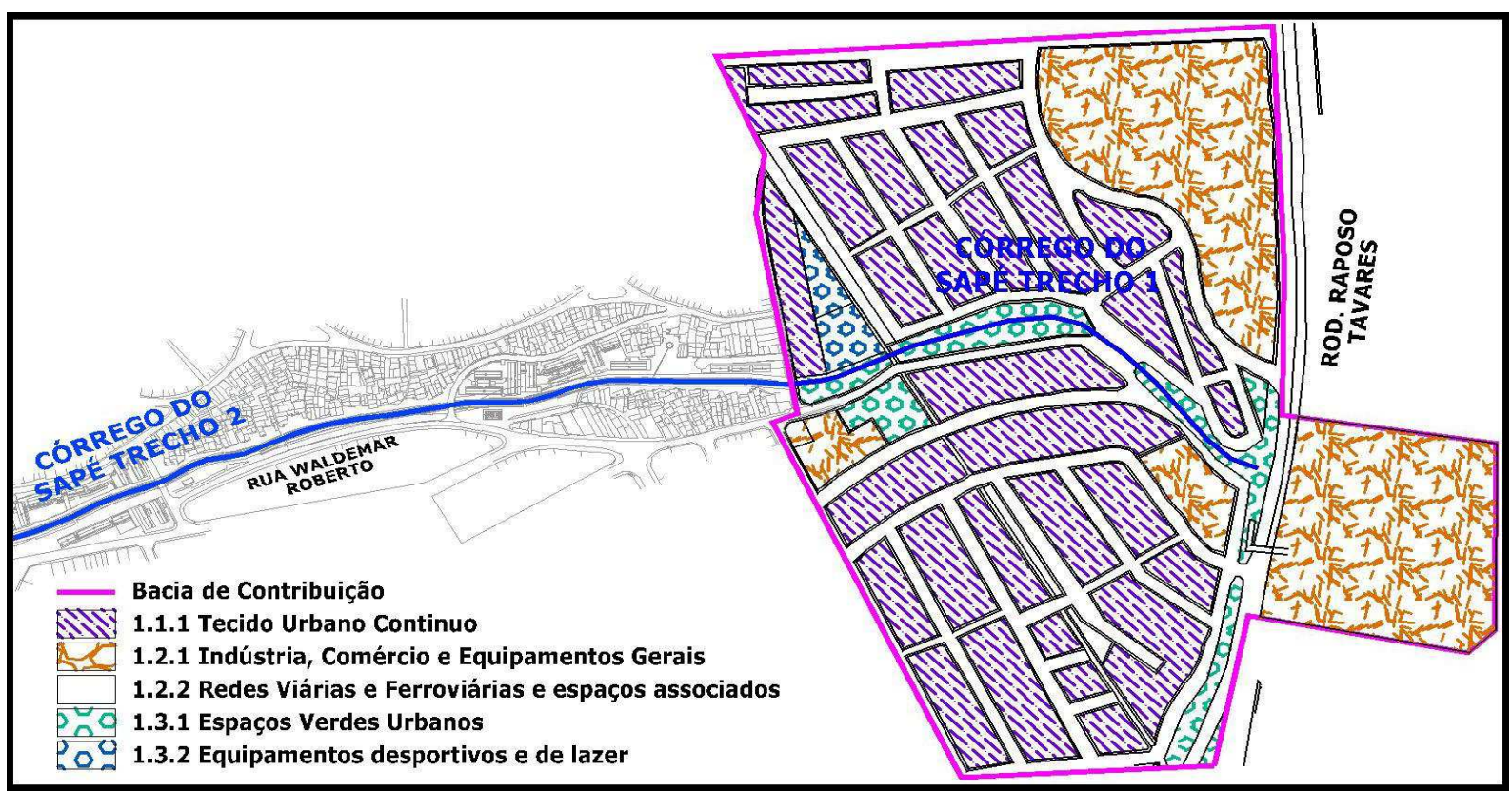

Ilustração 54 - Distribuição na bacia da Nascente do Sapé das classes de uso do solo do Corine Land Cover (CLC). Fonte: Elaborado pela autora. 


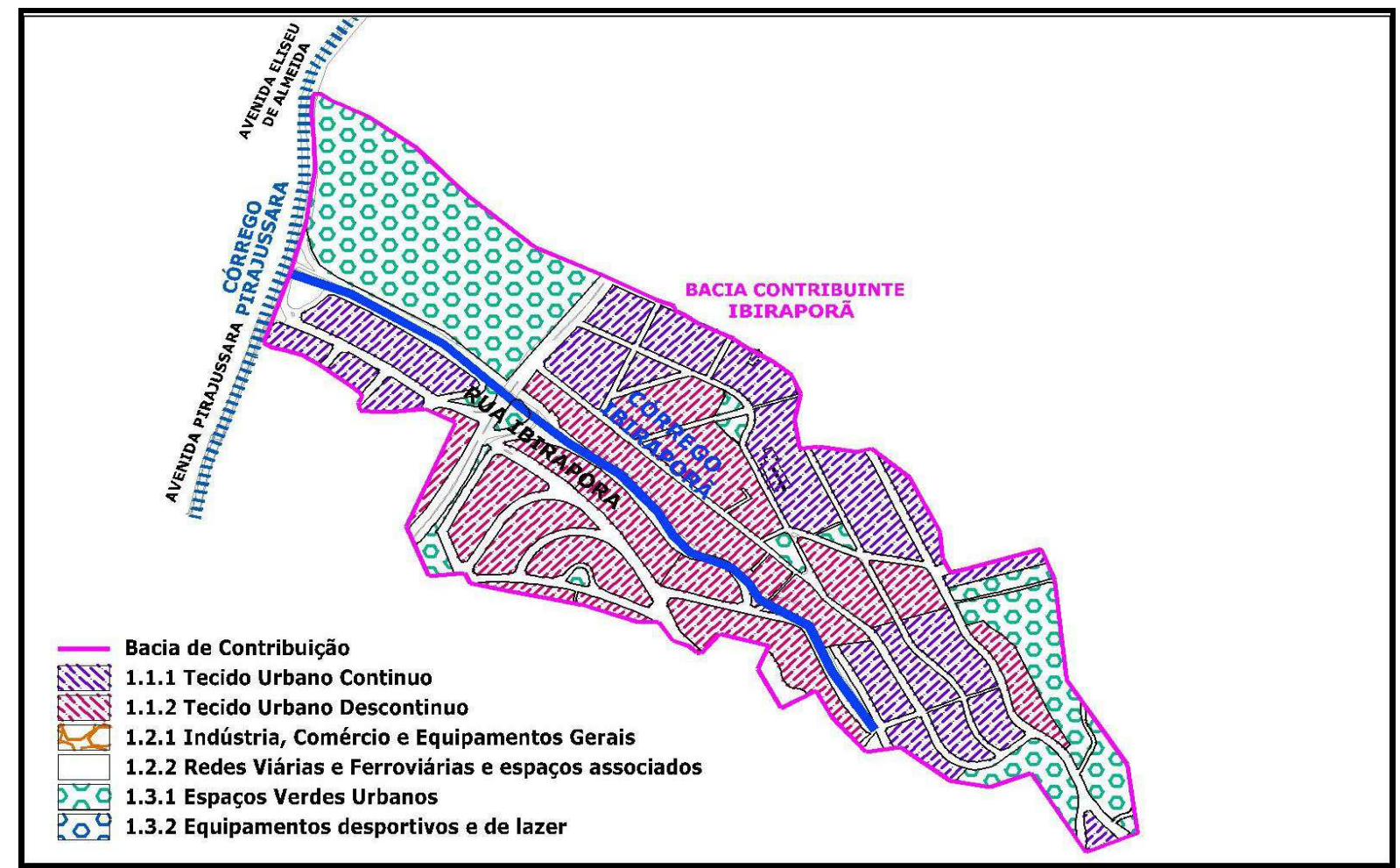

Ilustração 55 - Distribuição na bacia do Córrego lbiraporã das classes de uso do solo do Corine Land Cover (CLC). Fonte: Elaborado pela autora.

Através da caracterização das bacias se podem notar as grandes diferenças entre elas, que além de possuírem tamanhos distintos, possuem ocupações também diferentes. Enquanto a bacia do Córrego Ibiraporã possui em sua bacia uma ocupação pouco adensada caracterizada por moradias de médio e alto padrão, com uma grande porção de espaços verdes e trafego viário doméstico, a bacia da Nascente do Sapé possui uma ocupação residencial mais adensada, como moradias de baixo e médio padrão, espaços verdes restritos e trafego viário intenso, devido à proximidade com a Rodovia Raposo Tavares.

Utilizando a metodologia descrita no item anterior foi possível estimar a produção de carga difusa nas duas bacias e os resultados obtidos são apresentados na Tabela 26 e na Tabela 27. 
Tabela 26 - Produção de carga difusa para as diferentes parcelas de classe de uso do solo na bacia da Nascente do Sapé, calculada pelo método da Unidade de Carga. Fonte: Elaborado pela autora.

\begin{tabular}{|l|c|c|c|c|c|}
\hline Produção das Classes de Uso do Solo para Bacia da Nascente do Sapé \\
\hline Classe & $\begin{array}{c}\text { Área } \\
\left(\mathbf{K m}^{\mathbf{2}}\right)\end{array}$ & $\begin{array}{c}\mathbf{N} \text { total } \\
(\mathbf{k g} / \mathbf{d i a})\end{array}$ & $\begin{array}{c}\mathbf{P} \text { total } \\
(\mathbf{k g} / \mathbf{d i a})\end{array}$ & $\begin{array}{c}\text { Ss Total } \\
\text { (kg/dia) }\end{array}$ & $\begin{array}{c}\text { Carga Gerada } \\
\text { (Kg/dia) }\end{array}$ \\
\hline Tecido Urbano Contínuo & 0,1269 & 0,1616 & 0,0043 & 6,3433 & 6,5092 \\
\hline Indústria, Comércio e Equipamentos Gerais & 0,0904 & 0,1090 & 0,0029 & 4,2795 & 4,3915 \\
\hline Redes Viárias e Ferroviárias e espaços associados & 0,3471 & 0,3050 & 0,0081 & 11,9718 & 12,2850 \\
\hline Espaços Verdes Urbanos & 0,0251 & 0,0091 & 0,0002 & 0,3554 & 0,3647 \\
\hline Equipamentos desportivos e de lazer & 0,0047 & 0,0022 & 0,0001 & 0,0859 & 0,0881 \\
\hline Total & $\mathbf{0 , 5 9 4 2}$ & $\mathbf{0 , 5 8 7 0}$ & $\mathbf{0 , 0 1 5 7}$ & $\mathbf{2 3 , 0 3 5 9}$ & $\mathbf{2 3 , 6 3 8 6}$ \\
\hline
\end{tabular}

Tabela 27 - Produção de carga difusa para as diferentes parcelas de classe de uso do solo na bacia do Córrego Ibiraporã, calculada pelo método da Unidade de Carga. Fonte: Elaborado pela autora.

\begin{tabular}{|l|c|c|c|c|c|}
\hline Produção das Classes de Uso do Solo para Bacia do Córrego Ibiraporã \\
\hline Classe & $\begin{array}{c}\text { Área } \\
\left(\mathbf{K m}^{\mathbf{2}}\right)\end{array}$ & $\begin{array}{c}\mathbf{N} \text { total } \\
(\mathbf{k g} / \text { dia) }\end{array}$ & $\begin{array}{c}\text { P total } \\
(\mathbf{k g} / \text { dia) }\end{array}$ & $\begin{array}{c}\text { Ss Total } \\
\text { (kg/dia) }\end{array}$ & $\begin{array}{c}\text { Carga Gerada } \\
\text { (Kg/dia) }\end{array}$ \\
\hline Tecido Urbano Contínuo & 0,1505 & 0,1917 & 0,0051 & 7,5254 & 7,7222 \\
\hline Tecido Urbano Descontínuo & 0,1812 & 0,1935 & 0,0052 & 7,5945 & 7,7932 \\
\hline Redes Viárias e Ferroviárias e espaços associados & 0,6656 & 0,5849 & 0,0156 & $\mathbf{2 2 , 9 5 6 7}$ & 23,5572 \\
\hline Espaços Verdes Urbanos & 0,0586 & 0,0212 & 0,0006 & 0,8309 & 0,8526 \\
\hline Equipamentos desportivos e de lazer & 0,1115 & 0,0518 & 0,0014 & 2,0349 & 2,0882 \\
\hline Total & $\mathbf{1 , 1 6 7 5}$ & $\mathbf{1 , 0 4 3 2}$ & $\mathbf{0 , 0 2 7 8}$ & $\mathbf{4 0 , 9 4 2 3}$ & $\mathbf{4 2 , 0 1 3 4}$ \\
\hline
\end{tabular}

Dividindo a produção total pela área da bacia é possível obter a produção em $\mathrm{kg} / \mathrm{km}^{2} / \mathrm{dia}$. Obteve-se para as bacias em estudo as seguintes produções de carga difusa, $39,782 \mathrm{~kg} / \mathrm{km}^{2} /$ dia para a Nascente do Sapé e $35,986 \mathrm{~kg} / \mathrm{km}^{2} /$ dia para o Córrego Ibiraporã, portanto apresentam produções parecidas. Pode-se atribuir as diferenças apresentadas na despoluição dos dois corpos d'água, em parte, ao programa de gestão participativa implantado na bacia do Córrego Ibiraporã.

\subsubsection{Acumulo de carga difusa na superfície da bacia}

O acumulo de carga difusa na superfície da bacia é afetado principalmente por dois fatores, pela varrição e pela ocorrência de precipitação. Com relação à varrição, vimos que segundo Novotny (1985) uma varrição com alto rendimento reduz cerca de: $25 \%$ do material fino, $50 \%$ do mediano e $75 \%$ do grosseiro; resultando na redução de poluentes no escoamento superficial efetiva de apenas $15 \%$. Já com relação à precipitação o que determina a eficiência da remoção é a intensidade da chuva. O potencial de remoção de material particulado varia em 
função da intensidade da precipitação, portanto utilizando a classificação de chuvas de Reichardt (1987) apresentada na Tabela 28 e a capacidade de remoção do material particulado depositado sobre superfícies impermeáveis da Agência de Proteção Ambiental dos Estados Unidos (1986), apresentados na Tabela 29, a seguir, foi possível estimar a influência da precipitação na lavagem da bacia.

Tabela 28 - Classificação das Chuvas. Fonte: Adaptado de Reichardt (1987).

\begin{tabular}{|l|l|}
\hline CLASSIFICAÇÃO DAS CHUVAS \\
\hline FRACA & ATÉ $2,5 \mathrm{~mm} / \mathrm{h}$ \\
\hline MODERADA & DE 2,5 A $7,5 \mathrm{~mm} / \mathrm{h}$ \\
\hline FORTE & ACIMA DOS $7,5 \mathrm{~mm} / \mathrm{h}$ \\
\hline
\end{tabular}

Tabela 29 - Intensidade de chuva para remoção do material particulado depositado sobre superfícies impermeáveis. Fonte: Adaptado de USEPA (1986).

\begin{tabular}{|l|l|}
\hline Intensidade de chuva para remoção do material particulado \\
\hline $\mathbf{3 0 \%}$ & $4,2 \mathrm{~mm} / \mathrm{h}$ \\
\hline $\mathbf{6 0 \%}$ & $8,5 \mathrm{~mm} / \mathrm{h}$ \\
\hline $\mathbf{9 0 \%}$ & $12,7 \mathrm{~mm} / \mathrm{h}$ \\
\hline
\end{tabular}

Assim, partindo das seguintes premissas, que chuvas fracas têm um potencial de remoção de $20 \%$, chuvas moderadas de $50 \%$ e chuvas fortes de $90 \%$, que a varrição tem o potencial de remoção de $15 \%$ e do potencial de geração de carga difusa para as bacias em questão, simplificando o processo é possível criar um algoritmo para modelar a condição do solo da bacia para diferentes cenários. $O$ algoritmo criado é apresentado na Equação 4 a seguir.

$$
R_{\text {Sup } . i}=\left(R_{\text {Sup } . ~-1}+P_{\text {diária i }}\right) \cdot N_{\text {varrição } i} \cdot N_{\text {chuva } i}
$$

(Equação 4 - Elaborada pela autora)

Onde: $R_{\text {Sup. } \mathrm{i}}=$ Residual na superfície da bacia $\left(\mathrm{Kg} / \mathrm{Km}^{2}\right) ; \mathrm{R}_{\text {Sup. } \mathrm{i}-1}$ Residual na superfície da bacia no dia anterior $\left(\mathrm{Kg} / \mathrm{Km}^{2}\right) ; P_{\text {diária } \mathrm{i}}=$ Produção diária da bacia $\left(\mathrm{Kg} / \mathrm{Km}^{2}\right) ; N_{\text {varrição } \mathrm{i}}=$ Porcentagem do material não removido por varrição; e $\mathrm{N}_{\text {chuva } \mathrm{i}}=$ Porcentagem do material não removido pela chuva.

Aplicando o algoritmo para os cenários: 1) Sem chuva e com varrição diária; 2) Sem chuva e sem varrição; 3) Com chuva fraca a cada 3 dias e com varrição diária; 4) Com chuva moderada a cada 2 dias e com varrição diária; 5) Chuva forte a cada 2 dias e com varrição diária; e 6) Com chuva forte todos os dias e com varrição 
diária, obteve-se os resultados mostrados na Tabela 30 e na Tabela 31 para a Nascente do Sapé e para o Córrego lbiraporã respectivamente.

Tabela 30 - Acumulo de carga difusa na superfície da bacia - Nascente do Sapé. Fonte: Elaborado pela autora.

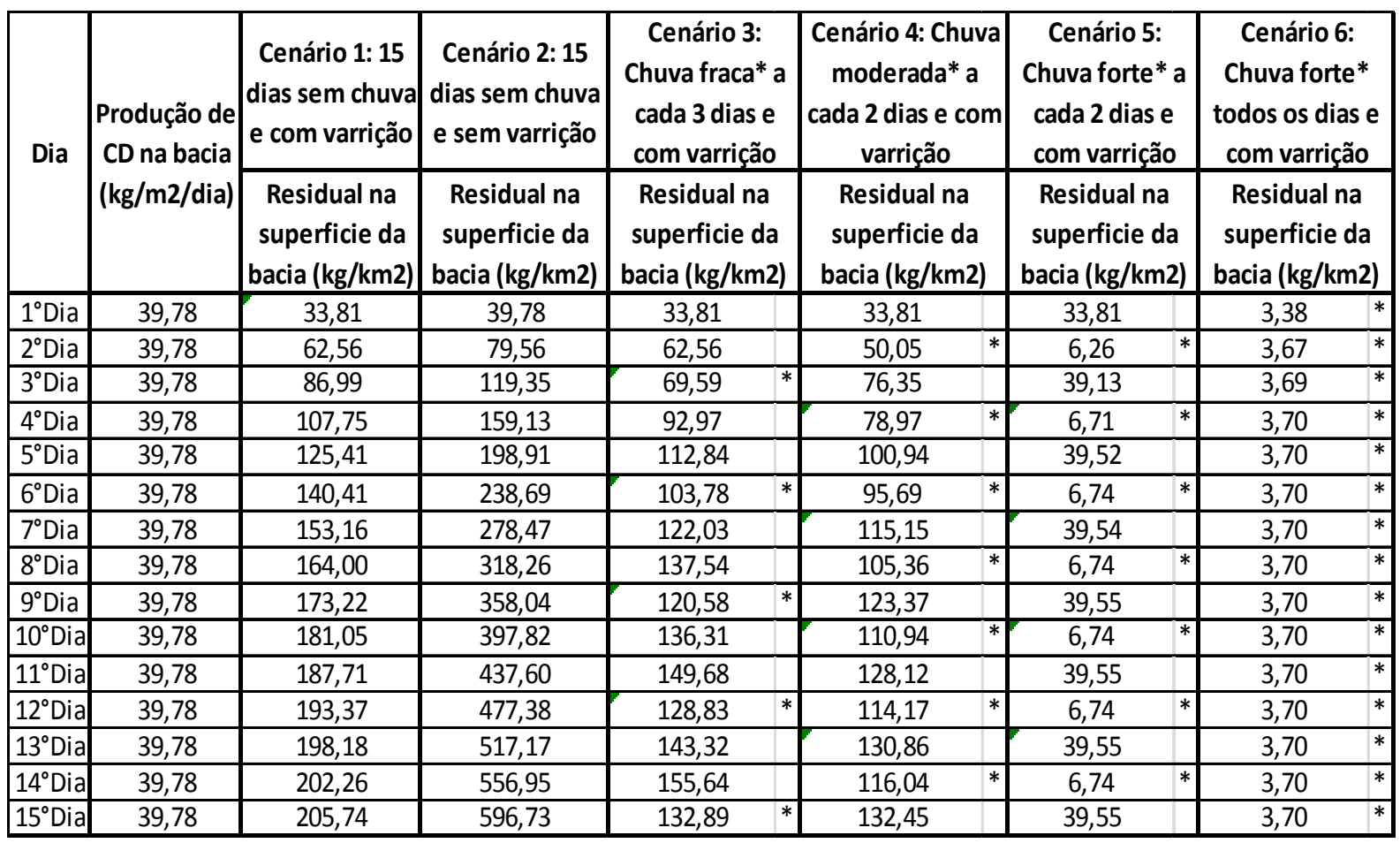

Tabela 31 - Acumulo de carga difusa na superfície da bacia - Córrego lbiraporã. Fonte: Elaborado pela autora.

\begin{tabular}{|c|c|c|c|c|c|c|c|c|c|}
\hline \multirow[t]{2}{*}{ Dia } & \multirow{2}{*}{$\begin{array}{l}\text { Produção de } \\
\text { CD na bacia } \\
\text { (kg/m2/dia) }\end{array}$} & $\begin{array}{l}\text { Cenário 1: } 15 \\
\text { dias sem chuva } \\
\text { e com varrição }\end{array}$ & $\begin{array}{c}\text { Cenário 2: } 15 \\
\text { dias sem chuva } \\
\text { e sem varrição }\end{array}$ & $\begin{array}{c}\text { Cenário 3: } \\
\text { Chuva fraca* a } \\
\text { cada } 3 \text { dias e } \\
\text { com varrição }\end{array}$ & $\begin{array}{c}\text { Cenário 4: Chuv } \\
\text { moderada* a } \\
\text { cada } 2 \text { dias e co } \\
\text { varrição }\end{array}$ & & $\begin{array}{c}\text { Cenário 5: } \\
\text { Chuva forte* } \\
\text { cada } 2 \text { dias e } \\
\text { com varrição }\end{array}$ & & $\begin{array}{c}\text { Cenário 6: } \\
\text { Chuva forte* } \\
\text { todos os dias e } \\
\text { com varrição }\end{array}$ \\
\hline & & $\begin{array}{c}\text { Residual na } \\
\text { superficie da } \\
\text { bacia }(\mathrm{kg} / \mathrm{km} 2)\end{array}$ & $\begin{array}{c}\text { Residual na } \\
\text { superficie da } \\
\text { bacia }(\mathrm{kg} / \mathrm{km} 2)\end{array}$ & $\begin{array}{c}\text { Residual na } \\
\text { superficie da } \\
\text { bacia (kg/km2) }\end{array}$ & $\begin{array}{c}\text { Residual na } \\
\text { superficie da } \\
\text { bacia }(\mathrm{kg} / \mathrm{km} 2)\end{array}$ & & $\begin{array}{c}\text { Residual na } \\
\text { superficie da } \\
\text { bacia (kg/km2 }\end{array}$ & & $\begin{array}{c}\text { Residual na } \\
\text { superficie da } \\
\text { bacia (kg/km2) }\end{array}$ \\
\hline $1^{\circ} \mathrm{Dia}$ & 35,99 & 30,59 & 35,99 & 30,59 & 30,59 & & 30,59 & & 3,06 \\
\hline $2^{\circ} \mathrm{Dia}$ & 35,99 & 56,59 & 71,97 & 56,59 & 45,27 & & 5,66 & & 3,32 \\
\hline $3^{\circ} \mathrm{Dia}$ & 35,99 & 78,69 & 107,96 & 62,95 & 69,07 & & 35,40 & & 3,34 \\
\hline $4^{\circ} \mathrm{Dia}$ & 35,99 & 97,47 & 143,95 & 84,10 & 71,44 & & 6,07 & & 3,34 \\
\hline $5^{\circ} \mathrm{Dia}$ & 35,99 & 113,44 & 179,93 & 102,07 & 91,31 & & 35,75 & & 3,34 \\
\hline $6^{\circ} \mathrm{Dia}$ & 35,99 & 127,01 & 215,92 & 93,88 & 86,56 & 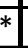 & 6,10 & & 3,34 \\
\hline $7^{\circ} \mathrm{Dia}$ & 35,99 & 138,55 & 251,91 & 110,39 & 104,17 & & 35,77 & & 3,34 \\
\hline $8^{\circ} \mathrm{Dia}$ & 35,99 & 148,36 & 287,89 & 124,42 & 95,30 & & 6,10 & & 3,34 \\
\hline $9^{\circ} \mathrm{Dia}$ & 35,99 & 156,69 & 323,88 & 109,07 & 111,60 & & 35,77 & & 3,34 \\
\hline $10^{\circ} \mathrm{Dia}$ & 35,99 & 163,78 & 359,86 & 123,30 & 100,36 & & 6,10 & & 3,34 \\
\hline $11^{\circ} \mathrm{Dia}$ & 35,99 & 169,80 & 395,85 & 135,39 & 115,89 & & 35,77 & & 3,34 \\
\hline $12^{\circ} \mathrm{Dia}$ & 35,99 & 174,92 & 431,84 & 116,54 & 103,28 & . & 6,10 & & 3,34 \\
\hline $13^{\circ} \mathrm{Dia}$ & 35,99 & 179,27 & 467,82 & 129,65 & 118,37 & & 35,77 & & 3,34 \\
\hline $14^{\circ} \mathrm{Dia}$ & 35,99 & 182,97 & 503,81 & 140,79 & 104,97 & & 6,10 & & 3,34 \\
\hline $15^{\circ} \mathrm{Dia}$ & 35,99 & 186,11 & 539,80 & 120,21 & 119,81 & & 35,77 & & 3,34 \\
\hline
\end{tabular}


Podemos observar nos resultados obtidos para estas simulações o importante papel da varrição na remoção de poluentes na superfície da bacia, uma vez que há uma concentração de poluentes significativamente maior no cenário sem chuva e sem varrição. Segundo o Centro de Gerenciamento de Emergências - CGE (s/d), órgão da Prefeitura de São Paulo a estiagem mais intensa pela qual a capital de São Paulo já passou foi de 78 dias sem chuva no ano de 1985. Utilizando o mesmo algoritmo é possível estimar o acumulo de carga difusa para ambas as bacias em um período de 78 dias sem chuva e sem varrição, a fim de obter um índice de qualidade da superfície da bacia, sendo o valor máximo aquele acumulado em 78 dias e o mínimo em 1 dia. Considerando que uma bacia urbana densa típica com $30 \%$ de sua área ocupada por viário, $65 \%$ por residências e $5 \%$ por áreas de lazer, temos os seguintes resultados:

- $\mathrm{CD}$ produzida $=(30 \% 35,39)+(65 \% 51,31)+(5 \% 18,73)=44,90 \mathrm{Kg} / \mathrm{Km}^{2} / \mathrm{dia}$

- Rsup bacia em 78 dias $=78.44,90=3502,50 \mathrm{Kg} / \mathrm{Km}^{2}$

- Se, na ausência de varrição, em 1 dia há o acumulo de $44,90 \mathrm{Kg} / \mathrm{Km}^{2}$ e em 78 dias de $3502,50 \mathrm{Kg} / \mathrm{Km}^{2}$, temos um gradiente que varia de 44,90 a 3502,50 $\mathrm{Kg} / \mathrm{Km}^{2}$

Com base no gradiente obtido foi proposto o índice de qualidade da superfície da bacia mostrado na Tabela 32, a seguir.

Tabela 32 - Índice de qualidade da superfície da bacia. Fonte: Elaborado pela autora.

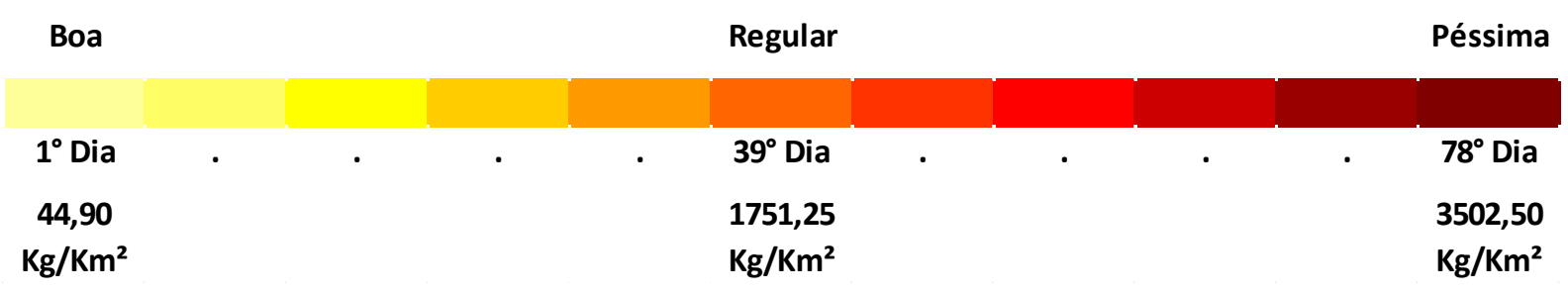

Portanto, o índice nos diz que longos períodos sem precipitação podem tornar a qualidade do solo da bacia péssima, situação comum no inverno, e que durante o verão quando há a ocorrência de chuvas fortes praticamente todos os dias, a superfície da bacia fica com qualidade ótima. E tal raciocínio pode ser aplicado à qualidade da água no corpo d'água destas bacias, uma vez que os poluentes retidos na bacia são levados ao corpo d'água pelo escoamento superficial. 
Por exemplo, ao passar por um longo período de estiagem, a primeira chuva carregará para o corpo d'água, de acordo com sua intensidade, a carga difusa que havia sido retida na bacia no período. Aplicando a classificação obtida na Tabela 32, podemos estimar a qualidade da superfície de uma bacia hipotética e semelhante às do estudo. A llustração 56 mostra o modelo da evolução da qualidade do solo nesta bacia, com base no que foi discutido, para alguns cenários estabelecidos.

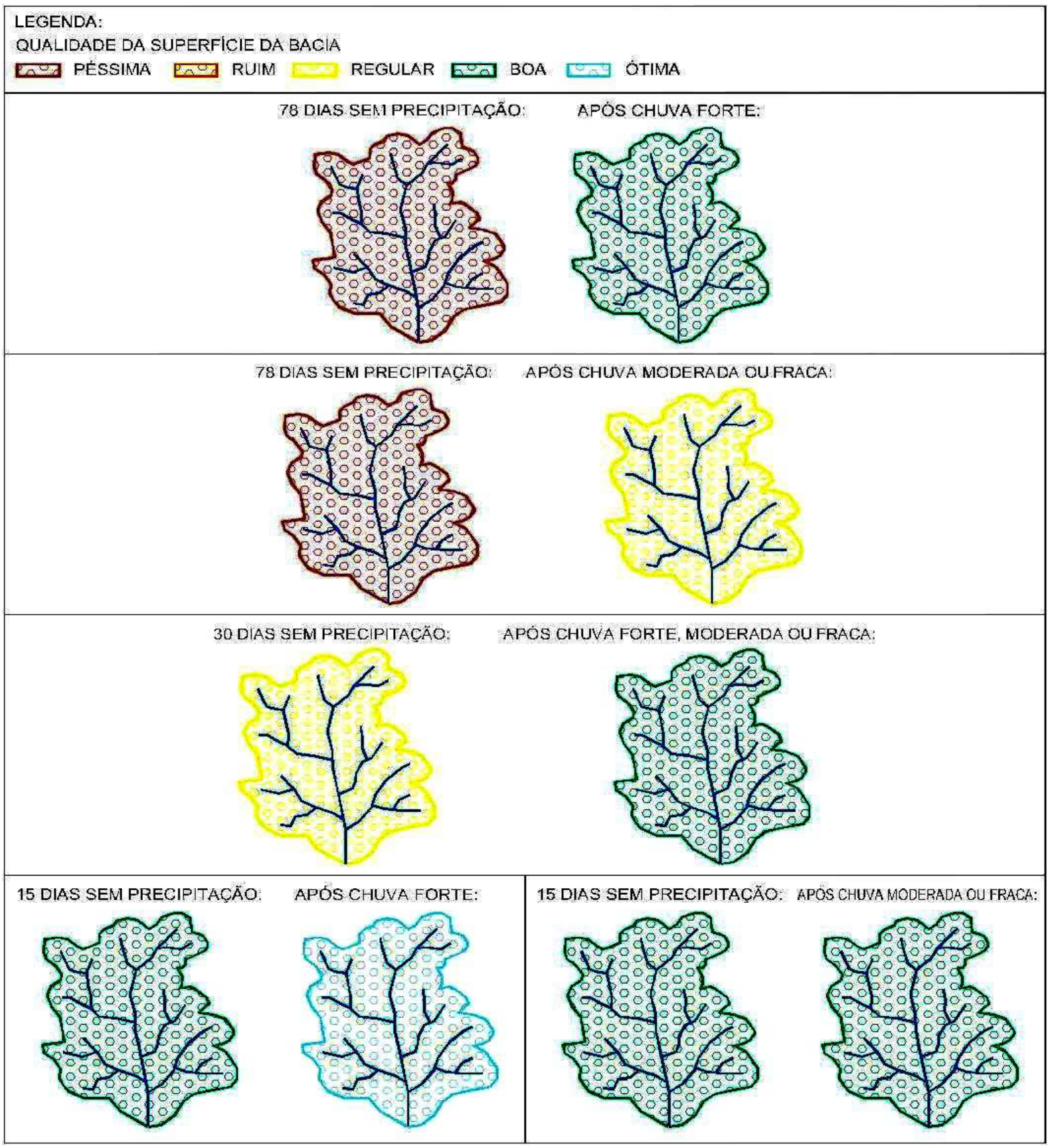

llustração 56 - Evolução da qualidade da superfície do solo em uma bacia hipotética. Fonte: Elaborado pela autora. 


\subsection{COMUNIDADE BENTÔNICA}

\subsubsection{Metodologia}

Para avaliação biológica foram utilizados índices de quantificação da comunidade bentônica para estudo das diferenças apresentadas na sua estrutura no período seco e no período chuvoso, pois sabendo que no período seco há a redução na qualidade da água dos corpos d'água que passam por esta sazonalidade, devido à redução de sua vazão e o acumulo da carga difusa na bacia que chega ao corpo d'água de forma mais concentrada nas ocorrências pontuais de precipitação, esperase encontrar diferenças na estrutura da comunidade bentônica nos dois períodos. $O$ objeto deste estudo para avaliação da comunidade bentônica serão a Nascente do Sapé e o Córrego Ibiraporã, para tanto. No caso da Nascente do Sapé, por tratar-se de um canal com fundo em Gabião, foram testadas armadilhas com substrato para coleta de organismos bentônicos; Já para o Córrego Ibiraporã foram realizadas coletas através do uso do amostrador tipo Surber com abertura de malha de 250 micrômetros para coleta da comunidade bentônica. $O$ uso das duas técnicas é descrito nos itens seguintes.

Realizada a amostragem, os indivíduos foram acondicionados em recipientes identificados, onde foram fixados (Dia da coleta, local e tipo de armadilha no rótulo do recipiente). A fixação destes organismos foi feita através do uso de formalina a $4 \%$. Os organismos coletados foram identificados até o nível taxonômico mais relevante para cada grupo. Utilizou-se a chave de identificação de Fernandez e Domingues (2001) e outras disponíveis. A identificação dos organismos permitiu sua quantificação, que tornou possível a aplicação dos seguintes índices para estudo da estrutura da comunidade bentônica: Índice DiB (Diversidade Biológica), Índice RB (Riqueza Biológica), Índice EB (Equitabilidade Biológica), Índice DoB (Dominância Biológica), Índice BF (Biótico de Famílias de Hilsenhoff) e Índice EPT (Ephemeroptera, Plecoptera e Trichoptera).

\subsubsection{Coleta através de amostrador tipo Surber}

O amostrador tipo Surber é recomendado para corpos d'água rasos, condição típica de corpos d'água de primeira ordem, que segundo Strahler (1952) e 
Horton (1945) são aqueles que não apresentam tributários, ou seja, são canais de cabeceira das bacias de drenagem, como os utilizados no estudo. A Tabela 33, a seguir, mostra a classificação de canais segundo Strahler (1952) e Horton (1945).

Tabela 33 - Classificação de canais segundo Strahler (1952) e Horton (1945). Fonte: Adaptado de Strahler (1952) e Horton (1945).

\begin{tabular}{|l|l|}
\hline Classificação de Canais de Strahler (1952) e Horton (1945) \\
\hline Canais: & Caracteristicas: \\
\hline de primeira ordem: & aqueles que não possuem tributários, afluentes. \\
\hline de segunda ordem: & somente recebem afluente de primeira ordem. \\
\hline de terceira ordem: & $\begin{array}{l}\text { podem receber um ou mais afluente de segunda ordem e também de } \\
\text { primeira ordem. }\end{array}$ \\
\hline de quarta ordem: & $\begin{array}{l}\text { recebem afluentes de terceira ordem e de outra ordem inferior. E assim } \\
\text { sucessivamente. }\end{array}$ \\
\hline $\begin{array}{l}\text { Entre dois canais confluentes será classificado como de ordem superior aquele que se } \\
\text { apresentar maior comprimento. }\end{array}$ \\
\hline $\begin{array}{l}\text { O rio principal da bacia é identificado pela mesma ordem da sua nascente até a sua } \\
\text { desembocadura. }\end{array}$ \\
\hline
\end{tabular}

Para realização da coleta, deve-se posicionar o amostrador contra a correnteza e fixar a área de amostragem no leito do corpo d'água, a seguir com o auxílio de uma espátula ou pá deve-se revolver o substrato da área de amostragem, a fim de que os organismos sejam levados pelo fluxo d'água para dentro da rede do amostrador, por fim, deve-se acondicionar o material coletado em um recipiente para encaminha-los para fixação (SILVEIRA, 2004). O procedimento está demonstrado na Figura A da llustração 57 e na Figura B podemos visualizar um amostrador tipo Surber comercial.

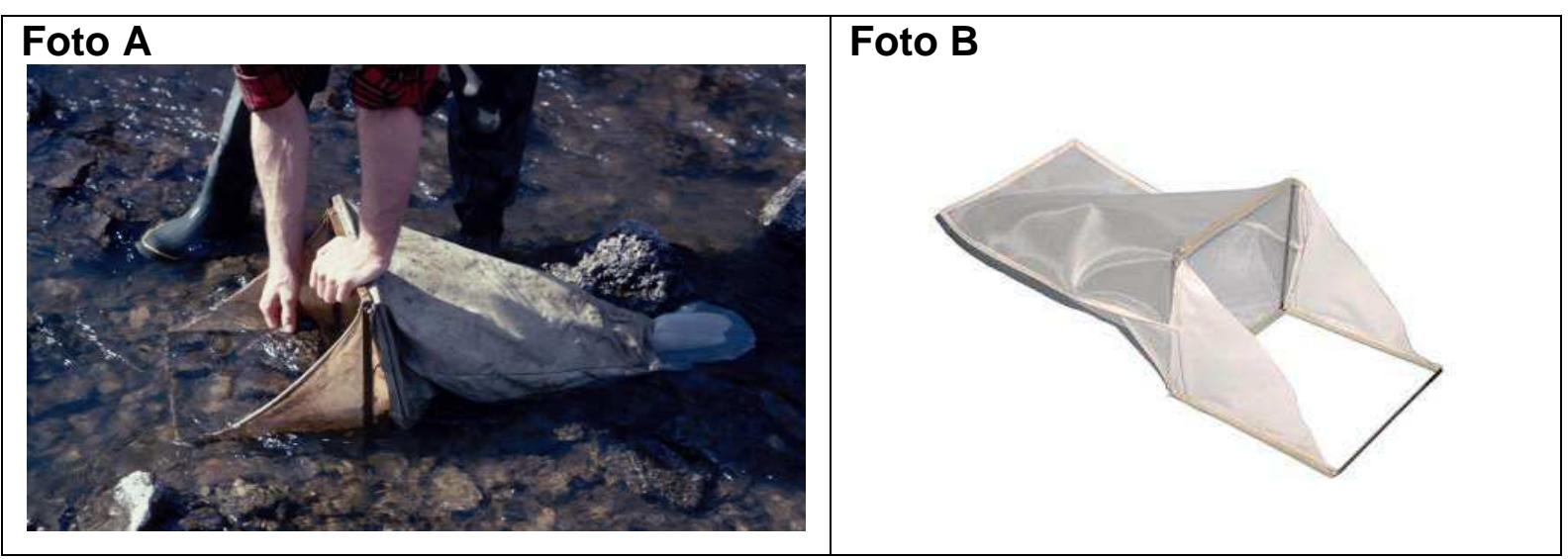

Ilustração 57 - Utilização do amostrador tipo Surber (Foto A). Amostrador tipo Surber Comercial. (Foto B). Fonte: ASLO (s/d) por Ray Drenner. 


\subsection{Comunidade bentônica: Córrego Ibiraporã}

Para avaliação da comunidade bentônica do Córrego Ibiraporã foi realizada a coletada de com o amostrador tipo Surber, uma vez que o fundo do canal possui substrato que torna possível seu uso. A primeira coleta foi realizada em 11/09/2012 (Período seco) e a segunda em 30/01/2013 (Período chuvoso) e em dois pontos do canal, próximo à estaca 9 e à estaca 16 como mostrado na llustração 58 a seguir.

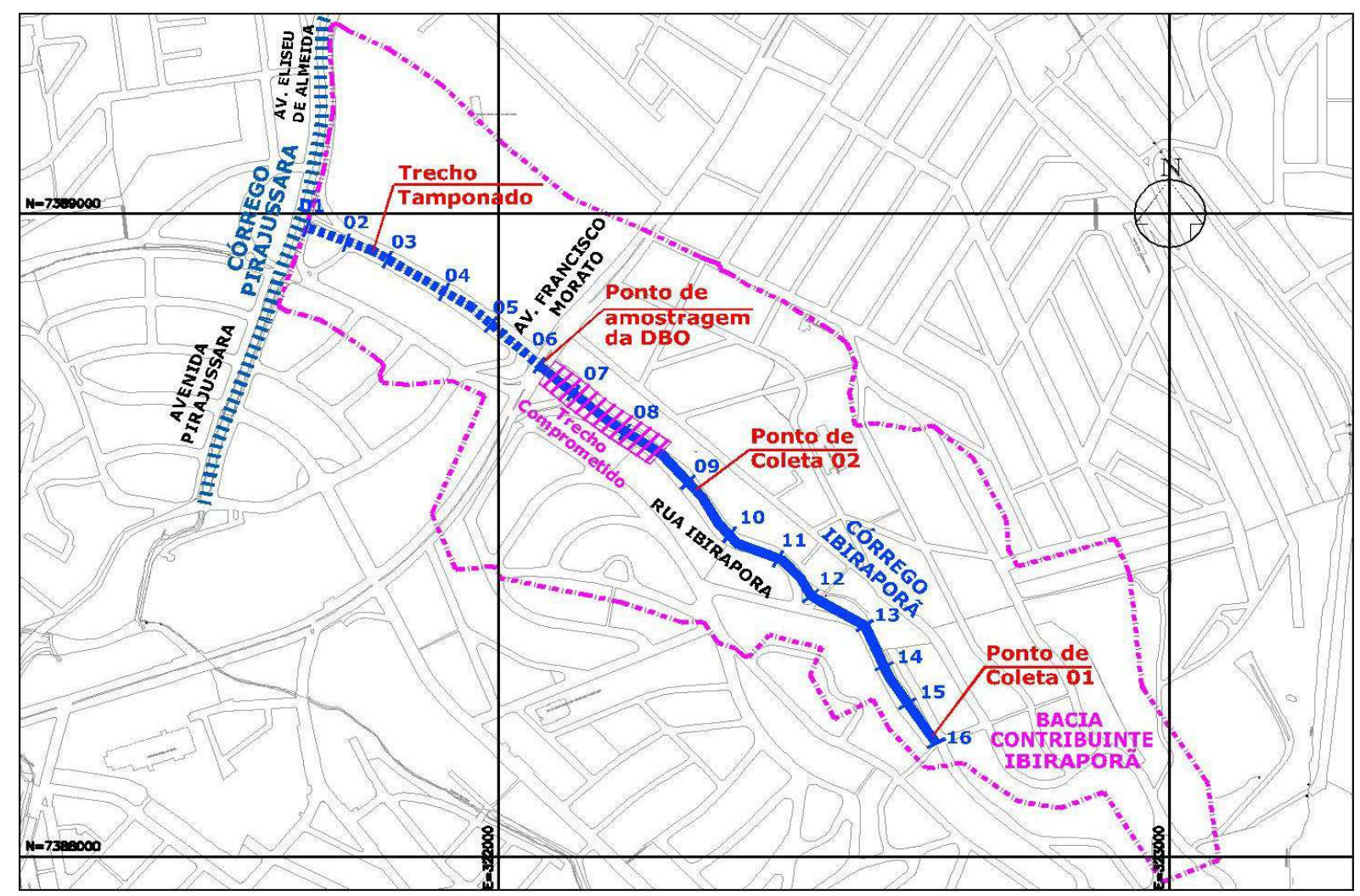

llustração 58 - Córrego Ibiraporã: Pontos de Coleta dos organismos bentônicos. Fonte: Elaborado pela autora.

No momento da coleta foi constatada a presença de alguns lançamentos irregulares no trecho final do canal (conforme mostrado na llustração 40), portanto a escolha dos dois pontos se deu de modo a excluir tal trecho sobre influência destas cargas pontuais, uma vez que o que pretende se avaliar é o processo de recuperação, bem como a influência da carga difusa. Em cada ponto foram realizadas 8 amostragens com utilização do Suber, gerando um total de 32 amostras (16 coletadas no período seco e outras 16 no período chuvoso). Tais amostras foram identificadas com os seguintes prefixos conforme seu local e período de coleta: AxPyTz, onde "A" se refere a amostra, " $x$ " ao número da amostra (1 a 32), "P" ao 
ponto de coleta, "y" ao número do ponto de coleta (1 ou 2), "T" a período de coleta, "z" ao tipo de tempo ("S" para seco e "C" para chuvoso). Exemplo: A1P1TS = Amostra de número 1, coletada no ponto 1 e durante o período seco.

Para realização da coleta de cada amostra o coletor foi posicionado contra a correnteza e sua área de amostragem agitada com auxilio de uma espátula por 30 segundos (Foto $A$ e $B$ ), a fim de permitir que o material biológico pudesse ser coletado. O material coletado foi acondicionado em sacos resistentes identificados, fixado com formol e levado para o laboratório. A llustração 59 demonstra o procedimento adotado.

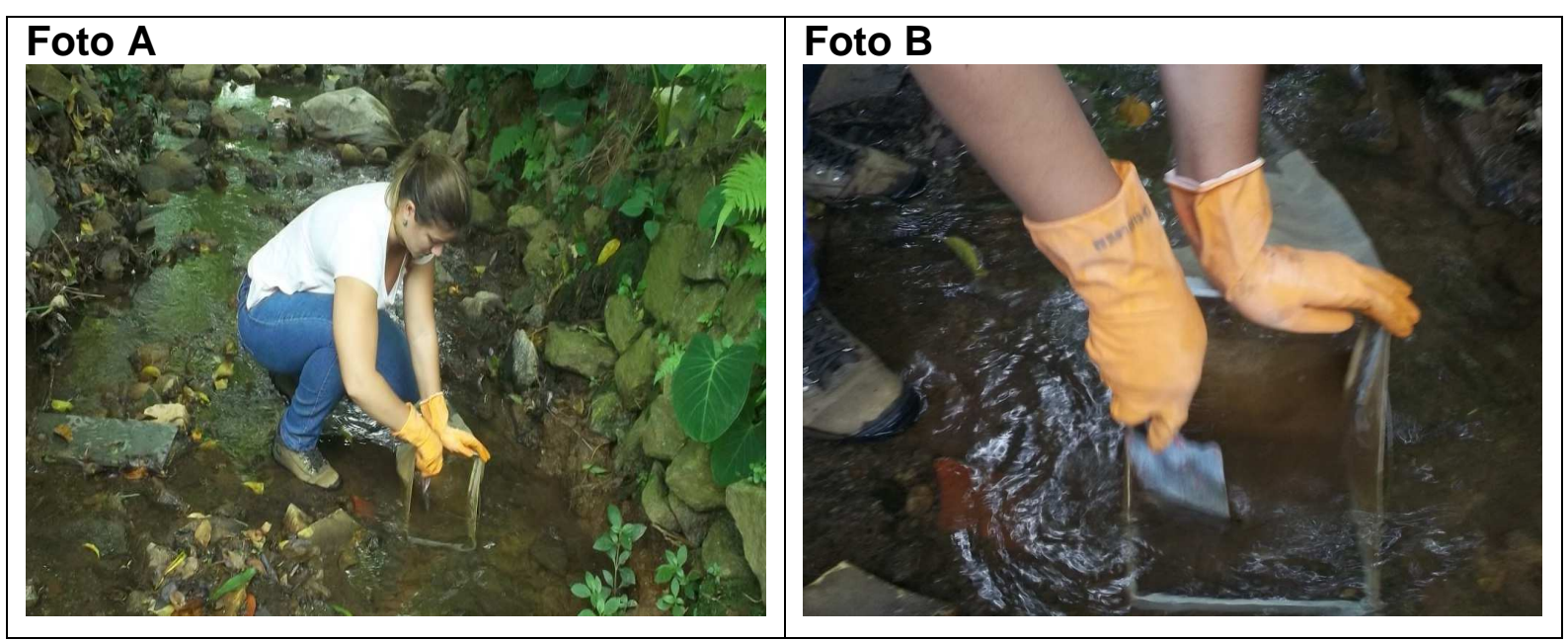

Ilustração 59 - Córrego Ibiraporã: Coleta das amostras. Fonte: Fotos da autora.

A sequência de fotos a seguir apresentadas na llustração 60 mostra a metodologia de preparo das amostras coletadas para triagem. De posse do material coletado em laboratório este foi lavado e peneirado com auxilio da peneira de abertura $0,50 \mathrm{~mm}$ (Foto $A, B$ e $H$ ), em seguida o material retido na peneira (Foto $G$ ) foi acondicionado em recipientes plásticos identificados (Foto $C$ e I), sendo preservados em álcool 70\% (Foto D) e corados com Rosa de Bengala (Foto E e F). 


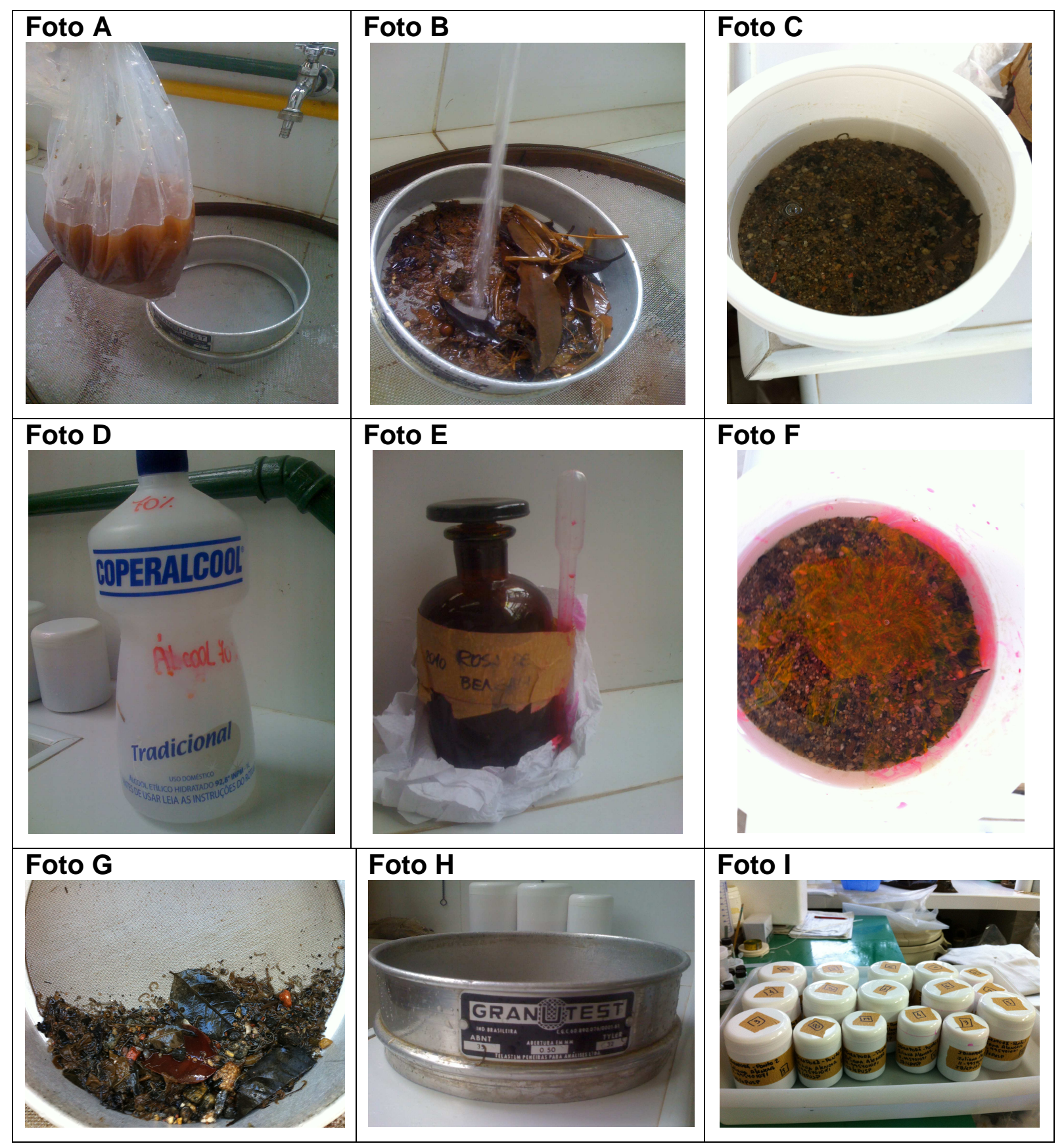

Ilustração 60 - Córrego lbiraporã: Preparo das amostras para triagem. Fonte: Fotos da autora.

\subsubsection{Coleta através de instalação de armadilha com substrato}

Nos corpos de primeira ordem, o uso de armadilhas com substrato e recomendado quando o substrato presente não permite a utilização do amostrador tipo Surber. Em corpos d'água onde houve intervenções como a canalização, o uso de gabião no leito do canal impede o uso do amostrador tipo Surber, já que não é possível retirar substrato para coleta dos organismos, esse impedimento exige a 
montagem de um sistema que permita a colonização por parte dos organismos, tornando possível também a padronização do substrato em pontos distintos. As armadilhas devem ser colocadas no leito do canal, de forma que elas fiquem totalmente submersas, devendo ser feita a ancoragem destas, para que não sejam levadas pela correnteza. As armadilhas devem ser mantidas idealmente por três semanas, período suficiente para que a armadilha se integre ao ecossistema e passe a ser utilizada como substrato, permitindo assim a coleta futura dos organismos ali residentes. Após este período, as armadilhas devem ser retiradas e acondicionadas em sacos plásticos, onde serão fixadas. A llustração 61 mostra o tipo de armadilha mais usada para amostragem de macroinvertebrados bentônicos. A foto $A$ e $B$ mostram armadilhas com substratos de diferentes tamanhos.
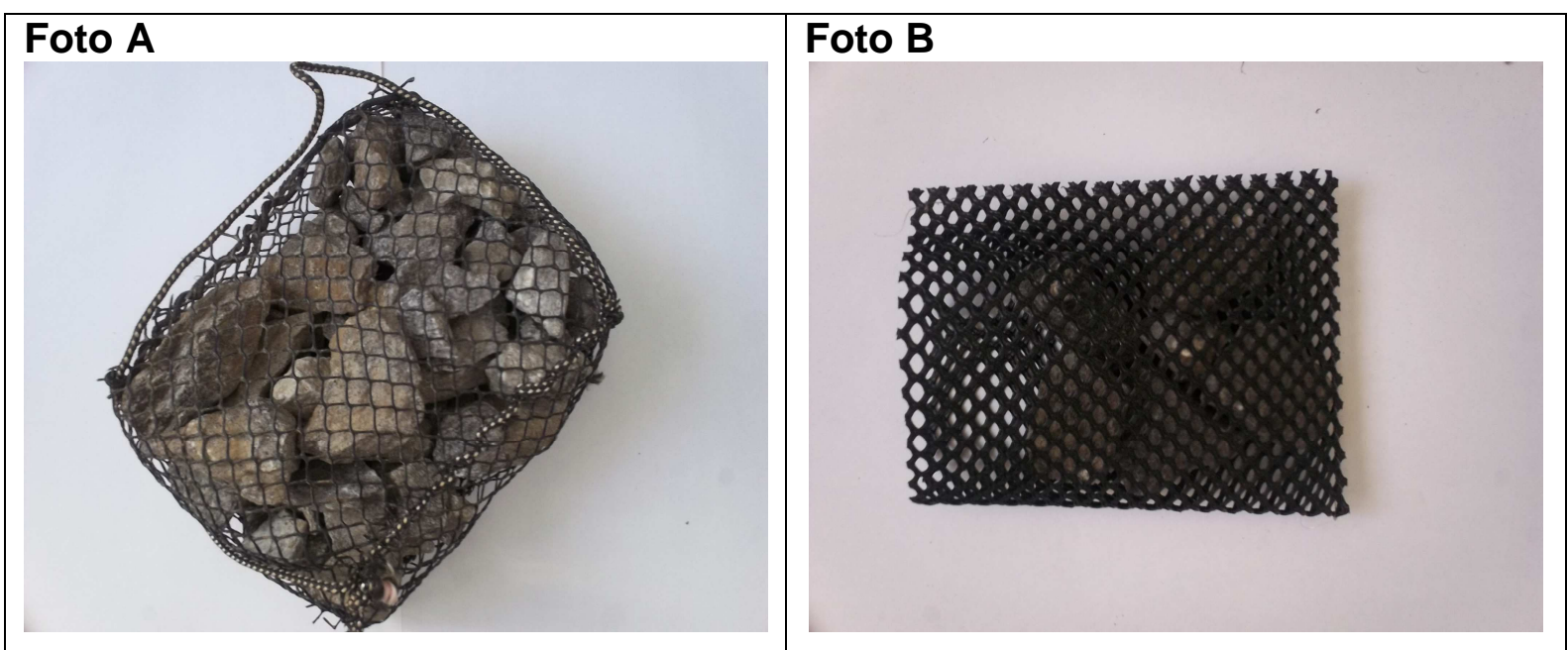

llustração 61 - Armadilhas com substrato para coleta de macroinvertebrados bentônicos - Foto A e B. Fonte: Fotos da autora.

\subsection{Comunidade bentônica: Nascente do Sapé}

A Nascente do Sapé possui fundo em gabião, portanto foi necessária a confecção de armadilhas biológicas. Para instalação das armadilhas foram usados três pontos, inicio, meio e final do trecho contemplado pelo programa, onde foram instaladas 6 armadilhas por ponto. Para montagem das armadilhas foi usado substrato natural (vegetação coletada no fundo do canal e seca em estufa a $100^{\circ}$ por 24h) e brita 3. A sequência de fotos na llustração 62 mostra como o procedimento foi realizado. 

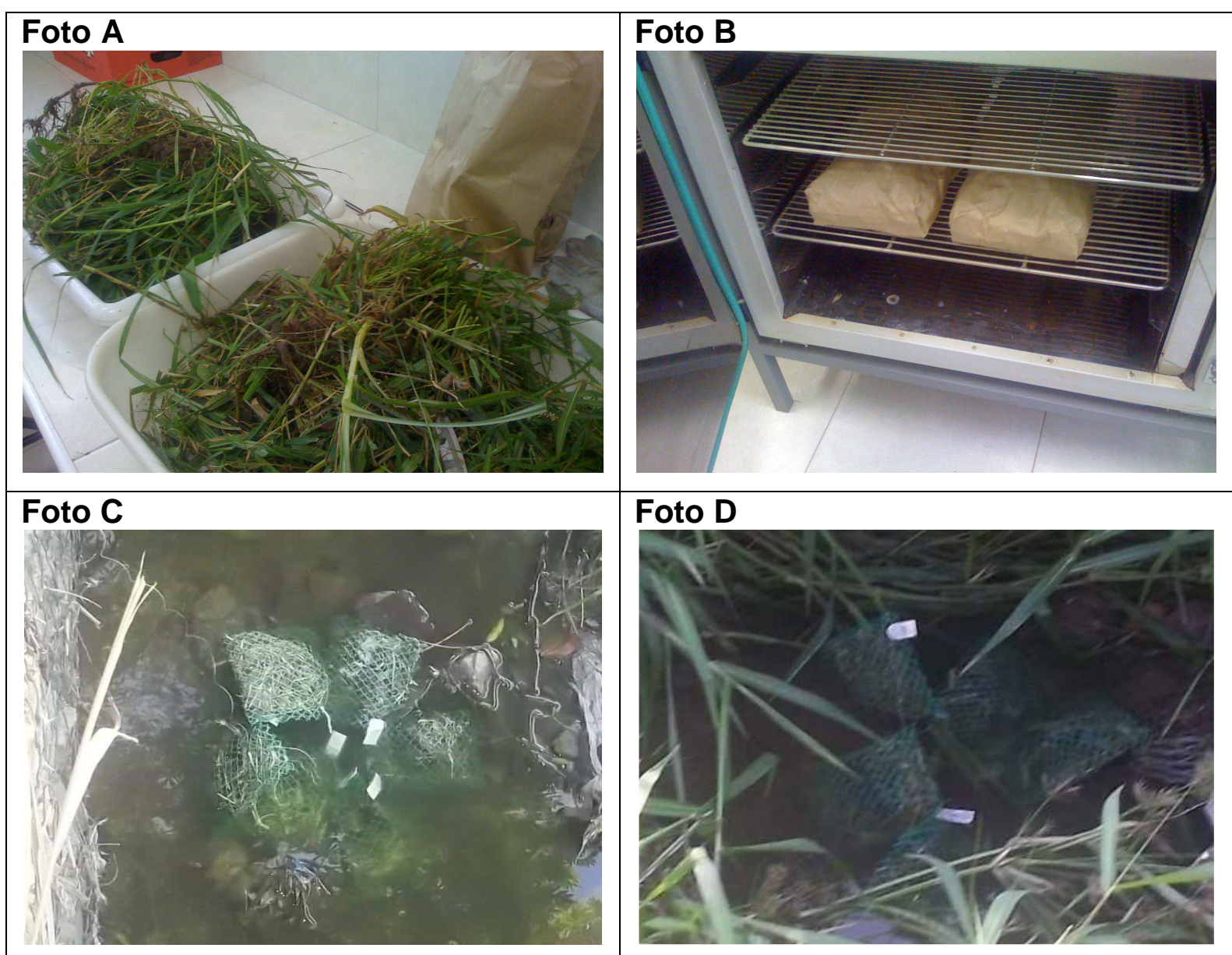

Foto D

llustração 62 - Fotos A e B: Preparo das armadilhas biológicas. Foto C e D: Armadilhas biológicas instaladas na Nascente do Sapé. Fonte: Fotos da autora. 


\subsubsection{3 Índices biológicos utilizados}

\subsubsection{1 Índice de Diversidade biológica - H’}

Segundo Costa (2007) a diversidade pode ser quantificada com base no índice de diversidade de Shannon-Weaner, que é calculado através da Equação 5 a seguir. Quanto maior o valor do H', maior a diversidade apresentada pela comunidade.

$$
H^{\prime}=\frac{\left[N \ln (N)-\sum_{i=1}^{S} n_{i} \ln \left(n_{i}\right)\right]}{N}
$$

(Equação 5 - ZAR, 1996)

Onde: $\mathrm{H}^{\prime}$ = Índice de Shannon-Weaver; ni=Número de indivíduos amostrados da $\mathrm{i}^{\text {esima }}$ espécie; $\mathrm{N}$ = número total de indivíduos amostrados; $\mathrm{S}=$ número total de espécies amostradas; In = logaritmo de base neperiana.

\subsubsection{2 Índice de Riqueza biológica - S}

O uso da medida de riqueza de táxons é muito vantajoso, já que reflete diretamente a saúde do ecossistema. O índice e dado pela somatória do número de táxons presente em cada amostra, assim quanto maior o índice maior a riqueza do ambiente estudado (MAZZINI, 2007). Ou ainda é possível utilizar o estimador de riqueza de espécies de Jackknife de $1^{\underline{a}}$ ordem, através da Equação 6 apresentada a seguir, ou outros para indicar a suficiência amostral.

$$
E_{D}=S_{o b s}+s_{1}\left(\frac{f-1}{f}\right)
$$

(Equação 6 - Heltshe \& Forrester, 1983)

Onde: $\mathrm{S}_{\mathrm{obs}}$ é o número de espécies observadas; $\mathrm{S}_{1}$ o número de espécie que está presente em somente um agrupamento (espécie de um agrupamento) e f o número de agrupamento que contém $\mathrm{j}^{\text {esima }}$ espécie de um agrupamento. 


\subsubsection{3 Índice de Equitabilidade biológica - J'}

O índice de equitabilidade, expressa a distribuição do número de indivíduos entre as diferentes espécies, indicando se sua abundância é divergente ou semelhante. Tal índice pode ser calculado através do uso do índice de Pielou, mostrado na Equação 7 seguir (GOMES, 2004).

$$
\mathrm{J}^{\prime}=\frac{H^{\prime}(\text { observado })}{\text { H'máximo }^{\prime}}
$$

(Equação 7 - GOMES, 2004)

Onde: H'máx= $\ln (S) ; J^{\prime}=$ Equitabilidade de Pielou; $S=$ número total de espécies amostradas; $\mathrm{H}^{\prime}$ = índice de diversidade de Shannon-Weaver.

Decréscimos nos valores dos índices de Diversidade, Riqueza e Equitabilidade estão relacionados com aumento de níveis de estresse ambiental no ecossistema, sendo importante sua avaliação conjunta. Outra consequência é o aumento da dominância.

\subsubsection{4 Índice de Dominância biológica - C}

Para determinação da dominância em uma comunidade é possível utilizar o índice de Simpson, que mede a probabilidade de 2 indivíduos selecionados ao acaso dentro de uma amostra serem do mesmo grupo considerado (GOMES, 2004). O índice de Simpson é dado pela Equação 8 a seguir.

$$
C=1-\frac{\sum_{i=1}^{S} n_{i}\left(n_{i}-1\right)}{N(N-1)}
$$

(Equação 8 - ZAR, 1996)

Onde: $\mathrm{C}$ = índice de dominância de Simpson; $\mathrm{n}$ i = número de indivíduos amostrados da iesima espécie; $\mathrm{N}$ = número total de indivíduos amostrados.

\subsubsection{5 Índice Biótico de famílias de Hilsenhoff - IBF}

O índice BF foi desenvolvido para utilização em rios da América do Norte para avaliação da qualidade da água, no entanto, devido à simplicidade de seu calculo tem sido amplamente utilizado em outras regiões. $O$ índice consiste em 
atribuir pesos de 0 a 10 de tolerância à poluição orgânica a cada grupo taxonômico (Tabela 34), sendo atribuído 0 aos menos tolerantes e 10 aos mais tolerantes, e em seguida multiplicar estes pesos pelo número de indivíduos de cada táxon encontrado, os produtos resultantes então devem ser somados e divididos pelo número total de organismos na amostra (FERREIRO, 2007). A Equação 9 a seguir resume a metodologia de cálculo.

$$
I B F=\frac{\sum n_{i} a_{i}}{N}
$$

(Equação 9 - FERREIRO, 2007)

Onde: $\mathrm{n}_{\mathrm{i}}=$ Número de indivíduos do grupo taxonômico $\mathrm{i} ; \mathrm{a}_{\mathrm{i}}=$ valor de tolerância do grupo taxonômico i; e N = Número total de indivíduos.

Tabela 34 - Tolerância à poluição orgânica segundo o Índice Biótico de Famílias de Hilsenhoff. Fonte: Elaborado pela autora a partir de Ferreiro (2007).

\begin{tabular}{|l|c|l|c|}
\hline \multicolumn{1}{|c|}{ Grupo Taxonômico } & $\begin{array}{c}\text { Grau de } \\
\text { Tolerância (0 } \\
\mathbf{1 0}\end{array}$ & \multicolumn{1}{|c|}{ Grupo Taxonômico } & $\begin{array}{c}\text { Grau de } \\
\text { Tolerância } \\
\text { (0-10) }\end{array}$ \\
\hline Platyhelminthes: Turbellaria & 4 & Insecta: Coleoptera & 4 \\
\hline Nematoda & 10 & Insecta: Megaloptera & 2 \\
\hline Annelida: Oligochaeta & 8 & Insecta: Tanytarsus & 6 \\
\hline Annelida: Hirudinea & 10 & Insecta: Psychodidae & 6 \\
\hline Mollusca & 7 & Insecta: Tipulidae & 3 \\
\hline Chelicerata: Arachnida & 4 & Insecta: Chaoboridae & 6 \\
\hline Crustacea: Cladocera & 5 & Insecta: Simuliidae & 6 \\
\hline Crustacea: Ostracoda & 5 & Insecta: Ceratopogonidae & 6 \\
\hline Crustacea: Copepoda & 3 & Insecta: Chironominae & 8 \\
\hline Insecta: Ephemeroptera & 4 & Insecta: GoeldiChironomus & 6 \\
\hline Insecta: Plecoptera & 1 & Insecta: Tanypodinae & 8 \\
\hline Insecta: Trichoptera & 3 & Insecta: Orthocladiinae & 8 \\
\hline Insecta: Odonata & 5 & Insecta: Brachycera & 6 \\
\hline
\end{tabular}

Valores de IBF podem variar de 0 a 10, onde valores próximos de 10 indicam comunidades dominadas por organismos tolerantes à poluição orgânica e valores próximos de 0 indicam comunidades onde organismos intolerantes a poluição predominam, ou seja, quanto mais próxima de 0 , melhor a qualidade ambiental do ambiente aquático. A Tabela 35 , a seguir, mostra a classificação da qualidade da água segundo o Índice. 
Tabela 35 - Qualidade da água segundo o Índice Biótico de Famílias de Hilsenhoff. Fonte: Ferreiro (2007).

\begin{tabular}{|c|c|c|}
\hline Índice biótico & Qualidade da água & Grau de poluição orgânica \\
\hline $0,00-3,50$ & Excelente & Sem poluição orgânica aparente \\
\hline $3,51-4,50$ & Muito boa & Possível poluição orgânica leve \\
\hline $4,51-5,50$ & Boa & Alguma poluição orgânica \\
\hline $5,51-6,50$ & Razoável & Poluição orgânica razoável \\
\hline $6,51-7,50$ & Moderadamente pobre & Poluição orgânica significativa \\
\hline $7,51-8,50$ & Pobre & Poluição orgânica muito significativa \\
\hline $8,51-10,00$ & Muito pobre & Poluição orgânica severa \\
\hline
\end{tabular}

\subsubsection{6 Índice EPT (Ephemeroptera, Plecoptera e Trichoptera)}

O índice de EPT (quantidade de organismos sensíveis à poluição, das ordens Ephemeroptera, Plecoptera e Trichoptera). Segundo Moretti (2004), Ephemeroptera, Plecoptera e Trichoptera são organismos característicos de águas correntes, limpas e bem oxigenadas, portanto os organismos destas ordens têm como característica principal a sensibilidades a baixos níveis de poluição, desta forma em ambientes aquáticos impactados ocorre a extinção local destes indivíduos e predomínio de outros mais resistentes. Portanto, são bons indicadores da qualidade ambiental, uma vez que sua presença indica que o ambiente não está impactado ou que está pouco impactado. A seguir são descritas as principais características destas ordens.

\section{a) Ordem Ephemeroptera}

A ordem de Insetos Ephemeroptera possui aproximadamente 2500 espécies, distribuídas por 23 famílias. São animais de vida curta, que levam o nome de efêmera devido ao fato de o adulto viver apenas poucas horas, sem se alimentar, apenas se dedicando à reprodução e à postura dos ovos para manutenção da geração seguinte. Possuem corpos longos e moles podendo atingir até quatro $\mathrm{cm}$ de comprimento. Suas asas são membranosas com numerosas veias, sendo as asas posteriores menores que as anteriores. As ninfas das efêmeras vivem na água, em geral escondidas sobre rochas. São os únicos insetos que sofrem muda após terem adquirido asas funcionais. (RUPPERT, 1996).

As efeméridas apresentam antenas pequenas, olhos compostos bem desenvolvidos e três longos filamentos no abdome quando adultas caracterizam-se 
por peças bucais atrofiadas e um sistema digestivo não funcional, enquanto que as ninfas possuem peças bucais do tipo mastigadoras pertencendo ao grupo trófico dos coletores e raspadores, sendo os representantes dessa ordem geralmente herbívoros podendo raspar ou filtrar seu alimento, sendo que espécies de alguns gêneros apresentam hábitos carnívoros. As efêmeras habitam corpos de água doce parada ou de curso lento, assim estes organismos são importantes nas cadeias alimentares por servirem de alimento para muitos peixes, possuindo assim um importante papel ecológico (CALLISTO et al., 2001). Graças à sua sensibilidade às condições físico-químicas do meio, as efêmeras são um dos grupos mais utilizados em programas de biomonitoramento de qualidade da água (FERNANDEZ et al., 2006). A llustração 63 a seguir mostra o esquema geral e uma fotografia de uma ninfa de Ephemeroptera.

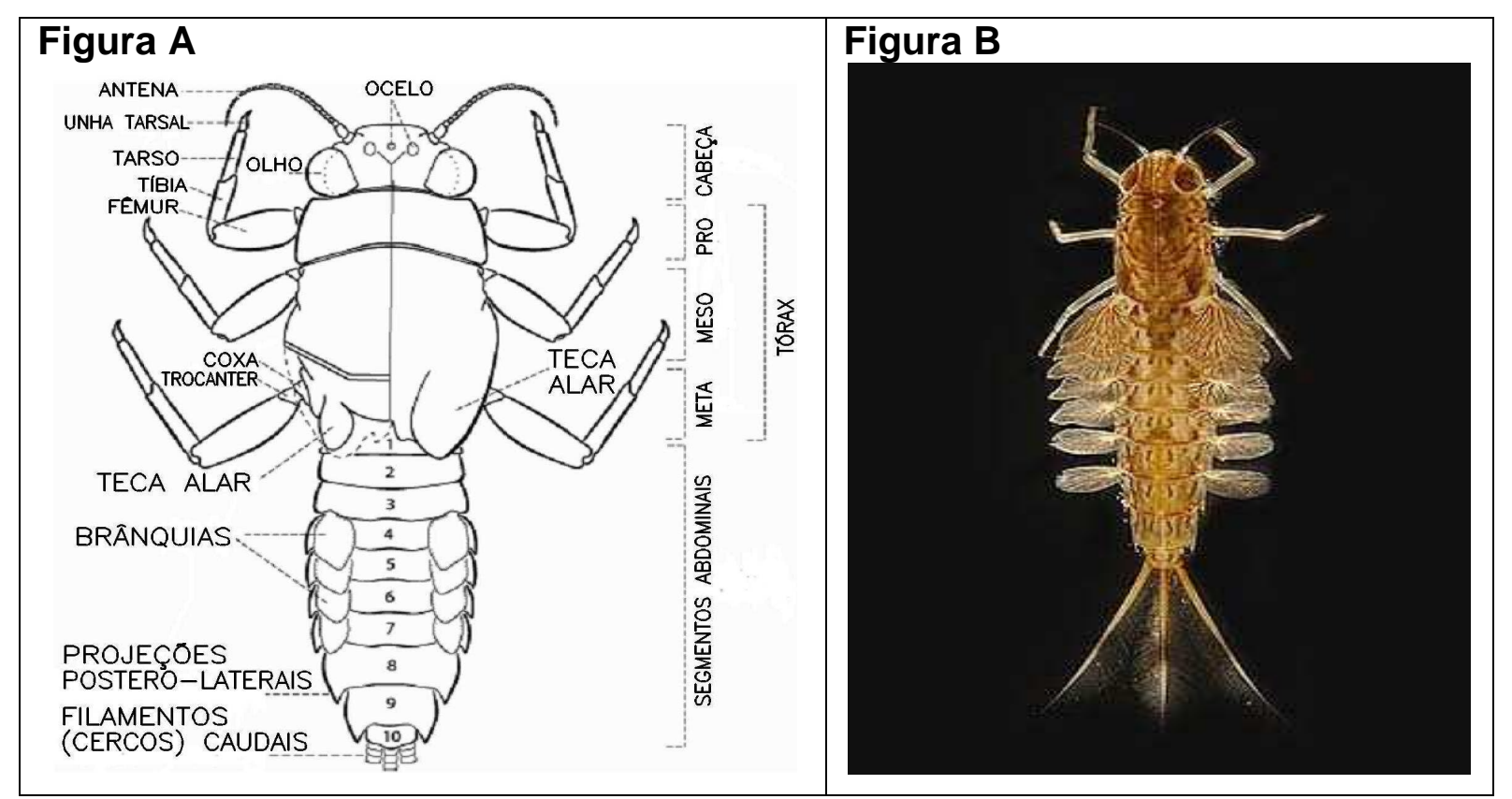

Ilustração 63 - Figura A: Esquema da vista dorsal de uma ninfa de Ephemeroptera - Fonte: Modificada de Mariano/ Froehlich (2007) e Figura B: Foto de uma ninfa de Ephemeroptera - Fonte: Clickciência (2009).

b) Ordem Plecoptera

Os Plecoptera são uma ordem de insetos aquáticos, com pouco mais de 2 mil espécies descritas. Sua distribuição se dá por todo o mundo, exceto em regiões de baixas temperaturas e alta altitude. Habitam a vegetação próxima dos corpos d'água e em cascas soltas de árvores, confundindo-se bem com o substrato, além disso, não são bons voadores, mas podem se deslocar rapidamente no solo. Podem 
ser encontrados ao amanhecer ou durante dias nublados conforme emergem de rochas projetadas de riachos, ou na folhagem marginal de rios e riachos (COSTA et al., 2006). A llustração 64 a seguir mostra o esquema geral e uma fotografia de uma ninfa de Plecoptera.

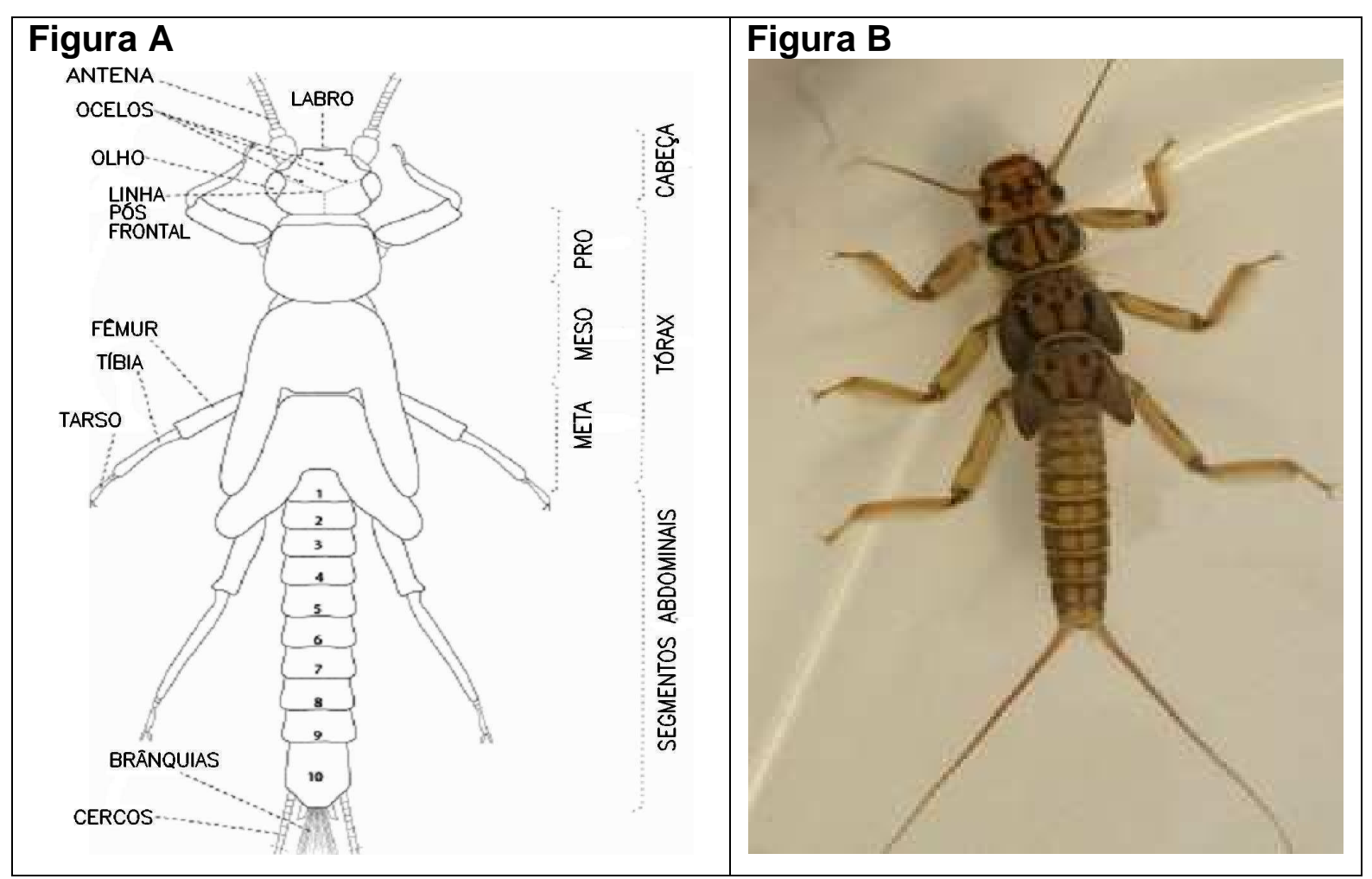

Ilustração 64 - Figura A: Esquema Geral de uma ninfa de Plecoptera - Fonte: Modificada de Lecci et al. (2007) e Figura B: Ninfa de Plecoptera - Fonte: Böhringer, Friedrich.

No estágio de ninfa seu comprimento varia de 4 a $50 \mathrm{~mm}$, possui cabeça prognata, porta um par de olhos compostos bem desenvolvidos, com três, raramente dois, ocelos, suas antenas são longas, filiformes com 30 a 80 segmentos e seu aparelho bucal é do tipo mastigador, porém em algumas espécies ele é vestigial. Seus três pares de pernas são cursoriais. Os adultos da maioria das espécies são alados, algumas espécies são braquípteras (com asas curtas) e outras ápteras (sem asas). Quando presentes, os dois pares de asas são similares, ambas são membranosas, sendo as asas posteriores maiores que as anteriores. Quando dobradas (em repouso), as asas projetam-se além do final do abdome. Os imaturos são similares aos adultos, exceto por não possuírem asas e genitália desenvolvidas (RUPPERT, 1996). 
A alimentação dos adultos se baseia em algas verdes, líquen, madeira em decomposição, diatomáceas e detritos de origem vegetal, já a dieta dos estágios imaturos varia de grupo para grupo, o que é refletido pelo aparelho bucal de cada um, podendo ser detritívoros, herbívoros, carnívoros e onívoros. Não há predadores conhecidos especializados em Plecoptera. As formas imaturas são comidas por peixes, formas imaturas de Odonata, besouros aquáticos, Trichoptera e mesmo outros Plecoptera (CALLISTO et al., 2001).

c) Ordem Trichoptera

A maior parte das larvas de Trichoptera vive em água fria, corrente e bem oxigenada, algumas espécies vivem em águas paradas, essas espécies vivem debaixo de pedras, troncos e materiais vegetais e são indicadoras de águas oligotróficas. Os representantes desta ordem pertencem aos grupos tróficos dos coletores, carnívoros ou fragmentadores, grande parte de suas larvas alimentam-se de algas verdes, liquens, madeira em decomposição, diatomáceas e detritos de origem vegetal e animal, mas há também algumas espécies que são predadoras. Os Trichoptera desempenham importante papel ecológico por servirem de alimento para muitos peixes e outros animais aquáticos (COSTA et al., 2006). A llustração 65 a seguir mostra o esquema geral e uma fotografia de uma Larva de Trichoptera.

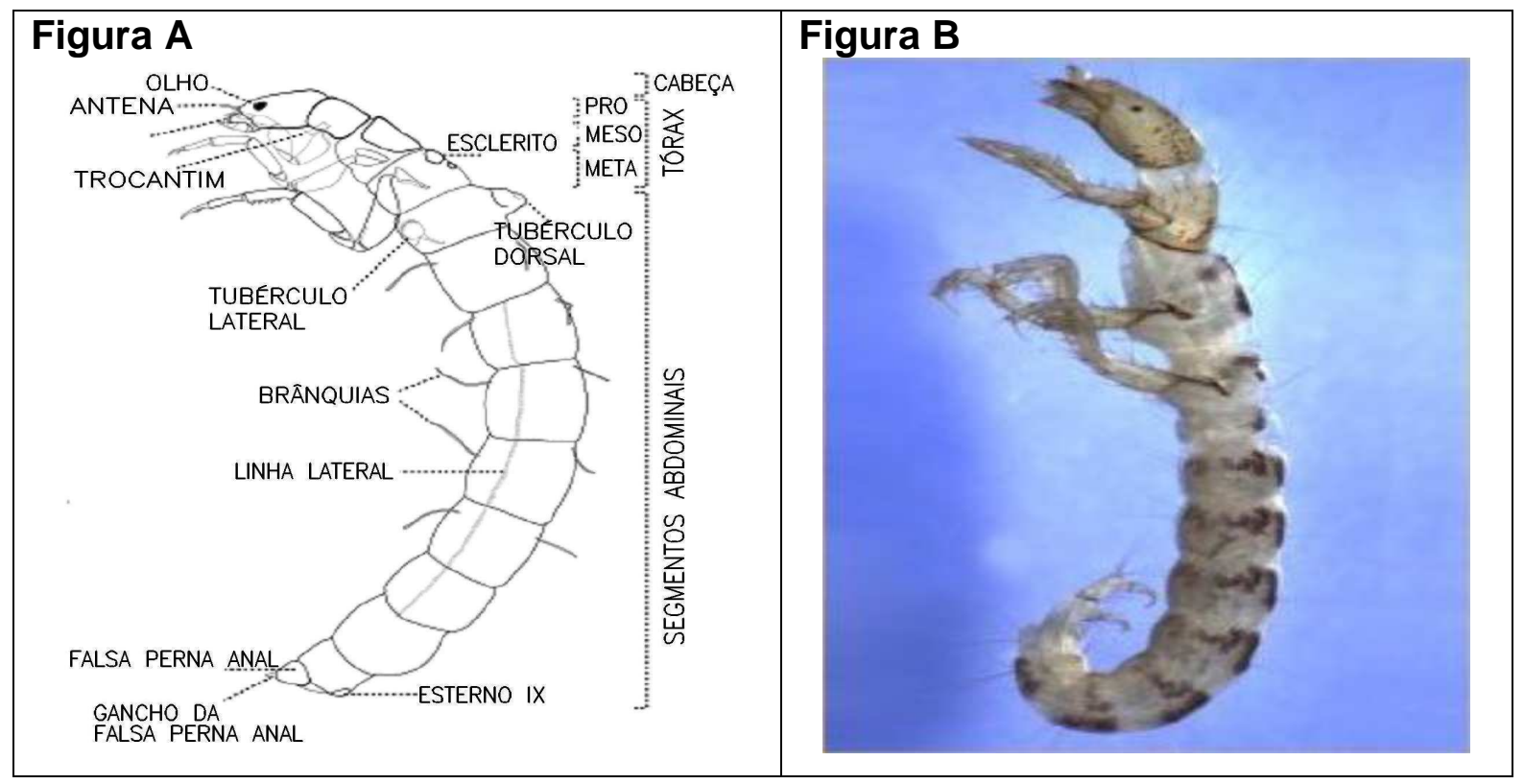

llustração 65 - Figura A: Esquema Geral de uma Larva de Trichoptera - Fonte: Modificada de Calor (2007) e Figura B: Foto de Larva de Trichoptera - Fonte: USEPA (s/d). 


\subsubsection{Resultados e discussões}

\subsubsection{Comunidade bentônica: Nascente do Sapé}

As armadilhas foram instaladas no dia 14/03/2012 e monitoradas durante três semanas, no entanto, na segunda semana de monitoramento a armadilha do ponto mediano desapareceu e em visita à área no dia 07/04/2012 foi constatada a mudança brusca na qualidade da água do corpo, que apresentava cor acinzentada e turbidez elevada, o que inviabilizou a utilização das armadilhas para coleta dos indicadores biológicos, uma vez que a análise seria prejudicada. Tal avaliação não foi repetida em função da instabilidade na qualidade da água do corpo d'água, portanto optou-se por prosseguir com a avaliação biológica somente no Córrego Ibiraporã.

\subsubsection{Comunidade bentônica: Córrego Ibiraporã}

A Tabela 36 e a Tabela 37, a seguir, mostram a distribuição quantitativa dos organismos nas amostras em cada ponto e nos diferentes períodos de coleta. A llustração 66 mostra fotos de alguns organismos encontrados nas amostras durante a triagem. 
Tabela 36 - Abundância dos organismos bentônicos - Inverno. Fonte: Elaborado pela autora.

\begin{tabular}{|c|c|c|c|c|c|c|c|c|c|c|c|c|c|c|c|c|c|c|c|c|}
\hline \multirow{3}{*}{ Filo } & \multirow{3}{*}{ Classe } & \multirow{3}{*}{ Taxon mais especifico } & \multicolumn{9}{|c|}{ Comunidade Bentônica: Inverno } & \multicolumn{9}{|c|}{ Comunidade Bentônica: Inverno } \\
\hline & & & \multicolumn{9}{|c|}{ Ponto 01 - Rua Joaquim Maciel n80 } & \multicolumn{9}{|c|}{ Ponto 02 - Rua Ibiraporã № 272} \\
\hline & & & A1 & A2 & A3 & A4 & A5 & A6 & A7 & A8 & $\Sigma$ & A9 & A10 & A11 & A12 & A13 & A14 & A15 & A16 & $\Sigma$ \\
\hline Nematoda & Nematoda & Gordiidae & 97 & 313 & 41 & 257 & 43 & 31 & 387 & 278 & 1169 & 183 & 152 & 70 & 63 & 87 & 105 & 40 & 50 & 750 \\
\hline Annelida & Oligochaeta & Naididae & 75 & 321 & 37 & 172 & 27 & 17 & 371 & 311 & 1020 & 27 & 27 & 68 & 41 & 50 & 87 & 5 & 3 & 308 \\
\hline Annelida & Hirudinea & Hirudinea & 1 & 1 & 0 & 1 & 0 & 0 & 1 & 2 & 4 & 0 & 0 & 0 & 0 & 0 & 0 & 0 & 0 & 0 \\
\hline Annelida & Hirudinea & Hirudinea & 3 & 1 & 1 & 0 & 0 & 0 & 2 & 0 & 7 & 2 & 4 & 10 & 10 & 1 & 1 & 6 & 7 & 41 \\
\hline Mullusca & Gatropoda & Amnicola & 180 & 283 & 20 & 99 & 28 & 18 & 87 & 57 & 715 & 7 & 15 & 30 & 40 & 8 & 11 & 10 & 13 & 134 \\
\hline Mullusca & Bivalvia & Sphaeriidae & 0 & 0 & 0 & 0 & 0 & 0 & 0 & 0 & 0 & 1 & 5 & 50 & 10 & 1 & 0 & 4 & 5 & 76 \\
\hline Arthropoda & Arachnida & Acarina & 0 & 0 & 0 & 0 & 0 & 0 & 0 & 0 & 0 & 0 & 0 & 0 & 0 & 0 & 0 & 0 & 0 & 0 \\
\hline Arthropoda & Ara chnida & Oribatida & 8 & 0 & 1 & 13 & 1 & 0 & 0 & 1 & 23 & 0 & 0 & 0 & 0 & 0 & 0 & 0 & 0 & 0 \\
\hline Arthropoda & Arachnida & Halacarina & 5 & 13 & 1 & 7 & 2 & 1 & 8 & 7 & 37 & 0 & 0 & 0 & 0 & 0 & 0 & 0 & 0 & 0 \\
\hline Arthropoda & Os tra coda & Os tra coda & 65 & 111 & 5 & 48 & 15 & 7 & 45 & 61 & 296 & 0 & 2 & 0 & 0 & 2 & 4 & 1 & 3 & 12 \\
\hline Arthropoda & Copepoda & Copepoda & 0 & 0 & 0 & 0 & 0 & 0 & 0 & 0 & 0 & 0 & 0 & 0 & 0 & 0 & 0 & 0 & 0 & 0 \\
\hline Arthropoda & Insecta & Amelitidae & 0 & 0 & 0 & 6 & 0 & 0 & 0 & 0 & 6 & 0 & 0 & 0 & 0 & 0 & 0 & 0 & 0 & 0 \\
\hline Arthropoda & Insecta & Zygoptera & 5 & 9 & 0 & 2 & 0 & 0 & 1 & 0 & 17 & 0 & 0 & 0 & 0 & 0 & 0 & 0 & 0 & 0 \\
\hline Arthropoda & Insecta & Plecoptera & 0 & 0 & 0 & 0 & 0 & 0 & 0 & 0 & 0 & 1 & 0 & 0 & 0 & 0 & 0 & 0 & 0 & 1 \\
\hline Arthropoda & Insecta & Trichoptera & 1 & 0 & 0 & 0 & 0 & 0 & 0 & 0 & 1 & 0 & 0 & 0 & 0 & 0 & 0 & 0 & 0 & 0 \\
\hline Arthropoda & Insecta & Psephenidae & 1 & 3 & 0 & 0 & 0 & 0 & 1 & 0 & 5 & 0 & 0 & 0 & 0 & 0 & 0 & 0 & 0 & 0 \\
\hline Arthropoda & Insecta & Elmidae & 8 & 21 & 1 & 11 & 2 & 0 & 17 & 9 & 60 & 0 & 0 & 0 & 0 & 0 & 0 & 0 & 0 & 0 \\
\hline Arthropoda & Insecta & Psychodidae & 3 & 7 & 1 & 0 & 0 & 0 & 4 & 1 & 15 & 0 & 1 & 2 & 3 & 0 & 0 & 1 & 3 & 10 \\
\hline Arthropoda & Insecta & Ceratopogonidae & 8 & 15 & 2 & 7 & 0 & 1 & 5 & 7 & 38 & 1 & 0 & 2 & 4 & 0 & 3 & 0 & 0 & 55 \\
\hline Arthropoda & Insecta & Tipulidae & 1 & 5 & 1 & 0 & 2 & 0 & 7 & 0 & 16 & 0 & 0 & 0 & 0 & 0 & 0 & 0 & 0 & 0 \\
\hline Arthropoda & Insecta & Chironomidae & 2446 & 5496 & 990 & 2455 & 727 & 401 & 3919 & 4317 & 16434 & 114 & 102 & 982 & 243 & 1105 & 1269 & 891 & 840 & 5546 \\
\hline & & $\Sigma$ & 2907 & 6599 & 1101 & 3078 & 847 & 476 & 4855 & 5051 & 19863 & 336 & 308 & 1214 & 414 & 1254 & 1480 & 958 & 924 & 6933 \\
\hline
\end{tabular}


Tabela 37 - Abundância dos organismos bentônicos - Verão. Fonte: Elaborado pela autora.

\begin{tabular}{|c|c|c|c|c|c|c|c|c|c|c|c|c|c|c|c|c|c|c|c|c|}
\hline \multirow{3}{*}{ Filo } & \multirow{3}{*}{ Classe } & \multirow{3}{*}{ Taxon mais especifico } & \multicolumn{9}{|c|}{ Comunidade Bentônica: Verão } & \multicolumn{9}{|c|}{ Comunidade Bentônica: Verão } \\
\hline & & & \multicolumn{9}{|c|}{ Ponto 01 - Rua Joaquim Maciel n80 } & \multicolumn{9}{|c|}{ Ponto 02 - Em Frente № 272} \\
\hline & & & A17 & A18 & A19 & A20 & A21 & A22 & A23 & A24 & $\Sigma$ & A25 & A26 & A27 & A28 & A29 & A30 & A31 & A32 & $\Sigma$ \\
\hline Nematoda & Nematoda & Gordiidae & 51 & 38 & 52 & 59 & 48 & 40 & 35 & 79 & 402 & 47 & 38 & 41 & 37 & 49 & 45 & 51 & 48 & 356 \\
\hline Annelida & Oligochaeta & Naididae & 42 & 29 & 47 & 76 & 39 & 37 & 39 & 51 & 360 & 11 & 9 & 13 & 15 & 17 & 8 & 9 & 17 & 99 \\
\hline Annelida & Hirudinea & Hirudinea & 0 & 0 & 0 & 0 & 0 & 0 & 0 & 0 & 0 & 0 & 0 & 0 & 0 & 0 & 0 & 0 & 0 & 0 \\
\hline Annelida & Hirudinea & Hirudinea & 13 & 17 & 8 & 9 & 10 & 7 & 14 & 13 & 91 & 0 & 0 & 0 & 0 & 0 & 0 & 0 & 0 & 0 \\
\hline Mullusca & Gatropoda & Amnicola & 19 & 22 & 27 & 15 & 33 & 10 & 25 & 37 & 188 & 0 & 1 & 0 & 0 & 0 & 0 & 0 & 0 & 1 \\
\hline Mullusca & Bivalvia & Sphaeriidae & 1 & 0 & 2 & 4 & 0 & 0 & 1 & 2 & 10 & 0 & 0 & 0 & 0 & 0 & 0 & 0 & 0 & 0 \\
\hline Arthropoda & Arachnida & Acarina & 0 & 0 & 0 & 0 & 0 & 0 & 0 & 0 & 0 & 0 & 0 & 0 & 0 & 0 & 0 & 0 & 0 & 0 \\
\hline Arthropoda & Arachnida & Oribatida & 0 & 0 & 0 & 0 & 0 & 0 & 0 & 0 & 0 & 0 & 0 & 0 & 0 & 0 & 0 & 0 & 0 & 0 \\
\hline Arthropoda & Arachnida & Halacarina & 0 & 0 & 0 & 0 & 0 & 0 & 0 & 0 & 0 & 0 & 0 & 0 & 0 & 0 & 0 & 0 & 0 & 0 \\
\hline Arthropoda & Os tracoda & Os tra coda & 0 & 0 & 0 & 0 & 0 & 0 & 0 & 0 & 0 & 0 & 0 & 0 & 0 & 0 & 0 & 0 & 0 & 0 \\
\hline Arthropoda & Copepoda & Copepoda & 0 & 0 & 0 & 0 & 0 & 0 & 0 & 0 & 0 & 1 & 0 & 0 & 0 & 0 & 0 & 0 & 0 & 1 \\
\hline Arthropoda & Insecta & Amelitidae & 0 & 0 & 0 & 0 & 0 & 0 & 0 & 0 & 0 & 0 & 0 & 0 & 0 & 0 & 0 & 0 & 0 & 0 \\
\hline Arthropoda & Insecta & Zygoptera & 0 & 0 & 0 & 0 & 0 & 0 & 0 & 0 & 0 & 0 & 0 & 0 & 0 & 0 & 0 & 0 & 0 & 0 \\
\hline Arthropoda & Insecta & Plecoptera & 0 & 0 & 0 & 0 & 0 & 0 & 0 & 0 & 0 & 0 & 0 & 0 & 0 & 0 & 0 & 0 & 0 & 0 \\
\hline Arthropoda & Insecta & Trichoptera & 0 & 0 & 0 & 0 & 0 & 0 & 0 & 0 & 0 & 0 & 0 & 0 & 0 & 0 & 0 & 0 & 0 & 0 \\
\hline Arthropoda & Insecta & Psephenidae & 0 & 0 & 0 & 0 & 0 & 0 & 0 & 0 & 0 & 0 & 0 & 0 & 0 & 0 & 0 & 0 & 0 & 0 \\
\hline Arthropoda & Insecta & Elmidae & 0 & 0 & 0 & 0 & 0 & 0 & 0 & 0 & 0 & 0 & 0 & 0 & 0 & 0 & 0 & 0 & 0 & 0 \\
\hline Arthropoda & Insecta & Psychodidae & 5 & 1 & 3 & 0 & 4 & 5 & 10 & 7 & 35 & 0 & 0 & 0 & 1 & 0 & 1 & 0 & 0 & 2 \\
\hline Arthropoda & Insecta & Ceratopogonidae & 0 & 0 & 1 & 0 & 0 & 2 & 0 & 0 & 58 & 0 & 2 & 0 & 0 & 3 & 1 & 0 & 0 & 64 \\
\hline Arthropoda & Insecta & Tipulidae & 0 & 0 & 0 & 0 & 0 & 0 & 0 & 0 & 0 & 0 & 0 & 0 & 0 & 0 & 1 & 1 & 0 & 2 \\
\hline Arthropoda & Insecta & Chironomidae & 275 & 245 & 214 & 197 & 170 & 242 & 224 & 273 & 1840 & 116 & 107 & 155 & 131 & 173 & 181 & 215 & 242 & 1320 \\
\hline & & $\Sigma$ & 406 & 352 & 354 & 360 & 304 & 343 & 348 & 462 & 2984 & 175 & 157 & 209 & 184 & 242 & 237 & 276 & 307 & 1845 \\
\hline
\end{tabular}




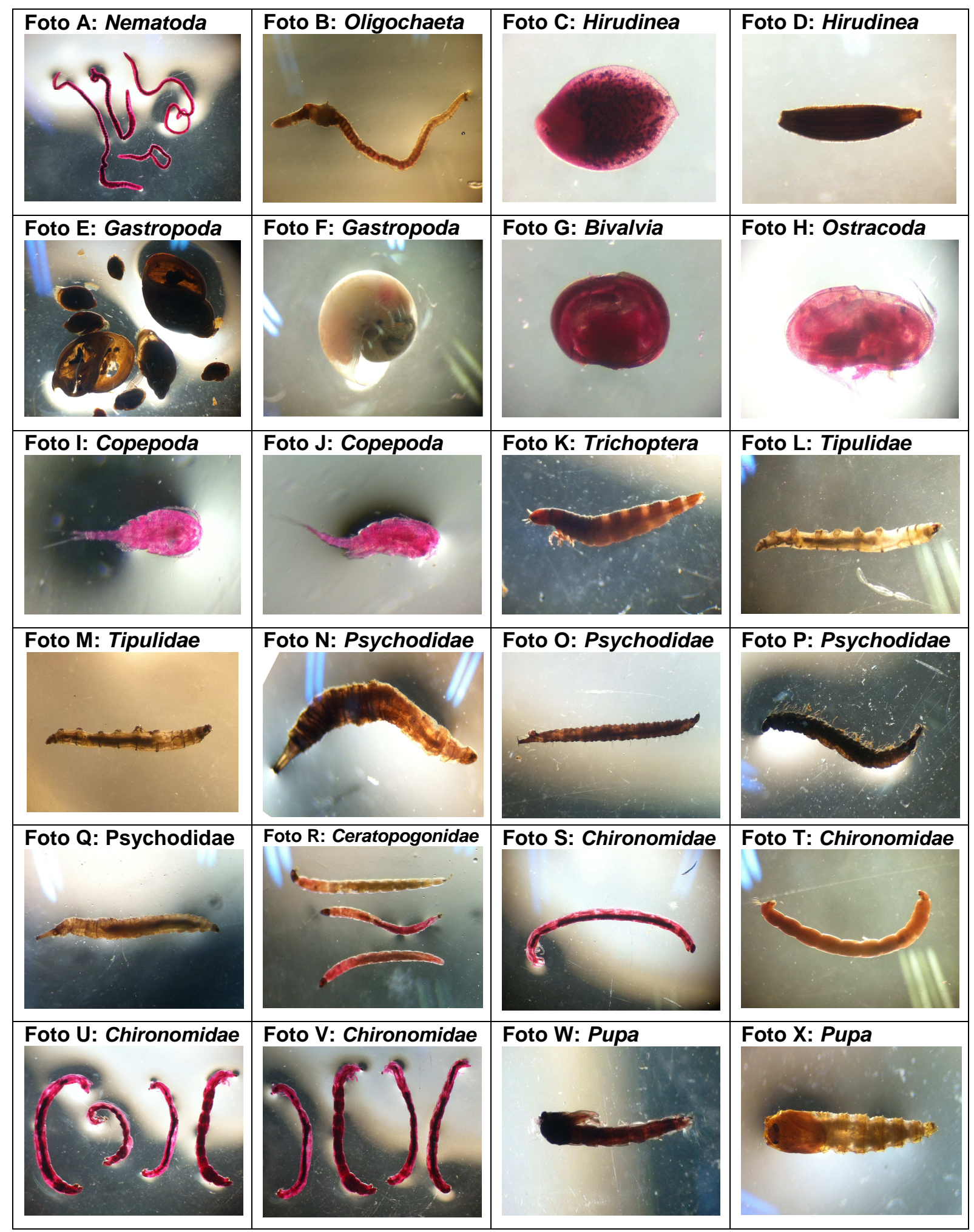

Ilustração 66 - Organismos presentes nas amostras. Fonte: Fotos da autora.

Os itens seguintes mostram os resultados obtidos através da utilização dos Índices de Diversidade Biológica, Riqueza Biológica, Equitabilidade Biológica, Dominância Biológica, Biótico de Famílias de Hilsenhoff e EPT. 


\subsubsection{1 Índices DiB, RB, EB e DoB: Córrego lbiraporã}

A Tabela 38 apresenta os resultados obtidos para: a quantificação da Diversidade Biológica através da aplicação do Índice de diversidade de ShannonWeaner; a quantificação da Riqueza Biológica através da somatória dos táxons presentes em cada amostra; a quantificação da Equitabilidade Biológica através da aplicação do Índice de Pielou; e para a quantificação da Dominância Biológica através da aplicação do Índice de Simpson.

Tabela 38 - Resultados obtidos - Índices Biológicos: Córrego Ibiraporã. Fonte: Elaborado pela autora.

\begin{tabular}{|c|c|c|c|c|}
\hline $\begin{array}{c}\text { Diversidade } \boldsymbol{H}^{\prime} \\
\text { (Shannon-Weaner) }\end{array}$ & Ponto 1 - Inverno & Ponto 2 - Inverno & Ponto 1 - Verão & Ponto 2 - Verão \\
\cline { 2 - 5 } & 9,89 & 8,84 & 7,98 & 7,51 \\
\hline \hline \multirow{2}{*}{ Riqueza } & Ponto 1 - Inverno & Ponto 2 - Inverno & Ponto 1 - Verão & Ponto 2 - Verão \\
\cline { 2 - 5 } & 19 & 12 & 10 & 8 \\
\hline \hline $\begin{array}{c}\text { Equitabilidade J' } \\
\text { (índice de Pielou) }\end{array}$ & Ponto 1 - Inverno & Ponto 2 - Inverno & Ponto 1 - Verão & Ponto 2 - Verão \\
\cline { 2 - 5 } & 1,00 & 0,89 & 0,81 & 0,76 \\
\hline $\begin{array}{c}\text { Dominância C } \\
\text { (Índice de Simpson) }\end{array}$ & Ponto 1 - Inverno & Ponto 2 - Inverno & Ponto 1 - Verão & Ponto 2 - Verão \\
\cline { 2 - 5 } & 0,52 & 0,56 & 0,72 & 0,45 \\
\hline
\end{tabular}

Temos para o Índice de diversidade de Shannon-Weaner que quanto maior o H' obtido, mais diversa é a comunidade; para o índice de Riqueza que quanto maior o valor obtido, mais rica é a comunidade; e para o índice de Equitabilidade de Pielou que quanto maior o J' obtido, maior o equilíbrio da distribuição dos organismos na amostra. Decréscimos nos valores dos índices de Diversidade, Riqueza e Equitabilidade estão relacionados com aumento de níveis de estresse ambiental no ecossistema. Aplicando esses índices para o nível de família, obteve-se como resultado que o Ponto 1 , em ambos períodos estudados, apresentou maior diversidade, riqueza e equitabilidade do que o Ponto 2. Como já foi descrito, o Ponto 1 trata-se da nascente do córrego que está em condições mais naturais se comparada às condições do Ponto 2 mais à jusante, portanto tal resultado é condizente com o esperado. Outro ponto a ser salientado é que no inverno diversidade, riqueza e equitabilidade foram maiores, tal resultado pode ser atribuído em parte ao aumento da vazão e da velocidade do corpo d'água que ocorre no verão, o que resulta em um maior potencial de arraste no fundo do canal dificultando sua colonização pelos organismos bentônicos. 


\subsubsection{2 Índice BF (Biótico de famílias de Hilsenhoff): Córrego lbiraporã}

A Tabela 39 apresenta os resultados obtidos para a quantificação do índice Biótico de Família de Hilsenhoff.

Tabela 39 - Resultados obtidos - Índice Biótico de Família de Hilsenhoff: Córrego Ibiraporã. Fonte: Elaborado pela autora.

\begin{tabular}{|c|c|c|c|c|}
\hline \multirow{2}{*}{$\begin{array}{c}\text { Biótico de Famílias } \\
\text { de Hilsenhoff (IBF) }\end{array}$} & Ponto 1 - Inverno & Ponto 2 - Inverno & Ponto 1 - Verão & Ponto 2 - Verão \\
\cline { 2 - 5 } & 8,01 & 8,11 & 8,02 & 8,10 \\
\cline { 2 - 5 } & Pobre & Pobre & Pobre & Pobre \\
\hline
\end{tabular}

Segundo a classificação da qualidade da água pelo índice Biótico de Família de Hilsenhoff, valores obtidos com a aplicação do índice entre 7,51 e 8,5 são classificados como "Pobre", indicando que ainda há forte influência de poluição orgânica no corpo d'água. Tal resultado é condizente com o esperado, uma vez que os organismos presentes no corpo d'água são capazes de acumular respostas referentes a impactos provocados em momentos anteriores ao da coleta e estando o corpo d'água em um estante anterior sobre forte influência de lançamentos de efluentes, mesmo que estes lançamentos tenham sido subtraídos do corpo d'água, os organismos ainda refletem o evento.

\subsubsection{3 Índice EPT (Ephemeroptera, Plecoptera e Trichoptera): Córrego Ibiraporã}

Organismos das ordens Ephemeroptera, Plecoptera e Trichoptera são sensíveis a alterações no meio, portanto sua presença é um indicativo de que o meio está em equilíbrio e sua ausência, por sua vez, indica que o ambiente esta em desequilíbrio. Somente foram encontrados 2 representantes destas ordens nas amostras coletadas no verão, um trichoptera na amostra 1 do ponto 1 e um Plecoptera na amostra 9 do ponto 2 (Tabela 36). Apesar de estes organismos estarem presentes nas amostras, estão presentes em baixa quantidade, portanto não pode-se considerar o ambiente em equilíbrio

\subsection{Avaliação física e química $x$ biológica}

Obteve-se com a aplicação da classificação realizada pelo programa "Córrego Limpo" segundo a DBO (Tabela 09) que o corpo d'água ficou entre a 
classificação "Condições Boas" e "Condições Naturais". Já com a classificação segundo o Índice de Família de Hilsenhoff, os pontos analisados foram classificados como "Pobre". A llustração 67 apresenta os resultados obtidos para as coletas analisadas e suas respectivas classificações segundo sua DBO, já a llustração 68 apresenta os resultados obtidos segundo a classificação através do Índice de Família de Hilsenhoff.

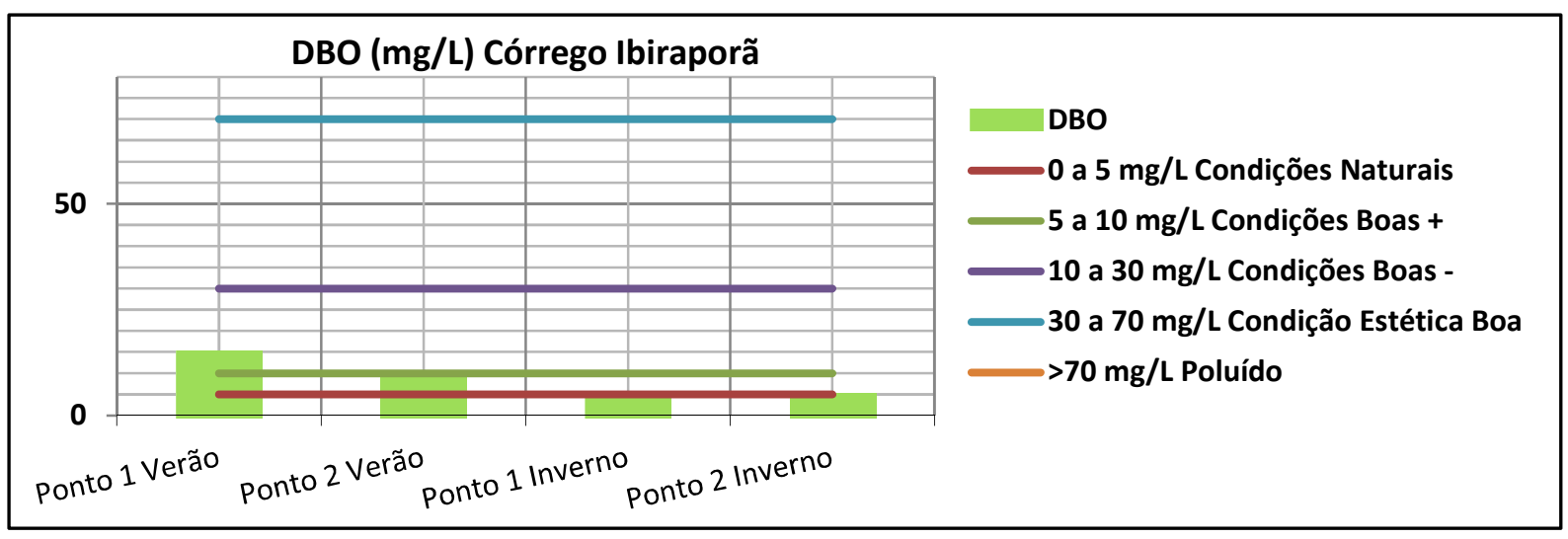

llustração 67 - DBO do Córrego Ibiraporã e sua classificação segundo "Córrego Limpo". Fonte: Elaborado pela autora.

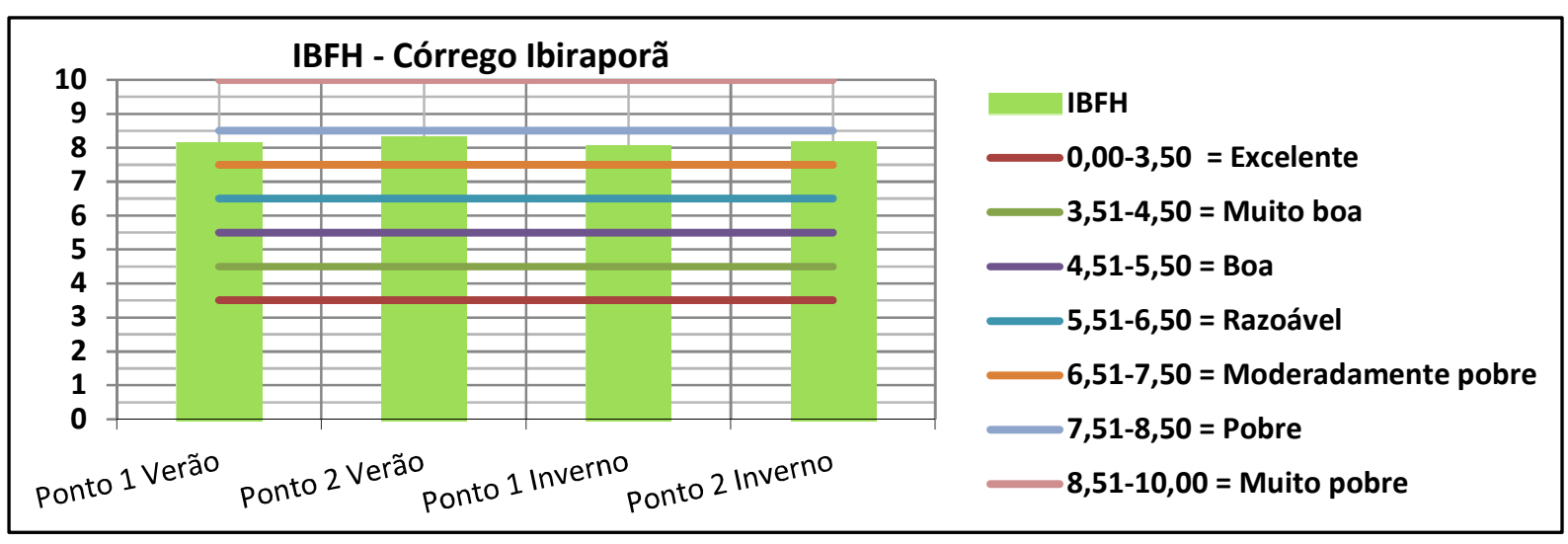

Ilustração 68 - DBO do Córrego Ibiraporã e sua classificação segundo Índice Biótico de Família de Hilsenhoff. Fonte: Elaborado pela autora.

Observou se no estudo as diferenças obtidas na classificação da qualidade do corpo d'água através da utilização dos dois métodos. Pode-se afirmar que indicadores físicos e químicos apresentam resposta instantânea, enquanto os indicados biológicos tem resposta cumulativa. Portanto, fica clara a importância do uso conjunto de indicadores biológicos e indicadores físicos e químicos como ferramenta de avaliação da qualidade de corpos d'água. 


\subsubsection{Evolução da qualidade de corpos d'água em áreas urbanas}

Aplicando a ecossistemas aquáticos continentais, especificamente rios e riachos, os conceitos de habitat e diversidade e com base nos resultados obtidos pode se descrever a seguinte sequência de fases percorridas por um corpo d'água em áreas urbanas:

1 Fase: Em um primeiro momento, temos o corpo d'água em estado dito natural, ou seja, antes de sofrer qualquer intervenção antrópica. Neste estágio o corpo d'água apresenta uma determinada biota que sofre variações populacionais em função de eventos sazonais como mudanças ao longo do ano na intensidade luminosa, regime de chuvas (alterando sua vazão), temperatura, entre outros fatores. No entanto, a biota estabelecida no corpo d'água está apta a lidar com tais alterações, de modo que apesar da flutuação populacional ao longo do ano, ela se mantém constante se avaliada uma escala temporal mais ampla. Em um ambiente dito natural como este há uma grande possibilidade de habitats que se consolidaram durante a história evolutiva deste ambiente atingindo um equilíbrio próprio e interdependente.

2ำ Fase: Em segundo momento, com a intervenção do homem, que geralmente envolve a alteração na geometria deste corpo d'água, mudanças no aporte de sedimentos provocado pela mudança no uso do solo e lançamento de efluentes, há uma mudança drástica nos habitats existentes no momento anterior, uma vez que há a inserção de outros fatores para os quais alguns organismos que ali habitavam não eram tolerantes. Assim, os organismos sensíveis às novas condições são levados à extinção local e o que resta são organismos tolerantes às novas condições. Entende se então que estes eventos levam rapidamente à perda da diversidade existente, através da extinção local de espécies mais sensíveis e por estarem associados à produção de habitats mais restritivos, há a criação de um ecossistema onde há a predominância de organismos resistentes. Um forte componente de remodelagem desse ecossistema é a quantidade de matéria orgânica disponível, já que micro-organismos decompositores se proliferam na sua presença, consumindo o oxigênio disponível na água e como a quantidade de oxigênio é fator limitante à maioria dos organismos complexos como animais e vegetais em qualquer ambiente, a limitação deste recurso molda significativamente $o$ 
ecossistema. Os corpos d'água em áreas urbanas em sua grande maioria encontram se estagnados neste estágio.

3ํㅡ Fase: Em um terceiro momento, com a retirada das fontes de matéria orgânica, preponderantemente esgotos sanitários, através da consolidação do saneamento na bacia, o corpo d'água tende a reestabelecer sua oxigenação devido à redução da influência de micro-organismos decompositores, assim, com o aumento da disponibilidade do recurso oxigênio há o aumento da riqueza de organismos complexos mais basais, filogeneticamente, como insetos aquáticos ou na sua fase de vida aquática e macrófitas aquáticas, organismos que em ambientes aquáticos ditos naturais dão sustentação à existência de organismos mais derivados, como peixes. Nesta fase, a carga advinda do escoamento superficial tem influência significativa no corpo d'água, uma vez que além do aporte de matéria orgânica ela pode contribuir com outros elementos que por ventura podem gerar outros fatores limitantes.

4ำ Fase: Por fim, em um quarto momento, com a eliminação das cargas pontuais e controle da carga difusa, temos um corpo d'água que suporta a existência de animais mais derivados, como algumas espécies de peixes mais resistentes. Este corpo d'água integrado à paisagem urbana tem importante papel na promoção do bem estar da população e no aumento da sua qualidade de vida. 


\section{CONCLUSÃO}

Através da revisão bibliográfica foi possível conhecer a evolução do processo de recuperação dos corpos d'água no Brasil e no mundo, bem como os principais entraves do processo, conhecendo também os principais programas de despoluição em andamento no Brasil e a forma de atuação de cada um deles. Além disso, foi possível se aprofundar nos aspectos particulares que envolvem as fontes geradoras de poluição para os corpos d'água, as cargas pontuais e difusas, e conhecer melhor as formas de quantifica-las e também de avaliar os impactos que estas causam sobre os corpos d'água, através do uso de indicadores físicos, químicos e biológicos, ressaltando a importância do uso conjunto destes para uma melhor caracterização da qualidade do corpo d'água.

Com relação ao Córrego Ibiraporã, foi possível concluir que as medidas para promoção da gestão participativa implantadas na bacia foram de extrema importância para o bom desenvolvimento do processo de despoluição do canal. Ficou claro o envolvimento da população, em especial da população residente na rua do canal, pois em todas as visitas à área foi constatada a preocupação dos moradores com o que estava sendo feito para a melhoria da qualidade do corpo d'água e também foram presenciadas diversas denuncias de novas ligações de esgotos clandestinas. Tal comportamento não passivo da população frente às ações que resultam na degradação do corpo d'água marca uma mudança de mentalidade frente à presença do corpo d'água, que outrora certamente já foi visto como fonte somente de transtornos. No entanto, há ainda uma pequena parcela da população que não se integra totalmente ao processo e acaba se tornando um entrave à completa consolidação deste, por isso é necessário acompanhamento continuo por parte do programa para que haja a efetivação por completo das ações. O início do monitoramento no Córrego Ibiraporã coincidiu com o período de conclusão das intervenções por parte do programa na bacia, o corpo d'água neste instante encontrava-se em excelentes condições; não era possível detectar ligações de esgotos e a água que fluía por ele apresentava aspecto saudável, sendo ela incolor e inodora. Já no final do monitoramento o corpo d'água começou a apresentar sinais de degradação, com o surgimento de novas ligações de esgoto clandestinas, evidenciando a necessidade da constância nas medidas não estruturais na bacia por 
parte do programa mesmo após da conclusão de suas medidas estruturais, ou seja, somente BMP's constantes na bacia podem tornar o processo de despoluição sustentável.

Já o córrego do Sapé, encontra-se em uma bacia com um potencial poluidor maior devido a falta de integração da população com o corpo d'água e também devido à proximidade com industriais que resultam em lançamentos sazonais de origem desconhecida, mas o aspecto mais interessante desta bacia é a implantação do parque linear. Estudando o processo de implantação do parque pode-se observar o quão complexa é a fase inicial dos trabalhos, pois as margens de córregos urbanos estão em sua grande maioria tomadas por moradias irregulares, portanto a implantação de um parque linear demanda a remoção desta população, que não pode ser simplesmente removida e deve sim ser remanejada. Uma solução atualmente adotada, e que tem apresentado bons resultados, é a construção de conjuntos habitacionais próximos ao parque linear implantado pra onde são remanejados aqueles que passaram pelas etapas de credenciamento realizado serviço social da prefeitura. Como vimos o processo é complexo e na maioria das vezes acaba retardando o inicio das obras civis.

Outro ponto avaliado foi à questão da metodologia utilizada para a canalização de corpos d'água, pois nas diversas saídas de campo houveram queixas quanto à dificuldade da execução da limpeza em canais cujo fundo era tratado com colchão de enrocamento, uma vez que há muita retenção de resíduos sólidos no fundo do canal e sua retirada fica limitada à intervenções manuais, uma vez que não é possível utilizar ferramentas, sendo o melhor tratamento de fundo para a realização da limpeza do canal a laje de concreto. De outro lado, realizando uma análise com um enfoque mais ambiental a laje de concreto é apresenta poucos abrigos para organismos aquáticos, o que limita a formação de uma comunidade complexa. Portanto, concluímos com base no que foi observado para os canais estudados e na referencia bibliográfica que a melhor alternativa é o tratamento do fundo com enrocamento, pois permite maior versatilidade na limpeza e também maior possibilidade de habitats para a comunidade aquática.

Através da aplicação do Teste T paramétrico para dados pareados, na série histórica de monitoramento da DBO dos córregos do programa, pode-se concluir que 
o programa é extremamente eficiente no controle de cargas pontuais, uma vez que ao eliminar as fontes de cargas pontuais, há DBO dos corpos d'água sofrem quedas drásticas, se mantendo abaixo de $20 \mathrm{mg} / \mathrm{L}$, enquanto antes das intervenções do programa apresentavam valores acima de $100 \mathrm{mg} / \mathrm{L}$. Graças ao processo de autodepuração, ou seja, através de um processo natural, há o reestabelecimento dos níveis de oxigênio no corpo d'água.

Foi possível ainda, com bases em valores de referência da DBO de diversas tipologias e do histórico do monitoramento da DBO da Nascente do Sapé, inferir a origem de lançamentos sazonais na Nascente do Sapé, ressaltando a importância do controle da carga pontual, não só como um elemento de melhoria na qualidade ambiental urbana, mas também uma ferramenta para gestão de recursos hídricos, uma vez que esta facilita a detecção de lançamentos de esgotos in natura de diversas origens nos corpos d'água. Por fim, foi possível concluir com base na análise do monitoramento da DBO que em corpos d’água como o Córrego lbiraporã, as ações de despoluição do programa "Córrego Limpo", unidas a medidas para o controle da carga difusa, poderiam resultar no atendimento da DBO de enquadramento de corpos d'água classe II ou até mesmo classe I em algumas épocas do ano, evidenciando assim a importância do controle deste tipo de poluição no meio urbano.

Com relação à avaliação física e química da água da Nascente do Sapé, os resultados obtidos para a coleta realizada indicam que o corpo d'água ainda esta sobre influência de cargas pontuais e que os pontos mais críticos são aqueles onde há menor velocidade no curso d'água e consequente menor oxigenação. Os valores "R" obtidos para os três pontos analisados, através da aplicação do Teste de Friedman para dados não paramétricos, foi condizente com a avaliação qualitativa, ou seja, a nascente $(R=32,0)$ apresenta qualidade pior que os demais pontos, possivelmente pelos motivos já expostos. Já no que se refere ao ponto 2 e 3, os valores "R" obtidos (Ponto $2, R=17,5$ e ponto $3, R=16,5$ ) foram próximos, mostrando que a qualidade da água nos dois pontos é semelhante.

Já para a avaliação física e química da água do Córrego Ibiraporã, através da análise qualitativa dos dados foi possível concluir que há um aumento significativo na concentração de poluentes no corpo d'água durante o inverno devido 
à ausência do fenômeno da diluição que ocorre no verão, resultado do aumento da precipitação sobre a bacia e consequente aumento da vazão do corpo d'água; Além disso, houve o aumento no verão das variáveis características do componente carga difusa, como óleos e graxa, alguns metais como chumbo e compostos derivados de petróleo. Realizou-se para este caso também uma segunda análise com base nos valores $\mathrm{R}$ obtidos. Conclui-se que, sendo o ponto 1 a nascente do canal, este ponto está sobre menor influência de cargas pontuais e difusas, uma vez que trata-se do trecho inicial do canal, assim havendo no inverno menos diluição da carga contida no canal, o valor $R$ obtido no inverno $(R=35,5)$ foi menor do que o valor obtido no verão $(R=39,0)$ quando o canal apresenta uma maior diluição de sua carga devido ao regime de chuvas e consequentemente está com a qualidade da água melhor. Já para o ponto 2, mais a jusante, conclui-se que, sendo os valores $\mathrm{R}$ obtidos muito parecidos para os dois períodos (Inverno, $R=43,0$ e verão, $R=42,5$ ) podemos interpretar como sendo resultado da carga difusa trazida pelo escoamento superficial, pois do contrário o corpo d'água deveria apresentar uma melhoria na qualidade de suas águas no verão devido ao efeito da diluição dos poluentes pelas chuvas constantes. Portanto, se por um lado o fator diluição é adicionado ao processo, por outro se adiciona também o fator carga difusa, desta forma tem-se a qualidade global do corpo d'água constante nos dois períodos.

No estudo, através do método da Unidade de Carga e utilizando dados de geração de carga difusa da literatura, foi possível quantificar a geração de carga difusa nas bacias da Nascente do Sapé e do Córrego Ibiraporã e obteve-se como resultado gerações semelhantes $(39,782 \mathrm{Kg} / \mathrm{km} 2 /$ dia na Nascente do Sapé e 35,986 $\mathrm{Kg} / \mathrm{km} 2 /$ dia no Córrego Ibiraporã). Portanto, como os corpos d'água apresentaram resultados distintos no processo de recuperação, pode-se atribuir estes resultados em parte ao programa de governança colaborativa implantado na bacia do Córrego Ibiraporã. Ou seja, o envolvimento da população no processo de recuperação resultou na redução do potencial poluidor da bacia resultando por fim na maior efetividade do processo de recuperação por remoção de cargas pontuais.

Com base na geração de carga difusa para cada bacia foi possível estimar a concentração de poluentes na superfície da bacia para diversos cenários, que variaram na ocorrência de precipitação, intensidade da precipitação e ocorrência de varrição. Assim concluiu-se que chuvas fortes são eficientes agentes na remoção da 
carga difusa na superfície da bacia, no entanto, o material removido vai diretamente para o corpo d'água, portanto neste cenário a qualidade do corpo d'água e da superfície da bacia são variáveis com forte correlação linear negativa. Outra conclusão possível é a de que bastam poucos dias sem precipitação para que uma bacia atinja níveis críticos de qualidade de sua superfície e que mesmo sendo baixa a eficiência da varrição, tal fator é de extrema importância para remoção da carga difusa, principalmente em períodos de estiagem.

Com relação à avaliação biológica obteve-se como resultado para o Índice de diversidade de Shannon-Weaner, de Riqueza e de Equitabilidade de Pielou, aplicados para o nível de família, que o Ponto 1, em ambos períodos estudados, apresentou maior diversidade, riqueza e equitabilidade do que o Ponto 2. Tratandose o Ponto 1 da nascente do córrego que está em condições mais naturais se comparada às condições do Ponto 2 mais à jusante, conclui-se que tal resultado é condizente com o esperado. Outro ponto a ser salientado é que no inverno diversidade, riqueza e equitabilidade foram maiores, tal resultado pode ser atribuído em parte ao aumento da vazão e da velocidade do corpo d'água que ocorre no verão, o que resulta em um maior potencial de arraste no fundo do canal dificultando sua colonização pelos organismos bentônicos.

Aplicou-se também o índice BFH (Biótico de Família de Hilsenhoff) e obtiveram-se valores entre 7,51 e 8,5 para todos os conjuntos amostrais estudados, enquadrando o corpo d'água na classificação "Pobre", o que indica que ainda há forte influência de poluição orgânica no corpo d'água. Tal resultado é condizente com o esperado, uma vez que os organismos presentes no corpo d'água são capazes de acumular respostas referentes a impactos provocados em momentos anteriores ao da coleta e estando o corpo d'água em um estante anterior sobre forte influência de lançamentos de efluentes, mesmo que estes lançamentos tenham sido subtraídos do corpo d'água, os organismos ainda refletem o evento. Corroborando então a eficiência do indicador utilizado.

Quanto ao índice EPT (Ephemeroptera, Plecoptera e Trichoptera), somente foram encontrados 2 representantes destas ordens nas amostras coletadas no verão, um trichoptera na amostra 1 do ponto 1 e um Plecoptera na amostra 9 do ponto 2. Apesar de estes organismos estarem presentes nas amostras, estão 
presentes em baixa quantidade, portanto não se pode considerar o ambiente em equilíbrio, mas pode ser um indicativo de que o ambiente está em processo de recuperação e que organismos mais sensíveis estão iniciando um processo de recolonização do ambiente. Com a consolidação do processo de despoluição, removendo cargas pontuais e difusas, a tendência é que estes organismos mais sensíveis aumentem sua abundância e que haja a diminuição da dominância no corpo d'água.

Obteve-se com a aplicação da classificação segundo a DBO utilizada pelo programa "Córrego Limpo" que o corpo d’água ficou entre a classificação "Condições Boas" e "Condições Naturais". Já com a classificação segundo o Índice de Família de Hilsenhoff, os pontos analisados foram classificados como "Pobre". A diferença observada nas classificações da qualidade do corpo d'água através da utilização dos dois métodos corrobora a afirmação de que indicadores físicos e químicos apresentam resposta instantânea, enquanto os indicados biológicos tem resposta cumulativa. Portanto, fica clara a importância do uso conjunto de indicadores biológicos e indicadores físicos e químicos como ferramenta de avaliação da qualidade de corpos d'água.

Portanto, com o estudo foi possível observar as principais questões envolvidas no processo de recuperação de corpos d'água urbanos, passando desde aspectos sociais, como na questão da implantação do parque linear no córrego do Sapé; aspectos construtivos, como no caso da metodologia empregada nas canalizações; aspectos de hidrológicos, através de como o escoamento superficial participa no transporte de poluentes para o canal; e também aspectos físicos, químicos e biológicos, como no caso da determinação da qualidade da água do corpo d'água. A conclusão final deste trabalho é que o processo de despoluição de corpos d'água urbanos, devido ao seu forte caráter interdisciplinar, demanda, para seu perfeito funcionamento e manutenção, a integração e observância destes diversos fatores. 


\section{RECOMENDAÇÕES}

O estudo demonstrou a importância da utilização conjunta de indicadores físico, químicos e biológicos na caracterização da qualidade da água de corpos d'água, portanto é recomendado para futuros estudos, que abordem este tema, a utilização destes indicadores em conjunto, pois o uso isolado de somente um deles pode não refletir a real situação do corpo d'água.

Como vimos o país carece de estudos que tratem da caracterização, influência e medidas de controle da carga difusa produzida em bacias hidrográficas, sejam elas urbanas ou rurais, portanto é recomendado que estudos que abordem temas relativos à drenagem urbana, recuperação de corpos d'água e gestão dos recursos hídricos, abordem também de alguma forma a questão das cargas difusas, não só para contribuir para a evolução da ciência, mas também para maior popularização do assunto.

Este estudo, para não fugir de seu enfoque principal, abordou superficialmente a questão sobre os materiais e técnicas empregados no tratamento de canalizações e sua harmonização com questões relativas ao ecossistema aquático, portanto fica recomendado para futuros estudos o aprofundamento da questão, a fim de munir as projetistas e construtoras de informações relevantes para melhor escolha do tratamento dos seus canais projetados. 


\section{REFERÊNCIAS BIBLIOGRÁFICAS}

AGENDA 21 Brasileira: Metodologia e Roteiro de Trabalho. Comissão de Políticas de Desenvolvimento Sustentável e da Agenda 21 Nacional do Ministério do Meio Ambiente e da Amazônia Legal, 1998.

AKINAGA, Patrícia. H. ; MORINAGA,Carlos Minoru ; PELLEGRINO,Paulo Renato Mesquita . O caso da favela do Sapé e do projeto do parque linear 28: conflito ou solução?. In: Seminário Nacional sobre o Tratamento de áreas de preservação permanente em meio urbano e restrições, 2007, São Paulo. APP URBANA 2007, 2007.

ANA, Agência Nacional de Águas. Panorama da Qualidade das Águas Superficiais no Brasil: 2012. Brasília, DF: ANA, 2012 - Disponível em: <http:// arquivos.ana.gov.br/institucional/sge/CEDOC/Catalogo/2012/PanoramaAguasSuperfi ciaisPortugues.pdf >>. Acessado em 19/10/2012.

ANMMA, Associação Nacional de Órgãos Municipais de Meio Ambiente, 2011 Apresentação do Relatório Anual da Secretária do Verde do Município de São Paulo - Disponível em: <http://www.anamma.com.br/imagens_conteudo/userfilesfile/ 2011\%20-\%20SVMA\%20-\%20apresenta\%C3\%A7\%C3\%A30\%20\%5BModo\%20de \%20Compatibilidade\%5D.pdf>.Acessado em 11/05/2012.

ASLO, Association for the Sciences of Limnology and Oceanography - A Surber sampler being used to collect organisms in a shallow stream- Photo by Ray Drenner Disponível em: <http://www.aslo.org/photopost/showphoto.php/photo/112/title/surbersampler/cat/509> .Acessado em 10/05/2012.

ATLAS AMBIENTAL DO MUNICÍPIO DE SÃO PAULO (2002) - Disponível em: $<$ <ttp://atlasambiental.prefeitura.sp.gov.br>. Acessado em 24/02/2011.

BAIN, Robert; WRIGHT, Jim; YANG, Hong; PEDLEY, Steve; GUNDRY, Stephen e BARTRAM, Jamie - Improved but not necessarily safe: Water access and the Millennium Development Goals - Global Water Forum - Paper 1225 - 2012

BARBOSA, Heloiza Ramos; TORRES, Bayardo Baptista. Microbiologia Básica. São Paulo. Editora Atheneu - 1ª Edição - 1998 - Cap. 3 e 4. 
BARTALINI, Vladimir. Os córregos ocultos e a rede de espaços públicos urbanos. Pós-Revista do Programa de Pós Graduação em Arquitetura e Urbanismo da FAUUSP, São Paulo, n. 16, dez. 2004.

BEGON, Michael; HARPER, John L.; TOWNSEND, Colin R. - Ecologia - de Indivíduos a Ecossistemas. Editora Artmed, 4를ição, 2007.

BRAGA, Benedito et al. Introdução à engenharia ambiental. São Paulo: Pince Hall, 2002.

BRANCO, S. M. (1986). Hidrobiologia aplicada à engenharia sanitária, São Paulo, 3a Edição, CETESB/ASCETESB.

BRIGHETTI, G. et al. Revestimentos de Canais e Cursos D'água. Manual Técnico. FCTH, 1999.

BÖHRINGER, Friedrich - Foto: Ninfa de Plecoptera. Disponível em: <http:// www.zsmblog.de/tag/plecoptera/> Acessado em 06/05/2012.

CALLISTO, M. et al. Biodiversity assessment of benthic macroinvertebrates along a reservoir cascade in the lower São Francisco river (northeastern Brazil). Brazilian Journal of biology, v. 65, n. 2, p. 229-240, 2005.

CALOR, A.R. Trichoptera. In: Guia on-line de Identificação de larvas de Insetos Aquáticos do Estado de São Paulo, 2007. Disponível em: <http://sites.ffclrp.usp.br/ aguadoce/index_trico> Acessado em 06/05/2012.

CANHOLI, A. P. Drenagem urbana e controle de enchentes. Oficina de Textos, São Paulo, 2005.

CARMOUZE, J. P. - O Metabolismo dos ecossistemas aquáticos: fundamentos teóricos, métodos de estudo e análises químicas. Editora Edgard Blücher - 1994 FAPESP - São Paulo - Cap. 7.

CGE, Centro de Gerenciamento de Emergências - Pior estiagem da capital de São Paulo - Disponível em: <http://www.cgesp.org/v3/> Acessado em 10/04/2013. 
CETESB, Companhia de Tecnologia de Saneamento Ambiental. Variáveis de qualidade das águas. s/d. Disponível em: <http://www.cetesb.sp.gov.br/agua/aguassuperficiais/109-variaveis-de-qualidade-das-aguas >. Acesso em: 14/10/2012.

CECCHI, G.; MUNAFÒ, M.; BAIOCCO, F.; ANDREANI, P.; MANCINI, L. Estimating river pollution from diffuse sources in the Viterbo province using the potential nonpoint pollution index. Annali dell' Istituto Superiore di Sanità, Roma, v. 43, n. 3, p. 295 a $301-2007$.

CLICKCIÊNCIA - Edição 17, Matéria 5 : Insetos de Qualidade - 2009 - Foto de uma ninfa de Ephemeroptera. Disponível em: <http://www.clickciencia.ufscar.br/portal/ edicao17/materia5_detalhe.php> Acessado em 06/05/2012.

CONAMA 357 de 17 d e Março de 2005 - Conselho Nacional do Meio Ambiente, 2005.

CONFERÊNCIA DAS NAÇÕES UNIDAS SOBRE ASSENTAMENTOS HUMANOS HABITAT II, 2, 1996, Istambul. Relatório nacional brasileiro. Brasília, 1996.

CONSTITUIÇÃO FEDERAL DE 1988 - artigos 39 a 42 do Estatuto da Cidade lei no $10.257 / 2001$.

CÓRREGO LIMPO - Informações, mapas, planilhas e fotos obtidas junto à coordenação do programa "Córrego Limpo" durante a elaboração da pesquisa e outras informações disponíveis em: <http://www.corregolimpo.com.br> Acessado em 18/02/2011.

CORTES, R.; PINTO, P.; FERREIRA, M. T.; MOREIRA, I. - Qualidade biológica dos ecossistemas fluviais - Ecossistemas Aquáticos e Ribeirinhos. Instituto da Água, Ministério das Cidades, Ordenamento do Território e Ambiente, Lisboa, 2002.

COSTA, C.; IDE, S.; SIMONKA, C. E. Insetos imaturos: Metamorfose e identificação. Ribeirão Preto: Holos, 2006.

DAEE, Departamento de Águas e Energia Elétrica - Disponível em: < http://www.daee.sp.gov.br/index.php?option=com_content\&view=article\&id=370:parq 
ue-varzeas-do-tiete-o-maior-parque-linear-do-mundo\&catid=48:noticias\&ltemid=53> Acessado em 11/05/2012.

Declaração do Rio de Janeiro sobre o Meio Ambiente e Desenvolvimento (1992).

DNREC, Delaware Department of Natural Resources and Environmental Control Division of Watershed Stewardship: Drainage and Stormwater Section - Texto: Technical Resources for Stormwater Facility Maintenance - Disponível em: http://www.dnrec.delaware.gov/swc/drainage/pages/homeowners.aspx> Acessado em 31/10/2012.

DROBENKO, B. - Texto: As Cidades Sustentáveis - Disponível em < http:// pt.scribd.com/doc/52146709/Bernard-Drobenko-As-cidades-sustentaveis> Acessado em 19/05/2011.

EHLERS, M. (1991). Remote sensing and geographic information systems: image integrated information systems.In: Johnson, A. I.; Petterson, C. B., Fulton, J. L. Geographic Information Systems (GIS) and Mapping -Practices and Standards. ASTM STP 1126, eds. American Society for Testing and Materials, Philadelphia, 1991.

EIGER, S.; ARANHA, C. H.; GOMES, M. C. A.; PEREZ, L. S. N.; NETO, A. S. B. Modelagem matemática de cargas difusas na bacia do Guarapiranga, São Paulo Anuário do XIII Simpósio Brasileiro de Recursos Hídricos,1999.

EMPLASA, Empresa Metropolitana de Planejamento da Grande São Paulo S.A. Carta da região metropolitana de São Paulo - Cartas: HORTO FLORESTAL - 343481-AT (1991) / SANTANA - 3436-81-AT (1994).

ESTEVES, F. A. - Fundamentos de limnologia, Rio de Janeiro, - Editora Interciência Ltda. - 1998 - FINEP.

FERNÁNDEZ, H. R.; DOMÍNGUEZ, E. Guia para la Determinación de los Artrópodos Bentônicos Sudamericanos. Tucumán - Argentina: Universidad Nacional de Tucumán/Faculdad de Ciências Naturales e Instituto M. Lillo, 2001. 
FERREIRO, N. R. B. Caracterização da Qualidade Ecológica do Rio Tua. Faculdade de Ciências da Universidade do Porto - Departamento de Zoologia e Antropologia. Dissertação de Mestrado, 2007.

FLORENZANO, T. G. Imagens de Satélite para Estudos Ambientais. São Paulo: Oficina de Textos, 2002.

FRIEDRICH, Daniela - O parque linear como instrumento de planejamento e gestão das áreas de fundo de vale urbanas - Dissertação de Mestrado apresentada na Universidade Federal do Rio Grande do Sul. Faculdade de Arquitetura. Programa de Pós-Graduação em Planejamento Urbano e Regional em 2007 - Disponível em: < http://hdl.handle.net/10183/13175> Acessado em 10/05/2012.

GOMES, A. S. - Apostila: Análise de dados ecológicos - Universidade Federal Fluminense, UFF - Instituto de Biologia, Centro de Estudos Gerais, Departamento de Biologia Marinha, Niterói, 2004.

GUIMARÃES, Paulo Ricardo Bittencourt. Métodos Quantitativos Estatísticos Curitiba: IESDE Brasil S.A., 2008.

HELTSHE, J. F. \& N. E. FORRESTER. Estimating species richness using the jackknife estimate procedure - 1983 - Biometrics 39.

HORTON, R. E. Erosional development of streams and their drainage basins: Hydrographical approach to quantitative morphology. Geological Society of America Bulletin, v.56, n.2, p.275-370, 1945.

IBGE, Instituto Brasileiro de Geografia e Estatística - Séries estatísticas e Históricas - Disponível em: <http://seriesestatisticas.ibge.gov.br > Acessado em 14/10/2012.

IBGE, Instituto Brasileiro de Geografia e Estatística. Manual Técnico de Uso da Terra. 2ª Edição - Rio de Janeiro - 2007.

LARENTIS, D. G. Modelagem Matemática da Qualidade da Água em Grandes Bacias: Sistema Taquari - Antas- RS. Dissertação de Mestrado. UFGRS. Instituto de Pesquisas Hidráulicas - IPH, 2004. 
LECCI, L.S. \& FROEHLICH, C.G. 2007. Plecoptera. In: Guia on-line: Identificação de larvas de Insetos Aquáticos do Estado de São Paulo. Disponível em: <http://sites.ffclrp.usp.br/aguadoce/guiaonline>. Acessado em 06/05/2012.

LEI FEDERAL № 6.938 DE 31 DE AGOSTO DE 1981. Dispõe sobre a Política Nacional do Meio Ambiente, seus fins e mecanismos de formulação e aplicação, e dá outras providencias. Senado Federal. Brasília, DF. V. I, 1981.

LIMA, L.C.T.M. Simulação da Qualidade da Água em uma Bacia Hidrográfica: Aplicação a Bacia do rio Curu (CE). Dissertação (Mestrado em Engenharia Hidráulica). Universidade Federal do Rio Grande do Sul, Porto Alegre, 1998.

MACEDO, D. R.; CALLISTO, M.; MAGALHÃES, A.P. - Restauração de Cursos d'água em Áreas Urbanizadas: Perspectivas para a Realidade Brasileira - RBRH Revista Brasileira de Recursos Hídricos Volume 16 n.3 - Jul/Set 2011, 127-139.

Manual de procedimentos e técnicas laboratoriais, voltado para análise de águas e esgotos sanitários e industriais. Escola Politécnica da Universidade de São Paulo Departamento de Engenharia Hidráulica e Sanitária Laboratório de Saneamento "Profo Lucas Nogueira Garcez" - 2004.

MARIANO, R.. \& FROEHLICH, C.G. 2007. Ephemeroptera. In: Guia on-line: Identificação de larvas de Insetos Aquáticos do Estado de São Paulo. Froehlich, C.G. (org.). Disponível em: <http://sites.ffclrp.usp.br/aguadoce/guiaonline> Acessado em 06/05/2012.

MARZZOCO, A.; TORRES, B.B. Bioquímica básica. 3.ed. Rio de Janeiro: Guanabara Koogan, 2007. Cap. 1 e 2.

MAZZINI, F.. Efeitos da resolução taxonômica de invertebrados bentônicos no diagnóstico da qualidade de ecossistemas lóticos. Dissertação de mestrado, USP, São Paulo - 2007.

MDA - Minnesota Department of Agriculture. "Conservation Practices | Minnesota Conservation Funding Guide: Grass Filter Strip. Disponível em: <http://www. mda.state.mn.us/protecting/conservation/practices/buffergrass.aspx>. Acessado em: 31/10/2012. 
MENDES, B. \& OLIVEIRA, J.F.S.- Qualidade da água para consumo humano Lidel, Edições Técnicas, Lda, Lisboa - 2004.

MORENO, P.; FRANÇA, J.S.; FERREIRA, W.R.; PAZ, A.D.; MONTEIRO, I. \& CALLISTO, M. Use of the BEAST model for biomonitoring water quality in a Neotropical basin. Hydrobiologia - 2009 - 225 a 250p.

MORETTI, Marcelo da Silva. Atlas de identificação rápida dos principais grupos de macroinvertebrados bentônicos. Belo Horizonte, maio de 2004. Disponível em: <http://www.icb.ufmg.br/labs/benthos/index_arquivos/pdfs_pagina/Curso\%20Biomoni toramento/Arquivos/Atlas.pdf>. Acessado em 15/08/2012.

MUNAFÒ, $M$ et al., River pollution from noun-point sources : a new simplified method of assessment. Journal of Environmental Management, 2005 Volume 77 -90-99p.

NASCIMENTO, L. V. - Variáveis físicas e químicas da água, 2011, Adaptado de CPRM /SUREG/BH - Agência Técnica da Bacia do Rio Doce - Disponível em: < http://www. fcth.br/public/cursos/phd5028/Zoneamento\%20das\%20Aguas/tema12> Acessado em 18/05/2011.

NOVOTNY, Vladimir; SUNG, Hung-Ming; BANNERMAN, Roger; BAUM, Ken Estimating Nonpoint Pollution from Small Urban Watersheds - Source: Journal (Water Pollution Control Federation), Vol. 57, No. 4 (Apr., 1985), pp. 339-348 Disponível em: <http://www.jstor.org/stable/25042596> - Acessado em 06/05/2012.

NOVOTNY, Vladimir; OLEM, Harvey - Water quality: Prevention, identification and management of diffuse pollution - New York: Van Nostrand Reinhold, 1994.

NOVOTNY, Vladimir, Water quality: Diffuse pollution and watershed management 2ª Edição - New York: J. Wiley, 2003.

PNUD - 20ª edição do Relatório de Desenvolvimento Humano, 2010 - Disponível em:<http://hdr.undp.org/en/media/HDR_2010_PT_Complete_reprint.pdf> - Acessado em 06/05/2012. 
POCINHO, Margarida. Estatística II - Teoria e exercícios passo a passo, 2010 Disponível em:< http://docentes.ismt.pt/ m_pocinho/Sebenta_estatistica_II_com_ anexos_2010.pdf> - Acessado em 20/05/2013.

PORTO, Mônica F. Aspectos qualitativos do escoamento superficial em áreas urbanas. TUCCI, C. E. M; PORTO, Rubem La Laina; BARROS, Mário T. de Barros (Org.). Drenagem Urbana. In:. Porto Alegre: ABRH e Editora da UFRGS, 1995 - 387$414 p$.

PORTO, Mônica F. Sistema de gestão da qualidade das águas: Uma proposta para o caso brasileiro, 2002 - Escola politécnica-USP - 130-135p.

PRODANOFF, Jorge Henrique Alves - Avaliação da poluição difusa gerada por enxurradas em meio urbano - Tese de doutorado em Engenharia Civil, Universidade Federal do Rio de Janeiro, Rio de Janeiro, 2005.

REICHARDT, K. - A água nos sistemas agrícolas. São Paulo: Manole LTDA, 1987.

ROSENBERG, D.M. \& RESH, V.H. Introduction to freshwater biomonitoring and benthic macroinvertebrates. In: ROSENBERG, D.M., RESH, V.H., eds. Freshwater biomonitoring and benthic macroinvertebrates. New York, Chapman and Hall - 1993 - Cap. 1.

RUPPERT, E. E.; BARNES, R.D. Zoologia dos Invertebrados. 6 ed. São Paulo: Ed. Roca. 1996 - Cap. 16.

SABESP, 2010 - "Prestação de Serviços Técnicos Especializados para Capacitação dos Técnicos para Implementação das Estratégias de Governança Colaborativa" Diretoria Metropolitana da SABESP - São Paulo, maio de 2010.

SAISP, Sistema de Alerta a Inundações de São Paulo - Histórico de precipitação para Zona Oeste no período de janeiro de 2007 a março de 2012 - FCTH Fundação Centro Tecnológico de Hidráulica.

SANTOS, Rozely Ferreira dos - Planejamento ambiental: teoria e pratica , $1^{\circ}$ Edição - 2004 - Editora Oficina de textos. 
SILVEIRA, P. M., QUEIROZ, J. F., BOEIRA, R. C. - Protocolo de Coleta e Preparação de Amostras de Macroinvertebrados Bentônicos em Riachos, 2004 CNPMA - Embrapa Meio Ambiente - Disponível em: <http://www.cnpma.embrapa.br/ download/comunicado_19.pdf> Acessado em 10/05/2012.

SOLIA, Mariângela; FARIA, Odair Marcos; ARAÚJO, Ricardo. Mananciais da região metropolitana de São Paulo. São Paulo: Sabesp, 2007.

SOUZA, Vladimir Caramori Borges. GOLDENFUM, Joel Avruch. "Trincheiras de infiltração como controle de escoamento superficial: um estudo experimental", 2000.

SOUZA, Vladimir Caramori Borges. "Estudo experimental de trincheiras de infiltração no controle da geração do escoamento superficial”, 2002.

STEINKE, Valdir Adilson; SAITO, Carlos Hiroo. Exportação de carga poluidora para identificação de áreas úmidas sob risco ambiental na bacia hidrográfica da Lagoa Mirim. Soc. nat. (Online), Uberlândia , v. 20, n. 2, Dec. 2008 . Available from $<$ http://www.scielo.br/scielo.php?script=sci_arttext\&pid=S1982-45132008000200003 \&lng=en\&nrm=iso $>$. access on 29 Set. 2012.

STRAHLER, A. N. Hypsometric (area-altitude) - analysis of erosion al topography. Geological Society of America Bulletin, v.63, n.10, p.1117-1142, 1952.

STRIXINO, S. T. Larvas de Chironomidae - Guia de Identificação. Universidade Federal de São Carlos, Laboratório de Entomologia Aquática, 2011.

TOMAZ, Plínio. Livro: Poluição Difusa - Editora Navegar - São Paulo - 1ª Edição Publicação: 2006. Cap. 3.

TUCCI, Carlos E.M. - Águas Urbanas. Estudos Avançados, v22, n63 - 2008 Disponível em < http://www.scielo.br/scielo.php?script=sci_arttext\&pid=S0103$40142008000200007 \&$ Ing=en\&nrm=iso $>$. Acessado em 08/05/2012.

UFRGS, Universidade Federal do Rio Grande do Sul - Revitalização do Arroio Cheong Gye Cheon - Disponível em <http:// paginas.ufrgs.br/arroiodiluvio/a-baciahidrografica/imagens-de-seul>. Acessado em 11/05/2012. 
UFSM, Universidade Federal de Santa Maria - Grupo de Pesquisas em Modelagem HidroAmbiental e Ecotecnologias - Texto: TRINCHEIRAS DE INFILTRAÇÃO Disponível em: <http://w3.ufsm.br/ecotecnologias/index.php? option=com_content\&view=article\&id=77\&ltemid=76> Acessado em 31/10/2012.

USEPA, United States Environmental Protection Agency, Methodology for Analysis of Detention Basins for Control of Urban Runoff Quality - 1986.

USEPA, United States Environmental Protection Agency, National Management Measures to Control Nonpoint Source Pollution from Agriculture, EPA 841-B-03-004 $-2003$.

USEPA, United States Environmental Protection Agency - Foto: Larva de Trichoptera - Disponível em: <http://www.epa.gov/bioiweb1/html/photos_invertebra tes_caddisflies.html> Acessado em 06/05/2012.

USEPA, United States Environmental Protection Agency - Texto: Wet Ponds Disponível em:< http://cfpub.epa.gov/npdes/stormwater/menuofbmps/index.cfm? action=factsheet_results\&view=specific\&bmp=68> Acessado em 31/10/2012.

WALESH, S. G. - Livro: Urban Surface Water Management, New York, John Wiley \& Sons - Publicação: 1989. Cap. 1.

ZAR, J. H. - Biostatistical Analysis (3 rd Ed). New Jersy: Prentice Hall, 1996 - 662p. Published by: Water Environment Federation. 
8 ANEXOS 


\section{A utorização para atividades com finalidade científic a}

\begin{tabular}{|c|c|}
\hline Húmer o 31832-1 & Data da Emissão: 17/11/2011 08:39 \\
\hline \multicolumn{2}{|l|}{ Dados do titular } \\
\hline Nome: Juliana Caroline de Alencar da Sitra & CPF: $345.680 .658-28$ \\
\hline \multicolumn{2}{|c|}{$\begin{array}{l}\text { Título do Projeto: EFICIÉNCIA DO USO DE INDICADORES EIOLÓGICOS NA AVAUAÇÃO DA POLUIÇÃO DIFUSA EM CORPOS D?ÁGUA EM } \\
\text { BACIAS URBANAS. ESTUDO DE CASO: CÓRREGO DO SAPÉ? RIO PEQUENO? SÃO PAULO-SP. }\end{array}$} \\
\hline Nome da Instituição: ESC OLA POLITÉCNICA DA UNNERSIDADE DE SAO PAULO & CNPJ: 63025.5301002409 \\
\hline
\end{tabular}

Cronograma de atividades

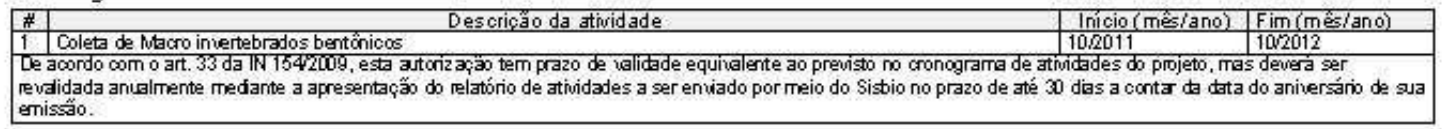

Observaçổes e ressalvas

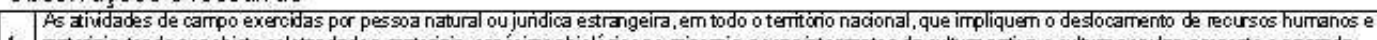

1 materiais, tendo por objeo coletar dados, materias, espécimes biológicose minerais, peças integrantes da cultura native e cultura popular, preserte e passada,

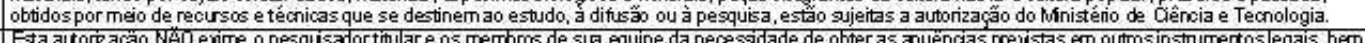

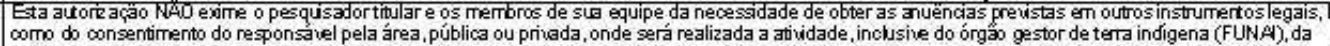

2 unicte de conservaçâo estadual, distrital ou municipal, au do proprietánio, amendatánio, posseiro ou morador de área dentro dos lirrites de unidade de conseneçâo Ederal cujo processo de regularizaçâa fundiária encontra se emcurso.

Ete documerto somente podera ser utiz a0 para os especifica esta Atoniz ą̧̃o, nâo podendo ser uilizado pas finscomenias, ndustriais ou esportivos. 0 material biológico coletado deverá ser utiliz ado para atividades cientícas ou didáticas no âmbito do ensino superio

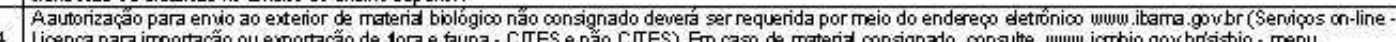

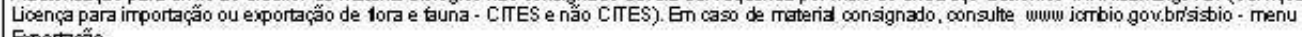
Exportaç̃o.

ao grupo taxonônrico de interesse, evitando a morte ou dano signiicativo a outros gupos; e empregar estorco de coleta ou captura que não comprometa a viatilidade de popuacôes do grupo taxonâmico de interesse en condiçâo in situ.

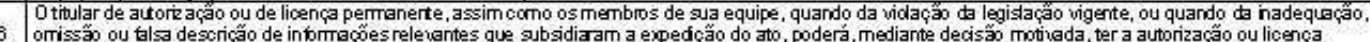

suspensa au revogada pelo lCMEio e o material biológico coletado apreendido nos termos da lejslação brasieira em vigor.

7 pro platar

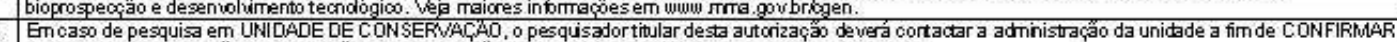

8 Encaso de pesquisa em UNIDADE dín CONSER

Locais onde as atividades de campo serẫo executadas

\begin{tabular}{|c|c|c|c|c|}
\hline$\frac{\pi}{1}$ & Municipio & UF & Descricăo do local & Tipo \\
\hline & SAUU PAUU & $3 \mathrm{H}$ & & Fora de UC \\
\hline 2 & TRBMBMBE & SP & MANTIQUEIRA & UC Federal \\
\hline
\end{tabular}

Atividades $X$ Táxons

\begin{tabular}{|c|c|c|}
\hline \# & Athuidade & Taxore \\
\hline 1 & Coletamansporte de amostras bidógicas in situ & hisects \\
\hline 2 & 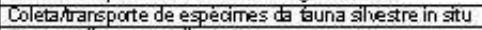 & hsecta ("Otde:500) \\
\hline & Obsenaçäo e gravaçäo de imagem ou som & hisecta \\
\hline
\end{tabular}

× Otde, de indvíduos por espéciedocalidadeluridade de consenação, a serem coleados durate um ano.

Este documento (Autorzação para atividades com finalidade científica) foi expe dido com base na Instrução Normativa no1542007. At avés do código de autenticação abaixo, qualquer cidadåo poderá verificar a autenticidade ou regularidade deste documento, por meio da página do SisbiólcmBio na Internet (umum iombio gov.brisis bio)

Código de autenticação: 21287192 
Ministério do Meio Ambiente - MMA

Instituto Chico Mendes de Conservação da Biodiversidade - ICMBio

Sistema de Autor zação e Informaçẫo em Biodiversidade - SISBIO

\section{Autorização para atividades com finalidade cientific a}

\begin{tabular}{|c|c|}
\hline Húmer o 31832-1 & Data da Emissão: 17/11/2011 08:39 \\
\hline \multicolumn{2}{|l|}{ Dados do titular } \\
\hline Nome: Juliana Caroline de Alencar da Situa & CPF: $345.680 .658-28$ \\
\hline \multicolumn{2}{|c|}{$\begin{array}{l}\text { Titulo do Projeto: EFICIÉNCIA DO USO DE INDICADORES BIOLÓGICOS NA AVAUAÇÃO DA POLUIÇÃO DIFUSA EM CORPOS D?ÁGUA EM } \\
\text { BACIAS URBANAS. ESTUDO DE CASO: CÓRREGO DO SAPÉ? RIO PEQUENO? SÁO PAULO-SP. }\end{array}$} \\
\hline Nome da Instituição : ESC OLA POLITÉCNICA DA UN NERSIDADE DE SAO PAULO & CNPJ: 63025.530002409 \\
\hline
\end{tabular}

Material e métodos

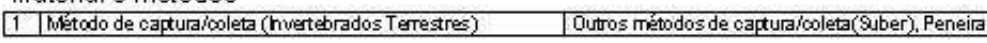

Destino do material biológico coletado

\begin{tabular}{|l|l|l|}
\hline \# & Nome local destino & Tipo Destino \\
\hline
\end{tabular}

Este documento (Autorização para athưidades com fin alidade científica) foi expe dido com base na Instrução Normativa no1542007. Att avés do código de autenticação abaixo, qualquer cidadão poderá verificar a autenticidade ou regularidade deste documento, por meio da página do SisbiólcmBio na Internet (wumus.ionbio.gov.brisis bio)

Código de autenticação: 21287192 


\section{A utorização para atividades com finalidade científic a}

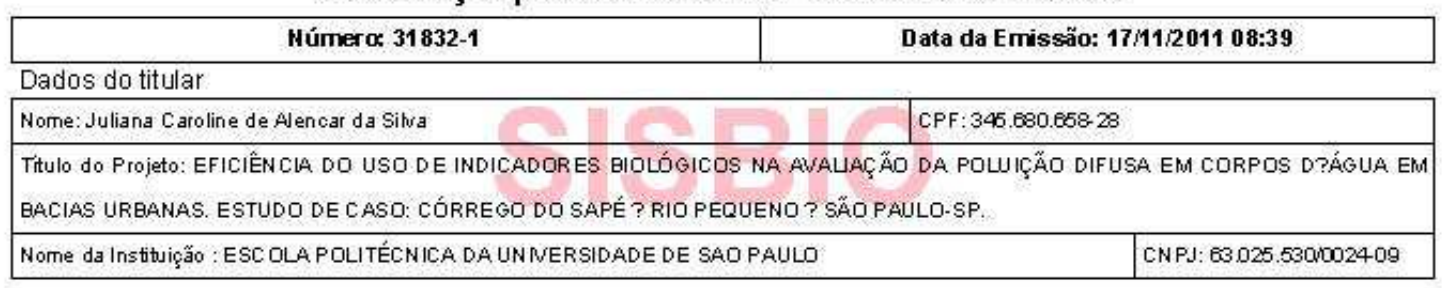

\section{Registro de coleta imprevista de material biológico}

De acordo com a Instruçẫo Normativa n¹54/2007, a coleta imprevista de material biológico ou de substrato nẫo contemplado na autorizaçẫo ou na licença permanente deverá ser anotada na mesma, em campo específico, por oc asiấo da coleta, devendo esta coleta imprevista ser comunicada por meio do relatório de atividades. $Q$ transporte do material biológico ou do substrato deverá ser acompanhado da autorizaçẫo ou da licença permanente com a devida anotaçẫo. $O$ material biológico coletado de forma imprevista, deverá ser destinado à instituiçẫo científica $\mathrm{e}$, depositado, preferencialmente, em coleçấo biológica científica registrada no Cadastro Nacional de Coleçốes Biológic as (CCBIO).

\begin{tabular}{|c|c|c|c|c|}
\hline Tír<on & Otde. & Tipo de amostra & $\begin{array}{l}\text { Otde. } \\
\end{array}$ & Dat \\
\hline & & & & \\
\hline & & & & \\
\hline & & & & \\
\hline & & & & \\
\hline & & & & \\
\hline & & & & \\
\hline & & & & \\
\hline & & & & \\
\hline & & & & \\
\hline & & & & \\
\hline & & & & \\
\hline
\end{tabular}

*Identificar o espécime no nivel taxonômico possível.

Este documento (Autorização para atividades com fin alidade científica) foi expedido com base na Instrução Normativa no1542007. At avés do código de autenticação abaixo, qualquer cidadão poderá verificar a autenticidade ou regularidade deste documento, por meio da página do SisbiólcMBio na Internet (umum iombio gov.brisis bio).

Código de autenticação: 21287192 


\section{A utorização para atividades com finalidade científic a}

\begin{tabular}{|c|c|c|}
\hline Número: 36501-1 & Data da Emissão: 21/09/2012 12:29 & Data para Revalida ção*: 21/10/2013 \\
\hline
\end{tabular}

Dados do titular

\begin{tabular}{|c|c|}
\hline Nome: Juliana Caroline de Alencar da Situa & CPF: 346.680 .668 .28 \\
\hline $\begin{array}{l}\text { Titulo do Projeto: RECUPERAÇÃO DE CÓRREGOS URBANOS ATRAVÉS DO CO } \\
\text { CASO:PROGRAMA TCORREGO UMPO? }\end{array}$ & DE CARGAS PONTUAIS E DIFUSAS. ESTUL \\
\hline Nome da Instituição: ESC OLA POLITÉCNICA DA UN NERSIDADE DE SAO PAULO & CNPJ: 63.025 .5301002409 \\
\hline
\end{tabular}

Cronograma de atividades

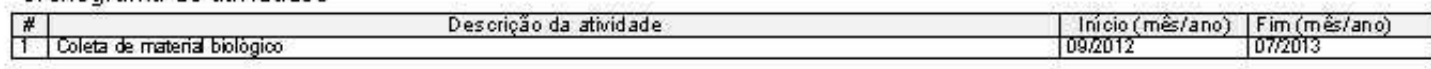

Observaçổes e ressalvas

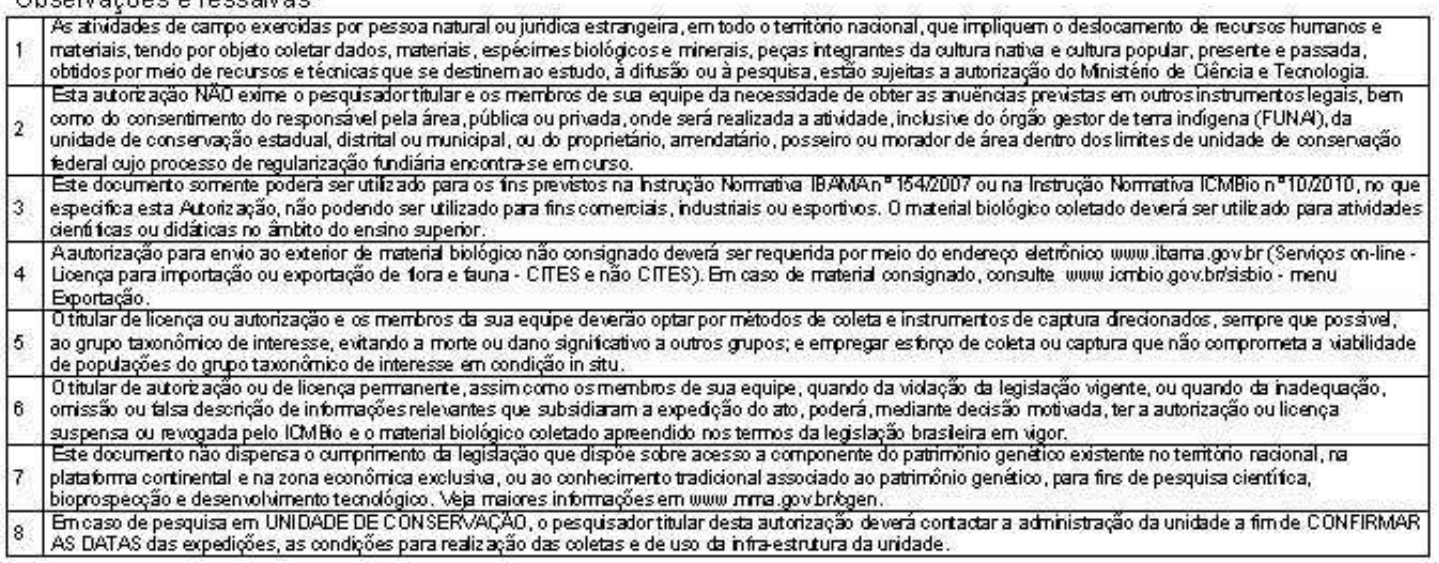

Locais onde as atividades de campo serẫo executadas

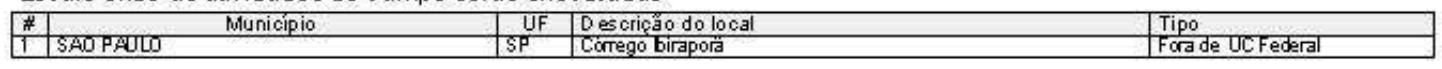

Atividades X Táxons

\begin{tabular}{|c|c|c|}
\hline \# & Afwidade & Taxons \\
\hline 1 & Captura de anirrais giluestres in situ & Ephemeroptera, Plecoptera, Trichoptera \\
\hline 2 & Coletamanspote de especintes do tana ghestre in situ & Étremeroptera ("Otde:50), Trichoptera ("ade: 50 ), Plecoptera ("Otde: 50 ) \\
\hline
\end{tabular}

"Otde. de indúduos por espécielocalidadeluridade de consen ação, a serem coleados durate um ano.

Material e métodos

Este documento (Autorização para atividades com fin alidade científica) foi expedido com base na Instrução Normativa nọ1542007. At avés do có digo de autenticação abaixo, qualquer cidadão poderá verificar a autenticidade ou regularidade deste documento, por meio da página do SisbiólcMBio na Internet (umum iambio gov.brisis bio).

Código de autenticação: 95847499 
Ministério do Meio Ambiente - MMA

Instituto Chico Mendes de Conservação da Biodiversidade -ICMBio

Sistema de Autorização e Informação em Biodiversidade - SISBIO

\section{Autorização para atividades com finalidade científic a}

\begin{tabular}{|c|c|c|}
\hline Número: $36501-1$ & Data da Emissão: 21/09/2012 12:29 & Data para Revalida ção*: $21 / 10 / 2013$ \\
\hline
\end{tabular}

Dados do titular

\begin{tabular}{|l|l|}
\hline Nome: Juliana Caroline de Alencar da Situa & CPF:346.680.658- 28
\end{tabular}

Título do Projeto: RECUPERAÇÃo DE CóRREgOS URBANOS ATRAVÉS DO CON TROLE DE CARGAS PONTUAIS E DIFUSAS: ESTUDO DE CASO:PROGRAMA TCÓRREGO UMPO?

Nome da Instituição : ESC OLA POLITÉCNICA DA UNNERSIDADE DE SAO PAULO CNPJ: 63025.530002409

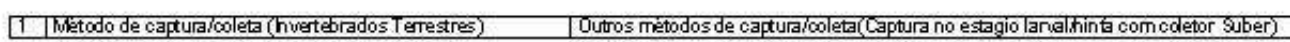

Destino do material biológico coletado

Nome local destino

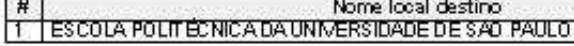
TipoDestino

Este documento (Autorzação para atividades com finalidade científica) foi expe dido com base na Instrução Normativa no1542007. At avés do código de autenticação abaixo, qualquer cidadão poderá verificar a autenticidade ou regularidade deste documento, por meio da página do SisbiólcMBio na Internet (num iombio gov.brisis bio).

Código de autenticação: 95847499 


\section{A utorização para atividades com finalidade científic a}

\begin{tabular}{|c|c|c|}
\hline Número: 36501-1 & Data da Emissão: 21/09/2012 12:29 & Data para Revalida ção*: 21/10/2013 \\
\hline
\end{tabular}

Dados do titular

\begin{tabular}{|l|l|}
\hline Nome: Juliana Caroline de Alencar da Situa & CPF:346.680.658- 28
\end{tabular}

Título do Projeto: RECUPERAÇÃo DE CóRREgOS URBANOS ATRAVÉS DO CON TROLE DE CARGAS PONTUAIS E DIFUSAS: ESTUDO DE CASO:PROGRAMA TCÓRREGO UMPO?

Nome da Instituição : ESC OLA POLITÉCNICA DA UNNERSIDADE DE SAO PAULO CNPJ: 63025.5301002409

\section{Registro de coleta imprevista de material biológico}

De acordo com a Instruçấo Normativa n`154/2007, a coleta imprevista de material biológico ou de substrato nẫo contemplado na autorizaçẫo ou na licença permanente deverá ser anotada na mesma, em campo específico, por oc asiấo da coleta, devendo esta coleta imprevista ser comunicada por meio do relatório de atividades. $Q$ transporte do material biológico ou do substrato deverá ser acompanhado da autorizaçẫo ou da licença permanente com a devida anotaçẫo. O material biológico coletado de forma imprevista, deverá ser destinado à instituição científica e, depositado, preferencialmente, em coleção biológica científica registrada no Cadastro Nacional de Coleçốes Biológic as (CCBIO).

\begin{tabular}{|c|c|c|c|c|}
\hline T́x́orts & atde. & Tipo de amostra & Qitde. & Date \\
\hline & & & & \\
\hline & & & & \\
\hline & & & & \\
\hline & & & & \\
\hline & & & & \\
\hline & & & & \\
\hline & & & & \\
\hline & & & & \\
\hline & & & & \\
\hline & & & & \\
\hline & & & & \\
\hline
\end{tabular}

Este documento (Autorização para athưidades com fin alidade científica) foi expedido com base na Instrução Normativa no 1542007. At aúés do código de autenticação abaঝo, qualquer cidadão poderá verificar a autenticidade ou regularidade deste documento, por meio da página do Sisbiólcmeio na Internet (numu iombio.gov.brisisbio).

Código de autenticação: 95847499 
Ministério do Meio Ambiente - MMA

Instituto Chico Mendes de Conservação da Biodiversidade - ICMBio

Sistema de Autor żação e Informaçẫo em Biodiversidade - SISBIo

\section{A utorização para atividades com finalidade científic a}

Número: 36501-1

Data da Emissão: 21/09/2012 12:29

Data para Revalidação*: 21/10/2013

${ }^{\pi}$ De acordo com o art. $33 \mathrm{da}$ IN 154/2009, esta autorização tem pr azo de validade equivalente ao previsto no cronograma de atividades do projeto

mas deverá ser revalidada anualmente mediante a apresentação do relatório de athvidades a ser enviado por meio do Sisbio no prazo de até 30 dias

a contar da data do aniversário de sua emissâo.

Dados do titular

Nome: Juliana Caroline de Alencar da Sibua

CPF: 346.680 .65828

Título do Projeto: RECUPERAÇÃO DE CÓRREGOS URBANOS ATRAVÉS DO CON TROLE DE CARGAS PONTUAIS E DIFUSAS: ESTUDO DE CASO:PROGRAMA TCÓRREGO UMPO?

Nome da Instituição : ESC OLA POLITÉCNICA DA UNNERSIDADE DE SAO PAULO CNPJ: 63025.530002409

*Identificar o espécime no nível taxonômico posśruel.

Este documento (Autorização para atividades com fin alidade científica) foi expedido com base na Instrução Normativa no1542007. At avés do código de autenticação abaixo, qualquer cidadão poderá verificar a autenticidade ou regularidade deste documento, por meio da página do Sisbiólcmeio na Internet (umum ianbio gov.brisis bio).

Código de autenticação: $\mathbf{9 5 8 4 7 4 9 9}$ 


\section{Operattor}

Cotia - SP, Rua Itafarma, 88

Jardim do Rio Cotia - CEP 06715-795

Tel.: (11) 5097.2249 - Fax: (11) 5097.2240

e-mail: comercialsp@operatorlab.com.br

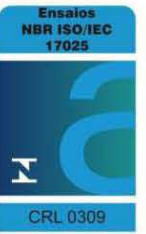

\begin{tabular}{|c|}
\hline $\begin{array}{l}\text { BOLETIM DE ANÁLISE N. } .^{\circ} 14655 / 2012-1.0 \\
\text { Processo Comercial N. }{ }^{\circ} 1709 / 2012-1\end{array}$ \\
\hline DADOS DO CONTRATANTE \\
\hline Contratante: Escola Politécnica - Usp \\
\hline CNPJ/CPF: 08.495.832/0001-38 \\
\hline Endereço: Avenida Prof. Luciano Gualberto, 158 Trav 3 - - São Paulo - SP CEP: 05.508-010 \\
\hline
\end{tabular}

DADOS DO SOLICITANTE

Solicitante: Escola Politécnica - Usp

CNPJ/CPF: 08.495.832/0001-38

Endereço de coleta: Avenida Prof. Luciano Gualberto, 158 Trav 3 - - São Paulo - SP CEP: 05.508-010

Legislação ou norma: Sem Comparativo

DADOS OBTIDOS EM CAMPO

Identificação do Ponto da Coleta: Ponto 02 - Em Frente № 272

Identificação do tipo de amostra: Efluente

Responsável pela Coleta: Operator/Eduardo Pedroso

\begin{tabular}{l|l} 
Data da coleta: 11/09/2012 & Horário da coleta: 16:50 hs
\end{tabular}

Data de entrada da amostra: 11/09/2012

Temperatura Ambiente $\left({ }^{\circ} \mathrm{C}\right)$

Presença de chuva nas últimas $24 \mathrm{hs}$ ?

$\mathrm{pH}-1$

$\mathrm{pH}-2$

$\mathrm{pH}-3$

eH Redox (mV) 1

eH Redox (mV) 2

eH Redox (mV) 3

Temperatura da Amostra $\left({ }^{\circ} \mathrm{C}\right) 1$

Temperatura da Amostra $\left({ }^{\circ} \mathrm{C}\right) 2$

Temperatura da Amostra $\left({ }^{\circ} \mathrm{C}\right) 3$

Oxigênio Dissolvido (mgO2/L) 1

Oxigênio Dissolvido (mgO2/L) 2

Oxigênio Dissolvido (mgO2/L) 3

Aspecto da Amostra

Cor (visual)

Odor

\begin{tabular}{|l|}
\hline 24 \\
\hline Sim \\
\hline 7,57 \\
\hline 7,57 \\
\hline 7,57 \\
\hline$-39,0$ \\
\hline$-39,0$ \\
\hline$-39,0$ \\
\hline 22,7 \\
\hline 22,7 \\
\hline 22,7 \\
\hline 2,45 \\
\hline 2,18 \\
\hline 2,32 \\
\hline Levemente Turva \\
\hline Amarelo Claro \\
\hline Inodoro \\
\hline
\end{tabular}

Data de emissão do relatório: 04/10/2012 
Cotia - SP, Rua Itafarma, 88 Jardim do Rio Cotia - CEP 06715-795 Tel.: (11) 5097.2249 - Fax: (11) 5097.2240 e-mail: comercialsp@operatorlab.com.br

RESULTADOS ANALITICOS

PARÂMETROS ACREDITADOS ISO/IEC ABNT NBR ISO/IEC 17025:2005

\begin{tabular}{|c|c|c|c|c|c|c|}
\hline \multicolumn{7}{|l|}{ Parâmetro } \\
\hline Parâmetros & Unidade & LQ & Resultados & $\begin{array}{c}\text { Incerteza } \\
( \pm)\end{array}$ & $\begin{array}{c}\text { Data do } \\
\text { Realização }\end{array}$ & M \\
\hline DBO & $\mathrm{mg} / \mathrm{L}$ & 2 & 5 & 1 & $12 / 09 / 2012$ & 61 \\
\hline Oxigênio Dissolvido & $\mathrm{mg} / \mathrm{L}$ & 0,50 & 2,32 & 000 & $12 / 09 / 2012$ & 110 \\
\hline Turbidez & NTU & 0,03 & 1,07 & 0,06 & $14 / 09 / 2012$ & 60 \\
\hline $\mathrm{pH}$ & --- & 0,10 & 7,57 & 0,03 & $12 / 09 / 2012$ & 30 \\
\hline Sólidos Dissolvidos Totais & $\mathrm{mg} / \mathrm{L}$ & 5 & 218 & 1 & $27 / 09 / 2012$ & 64 \\
\hline Nitrato & $\mathrm{mg} / \mathrm{L}$ & 0,07 & 0,78 & 0,009 & $12 / 09 / 2012$ & 35 \\
\hline Nitrogênio Amoniacal & $\mathrm{mg} / \mathrm{L}$ & 0,08 & 7,29 & 0,01 & $01 / 10 / 2012$ & 50 \\
\hline Alcalinidade Total & $\mathrm{mg} / \mathrm{L}$ & 5 & 87 & 5 & $27 / 09 / 2012$ & 32 \\
\hline Temperatura & ${ }^{\circ} \mathrm{C}$ & 1,0 & 22,7 & 0,15 & $12 / 09 / 2012$ & 58 \\
\hline Fosforo Total & $\mathrm{mg} / \mathrm{L}$ & 0,0200 & 0,324 & 0,0023 & 18/09/2012 & 75 \\
\hline DQO & $\mathrm{mg} / \mathrm{L}$ & 5 & 22 & 1 & $13 / 09 / 2012$ & 62 \\
\hline Alumínio Dissolvid & $\mathrm{mg} / \mathrm{L}$ & 0,005 & 0,194 & 0,0005 & $19 / 09 / 2012$ & 47 \\
\hline Cobre Dissolvido & $\mathrm{mg} / \mathrm{L}$ & 0,0017 & 0,003 & 0,00005 & $19 / 09 / 2012$ & 47 \\
\hline Ferro Dissolvido & $\mathrm{mg} / \mathrm{L}$ & 0,002 & 0,704 & 0,0005 & $19 / 09 / 2012$ & 47 \\
\hline Mercúrio Total & $\mathrm{mg} / \mathrm{L}$ & 0,00010 & $<0,00010$ & 0,00003 & $18 / 09 / 2012$ & 75 \\
\hline Antimônio & $\mathrm{mg} / \mathrm{L}$ & 0,0020 & $<0,0020$ & 0,0005 & $18 / 09 / 2012$ & 75 \\
\hline Arsênio Total & $\mathrm{mg} / \mathrm{L}$ & 0,0020 & $<0,0020$ & 0,0005 & $18 / 09 / 2012$ & 75 \\
\hline Bário Total & $\mathrm{mg} / \mathrm{L}$ & 0,0017 & 0,087 & 0,0001 & $18 / 09 / 2012$ & 75 \\
\hline Berílio Total & $\mathrm{mg} / \mathrm{L}$ & 0,0060 & $<0,0060$ & 0,0003 & $18 / 09 / 2012$ & 75 \\
\hline Boro Total & $\mathrm{mg} / \mathrm{L}$ & 0,0520 & $<0,0520$ & 0,0053 & $18 / 09 / 2012$ & 75 \\
\hline Cádmio Total & $\mathrm{mg} / \mathrm{L}$ & 0,0017 & $<0,0017$ & 0,0001 & $18 / 09 / 2012$ & 75 \\
\hline Chumbo Total & $\mathrm{mg} / \mathrm{L}$ & 0,0020 & $<0,0020$ & 0,0005 & $18 / 09 / 2012$ & 75 \\
\hline Cobalto Total & $\mathrm{mg} / \mathrm{L}$ & 0,0020 & $<0,0020$ & 0,0005 & $18 / 09 / 2012$ & 75 \\
\hline Cromo Total & $\mathrm{mg} / \mathrm{L}$ & 0,0060 & $<0,0060$ & 0,0015 & $18 / 09 / 2012$ & 75 \\
\hline Lítio Total & $\mathrm{mg} / \mathrm{L}$ & 0,0270 & $<0,0270$ & 0,0125 & $18 / 09 / 2012$ & 75 \\
\hline Manganês Total & $\mathrm{mg} / \mathrm{L}$ & 0,0030 & 0,303 & 0,0005 & $18 / 09 / 2012$ & 75 \\
\hline Níquel Total & $\mathrm{mg} / \mathrm{L}$ & 0,0017 & 0,003 & 0,0001 & $18 / 09 / 2012$ & 75 \\
\hline Prata Total & $\mathrm{mg} / \mathrm{L}$ & 0,0001 & 0,004 & 0,0000 & $18 / 09 / 2012$ & 75 \\
\hline Selênio Total & $\mathrm{mg} / \mathrm{L}$ & 0,0030 & 0,004 & 0,0005 & $18 / 09 / 2012$ & 75 \\
\hline Vanádio Total & $\mathrm{mg} / \mathrm{L}$ & 0,0040 & $<0,0040$ & 0,0010 & $18 / 09 / 2012$ & 75 \\
\hline Zinco Total & $\mathrm{mg} / \mathrm{L}$ & 0,0011 & 0,058 & 0,0003 & $18 / 09 / 2012$ & 75 \\
\hline 2-Clorofenol & $\mu g / L$ & 0,010 & $<0,010$ & 0.001 & $13 / 09 / 2012$ & 12 \\
\hline 1,2-Dicloroetano & $\mu g / L$ & 2,00 & $<2,00$ & 0,20 & $13 / 09 / 2012$ & 128 \\
\hline
\end{tabular}


Cotia - SP, Rua Itafarma, 88

Jardim do Rio Cotia - CEP 06715-795

Tel.: (11) 5097.2249 - Fax: (11) 5097.2240

e-mail: comercialsp@operatorlab.com.br

Parâmetro
\begin{tabular}{|l|c|c|c|c|c|c|}
\hline Parâmetros & Unidade & LQ & Resultados & $\begin{array}{c}\text { Incerteza } \\
(\mathbf{\pm})\end{array}$ & $\begin{array}{c}\text { Data de } \\
\text { Realização }\end{array}$ & M \\
\hline 1,1-Dicloroeteno & $\mu \mathrm{g} / \mathrm{L}$ & 2,00 & $<\mathbf{2 , 0 0}$ & 0,20 & $13 / 09 / 2012$ & 128 \\
\hline Estireno & $\mu \mathrm{g} / \mathrm{L}$ & 2,00 & $<\mathbf{2 , 0 0}$ & 0,20 & $13 / 09 / 2012$ & 128 \\
\hline Tetracloreto de Carbono & $\mu \mathrm{g} / \mathrm{L}$ & 1,00 & $<\mathbf{1 , 0 0}$ & 0,10 & $13 / 09 / 2012$ & 128 \\
\hline Tetracloroeteno & $\mu \mathrm{g} / \mathrm{L}$ & 2,00 & $<\mathbf{2 , 0 0}$ & 0,20 & $13 / 09 / 2012$ & 128 \\
\hline Triclorobenzenos & $\mu \mathrm{g} / \mathrm{L}$ & 0,07 & $<\mathbf{0 , 0 7}$ & 0,03 & $13 / 09 / 2012$ & 128 \\
\hline Tricloroeteno & $\mu \mathrm{g} / \mathrm{L}$ & 0,10 & $<\mathbf{0 , 1 0}$ & 0,03 & $13 / 09 / 2012$ & 128 \\
\hline Benzeno & $\mu \mathrm{g} / \mathrm{L}$ & 2,00 & $<\mathbf{2 , 0 0}$ & 0,13 & $13 / 09 / 2012$ & 128 \\
\hline Etilbenzeno & $\mu \mathrm{g} / \mathrm{L}$ & 2,00 & $<\mathbf{2 , 0 0}$ & 0,16 & $13 / 09 / 2012$ & 128 \\
\hline Tolueno & $\mu \mathrm{g} / \mathrm{L}$ & 2,00 & $<\mathbf{2 , 0 0}$ & 0,16 & $13 / 09 / 2012$ & 128 \\
\hline Xilenos & $\mu \mathrm{g} / \mathrm{L}$ & 2,00 & $<\mathbf{2 , 0 0}$ & 0,20 & $13 / 09 / 2012$ & 128 \\
\hline Oleos e Graxas & $\mathrm{mg} / \mathrm{L}$ & 5 & $<5$ & 0,2 & $17 / 09 / 2012$ & 46 \\
\hline
\end{tabular}

\section{RECUPERAÇÃO DOS SURROGATES}

14655/2012 - Efluente - Ponto 02 - Em Frente No 272

\begin{tabular}{|l|c|c|c|}
\hline Parâmetros & Unidade & LQ & Resultado \\
\hline Itrio & $\%$ & 0 & $\mathbf{8 7}$ \\
\hline p-Bromofluorbenzeno & $\%$ & 0,05 & $\mathbf{1 0 4 , 4 1}$ \\
\hline Tolueno-d8 & $\%$ & 0,05 & $\mathbf{8 9 , 8 3}$ \\
\hline 2-Fluorobifenil & $\%$ & 0,05 & $\mathbf{1 0 2 , 5 6}$ \\
\hline p-Terfenil d14 & $\%$ & 0,05 & $\mathbf{8 9 , 9 9}$ \\
\hline
\end{tabular}

L.D - Limite de Detecção

L.Q - Limite de Quantificação

(<) Abaixo do Limite de Detecção

\section{Notas:}

(1) Os resultados referem-se somente a amostra analisada.

(2) Plano de Amostragem / identificaçăo dos pontos a serem amostrados é de responsabilidade do cliente.

(3) Todas as análises foram realizadas dentro dos prazos de validade da amostra, conforme indicado nas normas: SMEMW 21 st Ed; EPA; NBR; ASTM; CETESB; INEA e normas técnicas vigentes e descritas nas instruções operacionais padrão de Coleta e Preservação de Amostras da OPERATOR.

(4) Os dados brutos obtidos na execução das análises estão à disposição, podendo ser solicitado a qualquer momento.

(5) A interpretação dos resultados leva em consideração a incerteza de medição do ensaio.

(6) As incertezas apresentadas nos boletins de análise são referente à incerteza expandida dos métodos analiticos.

Métodos de Referência

USEPA SW 846 - Method 8270 D - Semivolatile Organic Compounds by CG/MS rev 04 - Fev 2007

pH: SMEWW 4500 - H+ - B - Eletrometric Method

Alcalinidade: SMEWW 21th Ed. 2320 - Alkalinity

35 Ânions: USEPA SW 846 - Method 300.1 - Determination of Inorganic Anions in Drinking Water by lon Chromatography 


\section{7

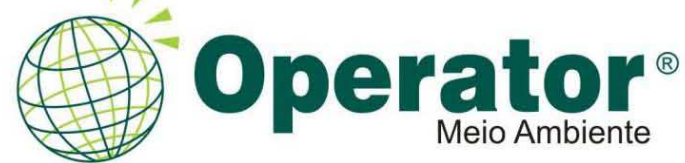

Cotia - SP, Rua Itafarma, 88

Jardim do Rio Cotia - CEP 06715-795

Tel.: (11) 5097.2249 - Fax: (11) 5097.2240

e-mail: comercialsp@operatorlab.com.br

\footnotetext{
Óleos e Graxas: SMEWW 5520 - Oil and Grease

47 Metais: SMEWW 3120 B Inductively Coupled Plasma (ICP) Method

50 Nitrogênio Amoniacal: SMEWW 4500 - NH3 - D - Ammonia-Selective Electrode Method

58 Temperatura: Leitura direta com Termohigrômetro

60 Turbidez: SMEWW 21th Ed. 2130 B - Nephelometric Method

61 DBO: SMEWW 21th Ed. 5210 B. Biochemical Oxygen Demand (BOD)

62 DQO: SMEWW 21th Ed. 5220 - D - Closed Reflux, Colorimetric Method

64 Sólidos Dissolvidos: SWEMM 2540 - C - Total Dissolved Solids Dried at $180^{\circ} \mathrm{C}$

75 USEPA SW 846 - Method 6010 C - In ductivily Coupled Plasma Atomic Emission Espectrometry

110 Oxigênio Dissolvido: SMEWW 4500 - 0 - Oxygen (Dissolved) 128 USEPA SW 846 - Method $8021 \mathrm{~B}$ - Aromatic and halogenated volatiles by gas chromatography using photo ionization and/or
}

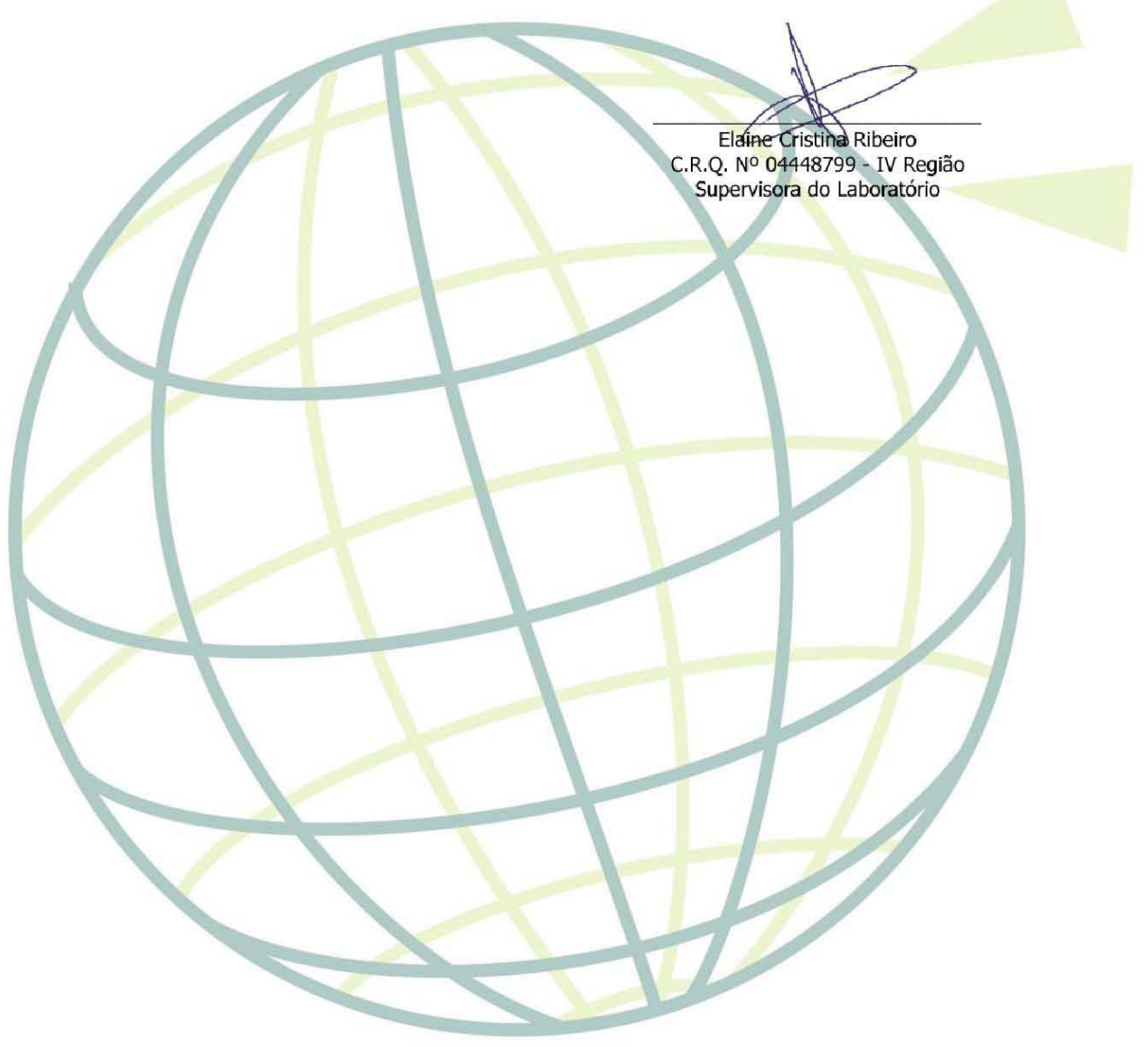

Página 4 de 4 /B.A. 14655/2012 - 1.0 Ponto 02 - Em Frente № 272 


\section{Operator}

Cotia - SP Rua Itafarma, 88

Jardim do Rio Cotia - CEP 06715-795

Tel.: (11) 5097.2249 - Fax: (11) 5097.2240

e-mail: comercialsp@operatorlab.com.br

Volta Redonda - RJ, Av. Sete de

Setembro, 449 - Aterrado - CEP 27213-310

Tel.: (24) 3337.4220 - Fax: (24) 3337.9832

e-mail: comercialvr@operatorlab.com.br

\begin{tabular}{|c|}
\hline $\begin{array}{l}\text { BOLETIM DE ANÁLISE N. } .^{\circ} 14655 / 2012-1.0 \\
\text { Processo Comercial N. }{ }^{\circ} 1709 / 2012-1\end{array}$ \\
\hline DADOS DO CONTRATANTE \\
\hline Contratante: Escola Politécnica - Usp \\
\hline CNPJ/CPF: 08.495.832/0001-38 \\
\hline Endereço: Avenida Prof. Luciano Gualberto, 158 Trav 3 - - São Paulo - SP CEP: 05.508-010 \\
\hline Contato: Juliana Alencar Telefone: (11) \\
\hline
\end{tabular}

\section{DADOS DO SOLICITANTE}

\begin{tabular}{|l|}
\hline Solicitante: Escola Politécnica - Usp \\
\hline CNPJ/CPF: 08.495.832/0001-38 \\
\hline Endereço de coleta: Avenida Prof. Luciano Gualberto, 158 Trav 3 - - São Paulo - SP CEP: 05.508-010 \\
\hline Legislação ou norma: Sem Comparativo \\
\hline
\end{tabular}

\section{DADOS OBTIDOS EM CAMPO}

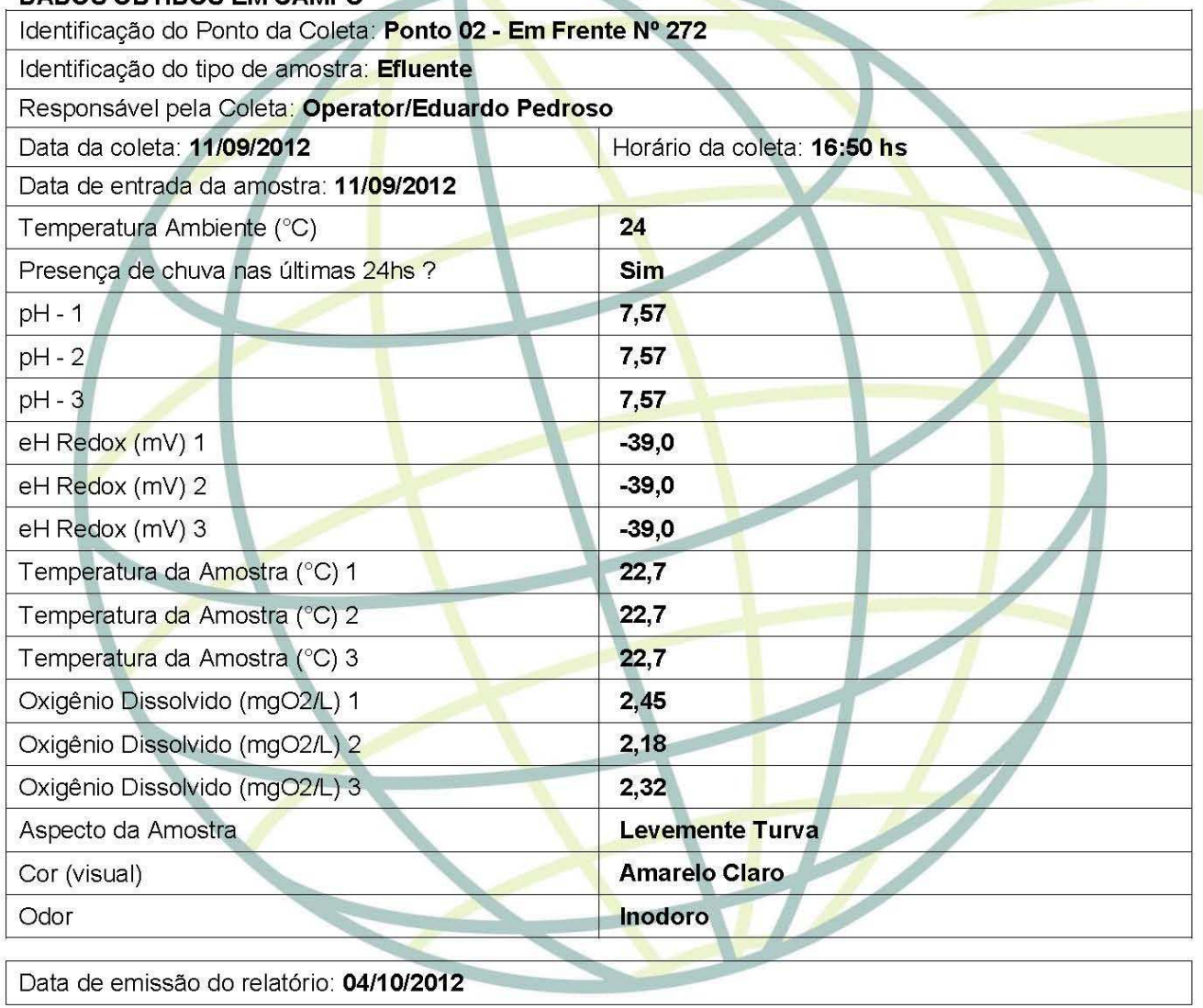


Cotia - SP, Rua Itafarma, 88 Jardim do Rio Cotia - CEP 06715-795

Tel.: (11) 5097.2249 - Fax: (11) 5097.2240

e-mail: comercialsp@operatorlab.com.br

Volta Redonda - RJ, Av. Sete de

Setembro, 449 - Aterrado - CEP 27213-310

Tel.: (24) 3337.4220 - Fax: (24) 3337.9832

e-mail: comercialvr@operatorlab.com.br

\begin{tabular}{|c|c|c|c|c|c|c|}
\hline \multicolumn{7}{|c|}{ RESULTADOS ANALÍTICOS } \\
\hline \multicolumn{7}{|c|}{ PARÂMETROS A SEGUIR NÃO SÃO ACREDITADOS ISO/IEC ABNT NBR ISO/IEC 17025:2005 } \\
\hline \multicolumn{7}{|l|}{ Parâmetro } \\
\hline Parâmetros & Unidade & LQ & Resultados & $\begin{array}{c}\text { Incerteza } \\
( \pm)\end{array}$ & $\begin{array}{c}\text { Data de } \\
\text { Realização }\end{array}$ & M \\
\hline Nitrogênio Kjedahl Total & $\mathrm{mg} / \mathrm{L}$ & 0,08 & 8,46 & 0,01 & $01 / 10 / 2012$ & 52 \\
\hline Diclorometano & $\mu g / L$ & 2,00 & $<2,00$ & 0,20 & $13 / 09 / 2012$ & 128 \\
\hline
\end{tabular}

RECUPERAÇÃO DOS SURROGATES

14655/2012 - Efluente - Ponto 02 - Em Frente No 272

\begin{tabular}{|l|c|c|c|}
\hline Parâmetros & Unidade & LQ & Resultado \\
\hline Itrio & $\%$ & 0 & $\mathbf{8 7}$ \\
\hline p-Bromofluorbenzeno & $\%$ & 0,05 & $\mathbf{1 0 4 , 4 1}$ \\
\hline Tolueno-d8 & $\%$ & 0,05 & $\mathbf{8 9 , 8 3}$ \\
\hline 2-Fluorobifenil & $\%$ & 0,05 & $\mathbf{1 0 2 , 5 6}$ \\
\hline p-Terfenil d14 & $\%$ & 0,05 & $\mathbf{8 9 , 9 9}$ \\
\hline
\end{tabular}

L.D - Limite de Deteç̧ão

Notas:

(1) Os resultados referem-se somente a amostra analisada.

(2) Plano de Amostragem / identificação dos pontos a serem amostrados é de responsabilidade do cliente.

(3) Todas as análises foram realizadas dentro dos prazos de validade da amostra, conforme indicado nas normas: SMEWW 21 st Ed; EPA; NBR; ASTM; CETESB; INEA e normas técnicas vigentes e descritas nas instruções operacionais padrão de Coleta e Preservação de Amostras da OPERATOR.

(4) Os dados brutos obtidos na execução das análises estão à disposição, podendo ser solicitado a qualquer momento.

(5) A interpretação dos resultados leva em consideração a incerteza de medição do ensaio.

(6) As incertezas apresentadas nos boletins de análise são referente à incerteza expandida dos métodos analíticos.

M Métodos de Referência

52 Nitrogênio Kjeldahl Total: SMEWW 4500 - Norg B Macro-Kjeldahl Method // SMEWW 4500 NH3 - D - Ammonia-Selective Electrode Method

USEPA SW 846 - Method $8021 \mathrm{~B}$ - Aromatic and halogenated volatiles by gas chromatography using photo ionization and/or eletrolytic conductivity detectors 


\section{Operattor}

Cotia - SP, Rua Itafarma, 88

Jardim do Rio Cotia - CEP 06715-795

Tel.: (11) 5097.2249 - Fax: (11) 5097.2240

e-mail: comercialsp@operatorlab.com.br

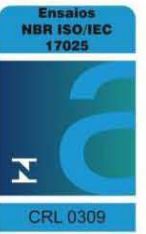

\begin{tabular}{|c|}
\hline $\begin{array}{l}\text { BOLETIM DE ANÁLISE N. } .^{\circ} 14656 / 2012-1.0 \\
\text { Processo Comercial N. }{ }^{\circ} 1709 / 2012-1\end{array}$ \\
\hline DADOS DO CONTRATANTE \\
\hline Contratante: Escola Politécnica - Usp \\
\hline CNPJ/CPF: 08.495.832/0001-38 \\
\hline Endereço: Avenida Prof. Luciano Gualberto, 158 Trav 3 - - São Paulo - SP CEP: 05.508-010 \\
\hline
\end{tabular}

DADOS DO SOLICITANTE

Solicitante: Escola Politécnica - Usp

CNPJ/CPF: 08.495.832/0001-38

Endereço de coleta: Avenida Prof. Luciano Gualberto, 158 Trav 3 - - São Paulo - SP CEP: 05.508-010

Legislação ou norma: Sem Comparativo

DADOS OBTIDOS EM CAMPO

Identificação do Ponto da Coleta: Ponto 01 - Rua Joaquim Maciel 80

Identificação do tipo de amostra: Efluente

Responsável pela Coleta: Operator/Eduardo Pedroso

\begin{tabular}{|l|l}
\hline Data da coleta: 11/09/2012 & Horário da coleta: 18:30 hs
\end{tabular}

Data de entrada da amostra: 11/09/2012

Temperatura Ambiente $\left({ }^{\circ} \mathrm{C}\right)$

Presença de chuva nas últimas $24 \mathrm{hs}$ ?

$\mathrm{pH}-1$

\begin{tabular}{|l|l|l|}
\hline $\mathrm{pH}-2$ & $\mathbf{7 , 4 2}$ \\
\hline
\end{tabular}

$\mathrm{pH}-3$

eH Redox (mV) 1

eH Redox (mV) 2

eH Redox (mV) 3

Temperatura da Amostra $\left({ }^{\circ} \mathrm{C}\right) 1$

Temperatura da Amostra $\left({ }^{\circ} \mathrm{C}\right) 2$

Temperatura da Amostra $\left({ }^{\circ} \mathrm{C}\right) 3$

Oxigênio Dissolvido (mgO2/L) 1

Oxigênio Dissolvido (mgO2/L) 2

Oxigênio Dissolvido ( $\mathrm{mgO} / \mathrm{L}) 3$

.

Aspecto da Amostra

Cor (visual)

Odor

\begin{tabular}{|l|}
\hline 24 \\
\hline Sim \\
\hline 7,42 \\
\hline 7,42 \\
\hline 7,42 \\
\hline$-35,0$ \\
\hline$-35,0$ \\
\hline$-35,0$ \\
\hline 21,9 \\
\hline 21,9 \\
\hline 21,9 \\
\hline 5,19 \\
\hline 5,18 \\
\hline 5,20 \\
\hline Levemente Turva \\
\hline Amarelo Claro \\
\hline Inodoro \\
\hline
\end{tabular}

Data de emissão do relatório: 04/10/2012 
Cotia - SP, Rua Itafarma, 88 Jardim do Rio Cotia - CEP 06715-795 Tel.: (11) 5097.2249 - Fax: (11) 5097.2240 e-mail: comercialsp@operatorlab.com.br

\begin{tabular}{|c|c|c|c|c|c|c|}
\hline \multicolumn{7}{|c|}{ RESULTADOS ANALÍTICOS } \\
\hline \multicolumn{7}{|c|}{ PARÂMETROS ACREDITADOS ISO/IEC ABNT NBR ISO/IEC 17025:2005 } \\
\hline \multicolumn{7}{|c|}{ Parâmetro } \\
\hline Parâmetros & Unidade & LQ & Resultados & $\begin{array}{l}\text { Incerteza } \\
( \pm)\end{array}$ & $\begin{array}{c}\text { Data de } \\
\text { Realizaçäo }\end{array}$ & m \\
\hline DBO & $\mathrm{mg} / \mathrm{L}$ & 2 & 4 & 1 & $12 / 09 / 2012$ & 61 \\
\hline Oxigênio Dissolvido & $\mathrm{mg} / \mathrm{L}$ & 0,50 & 5,19 & 000 & $12 / 09 / 2012$ & 110 \\
\hline Turbidez & NTU & 0,03 & 1,54 & 0,09 & $14 / 09 / 2012$ & 60 \\
\hline $\mathrm{pH}$ & --- & 0,10 & 7,42 & 0 & $12 / 09 / 2012$ & 30 \\
\hline Sólidos Dissolvidos Totais & $\mathrm{mg} / \mathrm{L}$ & 5 & 209 & 1 & $27 / 09 / 2012$ & 64 \\
\hline Nitrato & $\mathrm{mg} / \mathrm{L}$ & 0,07 & 5,81 & 0,009 & $12 / 09 / 2012$ & 35 \\
\hline Nitrogênio Amoniacal & $\mathrm{mg} / \mathrm{L}$ & 0,08 & 4,27 & 0,01 & $01 / 10 / 2012$ & 50 \\
\hline Alcalinidade Total & $\mathrm{mg} / \mathrm{L}$ & 5 & 67 & 5 & $27 / 09 / 2012$ & 32 \\
\hline Temperatura & ${ }^{\circ} \mathrm{C}$ & 1,0 & 21,9 & 0,15 & $12 / 09 / 2012$ & 58 \\
\hline Fósforo Total & $\mathrm{mg} / \mathrm{L}$ & 0,0200 & 0,178 & 0,0023 & $18 / 09 / 2012$ & 75 \\
\hline $\mathrm{DQO}$ & $\mathrm{mg} / \mathrm{L}$ & 5 & 27 & 1 & $17 / 09 / 2012$ & 62 \\
\hline Alumínio Dissolvido & $\mathrm{mg} / \mathrm{L}$ & 0,005 & 0,098 & 0,0005 & $19 / 09 / 2012$ & 47 \\
\hline Cobre Dissolvido & $\mathrm{mg} / \mathrm{L}$ & 0,0017 & 0,011 & 0,00005 & $19 / 09 / 2012$ & 47 \\
\hline Ferro Dissolvido & $\mathrm{mg} / \mathrm{L}$ & 0,002 & 0,092 & 0,0005 & $19 / 09 / 2012$ & 47 \\
\hline Mercúrio Total & $\mathrm{mg} / \mathrm{L}$ & 0,00010 & $<0,00010$ & 0,00003 & $18 / 09 / 2012$ & 75 \\
\hline Antimônio & $\mathrm{mg} / \mathrm{L}$ & 0,0020 & 0,004 & 0,0005 & $18 / 09 / 2012$ & 75 \\
\hline Arsênio Total & $\mathrm{mg} / \mathrm{L}$ & 0,0020 & $<0,0020$ & 0,0005 & $18 / 09 / 2012$ & 75 \\
\hline Bário Total & $\mathrm{mg} / \mathrm{L}$ & 0,0017 & 0,066 & 0,0001 & $18 / 09 / 2012$ & 75 \\
\hline Berilio Total & $\mathrm{mg} / \mathrm{L}$ & 0,0060 & $<0,0060$ & 0,0003 & $18 / 09 / 2012$ & 75 \\
\hline Boro Total & $\mathrm{mg} / \mathrm{L}$ & 0,0520 & 0,054 & 0,0053 & $18 / 09 / 2012$ & 75 \\
\hline Cádmio Total & $\mathrm{mg} / \mathrm{L}$ & 0,0017 & $<0,0017$ & 0,0001 & $18 / 09 / 2012$ & 75 \\
\hline Chumbo Total & $\mathrm{mg} / \mathrm{L}$ & 0,0020 & $<0,0020$ & 0,0005 & $18 / 09 / 2012$ & 75 \\
\hline Cobalto Total & $\mathrm{mg} / \mathrm{L}$ & 0,0020 & $<0,0020$ & 0,0005 & $18 / 09 / 2012$ & 75 \\
\hline Cromo Total & $\mathrm{mg} / \mathrm{L}$ & 0,0060 & 0,007 & 0,0015 & $18 / 09 / 2012$ & 75 \\
\hline Lítio Total & $\mathrm{mg} / \mathrm{L}$ & 0,0270 & $<0,0270$ & 0,0125 & $18 / 09 / 2012$ & 75 \\
\hline Manganês Total & $\mathrm{mg} / \mathrm{L}$ & 0,0030 & 0,424 & 0,0005 & $18 / 09 / 2012$ & 75 \\
\hline Niquel Total & $\mathrm{mg} / \mathrm{L}$ & 0,0017 & $<0,0017$ & 0,0001 & $18 / 09 / 2012$ & 75 \\
\hline Prata Total & $\mathrm{mg} / \mathrm{L}$ & 0,0001 & $<0,0001$ & 0,0000 & $18 / 09 / 2012$ & 75 \\
\hline Selênio Total & $\mathrm{mg} / \mathrm{L}$ & 0,0030 & 0,005 & 0,0005 & $18 / 09 / 2012$ & 75 \\
\hline Vanádio Total & $\mathrm{mg} / \mathrm{L}$ & 0,0040 & $<0,0040$ & 0,0010 & $18 / 09 / 2012$ & 75 \\
\hline Zinco Total & $\mathrm{mg} / \mathrm{L}$ & 0,0011 & 0,013 & 0,0003 & $18 / 09 / 2012$ & 75 \\
\hline 2-Clorofenol & $\mu g / L$ & 0,010 & $<0,010$ & 0.001 & $13 / 09 / 2012$ & 12 \\
\hline 1,2-Dicloroetano & $\mu \mathrm{g} / \mathrm{L}$ & 2,00 & $<2,00$ & 0,20 & $13 / 09 / 2012$ & 128 \\
\hline 1,1-Dicloroeteno & $\mu \mathrm{g} / \mathrm{L}$ & 2,00 & $<2,00$ & 0,20 & $13 / 09 / 2012$ & 128 \\
\hline
\end{tabular}




\section{Operattor ${ }^{\circ}$}

Cotia - SP, Rua Itafarma, 88

Jardim do Rio Cotia - CEP 06715-795

Tel.: (11) 5097.2249 - Fax: (11) 5097.2240

e-mail: comercialsp@operatorlab.com.br

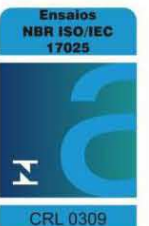

Parâmetro
\begin{tabular}{|l|c|c|c|c|c|c|}
\hline Parâmetros & Unidade & LQ & Resultados & $\begin{array}{c}\text { Incerteza } \\
(\mathbf{\pm})\end{array}$ & $\begin{array}{c}\text { Data de } \\
\text { Realização }\end{array}$ & M \\
\hline Estireno & $\mu \mathrm{g} / \mathrm{L}$ & 2,00 & $<\mathbf{2 , 0 0}$ & 0,20 & $13 / 09 / 2012$ & 128 \\
\hline Tetracloreto de Carbono & $\mu \mathrm{g} / \mathrm{L}$ & 1,00 & $<\mathbf{1 , 0 0}$ & 0,10 & $13 / 09 / 2012$ & 128 \\
\hline Tetracloroeteno & $\mu \mathrm{g} / \mathrm{L}$ & 2,00 & $<\mathbf{2 , 0 0}$ & 0,20 & $13 / 09 / 2012$ & 128 \\
\hline Triclorobenzenos & $\mu \mathrm{g} / \mathrm{L}$ & 0,07 & $<\mathbf{0 , 0 7}$ & 0,03 & $13 / 09 / 2012$ & 128 \\
\hline Tricloroeteno & $\mu \mathrm{g} / \mathrm{L}$ & 0,10 & $<\mathbf{0 , 1 0}$ & 0,03 & $13 / 09 / 2012$ & 128 \\
\hline Benzeno & $\mu \mathrm{g} / \mathrm{L}$ & 2,00 & $<\mathbf{2 , 0 0}$ & 0,13 & $13 / 09 / 2012$ & 128 \\
\hline Etilbenzeno & $\mu \mathrm{g} / \mathrm{L}$ & 2,00 & $<\mathbf{2 , 0 0}$ & 0,16 & $13 / 09 / 2012$ & 128 \\
\hline Tolueno & $\mu \mathrm{g} / \mathrm{L}$ & 2,00 & $<\mathbf{2 , 0 0}$ & 0,16 & $13 / 09 / 2012$ & 128 \\
\hline Xilenos & $\mu \mathrm{g} / \mathrm{L}$ & 2,00 & $<\mathbf{2 , 0 0}$ & 0,20 & $13 / 09 / 2012$ & 128 \\
\hline Oleos e Graxas & $\mathrm{mg} / \mathrm{L}$ & 5 & $<\mathbf{5}$ & 0,1 & $17 / 09 / 2012$ & 46 \\
\hline
\end{tabular}

RECUPERAÇÃO DOS SURROGATES

14656/2012 - Efluente - Ponto 01 - Rua Joaquim Maciel 80

\begin{tabular}{|l|c|c|c|}
\hline Parâmetros & Unidade & LQ & Resultado \\
\hline Itrio & $\%$ & 0 & $\mathbf{9 0}$ \\
\hline p-Bromofluorbenzeno & $\%$ & 0,05 & $\mathbf{9 0 , 5 2}$ \\
\hline Tolueno-d8 & $\%$ & 0,05 & $\mathbf{8 3 , 3 1}$ \\
\hline 2-Fluorobifenil & $\%$ & 0,05 & $\mathbf{8 7 , 1 3}$ \\
\hline p-Terfenil d14 & $\%$ & 0,05 & $\mathbf{9 9 , 6 9}$ \\
\hline
\end{tabular}

L.D - Limite de Deteç̧ão

Notas:

(1) Os resultados referem-se somente a amostra analisada.

(2) Plano de Amostragem / identificação dos pontos a serem amostrados é de responsabilidade do cliente.

(3) Todas as análises foram realizadas dentro dos prazos de validade da amostra, conforme indicado nas normas: SMEWW 21 st Ed.; EPA; NBR; ASTM; CETESB; INEA e normas técnicas vigentes e descritas nas instruções operacionais padrão de Coleta e Preservação de Amostras da OPERATOR.

(4) Os dados brutos obtidos na execução das análises estão à disposição, podendo ser solicitado a qualquer momento.

(5) A interpretação dos resultados leva em consideração a incerteza de medição do ensaio.

(6) As incertezas apresentadas nos boletins de análise são referente à incerteza expandida dos métodos analíticos.

Métodos de Referência

USEPA SW 846 - Method 8270 D - Semivolatile Organic Compounds by CG/MS rev 04 - Fev 2007

$\mathrm{pH}$ : SMEWW $4500-\mathrm{H}+$ - B - Eletrometric Method

Alcalinidade: SMEWW 21th Ed. 2320 - Alkalinity

Ânions: USEPA SW 846 - Method 300.1 - Determination of Inorganic Anions in Drinking Water by lon Chromatography

Óleos e Graxas: SMEMW 5520 - Oil and Grease

Metais: SMEWW 3120 B Inductively Coupled Plasma (ICP) Method 


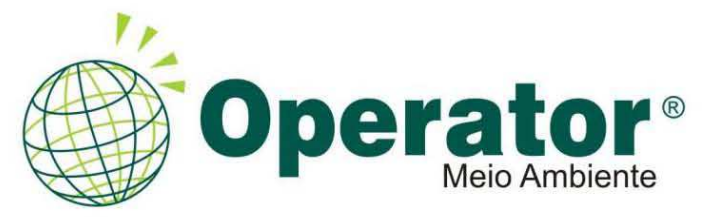

Cotia - SP, Rua Itafarma, 88

Jardim do Rio Cotia - CEP 06715-795
Tel.: (11) 5097.2249 - Fax: (11) 5097.2240

e-mail: comercialsp@operatorlab.com.br

50 Nitrogênio Amoniacal: SMEWW 4500 - NH3 - D - Ammonia-Selective Electrode Method

58 Temperatura: Leitura direta com Termohigrômetro

60 Turbidez: SMEWW 21th Ed. 2130 B - Nephelometric Method

61 DBO: SMEWw 21th Ed. 5210 B. Biochemical Oxygen Demand (BOD)

62 DQO: SMEWW 21th Ed. 5220 - D - Closed Reflux, Colorimetric Method

64 Sólidos Dissolvidos: SWEMM 2540 - C - Total Dissolved Solids Dried at $180^{\circ} \mathrm{C}$

75 USEPA SW 846 - Method 6010 C - Inductivily Coupled Plasma Atomic Emission Espectrometry

110 Oxigênio Dissolvido: SMEMN 4500 - O - Oxygen (Dissolved)

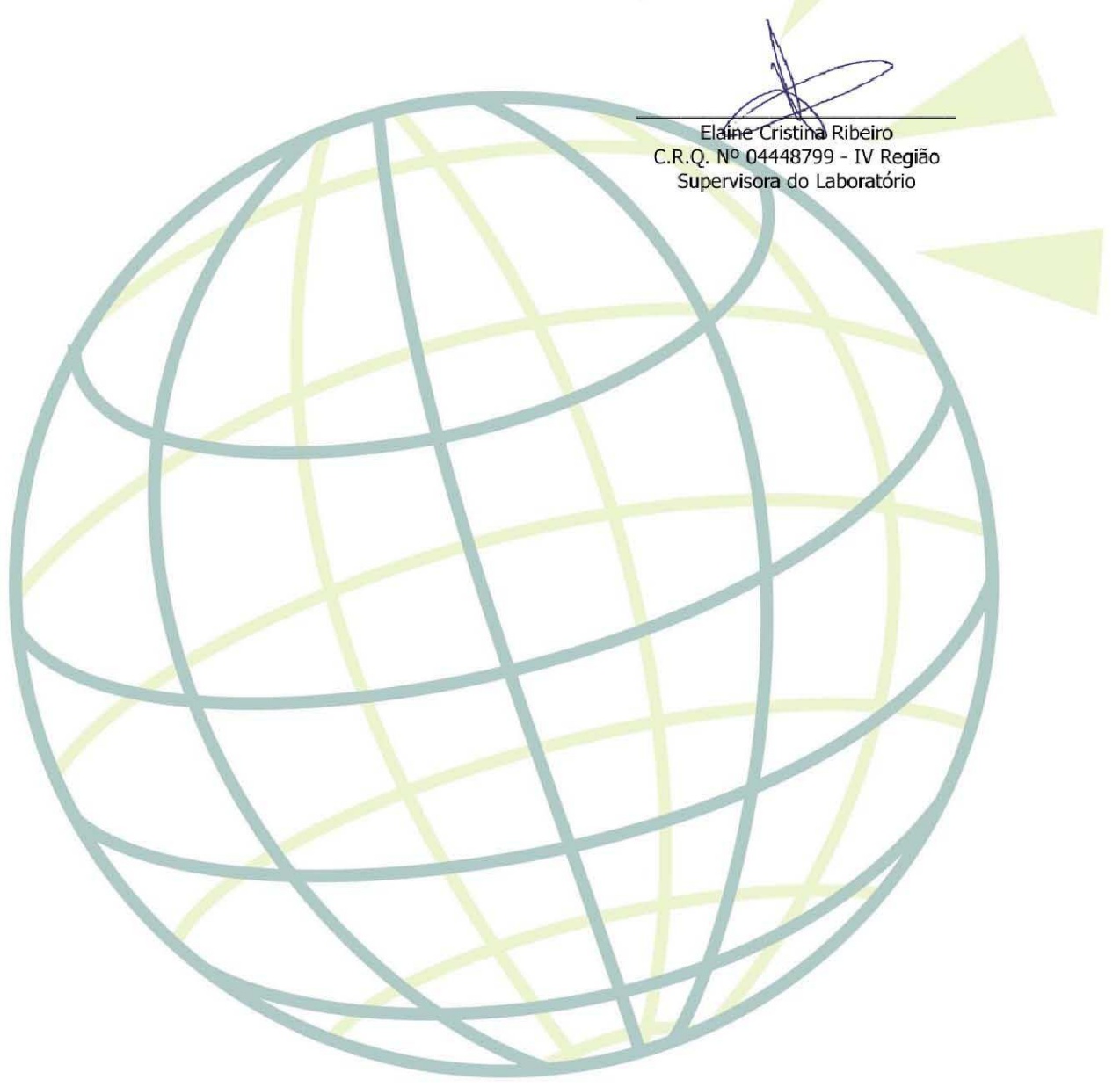

Página 4 de 4 / B.A. 14656/2012 - 1.0 Ponto 01 - Rua Joaquim Maciel 80 


\section{Operator}

Cotia - SP Rua Itafarma, 88

Jardim do Rio Cotia - CEP 06715-795

Tel.: (11) 5097.2249 - Fax: (11) 5097.2240

e-mail: comercialsp@operatorlab.com.br

Volta Redonda - RJ, Av. Sete de

Setembro, 449 - Aterrado - CEP 27213-310

Tel.: (24) 3337.4220 - Fax: (24) 3337.9832

e-mail: comercialvr@operatorlab.com.br

\begin{tabular}{|c|}
\hline $\begin{array}{l}\text { BOLETIM DE ANÁLISE N. } .^{\circ} 14656 / 2012-1.0 \\
\text { Processo Comercial N. }{ }^{\circ} 1709 / 2012-1\end{array}$ \\
\hline DADOS DO CONTRATANTE \\
\hline Contratante: Escola Politécnica - Usp \\
\hline CNPJ/CPF: 08.495.832/0001-38 \\
\hline Endereço: Avenida Prof. Luciano Gualberto, 158 Trav 3 - - São Paulo - SP CEP: 05.508-010 \\
\hline Contato: Juliana Alencar Telefone: (11) \\
\hline
\end{tabular}

\section{DADOS DO SOLICITANTE}

\begin{tabular}{|l|}
\hline Solicitante: Escola Politécnica - Usp \\
\hline CNPJ/CPF: 08.495.832/0001-38 \\
\hline Endereço de coleta: Avenida Prof. Luciano Gualberto, 158 Trav 3 - - São Paulo - SP CEP: 05.508-010 \\
\hline Legislação ou norma: Sem Comparativo \\
\hline
\end{tabular}

\section{DADOS OBTIDOS EM CAMPO}

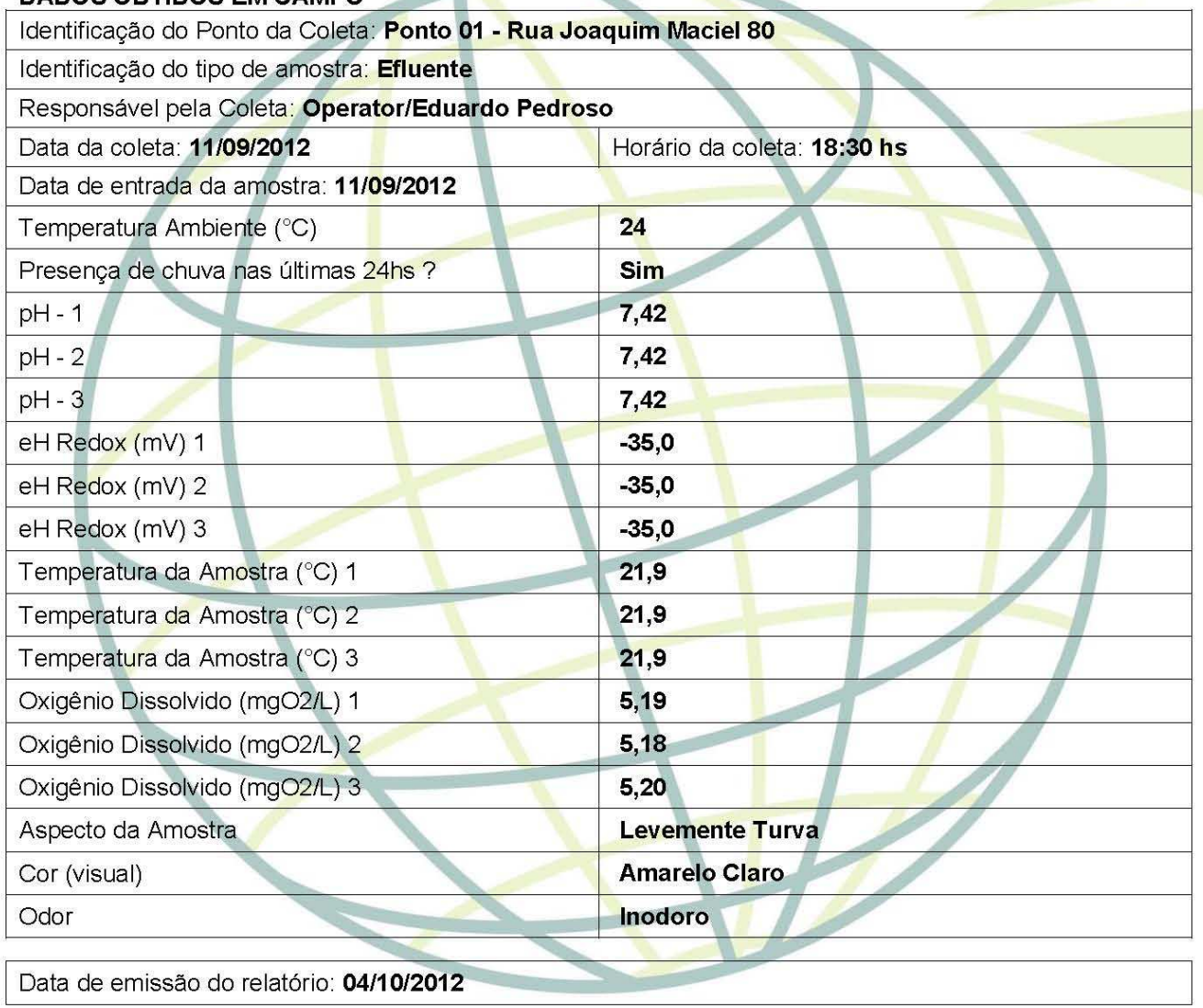




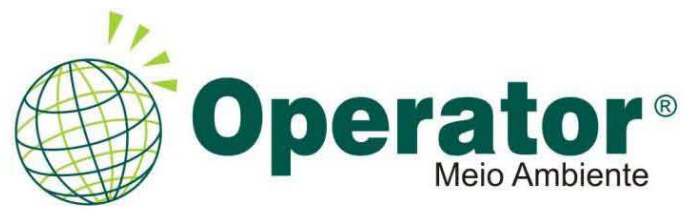

Cotia - SP, Rua Itafarma, 88 Jardim do Rio Cotia - CEP 06715-795

Tel.: (11) 5097.2249 - Fax: (11) 5097.2240

e-mail: comercialsp@operatorlab.com.br

Volta Redonda - RJ, Av. Sete de

Setembro, 449 - Aterrado - CEP 27213-310

Tel.: (24) 3337.4220 - Fax: (24) 3337.9832

e-mail: comercialvr@operatorlab.com.br

\section{RESULTADOS ANALÍTICOS}

PARÂMETROS A SEGUIR NÃO SÃO ACREDITADOS ISO/IEC ABNT NBR ISO/IEC 17025:2005

Parâmetro

\begin{tabular}{|l|c|c|c|c|c|c|}
\hline Parâmetros & Unidade & LQ & Resultados & $\begin{array}{c}\text { Incerteza } \\
( \pm)\end{array}$ & $\begin{array}{c}\text { Data de } \\
\text { Realização }\end{array}$ & M \\
\hline Nitrogênio Kjedahl Total & $\mathrm{mg} / \mathrm{L}$ & 0,08 & 4,95 & 0,01 & $01 / 10 / 2012$ & 52 \\
\hline Diclorometano & $\mu \mathrm{g} / \mathrm{L}$ & 2,00 & $<\mathbf{2 , 0 0}$ & 0,20 & $13 / 09 / 2012$ & 128 \\
\hline
\end{tabular}

RECUPERAÇÃO DOS SURROGATES

14656/2012 - Efluente - Ponto 01 - Rua Joaquim Maciel 80

\begin{tabular}{|l|c|c|c|}
\hline Parâmetros & Unidade & LQ & Resultado \\
\hline Itrio & $\%$ & 0 & $\mathbf{9 0}$ \\
\hline p-Bromofluorbenzeno & $\%$ & 0,05 & $\mathbf{9 0 , 5 2}$ \\
\hline Tolueno-d8 & $\%$ & 0,05 & $\mathbf{8 3 , 3 1}$ \\
\hline 2-Fluorobifenil & $\%$ & 0,05 & $\mathbf{8 7 , 1 3}$ \\
\hline p-Terfenil d14 & $\%$ & 0,05 & $\mathbf{9 9 , 6 9}$ \\
\hline
\end{tabular}

L.D - Limite de Deteç̧ão

Notas:

(1) Os resultados referem-se somente a amostra analisada.

(2) Plano de Amostragem / identificação dos pontos a serem amostrados é de responsabilidade do cliente.

(3) Todas as análises foram realizadas dentro dos prazos de validade da amostra, conforme indicado nas normas: SMEWW 21 st Ed; EPA; NBR; ASTM; CETESB; INEA e normas tecnicas vigentes e descritas nas instruções operacionais padrão de Coleta e Preservação de Amostras da OPERATOR.

(4) Os dados brutos obtidos na execução das análises estão à disposição, podendo ser solicitado a qualquer momento.

(5) A interpretação dos resultados leva em consideração a incerteza de medição do ensaio.

(6) As incertezas apresentadas nos boletins de análise são referente à incerteza expandida dos métodos analíticos.

M Métodos de Referência

52 Nitrogênio Kjeldahl Total: SMEWW 4500 - Norg B Macro-Kjeldahl Method // SMEWW 4500 NH3 - D - Ammonia-Selective

52 Electrode Method

USEPA SW 840 - Method $8021 \mathrm{~B}$ - Aromatic and halogenated volatiles by gas chromatography using photo ionization and

128

USEPA SW 846 - Method 80218
eletrolytic conductivity detectors 


\section{Operattor}

Cotia - SP, Rua Itafarma, 88

Jardim do Rio Cotia - CEP 06715-795

Tel.: (11) 5097.2249 - Fax: (11) 5097.2240

e-mail: comercialsp@operatorlab.com.br

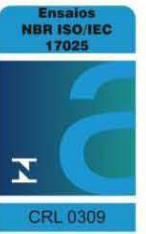

\begin{tabular}{|c|}
\hline $\begin{array}{l}\text { BOLETIM DE ANÁLISE N. }{ }^{\circ} \mathbf{1 3 5 5 / 2 0 1 3 - 1 . 0} \\
\text { Processo Comercial N. }{ }^{\circ} 1709 / 2012-1\end{array}$ \\
\hline DADOS DO CONTRATANTE \\
\hline Contratante: Escola Politécnica - Usp \\
\hline CNPJ/CPF: 08.495.832/0001-38 \\
\hline Endereço: Avenida Prof. Luciano Gualberto, 158 Trav 3 - - São Paulo - SP CEP: 05.508-010 \\
\hline
\end{tabular}

DADOS DO SOLICITANTE

Solicitante: Escola Politécnica - Usp

CNPJ/CPF: 08.495.832/0001-38

Endereço de coleta: Avenida Prof. Luciano Gualberto, 158 Trav 3 - - São Paulo - SP CEP: 05.508-010

Legislação ou norma: Sem Comparativo

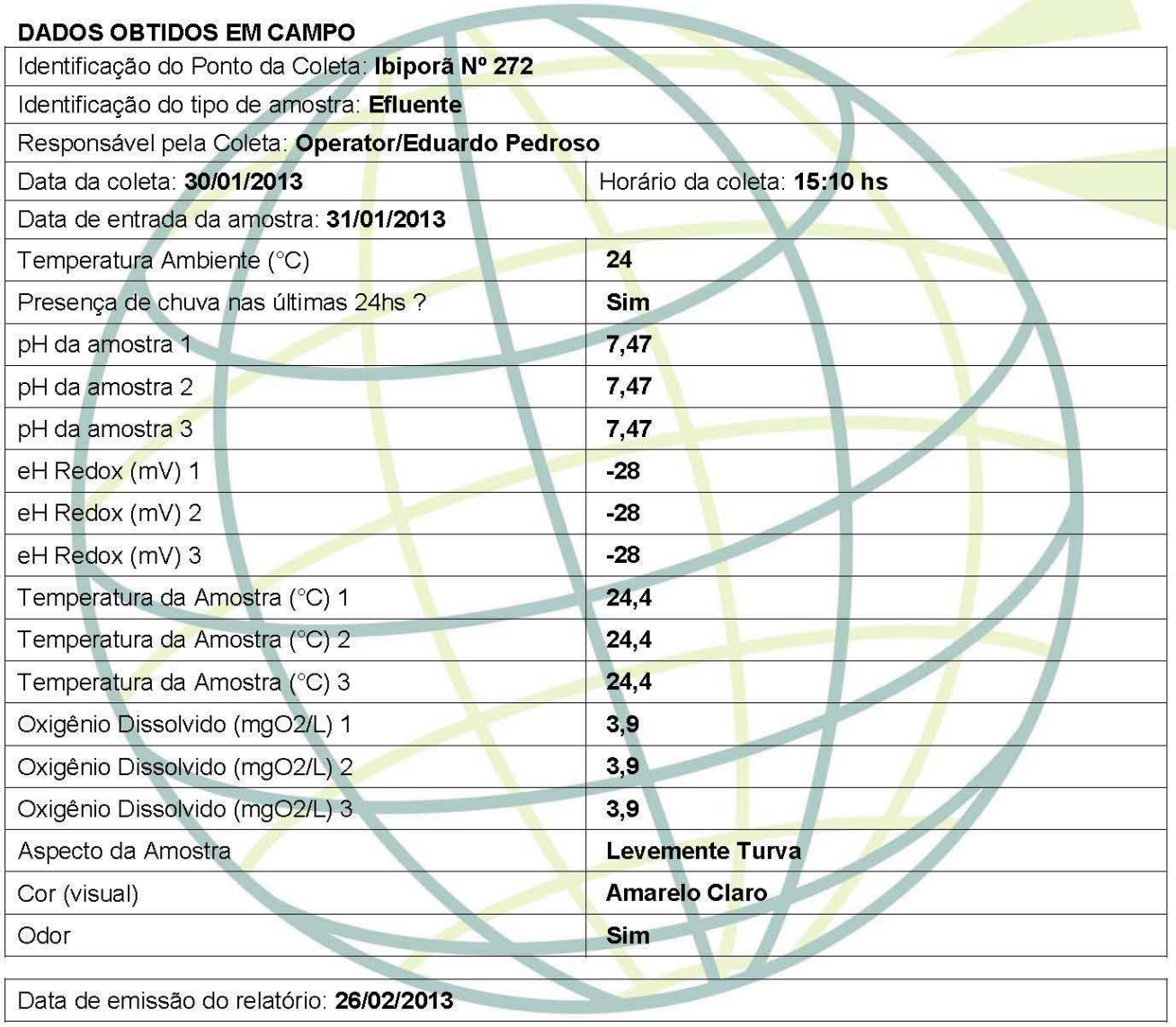

Página 1 de 4 / B.A. 1355/2013- 1.0 lbiporã $\mathrm{N}^{\circ} 272$ 
Cotia - SP, Rua Itafarma, 88

Jardim do Rio Cotia - CEP 06715-795

Tel.: (11) 5097.2249 - Fax: (11) 5097.2240

e-mail: comercialsp@operatorlab.com.br

\begin{tabular}{|c|c|c|c|c|c|c|}
\hline \multicolumn{7}{|c|}{ RESULTADOS ANALÍTICOS } \\
\hline \multicolumn{7}{|c|}{ PARÂMETROS ACREDITADOS ISO/IEC ABNT NBR ISO/IEC 17025:2005 } \\
\hline \multicolumn{7}{|l|}{ Parâmetro } \\
\hline Parâmetros & Unidade & LQ & Resultados & $\begin{array}{c}\text { Incerteza } \\
\text { (士) }\end{array}$ & $\begin{array}{c}\text { Data de } \\
\text { Realizaçäo }\end{array}$ & M \\
\hline DBO & $\mathrm{mg} / \mathrm{L}$ & 2 & 9 & 1 & $31 / 01 / 2013$ & 61 \\
\hline Oxigênio Dissolvido & $\mathrm{mg} / \mathrm{L}$ & 0,50 & 3,90 & 0,001 & $05 / 02 / 2013$ & 110 \\
\hline Turbidez & NTU & 0,03 & 10,80 & 0,65 & $31 / 01 / 2013$ & 60 \\
\hline $\mathrm{pH}$ & --- & 0,10 & 7,47 & 0,03 & $31 / 01 / 2013$ & 30 \\
\hline Nitrato & $\mathrm{mg} / \mathrm{L}$ & 0,07 & 1,75 & 0,009 & $31 / 01 / 2013$ & 35 \\
\hline Nitrogênio Amoniacal & $\mathrm{mg} / \mathrm{L}$ & 0,08 & 1,42 & -- & $13 / 02 / 2013$ & 50 \\
\hline Alcalinidade Total & $\mathrm{mg} / \mathrm{L}$ & 5 & 72 & 5 & $05 / 02 / 2013$ & 32 \\
\hline Temperatura & ${ }^{\circ} \mathrm{C}$ & 1,0 & 24,4 & 0,15 & $05 / 02 / 2013$ & 58 \\
\hline Fósforo Total & $\mathrm{mg} / \mathrm{L}$ & 3,6000 & $<3,6000$ & --- & $26 / 02 / 2013$ & 75 \\
\hline DQO & $\mathrm{mg} / \mathrm{L}$ & 5 & 22 & 1 & $04 / 02 / 2013$ & 62 \\
\hline Alumínio Dissolvido & $\mathrm{mg} / \mathrm{L}$ & 0,005 & 0,015 & 0,0005 & $26 / 02 / 2013$ & 75 \\
\hline Cobre Dissolvido & $\mathrm{mg} / \mathrm{L}$ & 0,0017 & 0,002 & 0,00005 & $26 / 02 / 2013$ & 75 \\
\hline Ferro Dissolvido & $\mathrm{mg} / \mathrm{L}$ & 0,002 & 0,126 & 0,0005 & $26 / 02 / 2013$ & 75 \\
\hline Mercúrio Total & $\mathrm{mg} / \mathrm{L}$ & 0,00010 & $<0,00010$ & 0,00003 & $26 / 02 / 2013$ & 75 \\
\hline Antimônio & $\mathrm{mg} / \mathrm{L}$ & 0,002 & $<0,002$ & 0,0005 & $26 / 02 / 2013$ & 75 \\
\hline Arsênio Total & $\mathrm{mg} / \mathrm{L}$ & 0,002 & $<0,002$ & 0,0005 & $26 / 02 / 2013$ & 75 \\
\hline Bário Total & $\mathrm{mg} / \mathrm{L}$ & 0,0017 & 0,0805 & 0,00005 & $26 / 02 / 2013$ & 75 \\
\hline Berílio Total & $\mathrm{mg} / \mathrm{L}$ & 0,006 & $<0,006$ & 0,0003 & $26 / 02 / 2013$ & 75 \\
\hline Boro Total & $\mathrm{mg} / \mathrm{L}$ & 0,052 & $<0,052$ & 0,0053 & $26 / 02 / 2013$ & 75 \\
\hline Cádmio Total & $\mathrm{mg} / \mathrm{L}$ & 0,0017 & $<0,0017$ & 0,00005 & $26 / 02 / 2013$ & 75 \\
\hline Chumbo Total & $\mathrm{mg} / \mathrm{L}$ & 0,002 & 0,003 & 0,0005 & $26 / 02 / 2013$ & 75 \\
\hline Cobalto Total & $\mathrm{mg} / \mathrm{L}$ & 0,002 & $<0,002$ & 0,0005 & $26 / 02 / 2013$ & 75 \\
\hline Cromo Total & $\mathrm{mg} / \mathrm{L}$ & 0,006 & $<0,006$ & 0,0015 & $26 / 02 / 2013$ & 75 \\
\hline Lítio Total & $\mathrm{mg} / \mathrm{L}$ & 0,027 & $<0,027$ & 0,0125 & $26 / 02 / 2013$ & 75 \\
\hline Manganês Total & $\mathrm{mg} / \mathrm{L}$ & 0,003 & 0,145 & 0,0005 & $26 / 02 / 2013$ & 75 \\
\hline Niquel Total & $\mathrm{mg} / \mathrm{L}$ & 0,0017 & $<0,0017$ & 0,00005 & $26 / 02 / 2013$ & 75 \\
\hline Prata Total & $\mathrm{mg} / \mathrm{L}$ & 0,00010 & $<0,00010$ & 0,00004 & $26 / 02 / 2013$ & 75 \\
\hline Selênio Total & $\mathrm{mg} / \mathrm{L}$ & 0,003 & $<0,003$ & 0,0005 & $26 / 02 / 2013$ & 75 \\
\hline Vanádio Total & $\mathrm{mg} / \mathrm{L}$ & 0,004 & $<0,004$ & 0,0010 & $26 / 02 / 2013$ & 75 \\
\hline Zinco Total & $\mathrm{mg} / \mathrm{L}$ & 0,0011 & 0,0178 & 0,0003 & $26 / 02 / 2013$ & 75 \\
\hline 2-Clorofenol & $\mu \mathrm{g} / \mathrm{L}$ & 0,010 & $<0,010$ & 0,001 & $04 / 02 / 2013$ & 12 \\
\hline 1,2-Dicloroetano & $\mu g / L$ & 2,00 & $<2,00$ & 0,20 & $31 / 01 / 2013$ & 128 \\
\hline 1,1-Dicloroeteno & $\mu \mathrm{g} / \mathrm{L}$ & 2,00 & $<2,00$ & 0,20 & $31 / 01 / 2013$ & 128 \\
\hline Estireno & $\mu \mathrm{g} / \mathrm{L}$ & 2,00 & $<2,00$ & 0,20 & $31 / 01 / 2013$ & 128 \\
\hline
\end{tabular}


Cotia - SP, Rua Itafarma, 88

Jardim do Rio Cotia - CEP 06715-795

Tel.: (11) 5097.2249 - Fax: (11) 5097.2240

e-mail: comercialsp@operatorlab.com.br

\begin{tabular}{|c|c|c|c|c|c|c|}
\hline \multicolumn{7}{|l|}{ Parâmetro } \\
\hline Parâmetros & Unidade & LQ & Resultados & $\begin{array}{c}\text { Incerteza } \\
( \pm)\end{array}$ & $\begin{array}{c}\text { Data de } \\
\text { Realização }\end{array}$ & M \\
\hline Tetracloreto de Carbono & $\mu g / L$ & 2,00 & $<2,00$ & 0,20 & $31 / 01 / 2013$ & 128 \\
\hline Tetracloroeteno & $\mu g / L$ & 2,00 & $<2,00$ & 0,20 & $31 / 01 / 2013$ & 128 \\
\hline Triclorobenzenos & $\mu g / L$ & 2,00 & $<2,00$ & 0,20 & $31 / 01 / 2013$ & 128 \\
\hline Tricloroeteno & $\mu g / L$ & 2,00 & $<2,00$ & 0,20 & $31 / 01 / 2013$ & 128 \\
\hline Benzeno & $\mu g / L$ & 2,00 & $<2,00$ & 0,20 & $31 / 01 / 2013$ & 128 \\
\hline Etilbenzeno & $\mu g / L$ & 2,00 & $<2,00$ & 0,20 & $31 / 01 / 2013$ & 128 \\
\hline Tolueno & $\mu g / L$ & 2,00 & $<2,00$ & 0,20 & $31 / 01 / 2013$ & 128 \\
\hline Xilenos & $\mu g / L$ & 2,00 & $<2,00$ & 0,20 & $31 / 01 / 2013$ & 128 \\
\hline Diclorometano & $\mu g / L$ & 2,00 & $<2,00$ & 0,20 & $31 / 01 / 2013$ & 128 \\
\hline Óleos e Graxas & $\mathrm{mg} / \mathrm{L}$ & 5 & 8 & 0,4 & $04 / 02 / 2013$ & 46 \\
\hline Sólidos Dissolvidos Totais & $\mathrm{mg} / \mathrm{L}$ & 2 & 214 & 0,5 & $04 / 02 / 2013$ & 5 \\
\hline
\end{tabular}

RECUPERAÇÃO DOS SURROGATES

1355/2013 - Efluente - Ibiporã No 272

\begin{tabular}{|l|c|c|c|}
\hline Parâmetros & Unidade & LQ & Resultado \\
\hline Itrio & $\%$ & 0,1 & $\mathbf{8 1 , 8}$ \\
\hline p-Bromofluorbenzeno & $\%$ & 0,05 & $\mathbf{1 1 1 , 5 2}$ \\
\hline Tolueno-d8 & $\%$ & 0,05 & $\mathbf{8 8 , 6 0}$ \\
\hline 2-Fluorobifenil & $\%$ & 0,05 & 77,87 \\
\hline p-Terfenil d14 & $\%$ & 0,05 & $\mathbf{9 2 , 7 3}$ \\
\hline
\end{tabular}

L.D - Limite de Detecção

L.Q- Limite de Quantificação

(๕) Abaixo do Limite de Deteç̧ão

Notas:

(1) Os resultados referem-se somente a amostra analisada.

(2) Plano de Amostragem / identificação dos pontos a serem amostrados é de responsabilidade do cliente.

(3) Todas as análises foram realizadas dentro dos prazos de validade da amostra, conforme indicado nas normas: SMEWW 21 st Ed.; EPA; NBR; ASTM; CETESB; INEA e normas técnicas vigentes e descritas nas instruções operacionais padrão de Coleta e Preservação de Amostras da OPERATOR.

(4) Os dados brutos obtidos na execução das análises estão à disposição, podendo ser solicitado a qualquer momento.

(5) A interpretação dos resultados leva em consideração a incerteza de medição do ensaio.

(6) As incertezas apresentadas nos boletins de análise são referente à incerteza expandida dos métodos analíticos.

\section{Métodos de Referência}

Standard Methods 21 th Ed. - Part 2000 Physical and aggregate properties

USEPA SW 846 - Method 8270 D - Semivolatile Organic Compounds by CG/MS rev 04 - Fev 2007

SM22 4500-H B - Eletrometric Method

Alcalinidade: SMEWW 21th Ed. 2320 - Alkalinity

Ânions: USEPA SW 846 - Method 300.1 - Determination of Inorganic Anions in Drinking Water by lon Chromatography 


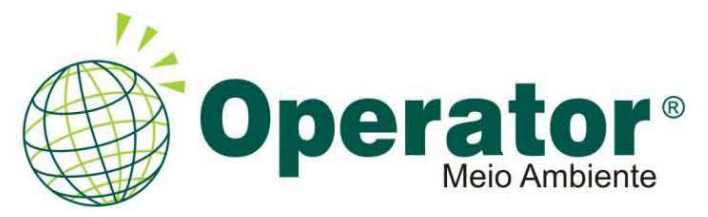

Cotia - SP, Rua Itafarma, 88

Jardim do Rio Cotia - CEP 06715-795
Tel.: (11) 5097.2249 - Fax: (11) 5097.2240

e-mail: comercialsp@operatorlab.com.br

46 Óleos e Graxas: SMEWW 5520 - Oil and Grease

50 SMWW 22nd ed., 2012 - Part 4500 D - Ammonia-Selective Electrode Method

58 Temperatura: Leitura direta com Termohigrômetro

60 Turbidez: SMEWW 21th Ed. 2130 B - Nephelometric Method

61 DBO: SMEWW 21th Ed. 5210 B. Biochemical Oxygen Demand (BOD)

62 DQO: SMEWW 21th Ed. 5220 - D - Closed Reflux, Colorimetric Method

75 USEPA SW 846 - Method $6010 \mathrm{C}$ - Inductivily Coupled Plasma Atomic Emission Espectrometry

110 Oxigênio Dissolvido: SMEMN 4500 - 0 - Oxygen (Dissolved)

128 eletrolytic conductivity detectors

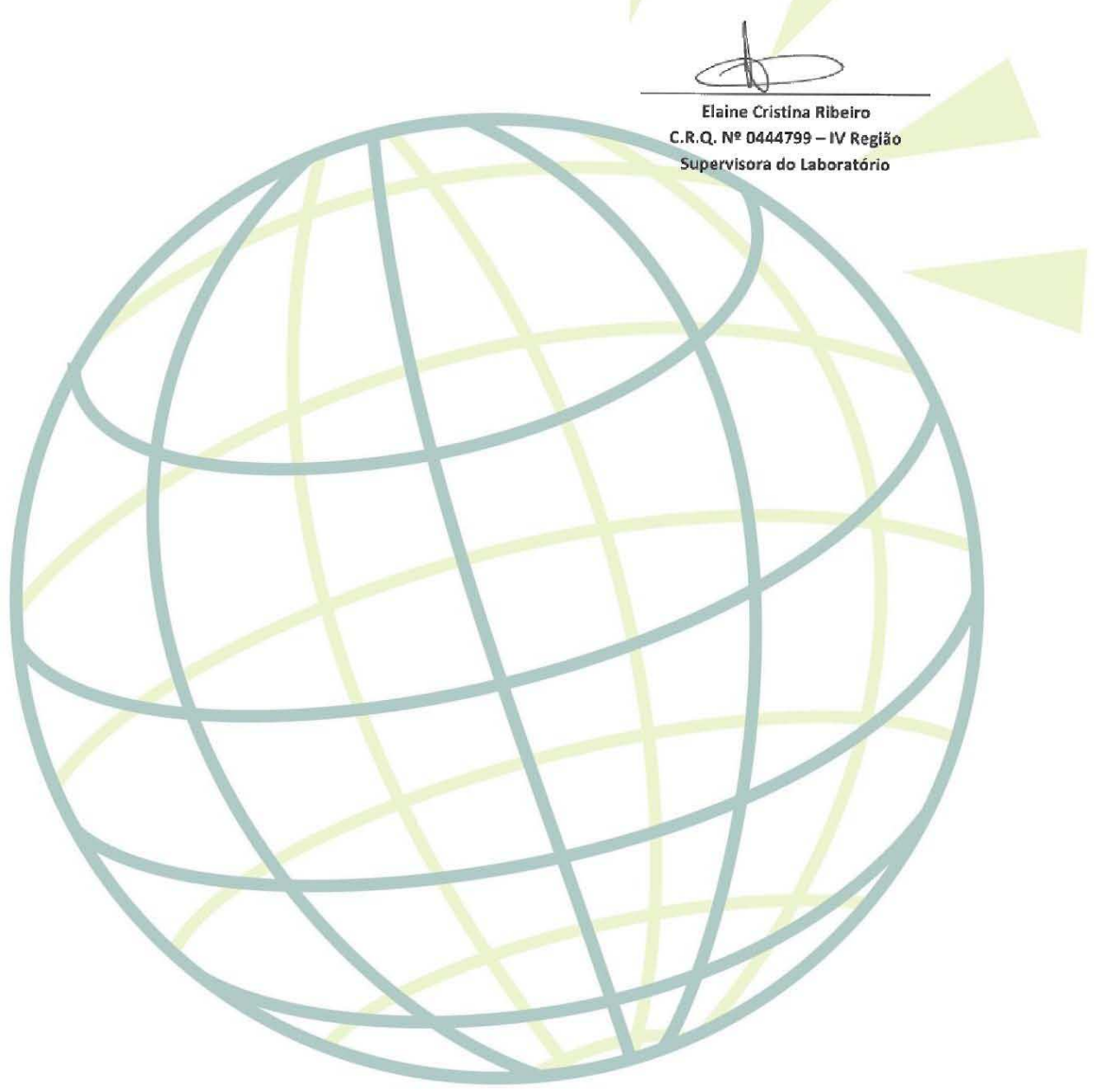

Página 4 de 4 / B.A. 1355/2013 - 1.0 lbiporã $\mathrm{N}^{\circ} 272$ 
Cotia - SP, Rua Itafarma, 88 Jardim do Rio Cotia - CEP 06715-795

Tel.: (11) 5097.2249 - Fax: (11) 5097.2240

e-mail: comercialsp@operatorlab.com.br

Volta Redonda - RJ, Av. Sete de

Setembro, 449 - Aterrado - CEP 27213-310

Tel.: (24) 3337.4220 - Fax: (24) 3337.9832

e-mail: comercialvr@operatorlab.com.br

$\begin{aligned} & \text { BOLETIM DE ANÁLISE N. }{ }^{\circ 1355 / 2013-1.0} \\
& \text { Processo Comercial N. }{ }^{\circ} 1709 / 2012-1\end{aligned}$
\begin{tabular}{|l|}
\hline DADOS Do CONTRATANTE \\
\hline Contratante: Escola Politécnica - Usp \\
\hline CNPJ/CPF: 08.495.832/0001-38 \\
\hline Endereço: Avenida Prof. Luciano Gualberto, 158 Trav 3 - - São Paulo - SP CEP: 05.508-010 \\
\hline Contato: Juliana Alencar Telefone: (11) \\
\hline
\end{tabular}

DADOS DO SOLICITANTE

Solicitante: Escola Politécnica - Usp

CNPJ/CPF: 08.495.832/0001-38

Endereço de coleta: Avenida Prof. Luciano Gualberto, 158 Trav 3 - - São Paulo - SP CEP: 05.508-010

Legislação ou norma: Sem Comparativo

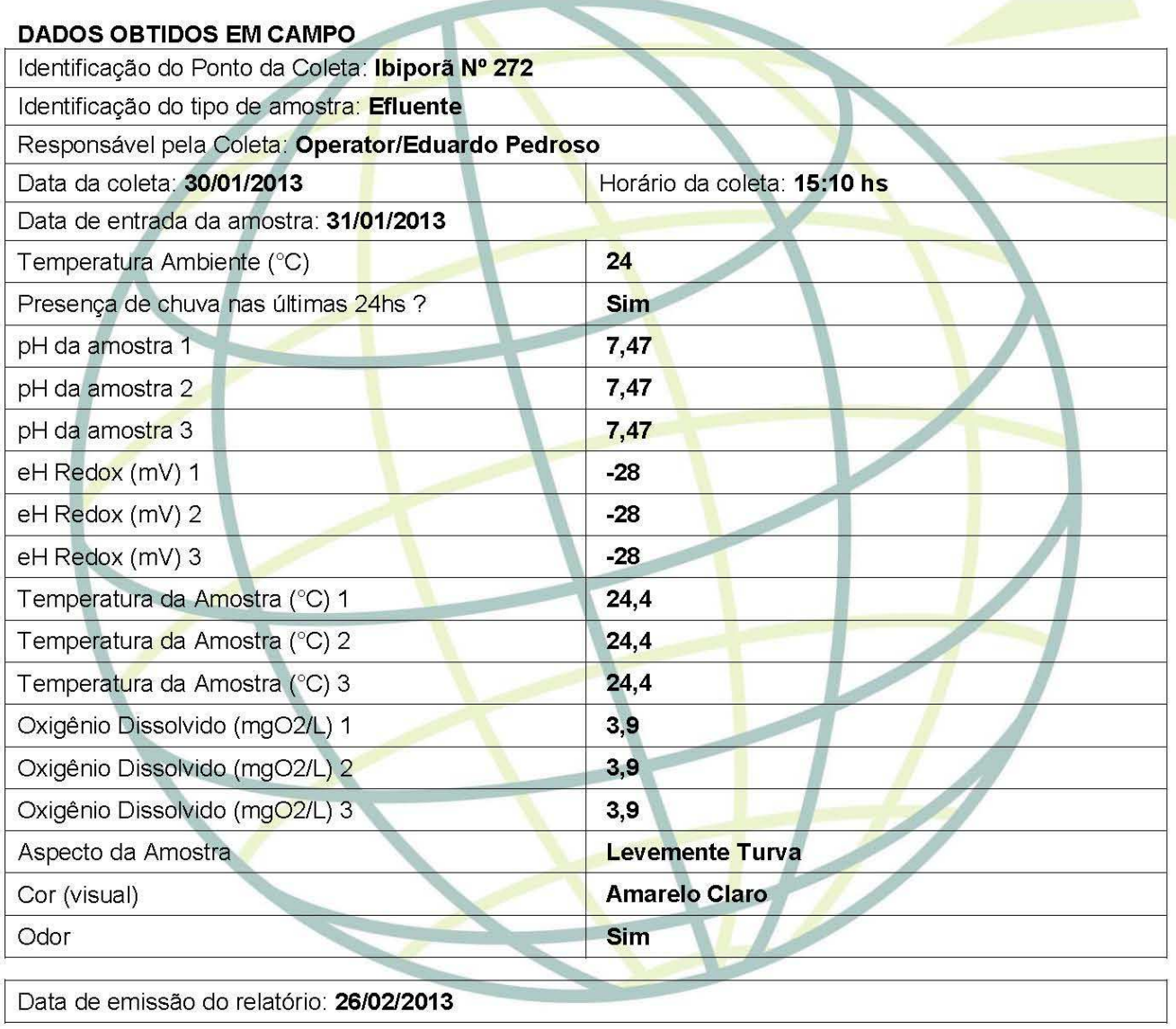

Página 1 de 2 / B.A. 1355/2013 - 1.0 Ibiporã No 272 


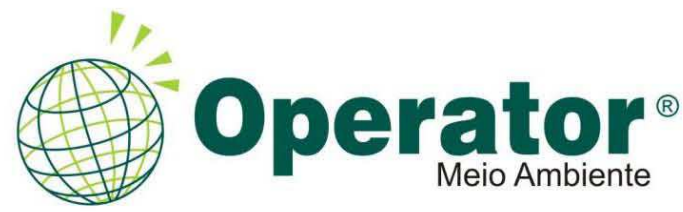

Cotia - SP, Rua Itafarma, 88

Jardim do Rio Cotia - CEP 06715-795

Tel.: (11) 5097.2249 - Fax: (11) 5097.2240

e-mail: comercialsp@operatorlab.com.br

Volta Redonda - RJ, Av. Sete de

Setembro, 449 - Aterrado - CEP 27213-310

Tel.: (24) 3337.4220 - Fax: (24) 3337.9832

e-mail: comercialvr@operatorlab.com.br

\begin{tabular}{|c|c|c|c|c|c|c|}
\hline \multicolumn{7}{|c|}{ RESULTADOS ANALÍTICOS } \\
\hline \multicolumn{7}{|c|}{ PARÂMETROS A SEGUIR NÃO SÃO ACREDITADOS ISO/IEC ABNT NBR ISO/IEC 17025:2005 } \\
\hline \multicolumn{7}{|c|}{ Parâmetro } \\
\hline Parâmetros & Unidade & LQ & Resultados & $\begin{array}{c}\text { Incerteza } \\
( \pm)\end{array}$ & $\begin{array}{c}\text { Data de } \\
\text { Realização }\end{array}$ & м \\
\hline Nitrogênio Kjedahl Total & $\mathrm{mg} / \mathrm{L}$ & 0,08 & 1,65 & 0,01 & $13 / 02 / 2013$ & 52 \\
\hline
\end{tabular}

L.D - Limite de Detecção

L.Q- Limite de Quantificaçăo

(๔) Abaixo do Limite de Deteç̧ão

Notas:

(1) Os resultados referem-se somente a amostra analisada.

(2) Plano de Amostragem / identificação dos pontos a serem amostrados é de responsabilidade do cliente.

(3) Todas as análises foram realizadas dentro dos prazos de validade da amostra, conforme indicado nas normas: SMEWW 21 st Ed.; EPA; NBR; ASTM; CETESB; INEA e normas técnicas vigentes e descritas nas instruções operacionais padrão de Coleta e Preservação de Amostras da OPERATOR.

(4) Os dados brutos obtidos na execução das análises estão à disposição, podendo ser solicitado a qualquer momento.

(5) A interpretação dos resultados leva em consideração a incerteza de medição do ensaio.

(6) As incertezas apresentadas nos boletins de análise são referente à incerteza expandida dos métodos analíticos

M Métodos de Referência

52 Nitrogênio Kjeldahl Total: SMEWW 4500 - Norg B Macro-Kjeldahl Method // SMEWW 4500 NH3 - D - Ammonia-Selective Electrode Method

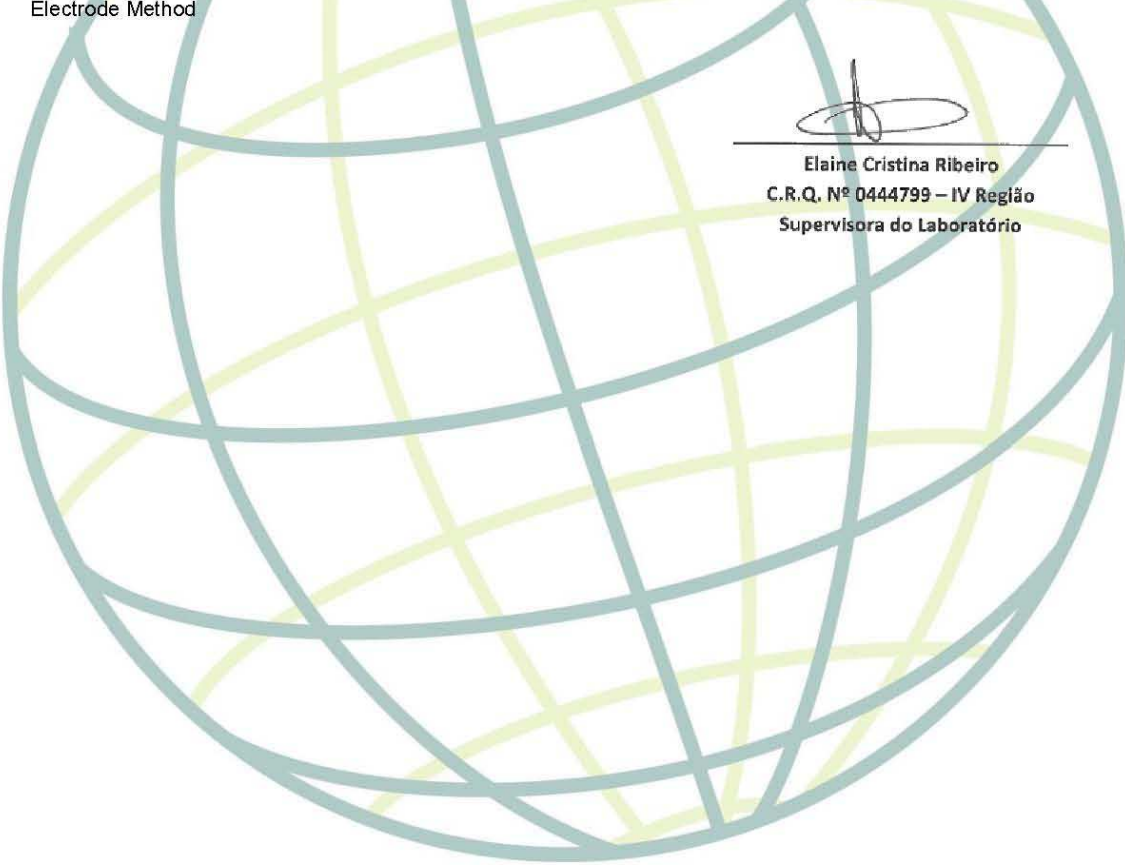

Página 2 de 2 / B.A. 1355/2013- 1.0 lbiporã $\mathrm{N}^{\circ} 272$ 


\section{Operattor}

Cotia - SP, Rua Itafarma, 88

Jardim do Rio Cotia - CEP 06715-795

Tel.: (11) 5097.2249 - Fax: (11) 5097.2240

e-mail: comercialsp@operatorlab.com.br

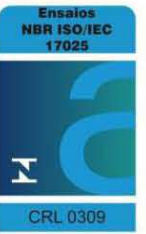

\begin{tabular}{|c|}
\hline $\begin{array}{l}\text { BOLETIM DE ANÁLISE N. }{ }^{\circ} \mathbf{1 3 5 6 / 2 0 1 3 - 1 . 0} \\
\text { Processo Comercial N. }{ }^{\circ} 1709 / 2012-1\end{array}$ \\
\hline DADOS DO CONTRATANTE \\
\hline Contratante: Escola Politécnica - Usp \\
\hline CNPJ/CPF: 08.495.832/0001-38 \\
\hline Endereço: Avenida Prof. Luciano Gualberto, 158 Trav 3 - - São Paulo - SP CEP: 05.508-010 \\
\hline
\end{tabular}

DADOS DO SOLICITANTE

Solicitante: Escola Politécnica - Usp

CNPJ/CPF: 08.495.832/0001-38

Endereço de coleta: Avenida Prof. Luciano Gualberto, 158 Trav 3 - - São Paulo - SP CEP: 05.508-010

Legislação ou norma: Sem Comparativo

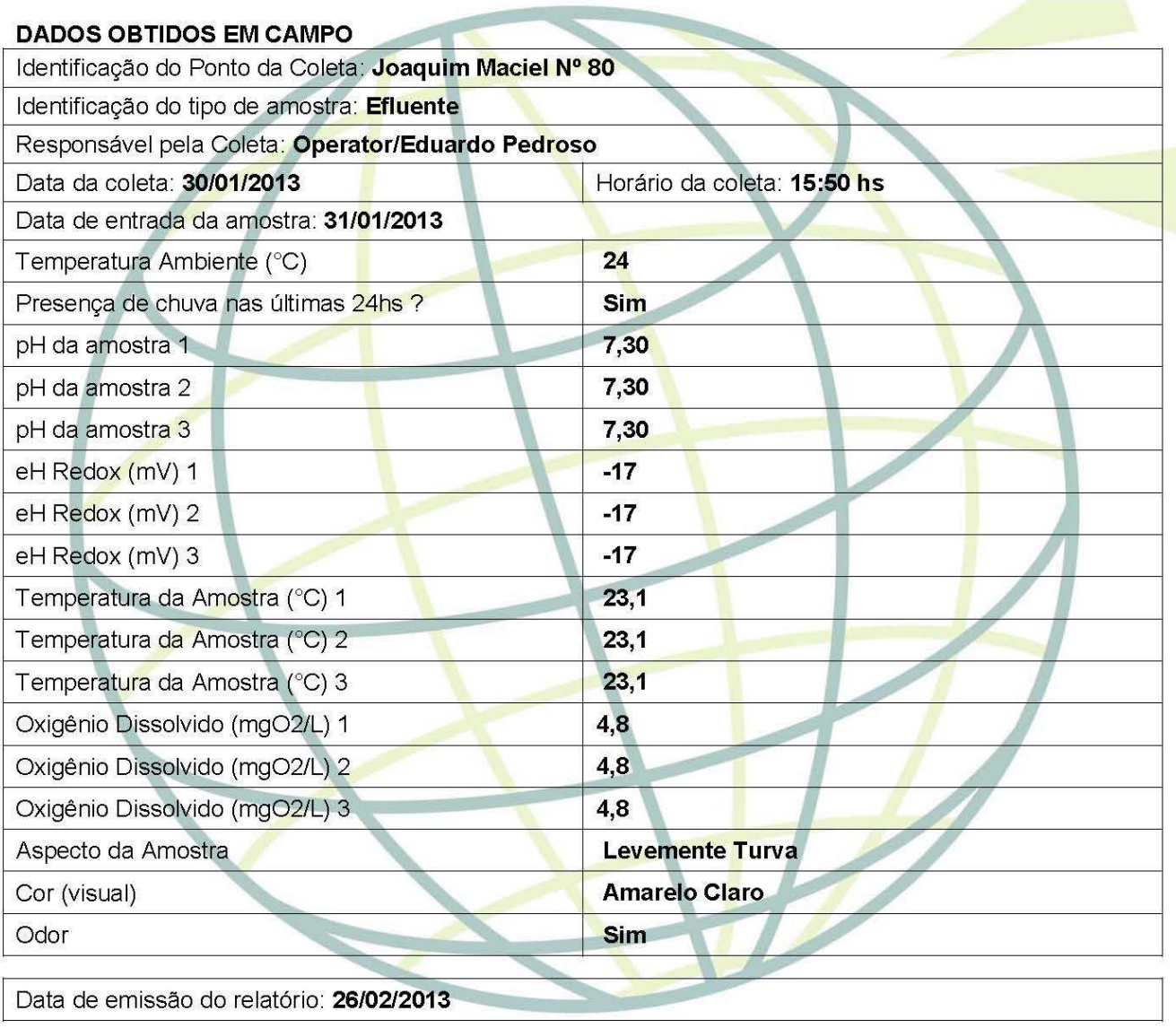

Página 1 de 4 / B.A. 1356/2013- 1.0 Joaquim Maciel $N^{\circ} 80$ 
Cotia - SP, Rua Itafarma, 88 Jardim do Rio Cotia - CEP 06715-795 Tel.: (11) 5097.2249 - Fax: (11) 5097.2240 e-mail: comercialsp@operatorlab.com.br

\begin{tabular}{|c|c|c|c|c|c|c|}
\hline \multicolumn{7}{|c|}{ RESULTADOS ANALÍTICOS } \\
\hline \multicolumn{7}{|c|}{ PARÂMETROS ACREDITADOS ISO/IEC ABNT NBR ISO/IEC 17025:2005 } \\
\hline \multicolumn{7}{|c|}{ Parâmetro } \\
\hline Parâmetros & Unidade & LQ & Resultados & $\begin{array}{l}\text { Incerteza } \\
( \pm)\end{array}$ & $\begin{array}{c}\text { Data de } \\
\text { Realizaçăo }\end{array}$ & m \\
\hline DBO & $\mathrm{mg} / \mathrm{L}$ & 2 & 15 & 1 & $31 / 01 / 2013$ & 61 \\
\hline Oxigênio Dissolvido & $\mathrm{mg} / \mathrm{L}$ & 0,50 & 4,80 & 0,001 & 05/02/2013 & 110 \\
\hline Turbidez & NTU & 0,03 & 9,43 & 0,56 & $31 / 01 / 2013$ & 60 \\
\hline $\mathrm{pH}$ & --- & 0,10 & 7,30 & 0,03 & $31 / 01 / 2013$ & 30 \\
\hline Sólidos Dissolvidos Totais & $\mathrm{mg} / \mathrm{L}$ & 5 & 43 & 1 & $01 / 02 / 2013$ & 64 \\
\hline Nitrato & $\mathrm{mg} / \mathrm{L}$ & 0,07 & 1,78 & 0,009 & $31 / 01 / 2013$ & 35 \\
\hline Nitrogênio Amoniacal & $\mathrm{mg} / \mathrm{L}$ & 0,08 & $<0,08$ & -- & $13 / 02 / 2013$ & 50 \\
\hline Alcalinidade Total & $\mathrm{mg} / \mathrm{L}$ & 5 & 56 & 5 & $05 / 02 / 2013$ & 32 \\
\hline Temperatura & ${ }^{\circ} \mathrm{C}$ & 1,0 & 23,1 & 0,15 & $05 / 02 / 2013$ & 58 \\
\hline Fósforo Total & $\mathrm{mg} / \mathrm{L}$ & 3,6000 & $<3,6000$ & -- & $26 / 02 / 2013$ & 75 \\
\hline $\mathrm{DQO}$ & $\mathrm{mg} / \mathrm{L}$ & 5 & 38 & 1 & $04 / 02 / 2013$ & 62 \\
\hline Alumínio Dissolvido & $\mathrm{mg} / \mathrm{L}$ & 0,005 & 0,027 & 0,0005 & $26 / 02 / 2013$ & 75 \\
\hline Cobre Dissolvido & $\mathrm{mg} / \mathrm{L}$ & 0,0017 & $<0,0017$ & 0,00005 & $26 / 02 / 2013$ & 75 \\
\hline Ferro Dissolvido & $\mathrm{mg} / \mathrm{L}$ & 0,002 & 0,206 & 0,0005 & $26 / 02 / 2013$ & 75 \\
\hline Mercúrio Total & $\mathrm{mg} / \mathrm{L}$ & 0,00010 & $<0,00010$ & 0,00003 & $26 / 02 / 2013$ & 75 \\
\hline Antimônio & $\mathrm{mg} / \mathrm{L}$ & 0,002 & $<0,002$ & 0,0005 & $26 / 02 / 2013$ & 75 \\
\hline Arsênio Total & $\mathrm{mg} / \mathrm{L}$ & 0,002 & $<0,002$ & 0,0005 & $26 / 02 / 2013$ & 75 \\
\hline Bário Total & $\mathrm{mg} / \mathrm{L}$ & 0,0017 & 0,0629 & 0,00005 & $26 / 02 / 2013$ & 75 \\
\hline Berilio Total & $\mathrm{mg} / \mathrm{L}$ & 0,006 & $<0,006$ & 0,0003 & $26 / 02 / 2013$ & 75 \\
\hline Boro Total & $\mathrm{mg} / \mathrm{L}$ & 0,052 & $<0,052$ & 0,0053 & $26 / 02 / 2013$ & 75 \\
\hline Cádmio Total & $\mathrm{mg} / \mathrm{L}$ & 0,0017 & $<0,0017$ & 0,00005 & $26 / 02 / 2013$ & 75 \\
\hline Chumbo Total & $\mathrm{mg} / \mathrm{L}$ & 0,002 & 0,006 & 0,0005 & $26 / 02 / 2013$ & 75 \\
\hline Cobalto Total & $\mathrm{mg} / \mathrm{L}$ & 0,002 & 0,016 & 0,0005 & $26 / 02 / 2013$ & 75 \\
\hline Cromo Total & $\mathrm{mg} / \mathrm{L}$ & 0,006 & $<0,006$ & 0,0015 & $26 / 02 / 2013$ & 75 \\
\hline Lítio Total & $\mathrm{mg} / \mathrm{L}$ & 0,027 & $<0,027$ & 0,0125 & $26 / 02 / 2013$ & 75 \\
\hline Manganês Total & $\mathrm{mg} / \mathrm{L}$ & 0,003 & 0,254 & 0,0005 & $26 / 02 / 2013$ & 75 \\
\hline Niquel Total & $\mathrm{mg} / \mathrm{L}$ & 0,0017 & $<0,0017$ & 0,00005 & $26 / 02 / 2013$ & 75 \\
\hline Prata Total & $\mathrm{mg} / \mathrm{L}$ & 0,00010 & $<0,00010$ & 0,00004 & $26 / 02 / 2013$ & 75 \\
\hline Selênio Total & $\mathrm{mg} / \mathrm{L}$ & 0,003 & $<0,003$ & 0,0005 & $26 / 02 / 2013$ & 75 \\
\hline Vanádio Total & $\mathrm{mg} / \mathrm{L}$ & 0,004 & $<0,004$ & 0,0010 & $26 / 02 / 2013$ & 75 \\
\hline Zinco Total & $\mathrm{mg} / \mathrm{L}$ & 0,0011 & 0,0342 & 0,0003 & $26 / 02 / 2013$ & 75 \\
\hline 2-Clorofenol & $\mu g / L$ & 0,010 & $<0,010$ & 0,001 & $04 / 02 / 2013$ & 12 \\
\hline 1,2-Dicloroetano & $\mu \mathrm{g} / \mathrm{L}$ & 2,00 & $<2,00$ & 0,20 & $31 / 01 / 2013$ & 128 \\
\hline 1,1-Dicloroeteno & $\mu \mathrm{g} / \mathrm{L}$ & 2,00 & $<2,00$ & 0,20 & $31 / 01 / 2013$ & 128 \\
\hline
\end{tabular}


Cotia - SP, Rua Itafarma, 88

Jardim do Rio Cotia - CEP 06715-795

Tel.: (11) 5097.2249 - Fax: (11) 5097.2240

e-mail: comercialsp@operatorlab.com.br

Parâmetro
\begin{tabular}{|l|c|c|c|c|c|c|}
\hline Parâmetros & Unidade & LQ & Resultados & $\begin{array}{c}\text { Incerteza } \\
(\mathbf{\pm})\end{array}$ & $\begin{array}{c}\text { Data de } \\
\text { Realização }\end{array}$ & \begin{tabular}{c} 
M \\
\hline Estireno
\end{tabular} \\
\hline Tetracloreto de Carbono & 2,00 & $<\mathbf{2 , 0 0}$ & 0,20 & $31 / 01 / 2013$ & 128 \\
\hline Tetracloroeteno & $\mu \mathrm{g} / \mathrm{L}$ & 2,00 & $<\mathbf{2 , 0 0}$ & 0,20 & $31 / 01 / 2013$ & 128 \\
\hline Triclorobenzenos & $\mu \mathrm{g} / \mathrm{L}$ & 2,00 & $<\mathbf{2 , 0 0}$ & 0,20 & $31 / 01 / 2013$ & 128 \\
\hline Tricloroeteno & $\mu \mathrm{g} / \mathrm{L}$ & 2,00 & $<\mathbf{2 , 0 0}$ & 0,20 & $31 / 01 / 2013$ & 128 \\
\hline Benzeno & $\mu \mathrm{g} / \mathrm{L}$ & 2,00 & $<\mathbf{2 , 0 0}$ & 0,20 & $31 / 01 / 2013$ & 128 \\
\hline Etilbenzeno & $\mu \mathrm{g} / \mathrm{L}$ & 2,00 & $<\mathbf{2 , 0 0}$ & 0,20 & $31 / 01 / 2013$ & 128 \\
\hline Tolueno & $\mu \mathrm{g} / \mathrm{L}$ & 2,00 & $<\mathbf{2 , 0 0}$ & 0,20 & $31 / 01 / 2013$ & 128 \\
\hline Xilenos & $\mu \mathrm{g} / \mathrm{L}$ & 2,00 & $<\mathbf{2 , 0 0}$ & 0,20 & $31 / 01 / 2013$ & 128 \\
\hline Diclorometano & $\mu \mathrm{g} / \mathrm{L}$ & 2,00 & $<\mathbf{2 , 0 0}$ & 0,20 & $31 / 01 / 2013$ & 128 \\
\hline Oleos e Graxas & $\mu \mathrm{g} / \mathrm{L}$ & 2,00 & $<\mathbf{2 , 0 0}$ & 0,20 & $31 / 01 / 2013$ & 128 \\
\hline & $\mathrm{mg} / \mathrm{L}$ & 5 & $\mathbf{1 1}$ & 0,6 & $04 / 02 / 2013$ & 46 \\
\hline
\end{tabular}

RECUPERAÇÃO DOS SURROGATES

1356/2013 - Efluente - Joaquim Maciel No 80

\begin{tabular}{|l|c|c|c|}
\hline Parâmetros & Unidade & LQ & Resultado \\
\hline Itrio & $\%$ & 0,1 & $\mathbf{7 6 , 3}$ \\
\hline p-Bromofluorbenzeno & $\%$ & 0,05 & $\mathbf{1 0 9 , 7 3}$ \\
\hline Tolueno-d8 & $\%$ & 0,05 & $\mathbf{1 0 5 , 2 1}$ \\
\hline 2-Fluorobifenil & $\%$ & 0,05 & 79,00 \\
\hline p-Terfenil d14 & $\%$ & 0,05 & 78,78 \\
\hline
\end{tabular}

L.D - Limite de Detecção

L.Q- Limite de Quantificação

(द) Abaixo do Limite de Deteç̧ão

Notas:

(1) Os resultados referem-se somente a amostra analisada.

(2) Plano de Amostragem / identificação dos pontos a serem amostrados é de responsabilidade do cliente.

(3) Todas as análises foram realizadas dentro dos prazos de validade da amostra, conforme indicado nas normas: SMEMW 21 st Ed.; EPA; NBR; ASTM; CETESB; INEA e normas técnicas vigentes e descritas nas instruções operacionais padrão de Coleta e Preservação de Amostras da OPERATOR.

(4) Os dados brutos obtidos na execução das análises estão à disposição, podendo ser solicitado a qualquer momento.

(5) A interpretação dos resultados leva em consideração a incerteza de medição do ensaio.

(6) As incertezas apresentadas nos boletins de análise são referente à incerteza expandida dos métodos analíticos.

\section{Métodos de Referência}

USEPA SW 846 - Method 8270 D - Semivolatile Organic Compounds by CG/MS rev 04 - Fev 2007

SM22 4500-H B - Eletrometric Method

Alcalinidade: SMEWW 21th Ed. 2320 - Alkalinity

Ânions: USEPA SW 846 - Method 300.1 - Determination of Inorganic Anions in Drinking Water by lon Chromatography

Oleos e Graxas: SMEWW 5520 - Oil and Grease 


\section{7

Cotia - SP Rua Itafarma, 88

Jardim do Rio Cotia - CEP 06715-795

Tel.: (11) 5097.2249 - Fax: (11) 5097.2240

e-mail: comercialsp@operatorlab.com.br

50 SMWW 22nd ed., 2012 - Part 4500 D - Ammonia-Selective Electrode Method

58 Temperatura: Leitura direta com Termohigrômetro

60 Turbidez: SMEWW 21th Ed. 2130 B - Nephelometric Method

61 DBO: SMEWw 21th Ed. 5210 B. Biochemical Oxygen Demand (BOD)

62 DQO: SMEWW 21th Ed. 5220 - D - Closed Reflux, Colorimetric Method

64 Sólidos Dissolvidos: SWEMM 2540 - C - Total Dissolved Solids Dried at $180^{\circ} \mathrm{C}$

75 USEPA SW 846 - Method 6010 C - Inductivily Coupled Plasma Atomic Emission Espectrometry

110 Oxigênio Dissolvido: SMEMN 4500 - O - Oxygen (Dissolved)

USEPA SW 846 - Method $8021 \mathrm{~B}$ - Aromatic and halogenated volatiles by gas chromatography using photo ionization and/or eletrolytic conductivity detectors

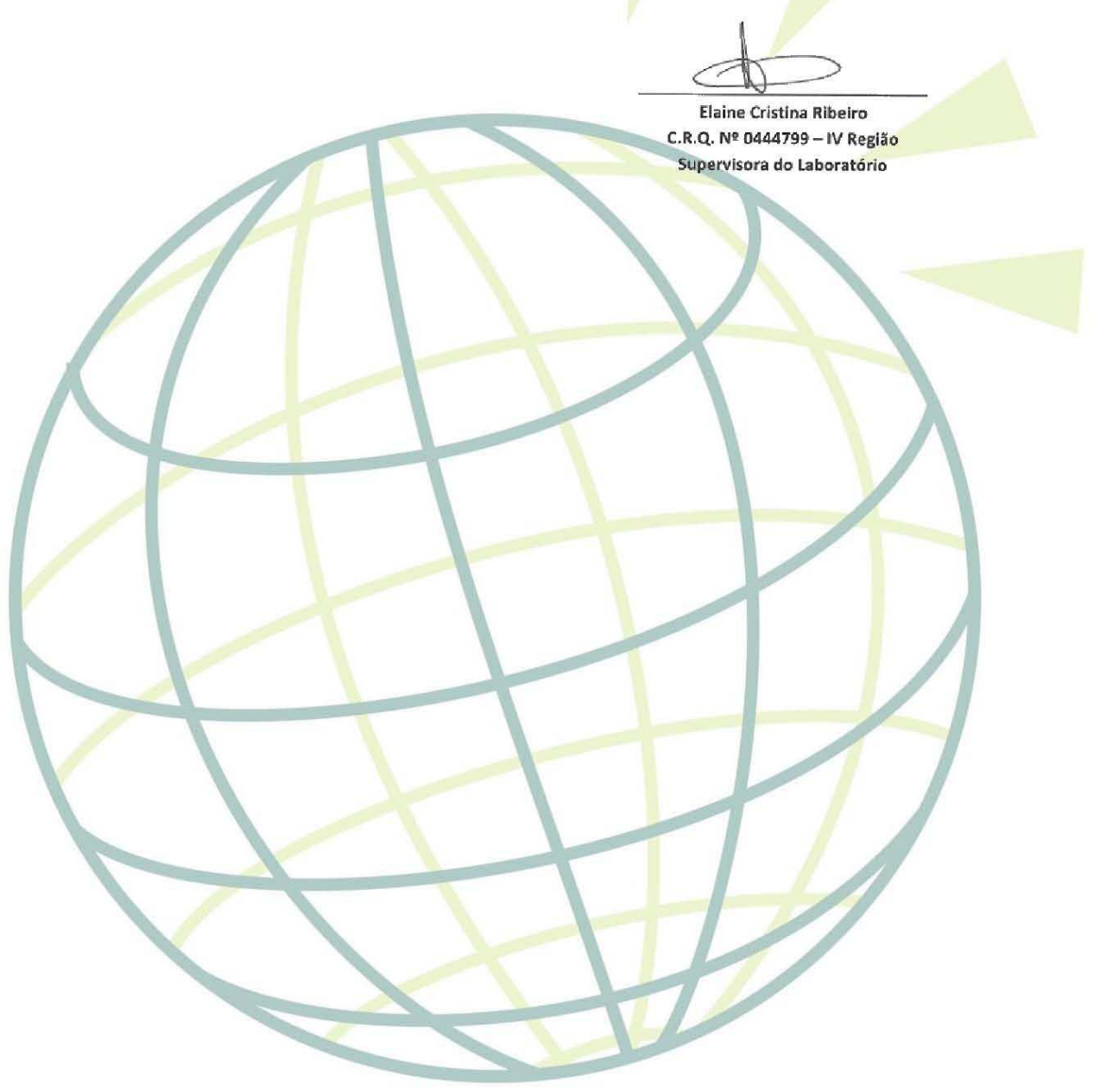

Página 4 de 4 / B.A. 1356/2013 - 1.0 Joaquim Maciel № 80 
Cotia - SP, Rua Itafarma, 88 Jardim do Rio Cotia - CEP 06715-795

Tel.: (11) 5097.2249 - Fax: (11) 5097.2240

e-mail: comercialsp@operatorlab.com.br

Volta Redonda - RJ, Av. Sete de

Setembro, 449 - Aterrado - CEP 27213-310

Tel.: (24) 3337.4220 - Fax: (24) 3337.9832

e-mail: comercialvr@operatorlab.com.br

$\begin{aligned} & \text { BOLETIM DE ANÁLISE N. }{ }^{\circ 1356 / 2013-1.0} \\
& \text { Processo Comercial N. }{ }^{\circ} 1709 / 2012-1\end{aligned}$
\begin{tabular}{|l|}
\hline DADOS Do CONTRATANTE \\
\hline Contratante: Escola Politécnica - Usp \\
\hline CNPJ/CPF: 08.495.832/0001-38 \\
\hline Endereço: Avenida Prof. Luciano Gualberto, 158 Trav 3 - - São Paulo - SP CEP: 05.508-010 \\
\hline Contato: Juliana Alencar Telefone: (11) \\
\hline
\end{tabular}

DADOS DO SOLICITANTE

Solicitante: Escola Politécnica - Usp

CNPJ/CPF: 08.495.832/0001-38

Endereço de coleta: Avenida Prof. Luciano Gualberto, 158 Trav 3 - - São Paulo - SP CEP: 05.508-010

Legislação ou norma: Sem Comparativo

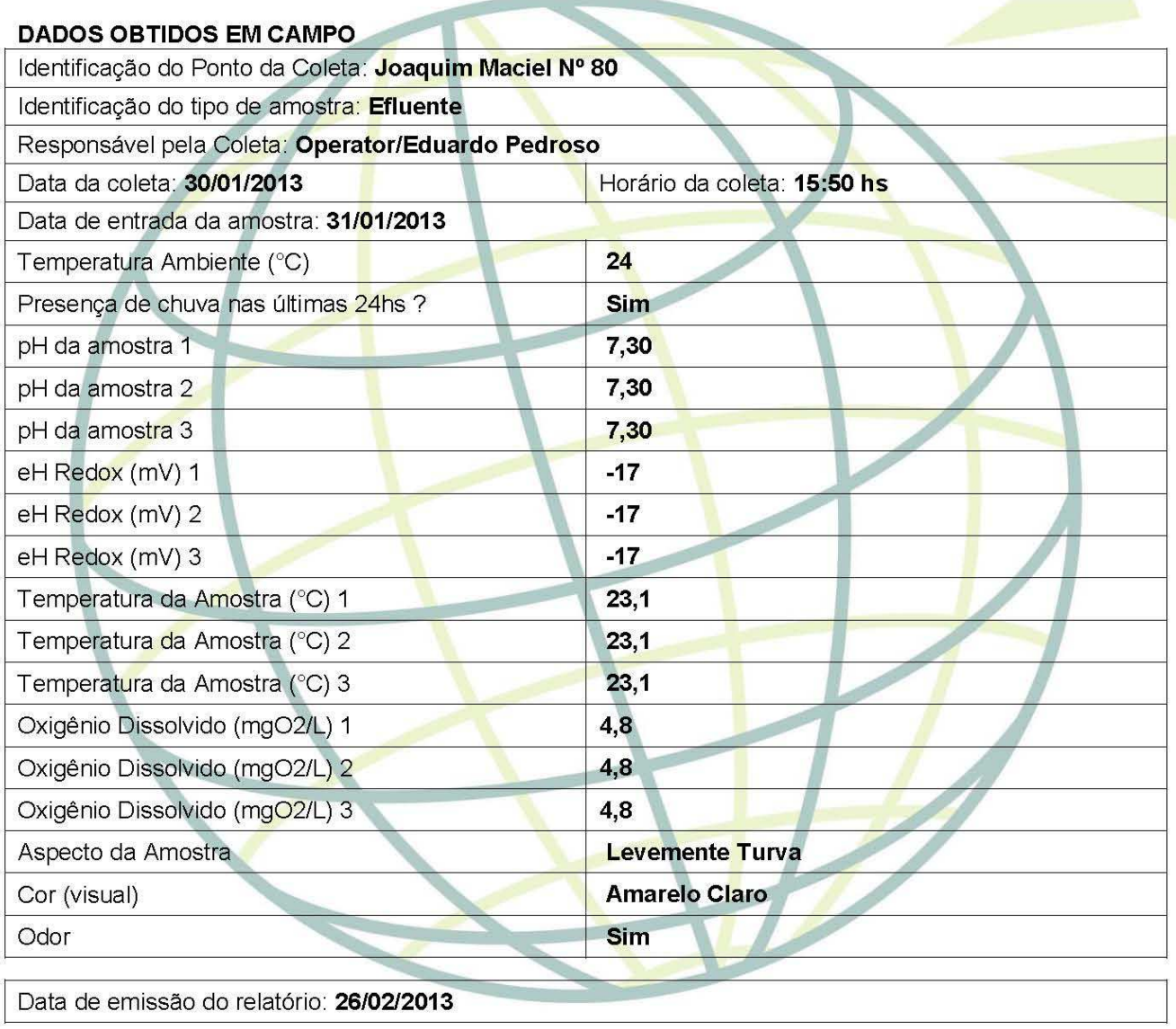

Página 1 de 2 / B.A. 1356/2013- 1.0 Joaquim Maciel $N^{\circ} 80$ 


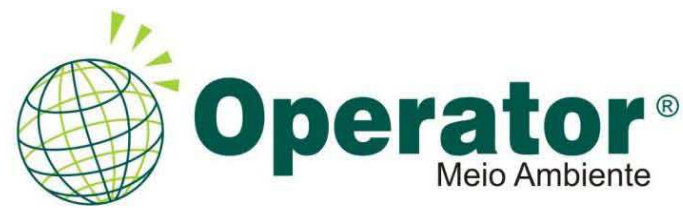

Cotia - SP, Rua Itafarma, 88

Jardim do Rio Cotia - CEP 06715-795

Tel.: (11) 5097.2249 - Fax: (11) 5097.2240

e-mail: comercialsp@operatorlab.com.br

Volta Redonda - RJ, Av. Sete de

Setembro, 449 - Aterrado - CEP 27213-310

Tel.: (24) 3337.4220 - Fax: (24) 3337.9832

e-mail: comercialvr@operatorlab.com.br

\begin{tabular}{|c|c|c|c|c|c|c|}
\hline \multicolumn{7}{|c|}{ RESULTADOS ANALÍTICOS } \\
\hline \multicolumn{7}{|c|}{ PARÂMETROS A SEGUIR NÃO SÃO ACREDITADOS ISO/IEC ABNT NBR ISO/IEC 17025:2005 } \\
\hline \multicolumn{7}{|c|}{ Parâmetro } \\
\hline Parâmetros & Unidade & LQ & Resultados & $\begin{array}{c}\text { Incerteza } \\
( \pm)\end{array}$ & $\begin{array}{c}\text { Data de } \\
\text { Realização }\end{array}$ & м \\
\hline Nitrogênio Kjedahl Total & $\mathrm{mg} / \mathrm{L}$ & 0,08 & $<0,08$ & 0,01 & $13 / 02 / 2013$ & 52 \\
\hline
\end{tabular}

L.D - Limite de Detecção

L.Q- Limite de Quantificaçăo

(๔) Abaixo do Limite de Deteç̧ão

Notas:

(1) Os resultados referem-se somente a amostra analisada.

(2) Plano de Amostragem / identificação dos pontos a serem amostrados é de responsabilidade do cliente.

(3) Todas as análises foram realizadas dentro dos prazos de validade da amostra, conforme indicado nas normas: SMEWW 21 st Ed.; EPA; NBR; ASTM; CETESB; INEA e normas técnicas vigentes e descritas nas instruções operacionais padrão de Coleta e Preservação de Amostras da OPERATOR.

(4) Os dados brutos obtidos na execução das análises estão à disposição, podendo ser solicitado a qualquer momento.

(5) A interpretação dos resultados leva em consideração a incerteza de medição do ensaio.

(6) As incertezas apresentadas nos boletins de análise são referente à incerteza expandida dos métodos analíticos

M Métodos de Referência

52 Nitrogênio Kjeldahl Total: SMEWW 4500 - Norg B Macro-Kjeldahl Method // SMEWW 4500 NH3 - D - Ammonia-Selective 52 Electrode Method

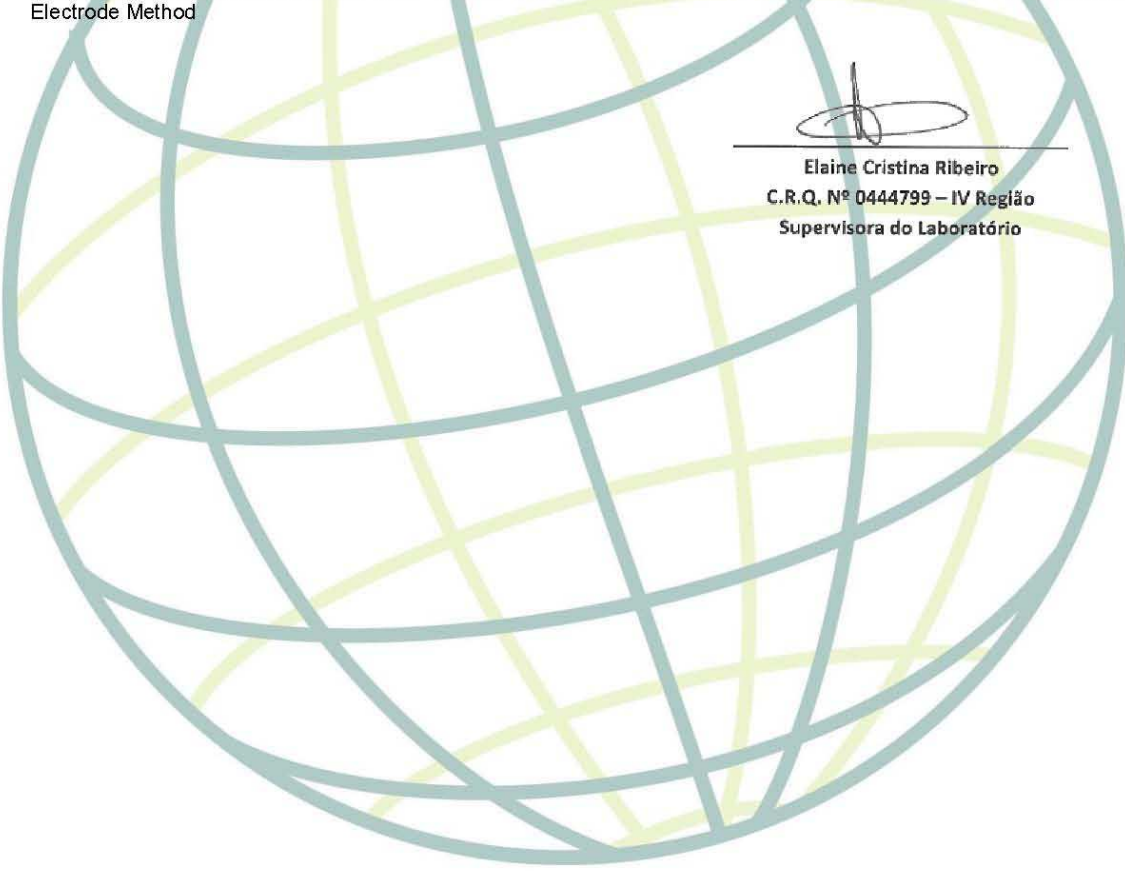

Página 2 de 2 / B.A. 1356/2013- 1.0 Joaquim Maciel $\mathrm{N}^{\circ} 80$ 